
REYNOLDS HISTORICAL GENEALOGY COLLECTION 
J ALLEN COUNTY PUBLIC LIBRARY L 




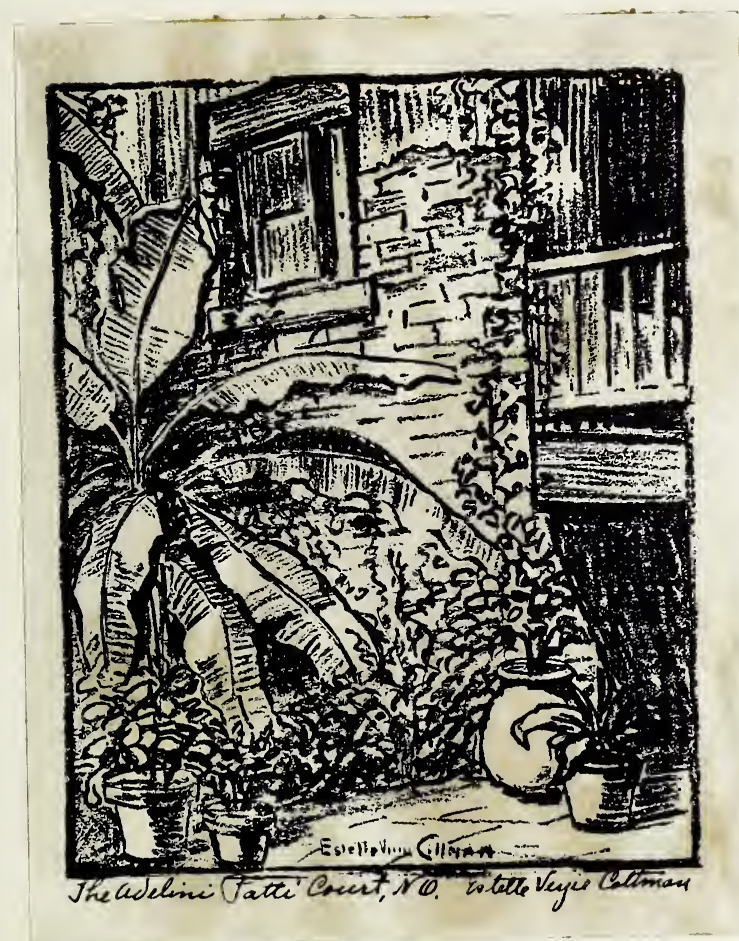


Digitized by the Internet Archive in 2016 


\section{History of Louisiana}

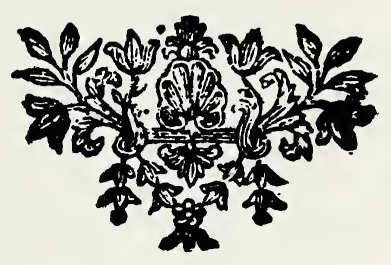





\section{T H E}

$\begin{array}{lllllll}H & I & S & T & O & R & Y\end{array}$

$O B$

L O U I S I A N A,

O R O F

THE WESTERN PARTS

O F

VIRGINIA AND CAROLINA:

Containing a DEsCription of the

Countries that lie on both Sides of the River Missisipp1:

With an Account of the

SETTLEMENTS, INHABITANTS, SOIL, CLIMATE, AND PRODUCTS.

Tranflated from the FRENCH

Of M. LE PAGE DU PRATZ;

With fome Notes and Obfervations relating to our Colonies.

A NE W E D I T I O N.

\section{O N D O N,}

Printed for T. Becket, Corner of the Adelphi, in the Strand. 
Printed in the United States of America by the Pelican Press, Inc. -:- New Orleans 


\section{$625+50$}

\section{NOTE}

This edition of Le Page Du Pratz' History of Louisiana, limited to 600 copies, is the first edition of this celebrated work printed in the United States. The title page used here is reproduced from the English edition of 1774. Included is a much-needed index not found in the English edition.

J. S. W. Harmanson, Publisher, 333 Royal St., New Orleans 



\section{For e word}

Antoine Simon Le Page Du Pratz was a Dutchman, as his birth in Holland about 1695 apparently proves. He died in 1775 , just where available records do not tell us, but the probabilities are that he died in France, for it is said he entered the French Army, serving with the Dragoons, and saw service in Germany. While there is some speculation about all the foregoing, there can be no speculation about the statement that on May 25, 1718 he left La Rochelle, France, in one of three ships bound for a place called Louisiana.

For M. Le Page tells us about this in a three-volume work he wrote called, Histoire de la Louisiane, recognized as the authority to be consulted by all who have written on the early history of New Orleans and the Louisiana province.

Le Page, who arrived in Louisiana August 25, 1718, three months after leaving La Rochelle, spent four months at Dauphin Island before he and his men made their way to Bayou St. John where he set up a plantation. He had at last reached New Orleans, which he correctly states, "existed only in name," and had to occupy an old lodge once used by an Acolapissa Indian. The young settler, he was only about 23 at the time, after arranging his shelter tells us: "A few days afterwards I purchased from a neighbour a native female slave, so as to have a woman to cook for us. My slave and I could not speak each other's language; but I made myself understood by means of signs." This slave, a girl of the Chitimacha tribe, remained with Le Page for years, and one draws the inference that she was possessed of a vigorous personality, and was not devoid of charm or bravery. Le Page writes that when frightened by an alligator approaching his camp fire, he ran to the lodge for his gun. However, the Indian girl calmly picked up a stick and hammered the 'gator so lustily on its nose that it retreated. As Le Page arrived with his gun, ready to shoot "the monster," he tells us: "She began to smile, and said many things which I did not comprehend, but she made me understand by signs, that there was no occasion for a gun to kill such a beast." 
It is unfortunate, for the purpose of sociological study, that this Indian girl appears so infrequently in the many accounts Le Page has left us in his highly interesting studies of early Louisiana and its original inhabitants. He does not even tell us the Indian girl's name.

We are told that after living on the banks of Bayou St. John for about two years, he left for the bluff lands of the Natchez country. His Indian girl decided she would go with him, as she had relatives there. Hearing of her plan, her old father offered to buy her back from Le Page. The Chitimacha girl, however, refused to leave her master, whereupon, the Indian father performed a rite of his tribe, which made her the ward of the white man-a simple ceremony of joining hands.

Le Page spent eight years among the Natchez and what he wrote about them-their lives, their customs, their ceremonials - has been acknowledged to be the best and most accurate accounts we have of these original inhabitants of Louisiana. $\mathrm{He}$ has left us, in his splendid history, much information on the other. Indian tribes of the lower Mississippi River country.

Antoine Simon Le Page Du Pratz tells us he spent sixteen years in Louisiana before returning to France in 1734. They were years well spent-to judge by what he wrote.

As it was written and published in the French language, Le Page's history proved in many instances to be a tantalizing casket of historical treasure that could not be opened by those who had not mastered French. The original edition, published in Paris in 1758, a score of years after the author landed in New Orleans, was followed in 1763 by a two-volume edition in English, and eleven years later in 1774 , by a one-volume edition in English, entitled: "The History of Louisiana, or of the Western Parts of Virginia and Carolina." The texts in the English editions are identical.

Fortunately, early historians who could not read the French edition, were now able to read M. Le Page's accounts of his adventures in the New World. Unfortunately, especially for present day historians, the English editions have become increasingly rare-many libraries do not have them on their shelves. Therefore, the present re-publication fills a long-felt want. 
The English translation, with its added matter, is reproduced exactly as it was printed for T. Becket to be sold in his shop at the corner of the Adelphi in the Strand, London, 1774. Errors of grammar and spelling are not corrected. The only change is the modernizing of the old $s$ 's which look like $f$ 's.

The present edition is really two works in one, for the English translation did not include any of the original edition's many illustrations. The London books did have two folding maps, one of the Louisiana province, the other of the country about the mouths of the Mississippi River. Not only are these maps reproduced in the present work, but in addition, all the other illustrations, including the rare map of New Orleans, appearing in the original French edition, are included. These quaint engravings of the birds, the beasts, the flowers, the shrubs, the trees, fish, the deer and buffalo hunts, and the habits and customs of the Natchez Indians, add much to the value of the present re-publication. I have captioned them with present-day names of the flora and fauna.

Stanley Clisby ARThur.

(Mr. Arthur is a naturalist, historian and writer, and executive-director of the Louisiana State Museum.J. S. W. Harmanson, Publisher.) 


\section{CONTENTS}

Preface

B O O K I.

The Transactions of the French in Louisiana.

CHAP. I. Of the first Discovery and Settlement of Louisiana

CHAP. II. The Return of M. de St. Denis: His settling the Spaniards at the Assinaïs. His second Journey to Mexico, and Return from thence.

CHAP. III. Embarkation of eight hundred Men by the West-India Company to Louisiana. Arrival and Stay at Cape François. Arrival at the Isle Dauphine. Description of that Island.

CHAP. IV. The Author's Departure for his Grant. Description of the Places he passed through, as far as New Orleans

CHAP. V. The Author put in Possession of his Territory. His Resolution to go and settle among the Natchez......

CHAP. VI. The Voyage of the Author to Biloxi. Description of that Place. Settlement of Grants. The Author discovers two Copper Mines. His Return to the Natchez

CHAP. VII. First War with the Natchez. Cause of the War

CHAP. VIII. The Governor surprized the Natchez with seven hundred Men. Astonishing Cures performed by the Natives. The Author sends upwards of three hundred Simples to the Company

CHAP. IX. French Settlements, or Posts. Post at Mobile. The Mouths of the Missisippi. The Situation and Description of New Orleans 
CHAP. X. The Voyages of the French to the Missouris, Canzas, and Padoucas. The Settlements they in vain attempted to make in those Countries; with a Description of an extraordinary Phænomenon.............................

CHAP. XI. The War with the Chitimachas. The Conspiracy of the Negroes against the French. Their Execution

CHAP. XII. The War of the Natchez. Massacre of the French in 1729. Extirpation of the Natchez in 1730

CHAP. XIII. The War with the Chicasaws. The first Expedition by the River Mobile. The second by the Missisippi. The War with the Chactaws terminated by the Prudence of M. de Vaudreuil

CHAP. XIV. Reflections on what gives Occasion to Wars in Louisiana. The Means of avoiding Wars in that Province, as also the Manner of coming off with Advantage and little Expence in them

CHAP. XV. Pensacola taken by Surprize by the French. Retaken by the Spaniards. Again retaken by the French, and demolished

\section{B O O K II.}

Of the Country and its Products.

CHAP. I. Geographical Description of Louisiana. Its Climate

Description of the Lower Louisiana, and the Mouths of the Missisippi

CHAP. II. The Author's Journey in Louisiana, from the Natchez to the River St. Francis, and the Country of the Chicasaws

CHAP. III. The Nature of the Lands of Louisiana. The Lands on the Coast

CHAP. IV. Quality of the Lands above the Fork. A Quarry of Stone for building. High Lands to the East: Their vast Fertility. West Coast: West Lands : Saltpetre 
CHAP. V. Quality of the Lands of the Red River. Posts of Nachitoches. A Silver Mine. Lands of the Black River

CHAP. VI. A Brook of salt Water: Salt Lakes. Lands of the River of the Arkansas. Red-veined Marble: Slate: Plaster. Hunting the Buffalo. The dry Sandbanks in the Missisippi

CHAP. VII. The Lands of the River St. Francis. Mine of Marameg, and other Mines. A Lead Mine. A soft Stone, resembling Porphyry. Lands of the Missouri. The Lands North of the Wabache. The Lands of the Illinois. De La Mothe's Mine, and other Mines.

CHAP. VIII. Of the Agriculture, or Manner of cultivating, ordering, and manufacturing the Commodities that are proper Articles of Commerce. Of the Culture of Maiz, Rice, and other Fruits of the Country. Of the Silk Worm

CHAP. IX. Of Indigo, Tobacco, Cotton, Wax, Hops, and Saffron

CHAP. X. Of the Commerce that is, and may be carried on in Louisiana. Of the Commodities which that Province may furnish in Return for those of Europe. Of the Commerce of Louisiana with the Isles.

CHAP. XI. Of the Commerce with the Spaniards. The Commodities they bring to the Colony, if there is a Demand for them. Of such as may be given in Return, and may suit them. Reflections on the Commerce of this Province, and the great Advantages which the State and particular Persons may derive therefrom

Some Abstracts from the Historical Memoirs of Louisiana, by M. Dumont.

I. Of Tobacco, with the Way of cultivating and curing it 187

II. Of the Way of making Indigo

III. Of Tar; the Way of making it; and of making it into pitch 
IV. Of the Mines of Louisiana

Extract from a late French Writer, concerning the Importance of Louisiana to France.

B O O K III.

The Natural History of Louisiana.

CHAP. I. Of Corn and Pulse............................................. 201

CHAP. II. Of the Fruit Trees of Louisiana........................ 208

CHAP. III. Of Forest Trees ............................................ 215

CHAP. IV. Of Shrubs and Excrescences............................ 226

CHAP. V. Of Creeping Plants ..................................... 232

CHAP. VI. Of the Quadrupedes................................... 240

CHAP. VII. Of Birds and flying Insects.......................... 257

CHAP. VIII. Of Fishes and Shell-Fish ............................ 274

B O O K IV.

Of the Natives of Louisiana.

CHAP. I. The Origin of the Americans

279

CHAP. II. An Account of the several Nations of Louisiana

SECT. I. Of the Nations inhabiting on the East of the Missisippi

SECT. II. Of the Nations inhabiting on the West of the Missisippi

CHAP. III. A Description of the Natives of Louisiana; of their Manners and Customs, particularly those of the Natchez: Of their Language, their Religion, Ceremonies, Rulers, or Suns, Feasts, Marriages, \&c.

Sect. I. A Description of the Natives; the different Employments of the two Sexes; and their Manner of bringing up their Children

SEct. II. Of the Language, Government, Religion, Ceremonies, and Feasts of the Natives

SECT. III. Of their Marriages, and Distinction of Ranks 326 
SECT. IV. Of the Temples, Tombs, Burials, and other religious Ceremonies of the People of Louisiana.......... 331

SECT. V. Of the Arts and Manufactures of the Natives 340

SECT. VI. Of the Attire and Diversions of the Natives:

Of their Meals and Fastings............................................. 344

SECT. VII. Of the Indian Art of War............................. 350

CHAP. IV. Of the Negroes of Louisiana.............................. 357

SECT. I. Of the Choice of Negroes; of their Distempers, and the Manner of curing them.................................... 357

SECT. II. Of the Manner of governing the Negroes........ 361

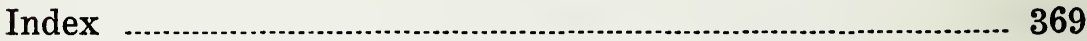




\section{List of Illustrations}

Page

Indian in Summer Time...................................................... 21

Indian in Winter Time..................................................... 31

Indian Woman and Daughter ............................................ 37

Plan of New Orleans, 1720............................................... 50

Beaver, Beaver lodge, Beaver dam.................................... 130

Indians of the North Leaving in the Winter with their Families for a Hunt ............................................. 142

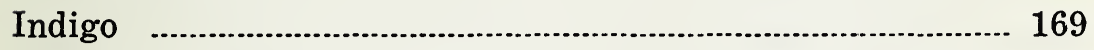

Cotton and Rice on the Stalk

Appalachean Beans. Sweet Potatoes .................................... 205

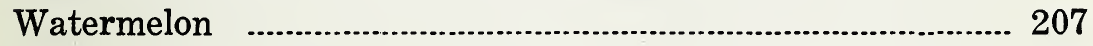

Pawpaw. Blue Whortle-berry ........................................... 211

Sweet Gum or Liquid-Amber ............................................... 214

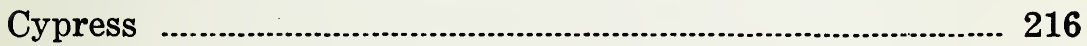

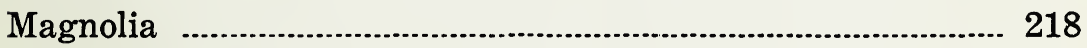

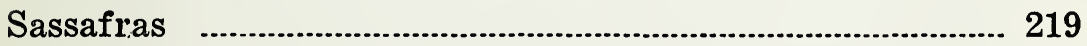

Myrtle Wax Tree. Vinegar Tree........................................... 221

Poplar ("Cotton Tree”) ........................................................ 223

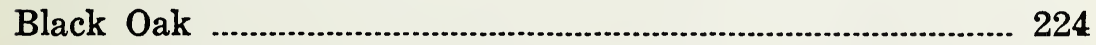

Linden or Bass Tree .......................................................... 225

Box Elder or Stink-wood Tree............................................... 227

Cassine or Yapon. Tootch-ache Tree or Prickly Ask.......... 228

Passion Thorn or Honey Locust. Bearded Creeper............. 229

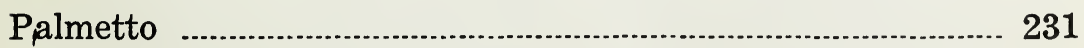




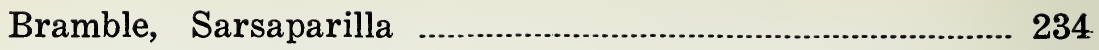

Rattlesnake Herb .............................................................. 236

Red Dye Plant. Flat Root ................................................. 238

Panther or Catamount. Bison or Buffalo ........................... 241

Indian Deer Hunt ................................................................ 243

Wild Cat. Opossum. Skunk …………………………...... 251

Alligator. Rattle Snake. Green Snake................................ 256

Pelican. Wood Stock ........................................................ 260

Flying Squirrel. Roseate Spoonbill. Snowy Heron............ 262

White Ibis. Tobacco Worm. Cock Roach ............................. 265

Cat Fish. Gar Fish. Spoonbill Catfish................................ 275

Indian Buffalo Hunt on Foot ................................................. 296.

Dance of the Natchez Indians............................................. 323

Burial of the Stung Serpent................................................ 338

Bringing the Pipe of Peace ............................................... 351

Torture of Prisoners. Plan of Fort.................................... 355 


\section{PREFAGE}

THE History of Louisiana, which we here present to the public, was wrote by a planter of sixteen years experience in that country, who had likewise the advantage of being overseer or director of the public plantations, both when they belonged to the company, and afterwards when they fell to the crown; by which means he had the best opportunities of knowing the nature of the soil and climate, and what they produce, or what improvements they are likely to admit of; a thing in which this nation is, without doubt, highly concerned and interested. And when our author published this history in 1758, he had likewise the advantage, not only of the accounts of $F$. Charlevoix, and others, but of the Historical Memoirs of Louisiana, published at Paris in 1753, by Mr. Dumont, an officer who resided two-and-twenty years in the country, and was personally concerned and acquainted with many of the transactions in it; from whom we have extracted some passages, to render this account more complete.

But whatever opportunities our author had of gaining a knowledge of his subject, it must be owned, that he made his accounts of it very perplexed. By endeavoring to take in every thing, he descends to many trifles; and by dwelling too long on a subject, he comes to render it obscure, by being prolix in things which hardly relate to what he treats of. He interrupts the thread of his discourse with private anecdotes, long harangues, and tedious narrations, which have little or no relation to the subject, and are of much less consequence to the reader. The want of method and order throughout the whole work is still more apparent; and that, joined to these digressions, renders his accounts, however just and interesting, so tedious and irksome to read, and at the same time so indistinct, that few seem to have reaped the benefit of them. For these reasons it was necessary to methodize the whole work; to abridge some parts of it; and to leave out many things that appear to be trifling. This we have endeavored to do in the translation, by reducing the whole work to four general heads or books; and 
by bringing the several subjects treated of, the accounts of which lie scattered up and down in different parts of the original, under these their proper heads; so that the connection between them, and the accounts of any one subject, may more easily appear.

This, it is presumed, will appear to be a subject of no small consequence and importance to this nation, especially at this time. The countries here treated of, have not only by right always belonged to Great-Britain, but part of them is now acknowledged to it by the former usurpers: and it is to be hoped, that the nation may now reap some advantages from those countries, on which it has expended so many millions; which there is no more likely way to do, than by making them better known in the first place, and by learning from the experience of others, what they do or are likely to produce, that may turn to account to the nation.

It has been generally suspected, that this nation has suffered much, from the want of a due knowledge of her dominions in America, which we should endeavor to prevent for the future. If that may be said of any part of America, it certainly may of those countries, which have been called by the French Louisiana. They have not only included under that name all the western parts of Virginia and Carolina; and thereby imagined, that they had, from this nominal title, a just right to those antient dominions of the crown of Britain: but what is of worse consequence perhaps, they have equally deceived and imposed upon many, by the extravagant hopes and unreasonable expectations they had formed to themselves, of the vast advantages they were to reap from those countries, as soon as they had usurped them; which when they came to be disappointed in, they ran from one extreme to another, and condemned the country as good for nothing, because it did not answer the extravagant hopes they had conceived of it; and we seem to be misled by their prejudices, and to be drawn into mistakes by their artifice or folly. Because the Missisippi scheme failed in 1719, every other reasonable scheme of improving that country, and of reaping any advantage from it, must do the same. It is to wipe off these prejudices, that the following account of these countries, which appears to be both 
just and reasonable, and agreeable to every thing we know of America, may be the more necessary.

We have been long ago told by F. Charlevoix, from whence it is, that many people have formed a contemptible opinion of this country that lies on and about the Missisippi. They are misled, says he, by the relations of some seafaring people, and others, who are no manner of judges of such things, and have never seen any part of the country but the coast side, about Mobile, and the mouths of the Mississippi; which our author here tells us is as dismal to appearance, the only thing those people are capable of judging of, as the interior parts of the country, which they never saw, are delightful, fruitful, and inviting. They tell us, besides, that the country is unhealthful; because there happens to be a marsh at the mouth of the Missisippi, (and what river is there without one?) which they imagine must be unhealthful, rather than that they know it to be so; not considering, that all the coast both of North and South America is the same; and not knowing, that the whole continent, above this single part on the coast, is the most likely, from its situation, and has been found by all the experience that has been had of it, to be the most healthy part of all North America in the same climates, as will abundantly appear from the following and all other accounts.

To give a general view of those countries, we should consider them as they are naturally divided into four parts; 1. The sea coast; 2. The Lower Louisiana, or western part of Carolina; 3. The Upper Louisiana, or western part of Virginia; and 4, the river Missisippi.

I. The sea coast is the same with all the rest of the coast of North America to the southward of New York, and indeed from thence to Mexico, as far as we are acquainted with it. It is all a low flat sandy beach, and the soil for some twenty or thirty miles distance from the shore, more or less, is all a pine barren, as it is called, or a sandy desart; with few or no good ports or harbours on the coast, especially in all those southern parts of America, from Chesapeak bay to Mexico. But however barren this coast is in other respects, it is entirely covered with tall pines, which afford great store of pitch, tar, and tur- 
pentine. These pines likewise make good masts for ships; which I have known to last for twenty odd years, when it is well known, that our common masts of New England white pine will often decay in three or four years. These masts were of that kind that is called the pitch pine, and lightwood pine; of which I knew a ship built that ran for sixteen years, when her planks of this pine were as sound and rather harder than at first, although her oak timbers were rotten. The cypress, of which there is such plenty in the swamps on this coast, is reckoned to be equally serviceable, if not more so, both for masts (of which it would afford the largest of any tree that we know), and for ship building. And ships might be built of both these timbers for half the price perhaps of any others, both on account of the vast plenty of them, and of their being so easily worked.

In most parts of these coasts likewise, especially about the Missisippi, there is great plenty of cedars and ever-green oaks; which make the best ships of any that are built in North America. And we suspect it is of these cedars and the American cypress, that the Spaniards build their ships of war at the Havanna. Of these there is the greatest plenty, immediately; to the westward of the mouth of the Missisippi where "large vessels can go to the lake of the Chetimachas, and nothing hinders them to go and cut the finest oaks in the world, with which all that coast is covered*;" which, moreover, is a sure sign of a very good, instead of a bad soil; and accordingly we see the French have settled their tobacco plantations thereabouts. It is not without reason then, that our author tells us, the largest navies might be built in that country at a very small expence.

From this it appears, that even the sea coast, barren as it is, from which the whole country has been so much depreciated, is not without its advantages, and those peculiarly adapted to a trading and maritime nation. Had these sandy desarts indeed been in such a climate as Canada, they would have been of as little value, as many would make them here. It might be difficult indeed to settle colonies merely for these or any other

* Charlevoix Hist. N. France, Tom. III. p. 444. 
productions of those poor lands: but to the westward of the Missisippi, the coast is much more fruitful all along the bay of Mexico; being watered with a great number of rivers, the banks of which are very fertile, and are covered with forests of the tallest oaks, \&c. as far as to New Mexico, a thing not to be seen any where else on these coasts. The coast alone will supply all the products of North America, and is as convenient to navigation as any part of it, without going nigh the Missisippi; so that it is with good reason our author says, "That country promises great riches to such as shall inhabit it, from the excellent quality of its lands*," in such a climate.

These are the productions of the dry (we cannot call them high) grounds: the swamps, with which this coast abounds, are still more fruitful, and abundantly compensate the avidity and barrenness of the soil around them. They bear rice in such plenty, especially the marsh about New Orleans, "That the inhabitants reap the greatest advantage from it, and reckon it the manna of the land $\dagger . "$ It was such marshes on the Nile, in the same climate, that were the granary of the Roman empire. And from a few such marshes in Carolina, not to be compared to those on the Missisippi, either in extent or fertility, Britain receives at least two or three hundred thousand pounds a year, and might vend twice that value of their products.

But however barren or noxious these low lands on the sea coast may be, they extend but a little way about the Missisippi, not above thirty or forty miles in a straight line, on the east side of that river, and about twice as far on the west side; in which last, the lands are, in recompence, much more fruitful. To follow the course of the river indeed, which runs very obliquely south-east and north-west, as well as crooked, they reckon it eighty-two leagues from the mouth of the river to the Cut-Point, where the high lands begin.

II. By the Lower Louisiana, our author means only the Delta of the Missisippi, or the drowned lands made by the overflowing of the river. But we may more properly give 
that appellation to the whole country, from the low and flat sea coast above described, to the mountains, which begin about the latitude $35^{\circ}$, a little above the river St. Francis; that is, five degrees of latitude, or three hundred and fifty statute miles from the coast; which they reckon to be six hundred and sixty miles up the Missisippi. About that latitude a continued ridge of mountains runs westward from the Apalachean mountains nigh to the banks of the Missisippi, which are thereabouts very high, at what we have called the Chicasaw Cliffs. Opposite to these on the west side of the Missisippi, the country is mountainous, and continues to be so here and there, as far as we have any accounts of it, westward to the mountains of New Mexico; which run in a chain of continued ridges from north to south, and are reckoned to divide that country from Louisiana, about 900 miles west from the Missisippi.

This is one entire level champaign country; the part of which that lies west of the Missisippi is 900 miles (of sixty to a degree) by 300 , and contains 270,000 square miles, as much as both France and Spain put together. This country lies in the latitude of those fruitful regions of Barbary, Syria, Persia, India, and the middle of China, and is alone sufficient to supply the world with all the products of North America. It is very fertile in every thing, both in lands and metals, by all the accounts we have of it; and is watered by several large navigable rivers, that spread over the whole country from the Missisippi to New Mexico; besides several smaller rivers on the coast west of the Missisippi, that fall into the bay of Mexico; of which we have no good accounts, if it be not that Mr. Coxe tells us of one, the river of the Cenis, which, he says, "is broad, deep, and navigable almost to its heads, which chiefly proceed from the ridge of hills that separate this province from New Mexico*," and runs through the rich and fertile country on the coast above mentioned.

The western part of this country is more fertile, says our author, than that on the east side of the Missisippi; in which part, however, says he, the lands are very fertile, with a rich

* Description of Carolina, p. 37. 
black mould three feet deep in the hills, and much deeper in the bottoms, with a strong clayey foundation. Reeds and canes even grow upon the hill sides; which, with the oaks, walnuts, tulip-trees, \&c. are a sure sign of a good and rich soil. And all along the Missisippi on both sides, Dumont tells, "The lands, which are all free from inundations, are excellent for culture, particularly those about Baton Rouge, Cut-Point, Arkansas, Natchez, and Yasous, which produce. Indian corn, tobacco, indigo, \&c. and all kinds of provisions and esculent plants, with little or no care or labour, and almost without culture; the soil being in all those places a black mould of an excellent quality*."

These accounts are confirmed by our own people, who were sent by the government of Virginia in 1742 , to view these the western parts of that province; and although they only went down the Ohio and Missisippi to New Orleans, they reported, that "they saw more good land on the Missisippi, and its many large branches, than they judge is in all the English colonies, as far as they are inhabited;" as appears from the report of that government to the board of trade.

What makes this fertile country more eligible and valuable, is, that it appears both from its situation, and from the experience the French have had of it $\dagger$, to be by far the most healthful of any in all these southern parts of North America: a thing of the last consequence in settling colonies, especially in those southern parts of America, which are in general very unhealthful. All the sea coasts of our colonies, to the southward of Chesapeak bay, or even of New-York, are low and flat, marshy and swampy, and very unhealthful on that account: and those on and about the bay of Mexico, and in Florida, are withal excessively hot and intemperate, so that white people are unfit for labour in them; by which all our southern colonies, which alone promise to be of any great advantage to the nation, are so thin of people, that we have but 25,000 white people in all South Carolina $\$$. But those lands on the Missisippi are, on

* Memoires, I. 16.

$\dagger$ See p. 120, 121.

\# Description of South Carolina. by— p. 30 . 
the contrary, high, dry, hilly, and in some places mountainous at no great distance from the river, besides the ridges of the Apalachean mountains above mentioned, that lie to the northward of them; which must greatly refresh and cool the air all over the country, especially in comparison of what it is on the low and flat, sandy and parched sea coasts of our present colonies. These high lands begin immediately above the Delta, or drowned lands, at the mouth of the Missisippi; above which the banks of that river are from one hundred to two hundred feet high, without any marshes about them; and continue such for nine hundred miles to the river Ohio, especially on the east side of the river*.

Such a situation on rich and fertile lands in that climate, and on a navigable river, must appear to be of the utmost consequence. It is only from the rich lands on the river sides (which indeed are the only lands that can generally be called rich in all countries, and especially in North America), that this nation reaps any thing of value from all the colonies it has in that part of the world. But "rich lands on river sides in hot climates are extremely unhealthful, says a very good judget, and we have often found to our cost. How ought we then to value such rich and healthful countries on the Missisippi? As much surely as some would depreciate and vilify them. It may be observed, that all the countries in America are only populous in the inland parts, and generally at a distance from navigation; as the sea coasts both of North and South America are generally low, damp, excessively hot, and unhealthful; at least in all the southern parts, from which alone we can expect any considerable returns. Instances of this may be seen in the adjacent provinces of Mexico, New Mexico, Terra Firma, Peru, Quito, \&c. and far more in our southern colonies, which never became populous, till the people removed to the inland parts, at a distance from the sea. This we are in a manner prevented to do in our colonies, by the mountains which surround us, and confine us to the coast; whereas on the Missisippi the whole continent is open to them, and they have, besides, this healthy 
situation on the lower parts of that river, at a small distance from the sea.

If those things are duly considered, it will appear, that they who are possessed of the Missisippi, will in time command that continent; and that we shall be confined on the sea coasts of our colonies, to that unhealthful situation, which many would persuade us is so much to be dreaded on the Missisippi. It is by this means that we have so very few people in all our southern colonies; and have not been able to get in one hundred years above twenty-five thousand people in South Carolina; when the French has not less than eighty or ninety thousand in Canada, besides ten or twelve thousand on the Missisippi, to oppose to them. The low and drowned lands, indeed, about the mouth of the Missisippi must no doubt be more or less unhealthful; but they are far from being so very pernicious as many represent them. The waters there are fresh, which we know, by manifold experience in America, are much less prejudicial to health than the offensive fetid marshes, that are to be found every where else on the salt waters. Accordingly we are credibly informed, that some of the inhabitants of New Orleans say, they never enjoyed better health even in France; and for that reason they invite their countrymen, in their letters to them, we are told, to come and partake of the salutary benefits of that delightful country. The clearing, draining, and cultivating of those low lands, must make a very great change upon them, from the accounts we have had of them in their rude and uncultivated state.

III. The Upper Louisiana we call that part of the continent, which lies to the northward of the mountains above mentioned in latitude $35^{\circ}$. This country is in many places hilly and mountainous for which reason we cannot expect it to be so fertile as the plains below it. But those hills on the west side of the Missisippi are generally suspected to contain mines, as well as the mountains of New Mexico, of which they are a continuation. But the fertile plains of Louisiana are perhaps more valuable than all the mines of Mexico; which there would be no doubt of, if they were duly cultivated. They will breed and maintain ten times as many people, and supply them with 
many more necessaries, and articles of trade and navigation, than the richest mines of Peru.

The most important place in this country, and perhaps in all North America, is at the Forks of the Missisippi, where the Ohio falls into that river; which, like another ocean, is the general receptacle of all the rivers that water the interior parts of that vast continent. Here those large and navigable rivers, the Ohio, river of the Cherokees, Wabache, Illinois, Missouri, and Missisippi, besides many others, which spread over that whole continent, from the Apalachean mountains to the mountains of New Mexico, upwards of one thousand miles, both north, south, east, and west, all meet together at this spot; and that in the best climate, and one of the most fruitful countries of any in all that part of the world, in the latitude $37^{\circ}$, the latitude of the Capes of Virginia, and of Santa Fé, the capital of New Mexico. By that means there is a convenient navigation to this place from our present settlements to New Mexico; and from all the inland parts of North America, farther than we are acquainted with it: and all the natives of that continent, those old friends and allies of the French, have by that means a free and ready access to this place; nigh to which the French formed a settlement, to secure their interest on the frontiers of all our southern colonies. In short this place is the centre of that vast continent, and of all the nations in it, and seems to be intended by nature to command them both; for which reason it ought no longer to be neglected by Britain. As soon as we pass the Apalachean mountains, this seems to be the most proper place to settle at; and was pitched upon for that purpose, by those who were the best acquainted with those countries, and the proper places of making settlements in them, of any we know. And if the settlements at this place had been made, as they were proposed, about twenty years ago, they might have prevented, or at least frustrated, the late attempts to wrest that country, and the territories of the Ohio, out of the hands of the English; and they may do the same again.

But many will tell us, that those inland parts of North America will be of no use to Britain, on account of their dis- 
tance from the sea, and inconvenience to navigation. That indeed might be said of the parts which lie immediately beyond the mountains, as the country of the Cherokees, and Ohio Indians about Pitsburg, the only countries thereabouts that we can extend our settlements to; which are so inconvenient to navigation, that nothing can be brought from them across the mountains, at least none of those gross commodities, which are the staple of North America; and they are as inconvenient to have any thing carried from them, nigh two thousand miles, down the river Ohio, and then by the Missisippi. For that reason those countries, which we look upon to be the most convenient, are the most inconvenient to us of any, although they join upon our present settlements. It is for these reasons, that the first settlements we make beyond the mountains, that is, beyond those we are now possessed of, should be upon the Missisippi, as we have said, convenient to the navigation of that river; and in time those new settlements may come to join to our present plantations; and we may by that means reap the benefit of all those inland parts of North America, by means of the navigation of the Missisippi, which will be secured by this post at the Forks. If that is not done, we cannot see how any of those inland parts of America, and the territories of the Ohio, which were the great objects of the present war, can ever be of any use to Britain, as the inhabitants of all those countries can otherwise have little or no correspondence with it.

IV. This famous river, the Missisippi, is navigable upwards of two thousand miles, to the falls of St. Anthony in latitude $45^{\circ}$, the only fall we know in it, which is 16 degrees of latitude above its mouth; and even above that fall, our author tells us, there is thirty fathom of water in the river, with a proportionate breadth. About one thousand miles from its mouth it receives the river Ohio, which is navigable one thousand miles farther, some say one thousand five hundred, nigh to its source, not far from Lake Ontario in New York; in all which space there is but one fall or rapide in the Ohio, and that navigable both up and down, at least in canoes. This fall is three hundred miles from the Missisippi, and one thousand three hundred from the sea, with five fathom of water up to 
it. The other large branches of the Ohio, the river of the Cherokees, and the Wabache, afford a like navigation, from lake Erie in the north to the Cherokees in the south, and from thence to the bay of Mexico, by the Missisippi : not to mention the great river Missouri, which runs to the north-west parts of New Mexico, much farther than we have any good accounts of that continent. From this it appears, that the Missouri affords the most extensive navigation of any river we know; so that it may justly be compared to an inland sea, which spreads over nine tenths of all the continent of North America; all which the French pretended to lay claim to, for no other reason but because they were possessed of a paltry settlement at the mouth of this river.

If those things are considered, the importance of the navigation of the Missisippi, and of a port at the mouth of it, will abundantly appear. Whatever that navigation is, good or bad, it is the only one for all the interior parts of North America, which are as large as a great part of Europe; no part of which can be of any service to Britain, without the navigation of the Missisippi, and settlements upon it. It is not without reason then, that we say, whoever are possessed of this river, and of the vast tracts of fertile lands upon it, must in time command that continent, and the trade of it, as well as all the natives in it, by the supplies which this navigation will enable them to furnish those people. By those means, if the French, or any others, are left in possession of the Missisippi, while we neglect it, they must command all that continent beyond the Apalachean mountains, and disturb our settlements much more than ever they did, or were able to do; the very thing they engaged in this war to accomplish, and we to prevent.

The Missisippi indeed is rapid for twelve hundred miles, as far as to the Missouri, which makes it difficult to go up the river by water. For that reason the French have been used to quit the Missisippi at the river St. Francis, from which they have a nigher way to the Forks of the Missisippi by land. But however difficult it may be to ascend the river, it is, notwithstanding often done; and its rapidity facilitates a descent upon it, and a ready conveyance for those gross commodities, which 
are the chief staple of North America, from the most remote places of the continent above mentioned: and as for lighter European goods, they are more easily carried by land, as our Indian traders do, over great part of the continent, on their horses, of which this country abounds with great plenty.

The worst part of the navigation, as well as of the country, is reckoned to be at the mouth of the river; which, however. our author tells us, is from seventeen to eighteen feet deep, and will admit ships of five hundred tons, the largest generally used in the plantation trade. And even this navigation might be easily mended, not only by clearing the river of a narrow bar in the passes, which our author, Charlevoix, and others, think might be easily done; but likewise by means of a bay described by Mr. Coxe, from the actual survey of his people, lying to the westward of the south pass of the river; which, he says, has from twenty-five to six fathom water in it, close to the shore, and not above a mile from the Missisippi, above all the shoals and difficult passes in it, and where the river has one hundred feet of water. By cutting through that one mile then, it would appear that a port might be made there for ships of any burden; the importance of which is evident, from its commanding all the inland parts of North America on one side, and the pass from Mexico on the other; so as to be preferable in these respects even to the Havanna; not to mention that it is fresh water, and free from worms, which destroy all the ships in those parts.

And as for the navigation from the Missisippi to Europe, our author shews that voyage may be performed in six weeks; which is as short a time as our ships generally take to go to and from our colonies. They go to the Missisippi with the trade winds, and return with the currents.

It would lead us beyond the bounds of a preface, to shew the many advantages of those lands on the Missisippi to Britain, or the necessity of possessing them. That would require a treatise by itself, of which we can only give a few abstracts in this place. For this purpose we should compare those lands with our present colonies; and should be well informed of the quantity and condition of the lands we already possess, before 
we can form any just judgement of what may be farther proper or requisite.

Our present possessions in North America between the sea and the mountains appear, from many surveys and actual mensurations, as well as from all the maps and other accounts we have of them, to be at a medium about three degrees of longitude, or one hundred and forty miles broad, in a straight line; and they extend from Georgia, in latitude $32^{\circ}$, to the bay of Fundi, in latitude $45^{\circ}$ (which is much farther both north and south than the lands appear to be of any great value); which makes 13 degrees difference of latitude, or 780 miles: this length multiplied by the breadth 140 , makes 109,200 square miles. This is not above as much land as is contained in Britain and Ireland; which, by Templeman's Survey, make 105,634 square miles. Instead of being as large as a great part of Europe then, as we are commonly told, all the lands we possess in North America, between the sea and mountains, do not amount to much more than these two islands. This appears farther, from the particular surveys of each of our colonies, as well as from this general estimate of the whole.

Of these lands which we thus possess, both the northern and southern parts are very poor and barren, and produce little or nothing, at least for Britain. It is only in our middle plantations, Virginia, Maryland, and Carolina, that the lands produce any staple commodity for Britain, or that appear to be fit for that purpose. In short, it is only the more rich and fertile lands on and about Chesapeak bay, with a few swamps in Carolina, like the lands on the Missisippi, that turn to any great account to this nation in all North America, or that are ever likely to do it. This makes the quantity of lands that produce any staple commodity for Britain in North America incredibly small, and vastly less than what is commonly imagined. It is reckoned, that there are more such lands in Virginia, than in all the rest of our colonies; and yet it appeared from the public records, about twenty-five years ago, that there was not above as much land patented in that colony, which is at the same time the oldest of any in all North America, than is in the county of Yorkshire, in England, to-wit, 
4684 square miles; although the country was then settled to the mountains.

If we examine all our other colonies, there will appear to be as great a scarcity and want of good lands in them, at least to answer the great end of colonies, the making of a staple commodity for Britain. In short, our colonies are already settled to the mountains, and have no lands, either to extend their settlements, as they increase and multiply; to keep up their plantations of staple commodities for Britain; or to enlarge the British dominions by the number of foreigners that remove to them; till they pass those mountains, and settle on the Missisippi.

This scarcity of land in our colonies proceeds from the mountains, with which they are surrounded, and by which they are confined to this narrow tract, and a low vale, along the sea side. The breadth of the continent from the Atlantic ocean to the Missisippi, appears to be about 600 miles (of 60 to a degree) of which there is about 140 at a medium, or 150 at most, that lies between the sea and mountains: and there is such another, and rather more fertile tract of level and improveable lands, about the same breadth, between the western parts of those mountains and the Missisippi: so that the mountainous country which lies between these two, is equal to them both, and makes one half of all the lands between the Missisippi and Atlantic ocean; if we except a small tract of a level champaign country upon the heads of the Ohio, which is possessed by the Six Nations, and their dependents. These mountainous and barren desarts, which lie immediately beyond our present settlements, are not only unfit for culture themselves, and so inconvenient to navigation, whether to the ocean, or to the Missisippi, that little or no use can be made of them; but they likewise preclude us from any access to those more fertile lands that lie beyond them, which would otherwise have been occupied long ago, but never can be settled, so at least as to turn to any account to Britain, without the possession and navigaion of the Missisippi; which is, as it were, the sea of all the inland parts of North America beyond the Apalachean mountains, without which those inland parts of that continent can never turn to any account to this nation. 
It is this our situation in North America, that renders all that continent beyond our present settlements of little or no use, at least to Britain; and makes the possession of the Missisippi absolutely necessary to reap the benefit of it. We possess but a fourth part of the continent between that river and the ocean; and but a tenth part of what lies east of Mexico; and can never enjoy any great advantages from any more of it, till we settle on the Missisippi.

How necessary such settlements on the Missisippi may be, will farther appear from what we possess on this side of it. The lands in North America are in general but very poor or barren; and if any of them are more fertile, the soil is light and shallow, and soon worn out with culture. It is only the virgin fertility of fresh lands, such as those on the Missisippi, that makes the lands in North America appear to be iruitful, or that renders them of any great value to this nation. But such lands in our colonies, that have hitherto produced their staple commodities for Britain, are now exhausted and worn out, and we meet with none such on this side of the Missisippi. But when their lands are worn out, neither the value of their commodities, nor the circumstances of the planters, will admit of manuring them, at least to any great advantage to this nation.

The staple commodities of North America are so gross and bulky, and of so small value, that it generally takes one half of them to pay the freight and other charges in sending them to Britain; so that unless our planters have some advantage in making them, such as cheap, rich, and fresh lands, they never can make any; their returns to Britain are then neglected, and the trade is gained by others who have these advantages; such as those who may be possessed of the Missisippi, or by the Germans, Russians, Turks, \&c. who have plenty of lands, and labour cheap: by which means they make more of our staple of North America, tobacco, than we do ourselves; while we cannot make their staple of hemp, flax, iron, pot-ash, \&c. By that means our people are obliged to interfere with their mother country, for want of the use of those lands of which there is such plenty in North America, to produce these commodities that are so much wanted from thence. 
The consequences of this may be much more prejudicial to this nation, than is commonly apprehended. This trade of North America, whatever may be the income from it, consists in those gross and bulky commodities that are the chief and principal sources of navigation; which maintain whole countries to make them, whole fleets to transport them, and numbers of people to manufacture them at home; on which accounts this trade is more profitable to a nation, than the mines of Mexico or Peru. If we compare this with other branches of trade, as the sugar trade, or even the fishery, it will appear to be by far the most profitable to the nation, whatever those others may be to a few individuals. We set a great value on the fishery; in which we do not employ a third part of the seamen that we do in the plantation trade of North America; and the same may be said of the sugar trade. The tobacco trade alone employs more seamen in Britain, than either the fishery, or sugar trade*; and brings in more money to the nation than all the products of America perhaps put together.

But those gross commodities that afford these sources of navigation, however valuable they may be to the public, and to this nation in particular, are far from being so to individuals: they are cheap, and of small value, either to make, or to trade

* By the best accounts we have, there were 4000 seamen employed in the tobacco trade, in the year 1733, when the inspection on tobacco passed into a law; and we may perhaps reckon them now 4500, although some reckon them less.

By the same accounts, taken by the custom-house officers, it appeared, that the number of British ships employed in all America, including the fishery, were 1400 , with 17,000 seamen; besides 9000 or 10,000 seamen belonging to North-America, who are all ready to enter into the service of Britain on any emergency or encouragement.

Of these there were but 4000 seamen employed in the fishery from Britain; and about as many, or 3600 , in the sugar trade.

The French, on the other hand, employ upwards of 20,000 seamen in the fishery, and many more than we do in the sugar trade.

In short, the plantation trade of North America is to Britain, what the fishery is to France, the great nursery of seamen, which may be much improved. It is for this reason that we have always thought this nation ought, for its safety, to enjoy an exclusive right to the one or the other of these at least. 
in them; and for that reason they are neglected by private people, who never think of making them, unless the public takes care to give them all due encouragement, and to set them about those employments; for which purpose good and proper lands, such as those on the Missisippi, are absolutely necessary, without which nothing can be done.

The many advantages of such lands that produce a staple for Britain, in North America, are not to be told. The whole interest of the nation in those colonies depends upon them, if not the colonies themselves. Such lands alone enable the colonies to take their manufactures and other necessaries from Britain, to the mutual advantage of both. And how necessary that may be will appear from the state of those colonies in North America, which do not make, one with another, as much as is sufficient to supply them only with the necessary article of cloathing; not to mention the many other things they want and take from Britain; and even how they pay for that is more than any man can tell. In short, it would appear that our colonies in North America cannot subsist much longer, if at all, in a state of dependence for all their manufactures and other necessaries, unless they are provided with other lands that may enable them to purchase them; and where they will find any such lands, but upon the Missisippi, is more than we can tell. When their lands are worn out, are poor and barren, or in an improper climate or situation, or that they will produce nothing to send to Britain, such lands can only be converted into corn and pasture grounds; and the people in our colonies are thereby necessarily obliged, for a bare subsistence, to interfere with Britain, not only in manufactures, but in the very produce of their lands.

By this we may perceive the absurdity of the popular outcry, that we have already land enough, and more than we can make use of in North America. They who may be of that opinion should shew us, where that land is to be found, and what it will produce, that may turn to any account to the nation. Those people derive their opinion from what they see in Europe, where the quantity of land that we possess in North America, will, no doubt, maintain a greater number of people than we have there. But they should consider, that those people in 
Europe are not maintained by the planting of a bare raw commodity, with such immense charges upon it, but by farming, manufactures, trade, and commerce; which they will soon reduce our colonies to, who would confine them to their present settlements, between the sea coast and the mountains that surround them.

Some of our colonies perhaps may imagine they cannot subsist without these employments; which indeed would appear to be the case in their present state: but that seems to be as contrary to their true interest, as it is to their condition of British colonies. They have neither skill, materials, nor any other conveniences to make manufactures; whereas their lands require only culture to produce a staple commodity, providing they are possessed of such as are fit for that purpose. Manufactures are the produce of labour, which is both scarce and dear among them; whereas lands are, or may, and should be made, both cheap and in plenty; by which they may always reap much greater profits from the one than the other. That is, moreover, a certain pledge for the allegiance and dependance of the colonies; and at the same time makes their dependance to become their interest. It has been found by frequent experience, that the making of a staple commodity for Britain, is more profitable than manufactures, providing they have good lands to work.

It were to be wished indeed, that we could support our interest in America, and those sources of navigation, by countries that were more convenient to it, than those on the Missisippi. But that, we fear, is not to be done, however it may be desired. We wish we could say as much of the lands in Florida, and on the bay of Mexico, as of those on the Missisippi : but they are not to be compared to these, by all accounts, however convenient they may be in other respects to navigation. In all those southern and maritime parts of that continent the lands are in general but very poor and mean, being little more than pine barrens, or sandy desarts. The climate is at the same time so intemperate, that white people are in a great measure unfit for labour in it, as much as they are in the islands; this obliges them to make use of slaves, which are now become so dear, that it is to be doubted, whether all the produce 
of those lands will enable the proprietors of them to purchase slaves, or any other labourers; without which they can turn to little or no account to the nation, and those countries can support but very few people, if it were only to protect and defend them.

The most convenient part of those countries seems to be about Mobile and Pensacola; which are, as it were, an entrepot between our present settlements and the Missisippi, and safe station for our ships. But it is a pity that the lands about them are the most barren, and the climate the most intemperate, by all accounts, of any perhaps in all America*. And our author tells us, the lands are not much better even on the river of Mobile; which is but a very inconsiderable one. But the great inconvenience of those countries proceeds from the number of Indians in them; which will make it very difficult to settle any profitable plantations among them, especially in the inland parts that are more fertile; whereas the Missisippi is free from Indians for 1000 miles. It was but in the year 1715, that those Indians overran all the colony of Carolina, even to Charles-Town; by which the French got possession of that country, and of the Missisippi ; both which they had just before, in June 1713, dispossessed us of.

If we turn our eyes again to the lands in our northern colonies, it is to be feared we can expect much less from them. There is an inconvenience attending them, with regard to any improvements on them for Britain, which is not to be remedied. The climate is so severe, and the winters so long, that the people are obliged to spend that time in providing the necessaries of life, which should be employed in profitable colonies, on the making of some staple commodity, and returns to Britain. They are obliged to feed their creatures for five or six months in the year, which employs their time in summer, and takes up the best of their lands, such as they are, which should produce their staple commodities, to provide for themselves and their stocks against winter. For that reason the people in all our northern colonies are necessarily obliged to become farm-

* See page 49, 111, \&c. Charlevoix Hist. N. France, Tom. III. 484. Laval, infra, \&c. 
ers, to make corn and provisions, instead of planters, who make a staple commodity for Britain; and thereby interfere with their mother country in the most material and essential of all employments to a nation, agriculture.

In short, neither the soil nor climate will admit of any improvements for Britain, in any of those northern colonies. If they would produce any thing of that kind, it must be hemp; which never could be made in them to any advantage, as appears from many trials of it in New England*. The great dependance of those northern colonies is upon the supplies of lumber and provisions which they send to the islands. But as they increase and multiply, their woods are cut down, lumber becomes scarce and dear, and the number of people inhances the value of land, and of every thing it produces, especially provisions.

If this is the case of those northern colonies on the sea coast, what can we expect from the inland parts; in which the soil is not only more barren, and the climate more severe, but they are, with all these disadvantages, so inconvenient to navigation, both on account of their distance, and of the many falls and currents in the river St. Lawrence, that it is to be feared those inland parts of our northern colonies will never produce any thing for Britain, more than a few furrs; which they will do much better in the hands of the natives, than in ours.

These our northern colonies, however, are very populous, and increase and multiply very fast. There are above a million of people in them, who can make but very little upon their lands for themselves, and still less for their mother country. For these reasons it is presumed, it would be an advantage to them, as well as to the whole nation, to remove their spare people, who want lands, to those vacant lands in the southern parts of the continent, which turn to so much greater account than any that they are possessed of. There they may have the necessaries of life in the greatest plenty; their stocks maintain themselves the whole year round, with little or no cost or labour; "by which means many people have a thousand head

* See Douglas's Hist. N. America. Elliot's Improvements on New England, \&c. 
of cattle, and for one man to have two hundred, is very common, with other stock in proportion*." This enables them to bestow their whole labour, both in summer and winter, on the making of some staple commodity for Britain, getting lumber and provisions for the islands, \&c. which both enriches them and the whole nation. That is much better, surely, than to perish in winter for want of cloathing, which they must do unless they make it; and to excite those grudges and jealousies. which must ever subsist between them and their mother country in their present state, and grow so much the worse, the longer they continue in it.

The many advantages that would ensue from the peopling of those southern parts of the continent from our northern colonies, are hardly to be told. We might thereby people and secure those countries, and reap the profits of them, without any loss of people; which are not to be spared for that purpose in Britain, or any other of her dominions. This is the great use and advantage that may be made of the expulsion of the French from those northern parts of America. They have hitherto obliged us to strengthen those northern colonies, and have confined the people in them to towns and townships, in which their labour could turn to no great account, either to themselves or to the nation, by which we have, in a great measure, loss the labour of one half of the people in our colonies. But as they are now free from any danger on their borders, they may extend their settlements with safety, disperse themselves on plantations, and cultivate those lands that may turn to some account, both to them and to the whole nation. In short, they may now make some staple commodity for Britain; on which the interest of the colonies, and of the nation in them, chiefly depends; and which we can never expect from those colonies in their present situation.

What those commodities are, that we might get from those southern parts of North America, will appear from the following accounts; which we have not room here to consider more particularly. We need only mention hemp, flax, and silk, those great articles and necessary materials of manufactures; for which alone this nation pays at least a million and an half

* Description of South Carolina, p. 68. 
a-year, if not two millions, and could never get them from all the colonies we have. Cotton and indigo are equally useful. Not to mention copper, iron, potash, \&c. which, with hemp, flax, and silk, make the great balance of trade against the nation, and drain it of its treasure; when we might have those commodities from our colonies for manufactures, and both supply ourselves and others with them. Wine, oil, raisins, and currants, \&c. those products of France and Spain, on which Britain expends so much of her treasure, to enrich her enemies, might likewise be had from those her own dominions. Britain might thereby cut off those resources of her enemies; secure her colonies for the future; and prevent such calamities of war, by cultivating those more laudable arts of peace: which will be the more necessary, as these are the only advantages the nation can expect, for the many millions that have been expended on America.

\section{A Description of the Harbour of Pensacola.}

$A^{S}$ the harbour of Pensacola will appear to be a considerable acquisition to Britain, it may be some satisfaction to give the following account of it, from F. Laval, royal professor of mathematics, and master of the marine academy at Toulon; who was sent to Louisiana, on purpose to make observations, in 1719 ; and had the accounts of the officers who took Pensacola at that time, and surveyed the place.

"The colonies of Pensacola, and of Dauphin-Island, are at present on the decline, the inhabitants having removed to settle at Mobile and Biloxi, or at New-Orleans, where the lands are much better; for at the first the soil is chiefly sand, mixed with little earth. The land, however, is covered with woods of pines, firs, and oaks; which make good trees, as well as at Ship-Island. The road of Pensacola is the only good port thereabouts for large ships, and Ship-Island for small ones, where vessels that draw from thirteen to fourteen feet water, may ride in safety, under the island, in fifteen feet, and a good holding ground; as well as in the other ports, which are all only open roads, exposed to the south, and from west to east.

"Pensacola is in north-latitude $30^{\circ} 25^{\prime}$; and is the only road in the bay of Mexico, in which ships can be safe from all 
winds. It is land-locked on every side, and will hold a great number of ships, which have very good anchorage in it, in a good holding ground of soft sand, and from twenty-five to thirty-four feet of water. You will find not less than twentyone feet of water on the barr, which is at the entrance into the road, providing you keep in the deepest part of the channel. Before a ship enters the harbour, she should bring the fort of Pensacola to bear between north and north $1 / 4$ east, and keep that course till she is west or west $1 / 4$ south, from the fort on the island of St. Rose, that is, till that fort bears east, and east 1/4 north. Then she must bear away a little to the land on the west side, keeping about mid-way between that and the island, to avoid a bank on this last, which runs out to some distance west-north-west from the point of the island.

"If there are any breakers on the ledge of rocks, which lie to the westward of the barr, as often happens; if there is any wind, that may serve for a mark to ships, which steer along that ledge, at the distance of a good musket-shot, as they enter upon the barr; then keep the course above mentioned. Sometimes the currents set very strong out of the road, which you should take care of, less they should carry you upon these rocks.

"As there is but half a foot rising (levèe) on the barr of Pensacola, every ship of war, if it be not in a storm, may depend upon nineteen (perhaps twenty) feet of water, to go into the harbour, as there are twenty-one feet on the barr. Ships that draw twenty feet must be towed in. By this we see, that ships of sixty guns may go into this harbour: and even seventy gun ships, the largest requisite in that country in time of war, if they were built flat-bottomed, like the Dutch ships, might pass every where in that harbour.

"In 1719 Pensacola was taken by Mr. Champmelin, in the Hercules man of war, of sixty-four guns, but carried only fiftysix; in company with the Mars, pierced for sixty guns, but had in only fifty-four; and the Triton, pierced for fifty-four guns, but carried only fifty; with two frigates of thirty-six and twenty guns*.

* The admiral was on board of the Hercules, which drew twenty-one feet of water, and there were but twenty-two feet into the harbour in the 
"This road is subject to one inconvenience; several rivers fall into it, which occasion strong currents, and make boats or canoes, as they pass backwards and forwards, apt to run a-ground; but as the bottom is all sand, they are not apt to founder. On the other hand there is a great advantage in this road; it is free from worms, which never breed in fresh water, so that vessels are never worm-eaten in it."

But F. Charlevoix seems to contradict this last circumstance: "The bay of Pensacola would be a pretty good port, (says he) if the worms did not eat the vessels in it, and if there was a little more water in the entrance into it; for the Hercules, commanded by Mr. Champmelin, touched upon it." It is not so certain then, that this harbour is altogether free from worms; although it may not be so subject to them, as other places in those climes, from the many small fresh water rivers that fall into this bay, which may have been the occasion of these accounts, that are seemingly contradictory.

In such a place ships might at least be preserved from worms, in all likelihood, by paying their bottoms with aloes, or mixing it with their other stuff. That has been found to prevent the biting of these worms; and might be had in plenty on the spot. Many kinds of aloes would grow on the barren sandy lands about Pensacola, and in Florida, which is the proper soil for them; and would be a good improvement for those lands, which will hardly bear any thing else to advantage, whatever use is made of it.

Having room in this place, we may fill it up with an answer to a common objection against Louisiana; which is,

highest tides; so that they despaired of carrying in this ship. But an old Canadian, named Crimeau, a man of experience, who was perfectly acquainted with that coast, boasted of being able to do it, and succeeded; for which he was the next year honoured with letters of noblesse. Dumont (an officer there at that time) $\mathbf{1 1 . 2 2 .}$

But Bellin, from the charts of the admiralty, makes but twenty feet of water on the barr of Pensacola. The difference may arise from the tides, which are very irregular and uncertain on all that coast, according to the winds; never rising above three feet, sometimes much less. In twenty-four hours the tide ebbs in the harbour for eighteen or nineteen hours, and flows five or six. Laval. 
that this country is never likely to turn to any account, because the French have made so little of it.

But that objection, however common, will appear to proceed only from the ignorance of those who make it. No country can produce any thing without labourers; which, it is certain, the French have never had in Louisiana, in any numbers at least, sufficient to make it turn to any greater account than it has hitherto done. The reason of this appears not to be owing to the country, but to their proceedings and misconduct in it. Out of the many thousand people who were contracted for by the grantees, to be sent to Louisiana in 1719 , there were but eight hundred sent, we see; and of these the greatest part were ruined by their idle schemes, which made them and others abandon the country entirely. The few again who remained in it were cut off by an Indian massacre in 1729 , which broke up the only promising settlements they had in the country, those of the Natchez, and Yasous, which were never afterwards reinstated. Instead of encouraging the colony in such misfortunes, the minister, Cardinal Fleuri, either from a spirit of œconomy, or because it might be contrary to some other of his views, withdrew his protection from it, gave up the public plantations, and must thereby, no doubt, have very much discouraged others. By these means they have had few or no people in Louisiana, but such as were condemned to be sent to it for their crimes, women of ill fame, deserted soldiers, insolvent debtors, and galley-slaves, forçats, as they call them; "who, looking on the country only as a place of exile, were disheartened at every thing in it; and had no regard for the progress of a colony, of which they were only members by compulsion, and neither knew nor considered its advantages to the state. It is from such people that many have their accounts of this country; and throw the blame of all miscarriages in it upon the country, when they are only owing to the incapacity and negligence of those who were instructed to settle it*."

* Charlevoix Hist. New France, Tom. III. p. 447. 


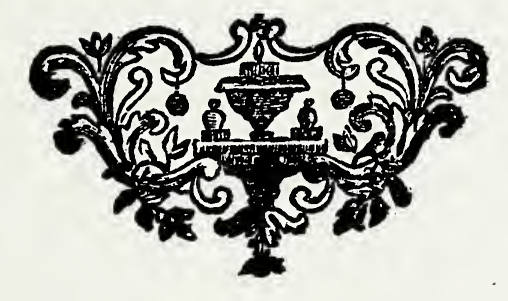







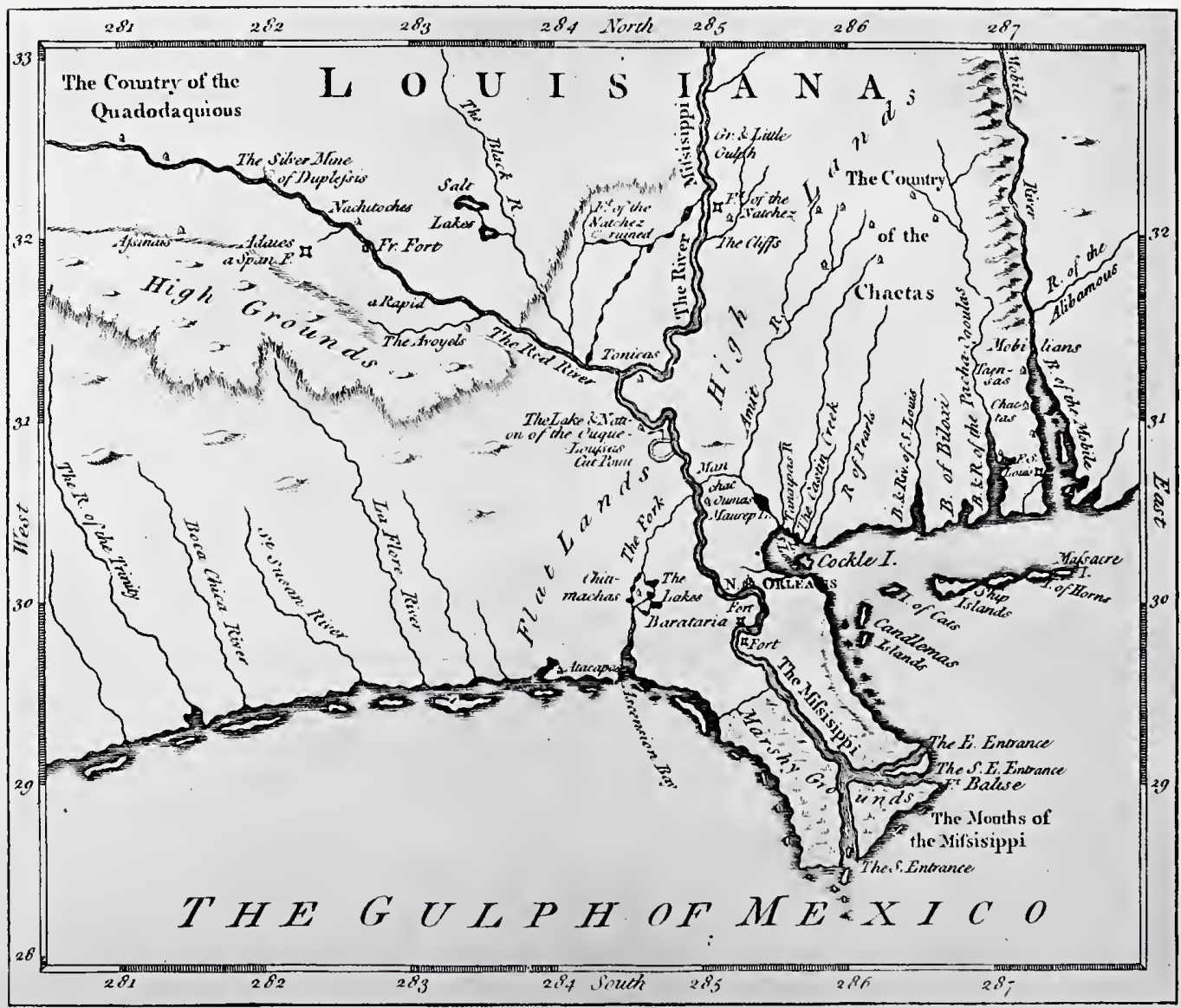



$\mathrm{T} \mathrm{H} \mathrm{E}$

\section{HISTORY \\ $\mathrm{OF}$ \\ L 0 U I S I A N A}

B O O K I.

The Transactions of the French in Louisiana.

\section{CHAPTER I.}

Of the first Discovery and Settlement of Louisiana.

A FTER the Spaniards came to have settlements on the Great

Antilles, it was not long before they attempted to make discoveries on the coasts of the Gulf of Mexico. In 1520, Lucas Vasquez de Aillon landed on the continent to the north of that Gulf, being favourably received by the people of that country, who made him presents in gold, pearls, and plated silver. This favourable reception made him return thither four years after; but the natives having changed their friendly sentiments towards him, killed two hundred of his men, and obliged him to retire.

In 1528, Pamphilo Nesunez* landed also on that coast, receiving from the first nations he met in his way, presents made in gold; which, by signs, they made him to understand, came from the Apalachean mountains, in the country which at this day goes under the name of Florida: and thither he attempted to go, undertaking a hazardous journey of twentyfive days. In this march he was so often attacked by the new people he continually discovered, and lost so many of his men, as only to think of re-embarking with the few that were left,

* Narvaez. 
happy to have himself escaped the dangers which his imprudence had exposed him to.

The relation published by the Historian of Dominico* Soto, who in 1539 landed in the Bay of St. Esprit, is so romantic, and so constantly contradicted by all who have travelled that country, that far from giving credit to it, we ought rather to suppose his enterprize had no success; as no traces of it have remained, any more than of those that went before. The inutility of these attempts proved no manner of discouragement to the Spaniards. After the discovery of Florida, it was with a jealous eye they saw the French settle there in 1564, under René de Laudonniere, sent thither by the Admiral de Coligni, where he built Fort Carolin; the ruins of which are still to be seen above the Fort of Pensacolat. There the Spaniards some time after attacked them, and forcing them to capitulate, cruelly murdered them, without any regard had to the treaty concluded between them. As France was at that time involved in the calamities of a religious war, this act of barbarity had remained unresented, had not a single man of Mont Marfan, named Dominique de Gourges, attempted, in the name of the nation, to take vengeance thereof. In 1567 , having fitted out a vessel, and sailed for Florida, he took three forts built by the Spaniards; and after killing many of them in the several attacks he made, hanged the rest: and having settled there a new post + returned to France. But the disorders of the state having prevented the maintaining that post, the Spaniards soon after retook possession of the country, where they remain to this day.

From that time the French seemed to have dropped all thoughts of that coast, or of attempting any discoveries therein; when the wars in Canada with the natives afforded them the

* Ferdinando.

$\dagger$ This intended settlement of Admiral Coligni was on the east coast of Florida, about St. Augustin, instead of Pensacola. De Laet is of opinion, that their Fort Carolin was the same with St. Augustin.

* He abandoned the country without making any settlement; nor have the French ever had any settlement in it from that day to this. See Laudonniere. Hakluyt, \&c. 
knowledge of the vast country they are possessed of at this day. In one of these wars a Recollet, or Franciscan Friar, name F. Hennepin, was taken and carried to the Illinois. As he had some skill in surgery, he proved serviceable to that people, and was also kindly treated by them: and being at full liberty, he travelled over the country, following for a considerable time the banks of the river St. Louis, or Missisipi, without being able to proceed to its mouth. However, he failed not to take possession of that country, in the name of Louis XIV., calling it Louisiana. Providence having facilitated his return to Canada, he gave the most advantageous account of all he had seen; and after his return to France, drew up a relation thereof, dedicated to M. Colbert.

The account he gave of Louisiana failed not to produce its good effects. Me de la Salle, equally famous for his misfortunes and his courage, undertook to traverse these unknown countries quite to the sea. In Jan. 1679 he set out from Quebec with a large detachment, and being come among the Illinois, there built the first fort France ever had in that country, calling it Crevecœur; and there he left a good garrison under the command of the Chevalier de Tonti. From thence he went down the river St. Louis, quite to its mouth; which, as has been said, is in the Gulf of Mexico: and having made observations, and taken the elevation in the best manner he could, returned by the same way to Quebec, from whence he passed over to France.

After giving the particulars of his journey to M. Colbert, that great minister, who knew of what importance it was to the state to make sure of so fine and extensive a country, scrupled not to allow him a ship and a small frigate, in order to find out, by the way of the gulf of Mexico, the mouth of the river St. Louis. He set sail in 1685: but his observations, doubtless, not having had all the justness requisite, after arriving in the gulf, he got beyond the river, and running too far westward, entered the bay of St. Bernard: and some misunderstanding happening between him and the officers of the vessels, he debarqued with the men under his command, and having settled a post in that place, undertook to go by land in quest of 
the great river. But after a march of several days, some of his people, irritated on account of the fatigue he exposed them to, availing themselves of an opportunity, when separated from the rest of his men, basely assassinated him. The soldiers, though deprived of their commander, still continued their route, and, after crossing many rivers, arrived at length at the Arkansas, where they unexpectedly found a French post lately settled. The Chevalier de Tonti was gone down from the fort of the Illinois, quite to the mouth of the river, about the time he judged M. de la Salle might have arrived by sea; and not finding him, was gone up again, in order to return to his post. And in his way entering the river of the Arkansas, quite to the village of that nation, with whom he made an alliance, some of his people insisted, they might be allowed to settle there; which was agreed to, he leaving ten of them in that place: and this small cantonment maintained its ground, not only because from time to time encreased by some Canadians, who came down this river; but above all, because those who formed it had the prudent precaution to live in peace with the natives, and treat as legitimate the children they had by the daughters of the Arkansas, with whom they matched out of necessity.

The report of the pleasantness of Louisiana spreading through Canada, many Frenchmen of that country repaired to settle there, dispersing themselves at pleasure along the river St. Louis, especially towards its mouth, and even in some islands on the coast, and on the river Mobile, which lies nearer Canada. The facility of the commerce with St. Domingo was, undoubtedly, what invited them to the neighbourhood of the sea, though the interior parts of the country be in all respects far preferable. However, these scattered settlements, incapable to maintain their ground of themselves, and too distant to be able to afford mutual assistance, neither warranted the possession of this country, nor could they be called a taking of possession. Louisiana remained in this neglected state, till M. d'Hiberville, Chef d' Escadre, having discovered, in 1698, the mouths of the river St. Louis, and being nominated Governor General of that vast country, carried thither the first colony in 1699. As he was a native of Canada, the colony almost entirely consisted of Canadians, among whom M. de Luchereau, 
uncle of Madam d'Hiberville, particularly distinguished himself.

The settlement was made on the river Mobile, with all the facility that could be wished; but its progress proved slow: for these first inhabitants had no other advantage above the natives, as to the necessaries of life, but what their own industry, joined to some rude tools, to give the plainest forms to timbers; afforded them.

The war which Louis IV, had at that time to maintain, and the pressing necessities of the state, continually engrossed the attention of the ministry, nor allowed them time to think of Louisiana. What was then thought most advisable, was to make a grant of it to some rich person; who, finding it his interest to improve that country, would, at the same time that he promoted his own interest, promote that of the state. Louisiana was thus ceded to M. Crozat. And it is to be presumed, had M. d'Hiberville lived longer, the colony would have made considerable progress: but that illustrious sea-officer, whose authority was considerable, dying at the Havannah, in 1701 (after which this settlement was deserted) a long time must intervene before a new Governor could arrive from France. The person pitched upon to fill that post, was M. de la Motte Cadillac, who arrived in that country in June 1713.

The colony had but a scanty measure of commodities, and money scarcer yet: it was rather in a state of languor, than of vigorous activity, in one of the finest countries in the world; because impossible for it to do the laborious works, and make the first advances, always requisite in the best lands.

The Spaniards, for a long time, considered Louisiana as a property justly theirs, because it constitutes the greatest part of Florida, which they first discovered. The pains the French were at then to settle there, roused their jealousy, to form the design of cramping us, by settling at the Assinaïs, a nation not very distant from the Nactchitoches, whither some Frenchmen had penetrated. There the Spaniards met with no small difficulty to form that settlement, and being at a loss how to accomplish it, one F. Ydalgo, a Franciscan Friar, took it in his head to write to the French, to beg their assistance in 
settling a mission among the Assinaïs. He sent three different copies of his letter hap-hazard three different ways to our settlements, hoping one of them at least might fall into the hands of the French.

Nor was he disappointed in his hope, one of them, from one post to another, and from hand to hand, falling into the hands of M. de la Motte. That General, incessantly taken up with the concerns of the colony, and the means of relieving it, was not apprized of the designs of the Spaniards in that letter; could only see therein a sure and short method to remedy the present evils, by favouring the Spaniards, and making a treaty of commerce with them, which might procure to the colony what it was in want of, and what the Spaniards abounded with, namely, horses, cattle, and money: He therefore communicated that letter to M. de St. Denis, to whom he proposed to undertake a journey by land to Mexico.

M. de St. Denis, for the fourteen years he was in Louisiana, had made several excursions up and down the country; and having a general knowledge of all the languages of the different nations which inhabit it, gained the love and esteem of these people, so far as to be acknowledged their Grand Chief. This gentleman, in other respects a man of courage, prudence, and resolution, was then the fittest person M. de la Motte could have pitched upon, to put his design in execution.

How fatiguing soever the enterprize was, M. de St. Denis undertook it with pleasure, and set out with twenty-five men. This small company would have made some figure, had it continued entire; but some of them dropped M. de St. Denis by the way, and many of them remained among the Nactchitoches, to whose country he was come. He was therefore obliged to set out from that place, accompanied only by ten men, with whom he traversed upwards of an hundred and fifty leagues in a country entirely depopulated, having on his route met with no nation, till he came to the Presidio, or fortress of St. John Baptist, on the Rio (river) del Norte, in New Mexico.

The Governor of this fort was Don Diego Raimond, an officer advanced in years. who favourbly received M. de St. 
Denis, on acquainting him, that the motive to his journey was F. Ydalgo's letter, and that he had orders to repair to Mexico. But as the Spaniards do not readily allow strangers to travel through the countries of their dominion in America, for fear the view of these fine countries should inspire notions, the consequences of which might be greatly prejudicial to them, D. Diego did not chuse to permit M. de St. Denis to continue his route, without the previous consent of the Viceroy. It was therefore necessary to dispatch a courier to Mexico, and to wait his return.

The courier, impatiently longed for, arrived at length, with the permission granted by the Duke of Linarez, Viceroy of Mexico. Upon which M. de St. Denis set out directly, and arrived at Mexico, June 5, 1715. The Viceroy had naturally an affection to France; M. de St. Denis was therefore favourably received, saving some precautions, which the Duke thought proper to take, not to give any disgust to some officers of justice who were about him.

The affair was soon dispatched; the Duke of Linarez having promised to make a treaty of commerce, as soon as the Spaniards should be settled at the Assinaïs; which M. de St. Denis undertook to do, upon his return to Louisiana.

\section{Chapter II.}

The Return of $M$. de St. Denis: His settling the Spaniards at the Assinaïs. His Second Journey to Mexico, and Return from thence.

M.

De St. Denis soon returned to the fort of St. John Baptist: after which he resolved to form the caravan, which was to be settled at the Assinaïs; at whose head M. de St. Denis put himself, and happily conducted it to the place appointed. And then having, in quality of Grand Chief, assembled the nation of the Assinaiis, he exhorted them to receive and use the Spaniards well. The veneration which that people had for him, made them submit to his will in all things; and thus the promise he had made to the Duke of Linarez was faithfully fulfilled. 
The Assinaïs are fifty leagues distant from the Nactchitoches. The Spaniards, finding themselves still at too great a distance from us, availed themselves of that first settlement, in order to form a second among the Adaies, a nation which is ten leagues from our post of the Nactchitoches: whereby they confine us on the west within the neighbourhood of the river St. Louis; and from that time it was not their fault, that they had not cramped us to the north, as I shall mention in its place.

To this anecdote of their history I shall, in a word or two, add that of their settlement at Pensacola, on the coast of Florida, three months after M. d'Hiberville had carried the first inhabitants to Louisiana, that country having continued to be inhabited by Europeans, ever since the garrison left there by Dominique de Gourges; which either perished, or deserted, for want of being supported*.

To return to M. de la Motte and M. de St. Denis : the former, ever attentive to the project of having a treaty of commerce concluded with the Spaniards, and pleased with the success of M. de St. Denis's journey to Mexico, proposed his return thither again, not doubting but the Duke of Linarez would be as good as his word, as the French had already been. M. de St. Denis, ever ready to obey, accepted the commission of his General. But this second journey was not to be undertaken as the first; it was proper to carry some goods, in order to execute that treaty, as soon as it should be concluded, and to indemnify himself for the expences he was to be at. Though the storehouses of M. Crozat were full, it was no easy matter to get the goods. The factors refused to give any on credit; nay, refused M. de la Motte's security; and there was no money to be had to pay them. The Governor was therefore obliged to form a company of the most responsible men of the colony: and to this company only the factors determined to advance the goods. This expedient was far from being agreeable to M. de St. Denis, who opened his mind to M. de la Motte on that head, and told him, that some or all of his partners would accompany the goods they had engaged to be security for; and that, although it was absolutely necessary the effects should appear to be his

* They returned to France. See p. 3. 
property alone, they would not fail to discover they themselves were the proprietors; which would be sufficient to cause their confiscation, the commerce between the two nations not being open. M. de la Motte saw the solidity of these reasons; but the impossibility of acting otherwise constrained him to supersede them: and, as M. de St. Denis had foreseen, it accordingly happened.

He set out from Mobile, August 13, 1716, escorted, as he all along apprehended, by some of those concerned; and being come to the Assinaïs, he there passed the winter. On the 19th of March, the year following, setting out on his journey, he soon arrived at the Presidio of St. John Baptist. M. de St. Denis declared these goods to be his own property, in order to obviate their confiscation, which was otherwise unavoidable; and wanted to shew some acts of bounty and generosity, in order to gain the friendship of the Spaniards. But the untractableness, the avarice, and indiscretion of the parties concerned, broke through all his measures; and to prevent the entire disconcerting of them, he hastened his departure for Mexico, where he arrived May 14, 1717. The Duke of Linarez was yet there, but sick, and on his death-bed. M. de St. Denis had, however, time to see him, who knew him again: and that Nobleman took care to have him recommended to the Viceroy his successor; namely, the Marquis of Balero, a man as much against the French as the Duke was for them.

M. de St. Denis did not long solicit the Marquis of Balero for concluding the treaty of commerce; he soon had other business to mind. F. Olivarez, who, on the representation of F. Ydalgo, as a person of a jealous, turbulent, and dangerous disposition, had been excluded from the mission to the Assinaïs, being then at the court of the Viceroy, saw with an evil eye the person who had settled F. Ydalgo in that mission, and resolved to be avenged on him for the vexation caused by that disappointment. He joined himself to an officer, named Don Martin de Alaron, a person peculiarly protected by the Marquis of Balero: and they succeeded so well with that nobleman, that in the time M. de St. Denis least expected, he found himself arrested, and clapt in a dungeon; from which he was not discharged 
till December 20 of this year, by an order of the Sovereign Council of Mexico, to which he found means to present several petitions. The Viceroy, constrained to enlarge him, allotted the town for his place of confinement.

The business of the treaty of commerce being now at an end, M. de St. Denis's attention was only engaged how to make the most of the goods, of which Don Diego Raymond had sent as large a quantity as he could, to the town of Mexico; where they were seized by D. Martin de Alaron, as contraband; he being one of the emissaries of his protector, appointed to persecute such strangers as did not dearly purchase the permission to sell their goods. M. de St. Denis could make only enough of his pillaged and damaged effects just to defray certain expences of suit, which, in a country that abounds with nothing else but gold and silver, are enormous.

Our prisoner having nothing further to engross his attention in Mexico, but the safety of his person, seriously bethought himself how to secure it; as he had ever just grounds to apprehend some bad treatment at the hands of his three avowed enemies. Having therefore planned the means of his flight, on September 25, 1718, as the night came on, he quitted Mexico, and placing himself in ambush at a certain distance from the town, waited till his good fortune should afford the means of travelling otherwise than on foot. About nine at night, a horseman, well-mounted, cast up. To rush of a sudden upon him, dismount him, mount his horse, turn the bridle, and set up a gallop, was the work of a moment only for St. Denis. He rode on at a good pace till day, then quitted the common road, to repose him: a precaution he observed all along, till he came near to the Presidio of St. John Baptist. From thence he continued his journey on foot; and at length, on April 2, 1719, arrived at the French colony, where he found considerable alterations.

From the departure of M. de St. Denis from Mexico, to his return again, almost three years had elapsed. In that long time, the grant of Louisiana was transferred from M. Crozat to the West India Company; M. de la Motte Cadillac was dead, and M. de Biainville, brother to M. d'Hiberville, succeeded as 
governor general. The capital place of the colony was no longer at Mobile, nor even at Old Biloxi, whither it had been removed: New Orleans, now begun to be built, was become the capital of the country, whither he repaired to give M. de Biainville an account of his journey; after which he retired to his settlement. The king afterwards conferred upon him the cross of St. Louis, in acknowledgement and recompence of his services.

The West India Company, building great hopes of commerce on Louisiana, made efforts to people that country, sufficient to accomplish their end. Thither, for the first time, they sent, in 1718, a colony of eight hundred: men some of which settled at New Orleans, others formed the settlements of the Natchez. It was with this embarkation I passed over to Louisiana.

\section{ChAPter III.}

Embarkation of eight hundred Men by the West India Company to Louisiana. Arrival and Stay at Cape François. Arrival at Isle Dauphine. Description of that Island.

THE embarkation was made at Rochelle on three different vessels, on one of which I embarked. For the first days of our voyage we had the wind contrary, but no high sea. On the eighth the wind turned more favourable. I observed nothing interesting till we came to the Tropick of Cancer, where the ceremony of baptizing was performed on those who had never been a voyage: after passing the Tropick, the Commodore steered too much to the south, our captain observed. In effect, after several days sailing, we were obliged to bear off to the north: we afterwards discovered the isle of St. Juan de Porto Rico, which belongs to the Spaniards. Losing sight of that, we discovered the island of St. Domingo; and a little after, as we bore on, we saw the Grange, which is a rock, overtopping the steep coast, which is almost perpendicular to the edge of the water. This rock, seen at a distance, seems to have the figure of a grange, or barn. A few hours after we 
arrived at Cape François, distant from that rock only twelve leagues.

We were two months in this passage to Cape François; both on account of the contrary winds, we had on setting out, and of the calms, which are frequent in those seas: our vessel, besides, being clumsy and heavy, had some difficulty to keep up with the others; which, not to leave us behind, carried only their four greater sails, while we had out between seventeen and eighteen.

It is in those seas we meet with the Tradewinds; which though weak, a great deal of way might be made, did they blow constantly, because their course is from east to west without varying: storms are never observed in these seas, but the calms often prove a great hindrance; and then it is necessary to wait some days, till a grain, or squall, brings back the wind: a grain is a small spot seen in the air, which spreads very fast, and forms a cloud, that gives a wind, which is brisk at first, but not lasting, though enough to make way with. Nothing besides remarkable is here seen, but the chace of the flyingfish by the Bonitas.

The Bonita is a fish, which is sometimes two feet long; extremely fond of the flying-fish; which is the reason it always keeps to the places where these fish are found: its flesh is extremely delicate and of a good flavour.

The flying-fish is of the length of a herring, but rounder. From its sides, instead of fins, issue out two wings, each about four inches in length, by two in breadth at the extremity; they fold together and open out like a fan, and are round at the end; consisting of a very fine membrane, pierced with a vast many little holes, which keep the water, when the fish is out of it: in order to avoid the pursuit of the Bonita, it darts into the air, spreads out its wings, goes straight on, without being able to turn to the right or left; which is the reason, that as soon as the toilets, or little sheets of water, which fill up the small holes of its wings, are dried up, it falls down again; and the same Bonita, which pursued it in the water, still following it with his eye in the air, catches it when fallen into the water; it sometimes falls on board ships. The Bonita, in his turn, 
becomes the prey of the seamen, by means of little puppets, in the form of flying-fish, which it swallows, and by that means is taken.

We stayed fifteen days at Cape François, to take in wood and water, and to refresh. It is situate on the north part of the island of St. Domingo, which part the French are in possession of, as the Spaniards are of the other. The fruits and sweet-meats of the country are excellent, but the meat good for nothing, hard, dry, and tough. This country being scorched, grass is very scarce, and animals therein languish and droop. Six weeks before our arrival, fifteen hundred persons died of an epidemic distemper, called the Siam distemper.

We sailed from Cape François, with the same wind, and the finest weather imaginable. We then passed between the islands of Tortuga and St. Domingo, where we espied Port de Paix, which is over-against Tortuga: we afterwards found ourselves between the extremities of St. Domingo and Cuba which belongs to the Spaniards: we then steered along the south coast of this last, leaving to the left Jamaica, and the great and little Kayemans, which are subject to the English. We at length quitted Cuba at Cape Anthony, steering for Louisiana a north west course. We espied land in coming towards it, but so flat, though distant but a league from us, that we had great difficulty to distinguish it, though we had then but four fathom water. We put out the boat to examine the land, which we found to be Candlemas island (la Chandeleur.) We directly set sail for the island of Massacre, since called Isle Dauphine, situated three leagues to the south of that continent, which forms the Gulf of Mexico to the north, at about $27^{\circ} 35^{\prime}$ North latitude, and $288^{\circ}$ of longitude. A little after we discovered the Isle Dauphine, and cast anchor before the harbour, in the road, because the harbour itself was choaked up. To make this passage we took three months, and arrived only August 25th. We had a prosperous voyage all along, and the more so, as no one died, or was even dangerously ill the whole time, for which we caused Te Deum solemnly to be sung.

We were then put on shore with all our effects. The company had undertaken to transport us with our servants and 
effects, at their expence, and to lodge, maintain and convey us to our several concessions, or grants.

This gulf abounds with delicious fish; as the sarde (pilchard) red fish, cod, sturgeon, ringed thornback, and many other sorts, the best in their kind. The sarde is a large fish; its flesh is delicate, and of a fine flavour, the scales grey, and of a moderate size. The red fish is so called, from its red scales, of the size of a crown piece. The cod, fished for on this coast, is of the middling sort, and very delicate. The thornback is the same as in France. Before we quit this island, it will not, perhaps, be improper to mention some things about it.

The Isle Massacre was so called by the first Frenchman who landed there, because on the shore of this island they found a small rising ground, or eminence, which appeared the more extraordinary in an island altogether flat, and seemingly formed only by the sand, thrown in by some high gusts of wind. As the whole coast of the gulf is very flat, and along the continent lies a chain of such islands, which seem to be mutually joined by their points, and to form a line parallel with the continent, this small eminence appeared to them extraordinary: it was more narrowly examined, and in different parts thereof they found dead mens bones, just appearing above the little earth that covered them. Then their curiosity led them to rake off the earth in several places; but finding nothing underneath, but a heap of bones, they cried out with horror, Ah! what a Massacre! They afterwards understood by the natives, who are at no great distance off, that a nation adjoining to that island, being at war with another much more powerful, was constrained to quit the continent, which is only three leagues off, and to remove to this island, there to live in peace the rest of their days; but that their enemies, justly confiding in their superiority, pursued them to this their feeble retreat, and entirely destroyed them; and after raising this inhuman trophy of their victorious barbarity, retired again. I myself saw this fatal monument, which made me imagine this unhappy nation must have been even numerous toward its period, as only the bones of their warriors, and aged men must have lain there, their custom being to make slaves of their 
young people. Such is the origin of the first name of this island, which, on our arrival, was changed to that of Isle Dauphine: an act of prudence, it should-seem, to discontinue an appellation, so odious, of a place that was the cradle of the colony; as Mobile was its birth-place.

This island is very flat, and all a white sand, as are all ihe others, and the coast in like manner. Its length is about seven leagues from east to west; its breadth a short league from south to north, especially to the east, where the settlement was made, on account of the harbour which was at the south end of the island, and choaked up by a high sea, a little before our arrival: this east end runs to a point. It is tolerably well stored with pine; but so dry and parched, on account of its crystal sand, as that no greens or pulse can grow therein, and beasts are pinched and hard put to it for sustenance.

In the mean time, M. de Biainville, commandant general for the company in this colony, was gone to mark out the spot on which the capital was to be built, namely, one of the banks of the river Missisippi, where at present stands the city of New Orleans, so called in honour of the duke of Orleans, then regent.

ChAPTER IV.

The Author's Departure for his Grant. Description of the Places he passed through, as far as New Orleans.

THE time of my departure, so much wished for, came at length. I set out with my hired servants, all my effects, and a letter for M. Paillou, major general at New Orleans, who commanded there in the absence of M. de Biainville. We coasted along the continent, and came to lie in the mouth of the river of the Pasca-Ogoulas; so called, because near its mouth, and to the east of a bay of the same name, dwells a nation, called Pasca-Ogoulas, which denotes the Nation of Bread. Here it may be remarked, that in the province of Louisiana, the appellation of several people terminates in the word Ogoula, which signifies nation; and that most of the rivers derive their names from the nations which dwell on 
their banks. We then passed in view of Biloxi, where formerly was a petty nation of that name; then in view of the bay of St. Louis, leaving to the left successively Isle Dauphine, Isle a Corne, (Horne-island,) Isle aux Vaisseaux, (Ship-island,) and Isle aux Chats, (Cat-island).

I have already described Isle Dauphine, let us now proceed to the three following. Horn-island is very flat and tolerably wooded, about six leagues in length, narrowed to a point to the west side. I know not whether it was for this reason, or on account of the number of horned cattle upon it, that it received this name; but it is certain, that the first Canadians, who settled on Isle Dauphine, had put most of their cattle, in great numbers, there; whereby they came to grow rich even when they slept. These cattle not requiring any attendance, or other care, in this island, came to multiply in such a manner, that the owners made great profits of them on our arrival in the colony.

Proceeding still westward, we meet Ship-island; so called, because there is a small harbour, in which vessels at different times have put in for shelter. But as the island is distant four leagues from the coast, and that this coast is so flat, that boats cannot approach nearer than half a league, this harbour comes to be entirely useless. This island may be about five leagues in length, and a large league in breadth at the west point. Near that point to the north is the harbour, facing the continent; towards the east end it may be half a league in breadth: it is sufficiently wooded, and inhabited only by rats, which swarm there.

At two leagues distance, going still westward, we meet Cat-island; so called, because at the time it was discovered, great numbers of cats were found upon it. This island is very small, not above half a league in diameter. The forests are over-run with underwood: a circumstance which, doubtless, determined M. de Biainville to put in some hogs to breed; which multiplied to such numbers, that, in 1722, going to hunt them, no other creatures were to be seen; and it was judged, that in time they must have devoured each other. It was found they had destroyed the cats. 
All these islands are very flat, and have the same bottom of white sand; the woods, especially of the three first, consist of pine; they are almost all at the same distance from the continent, the coast of which is equally sandy.

After passing the bay of St. Louis, of which I have spoken, we enter the two channels which lead to Lake Pontchartrain, called at present the Lake St. Louis: of these channels, one is named the Great, the other the Little; and they are about two leagues in length, and formed by a chain of islets, or little isles, between the continent and Cockle-island. The great channel is to the south.

We lay at the end of the channels in Cockle-island; so called, because almost entirely formed of the shells named Coquilles des Palourdes, in the sea-ports, without a mixture of any others. This isle lies before the mouth of the Lake St. Louis to the east, and leaves at its two extremities two outlets to the lake; the one, by which we entered, which is the channel just mentioned; the other, by the Lake Borgne. The lake, moreover, at the other end westward, communicates, by a channel, with the Lake Maurepas; and may be about ten leagues in length from east to west, and seven in breadth. Several rivers, in their course southward, fall into it. To the south of the lake is a great creek (Bayouc, a stream of dead water, with little or no observable current) called Bayouc St. Jean; it comes close to New Orleans, and falls into this lake at Grass Point (Pointe aux Herbes) which projects a great way into the lake, at two leagues distance from Cockle-island. We passed near that point, which is nothing but a quagmire. From thence we proceeded to the Bayouc Choupic, so denominated from a fish of that name, and three leagues from the Pointe aux Herbes. The many rivulets, which discharge themselves into this lake, make its waters almost fresh, though it communicates with the sea: and on this account it abounds not only with sea fish but with fresh water fish, some of which, particularly carp, would appear to be of a monstrous size in France.

We entered this Creek Choupic: at the entrance of which is a fort at present. We went up this creek for the space of a league, and landed at a place where formerly stood the village 
of the natives, who are called Cola-Pissas, an appellation corrupted by the French, the true name of that nation being Aquelou-Pissas, that is, the nation of men that hear and see. From this place to New Orleans, and the river Missisippi, on which that capital is built, the distance is only a league.

\section{ChAPTER V.}

The Author put in Possession of his Territory. His Resolution to go and settle among the Natchez.

BEING arrived at the Creek Choupic the Sicur Lavigne, a Canadian, lodged me in a cabin of the Aquelou-Pissas, whose village he had bought. He gave others to my workmen for their lodging; and we were all happy to find, upon our arrival, that we were under shelter, in a place that was uninhabited. A few days after my arrival I bought an Indian female slave of one of the inhabitants, in order to have a person who could dress our victuals, as I perceived the inhabitants did all they could to entice away our labourers, and to gain them by fair promises. As for my slave and me, we did not understand one another's language; but I made myself to be understood by signs, which these natives comprehend very easily: she was of the nation of the Chitimachas, with whom the French had been at war for some years.

I went to view a spot on St. John's Creek, about half a league distant from the place where the capital was to be founded, which was yet only marked out by a hut, covered with palmetto-leaves, and which the commandant had caused to be built for his own lodging; and after him for M. Paillou, whom he left commandant of that post. I had chosen that place preferably to any others, with a view to dispose more easily of my goods and provisions, and that I might not have them to transport to a great distance. I told M. Paillou of my choice, who came and put me in possession, in the name of the West-India company.

I built a hut upon my settlement, about forty yards from the creek of St. John, till I could build my house, and lodging 
for my people. As my hut was composed of very combustible materials, I caused a fire to be made at a distance, about half way from the creek, to avoid accidents: which occasioned an adventure, that put me in mind of the prejudices they have in Europe, from the relations that are commonly current. The account I am going to give of it, may have upon those who think as I did then, the same effect that it had upon me.

It was almost night, when my slave perceived, within two yards of the fire, a young alligator, five feet long, which beheld the fire without moving. I was in the garden hard by, when she made me repeated signs to come to her; I ran with speed, and upon my arrival she shewed me the crocodile, without speaking to me; the little time that I examined it, I could see, its eyes were so fixed on the fire, that all our motions could not take them off. I ran to my cabin to look for my gun, as I am a pretty good marksman: but what was my surprize, when I came out, and saw the girl with a great stick in her hand attacking the monster! Seeing me arrive, she began to smile, and said many things, which I did not comprehend. But she made me understand, by signs, that there was no occasion for a gun to kill such a beast; for the stick she shewed me was sufficient for the purpose.

The next day the former master of my slave came to ask me for some salad-plants; for I was the only one who had any garden-stuff, having taken care to preserve the seeds I had brought over with me. As he understood the language of the natives, I begged him to ask the girl, why she had killed the alligator so rashly. He began to laugh, and told me, that all new comers were afraid of those creatures, although they have no reason to be so: and that I ought not to be surprized at what the girl had done, because her nation inhabited the borders of a lake, which was full of those creatures; that the children, when they saw the young ones come on land, pursued them, and killed them, by the assistance of the people of the cabin, who made good cheer of them.

I was pleased with my habitation, and I had good reasons, which I have already related, to make me prefer it to others; notwithstanding I had room to believe, that the situation was 
none of the healthiest, the country about it being very damp. But this cause of an unwholesome air does not exist at present, since they have cleared the ground, and made a bank before the town. The quality of that land is very good, for what I had sown came up very well. Having found in the spring some peach-stones which began to sprout, I planted them; and the following autumn they had made shoots, four feet high, with branches in proportion.

Notwithstanding these advantages, I took a resolution to quit this settlement, in order to make another one, about a hundred leagues higher up; and I shall give the reasons, which, in my opinion, will appear sufficient to have made me take that step.

My surgeon came to take his leave of me, letting me know, he could be of no service to me, near such a town as was forming; where there was a much abler surgeon than himself; and that they had talked to him so favourably of the post of the Natchez, that he was very desirous to go there, and the more so, as that place, being unprovided with a surgeon, might be more to his advantage. To satisfy me of the truth of what he told me, he went immediately and brought one of the old inhabitants, of whom I had bought my slave, who confirmed the account he had given me of the fineness of the country of the Natchez. The account of the old man, joined to many other advantages, to be found there, had made him think of abandoning the place where we were, to settle there; and he reckoned to be abundantly repaid for it in a little time.

My slave heard the discourse that I have related, and as she began to understand French, and I the language of the country, she addressed herself to me thus: "Thou art going, then, to that country; the sky is much finer there; game is in much greater plenty; and as I have relations, who retired there in the war which we had with the French, they will bring us every thing we want: they tell me that country is very fine, that they live well in it, and to a good old age."

Two days afterwards I told M. Hubert what I had heard of the country of the Natchez. He made answer, that he was 


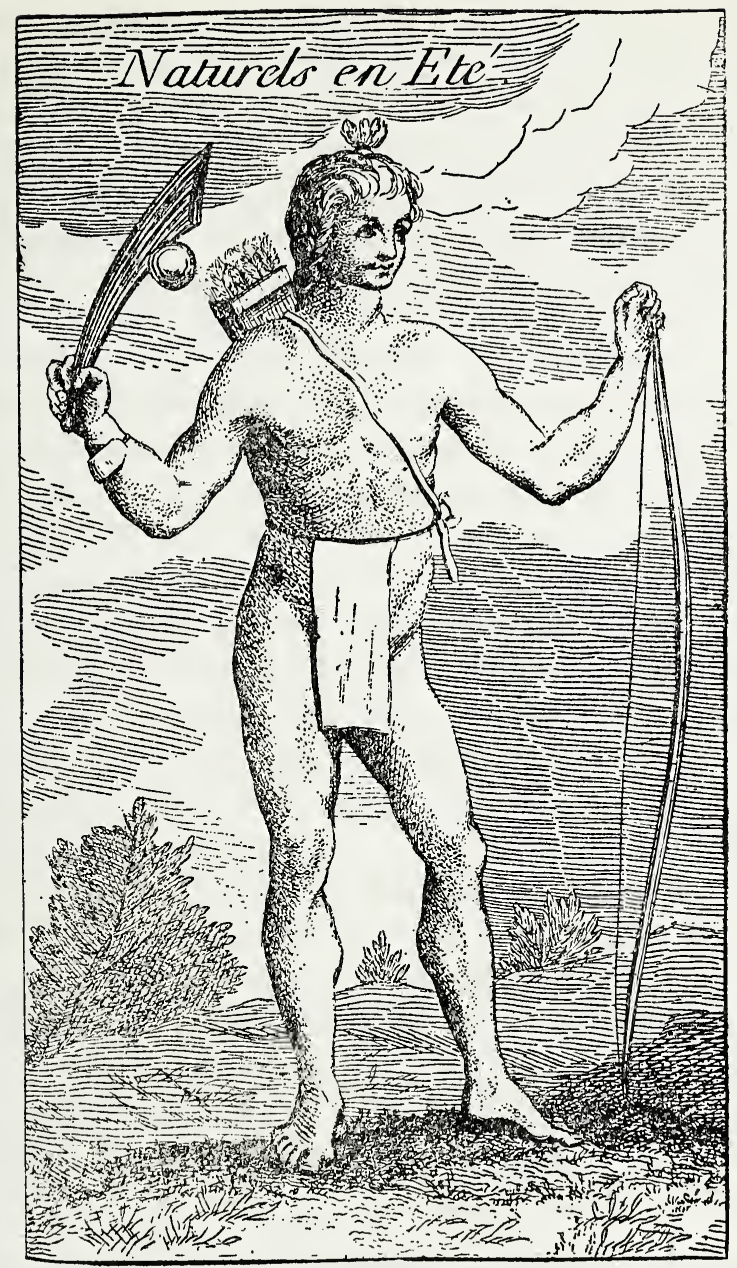

Indian in summer time

so persuaded of the goodness of that part of the country, that he was making ready to go there himself, to take up his grant, and to establish a large settlement for the company: and, continued he, "I shall be very glad, if you do the same: we shall be company to one another, and you will unquestionably do your business better there than here."

This determined me to follow his advice: I quitted my settlement, and took lodgings in the town, till I should find an 
opportunity to depart, and receive some negroes whom I expected in a short time. * My stay at New Orleans appeared long, before I heard of the arrival of the negroes. Some days after the news of their arrival, M. Hubert brought me two good ones, which had fallen to me by lot. One was a young negro about twenty, with his wife of the same age; which cost me both together 1320 livres, or 55£. sterling.

Two days after that I set off with them alone in a pettyaugre (a large canoe,) because I was told we should make much better speed in such a vessel, than in the boats that went with us; and that I had only to take powder and ball with me, to provide my whole company with game sufficient to maintain us; for which purpose it was necessary to make use of a paddle, instead of oars, which make too much noise for the game. I had a barrel of powder, with fifteen pounds of shot, which I thought would be sufficient for the voyage: but I found by experience, that this was not sufficient for the vast plenty of game that is to be met with upon that river, without ever going out of your way. I had not gone above twenty-eight leagues, to the grant of M. Paris du Vernai, when I was obliged to borrow of him fifteen pounds of shot more. Upon this I took care of my ammunition, and shot nothing but what was fit for our provision; such as wild ducks, summer ducks, teal, and saw-bills. Among the rest I killed a carancro, wild geese, cranes, and flamingo's; I likewise often killed young alligators; the tail of which was a feast for the slaves, as well as for the French and Canadian rowers.

Among other things I cannot omit to give an account of a monstrous large alligator I killed with a musquet ball, as it lay upon the bank, about ten feet above the edge of the water. We measured it, and found it to be nineteen feet long, its head three feet and a half long, above two feet nine inches broad, and the other parts in proportion: at the belly it was two feet two inches thick; and it infected the whole air with the odor of musk. M. Mehane told me, he had killed one twenty-two feet long.

* Chap. VIII. 
After several days navigation, we arrived at Tonicas on Christmas eve; where we heard mass from M. d' Avion, of the foreign missions, with whom we passed the rest of the holydays, on account of the good reception and kind invitation he gave us. I asked him, if his great zeal for the salvation of the natives was attended with any success; he answered me, that notwithstanding the profound respect the people shewed him, it was with the greatest difficulty he could get leave to baptize a few children at the point of death; that those of an advanced age excused themselves from embracing our holy religion because they are too old, say they, to accustom themselves to rules, that are so difficult to be observed; that the chief, who had killed the physician, that attended his only son in a distemper of which he died, had taken a resolution to fast every Friday while he lived, in remorse for his inhumanity with which he had been so sharply reproached by him. This grand chief attended both morning and evening prayers; the women and children likewise assisted regularly at them; but the men, who did not come very often, took more pleasure in ringing the bell. In other respects, they did not suffer this zealous pastor to want for any thing, but furnished him with whatever he desired.

We were yet twenty-five leagues to the end of our journey to the Natchez, and we left the Tonicas, where we saw nothing interesting, if it were not several steep hills, which stand together; among which there is one that they name the White Hill, because they find in it several veins of an earth, that is white, greasy, and very fine, with which I have seen very good potters ware made. On the same hill there are veins of ochre, of which the Natchez had just taken some to stain their earthen ware, which looked well enough; when it was besmeared with ochre, it became red on burning.

At last we arrived at the Natchez, after a voyage of twenty-four leagues; and we put on shore at a landing-place, which is at the foot of a hill two hundred feet high, upon the top of which Fort Rosalie* is built, surrounded only with pallisadoes.

* Fort Rosalie, in the country of the Natchez, was at first pitched upon for the metropolis of this colony. But though it be necessary to 
About the middle of the hill stands the magazine, nigh to some houses of the inhabitants, who are settled there, because the ascent is not so steep in that place; and it is for the same reason that the magazine is built there. When you are upon the top of this hill, you discover the whole country, which is an extensive beautiful plain, with several little hills interspersed here and there, upon which the inhabitants have built and made their settlements. The prospect of it is charming.

On our arrival at the Natchez I was very well received by M. Loire de Flaucourt, storekeeper of this post, who regaled us with the game that abounds in this place; and after two days I hired a house near the fort, for M. Hubert and his family, on their arrival, till he could build upon his own plantation. He likewise desired me to choose two convenient parcels of land, whereon to settle two considerable plantations, one for the company, and the other for himself. I went to them in two or three days after my arrival, with an old inhabitant for my guide, and to shew me the proper places, and at the same time to choose a spot of ground for myself; this last I pitched upon the first day, because it is more easy to choose for one's self than for others.

I found upon the main road that leads from the chief village of the Natchez to the fort, about an hundred paces from this last, a cabin of the natives upon the road side, surrounded with a spot of cleared ground, the whole of which I bought by means of an interpreter. I made this purchase with the more pleasure, as I had upon the spot, wherewithal to lodge me and my people, with all my effects: the cleared ground was about six acres, which would form a garden and a plantation for

begin by a settlement near the sea; yet if ever Louisiana comes to be in a flourishing condition, as it may very well be, it appears to me, that the capital of it cannot be better situated than in this place. It is not subject to inundations of the river; the air is pure; the country very extensive; the land fit for every thing, and well watered; it is not at too great a distance from the sea, and nothing hinders vessels to go up to it. In fine, it is within reach of every place intended to be settled. Charlevoix, Hist. de la N. France, III. 415.

This is on the east side of the Missisippi, and appears to be the first post on that river which we ought to secure. 
tobacco, which was then the only commodity cultivated by the inhabitants. I had water convenient for my house, and all my land was very good. On one side stood a rising ground with a gentle declivity, covered with a thick field of canes, which always grow upon the rich lands; behind that was a great meadow, and on the other side was a forest of white walnuts (Hiccories) of nigh fifty acres, covered with grass knee deep. All this piece of ground was in general good, and contained about four hundred acres of a measure greater than that of Paris: the soil is black and light.

The other two pieces of land, which M. Hubert had ordered me to look for, I took up on the border of the little river of the Natchez, each of them half a league from the great village of that nation, and a league from the fort; and my plantation stood between these two and the fort, bounding the two others. After this I took up my lodging upon my own plantation, in the hut I had bought of the Indian, and put my people in another, which they built for themselves at the side of mine; so that I was lodged pretty much like our wood-cutters in France, when they are at work in the woods.

As soon as I was put in possession of my habitation, I went with an interpreter to see the other fields, which the Indians had cleared upon my land, and bought them all, except one, which an Indian would never sell to me: it was situated very convenient for me, I had a mind for it, and would have given him a good price; but I could never make him agree to my proposals. He gave me to understand, that without selling it, he would give it up to me, as soon as I should clear my ground to his; and that while he stayed on his own ground near me, I should always find him ready to serve me, and that he would go a-hunting and fishing for me. This answer satisfied me, because I must have had twenty negroes, before I could have been able to have reached him; they assured me likewise, that he was an honest man; and far from having any occasion to complain of him as a neighbour, his stay there was extremely serviceable to me.

I had not been settled at the Natchez six months, when I found a pain in my thigh, which, however, did not hinder me 
to go about my business. I consulted our surgeon about it, who caused me to be bleeded; on which the humour fell upon the other thigh, and fixed there with such violence, that I could not walk without extreme pain. I consulted the physicians and surgeons of New Orleans, who advised me to use aromatic baths; and if they proved of no service, I must go to France, to drink the waters, and to bathe in them. This answer satisfied me so much the less, as I was neither certain of my cure by that means, nor would my present situation allow me to go to France. This cruel distemper, I believe, proceeded from the rains, with which $I$ was wet, during our whole voyage; and might be some effects of the fatigues I had undergone in war, during several campaigns I had made in Germany.

As I could not go out of my hut, several neighbours were so good as to come and see me, and every day we were no less than twelve at table from the time of our arrival, which was on the fifth of January, 1720. Among the rest F. de Ville, who waited there, in his journey to the Illinois, till the ice, which began to come down from the north, was gone. His conversation afforded me great satisfaction in my confinement, and allayed the vexation I was under from my two negroes being run away. In the mean time my distemper did not abate, which made me resolve to apply to one of the Indian conjurers, who are both surgeons, divines, and sorcerers; and who told. me he would cure me by sucking the place where I felt my pain. He made several scarifications upon the part with a sharp flint, each of them about as large as the prick of a lancet, and in such a form, that he could suck them all at once, which gave me extreme pain for the space of half an hour. The next day I found myself a little better, and walked about into my field, where they advised me to put myself in the hands of some of the Natchez, who, they said, did surprising cures, of which they told me many instances, confirmed by creditable people. In such a situation a man will do any thing for a cure, especially as the remedy, which they told me of, was very simple: it was only a poultice, which they put upon the part affected, and in eight days time I was able to walk to the fort, finding myself perfectly cured, as I have felt no return of my pain since that 
time. This was, without doubt, a great satisfaction to a young man, who found himself otherwise in good health, but had been confined to the house for four months and a half, without being able to go out a moment; and gave me as much joy as I could well have, after the loss of a good negro, who died of a defluxion on the breast, which he catched by running away into the woods, where his youth and want of experience made him believe he might live without the toils of slavery; but being found by the Tonicas, constant friends of the French, who live about twenty leagues from the Natchez, they carried him to their village, where he and his wife were given to a Frenchman, for whom they worked, and by that means got their livelihood; till M. de Montplaisir sent them home to me.

This M. de Montplaisir, one of the most agreeable gentlemen in the colony, was sent by the company from Clerac in Gascony, to manage their plantation at the Natchez, to make tobacco upon it, and to shew the people the way of cultivating and curing it; the company having learned, that this place produced excellent tobacco, and that the people of Clerac were perfectly well acquainted with the culture and way of managing it.

\section{CHAPTER VI.}

The Voyage of the Author to Biloxi. Description of that Place. Settlement of Grants. The Author discovers two Coppermines. His Return to the Natchez.

THE second year after my settling among the Natchez, I went to New Orleans, as I was desirous to sell my goods and commodities myself, instead of selling them to the travelling pedlars, who often require too great a profit for their pains. Another reason that made me undertake this voyage, was to send my letters to France myself, which I was certainly informed, were generally intercepted.

Before my departure, I went to the commandant of the fort, and asked him whether he had any letters for the government. I was not on very good terms of friendship with this commandant of the Natchez, who endeavoured to pay his court 
to the governor, at the expence of others. I knew he had letters for M. de Biainville, although he told me he had none, which made me get a certificate from the commissary general of this refusal to my demand; and at the same time the commissary begged me to carry down a servant of the company, and gave me an order to pay for his maintenance. As I made no great haste, but stopt to see my friends, in my going down the river, the commandant had time to send his letters, and to write to the governor, that I refused to take them. As soon as I arrived at Biloxi, this occasioned M. de Biainville to tell me, with some coldness, that I refused to charge myself with his letters. Upon this I shewed him the certificate of the commissary general; to which he could give no other answer, than by telling me, that at least I could not deny, that I had brought away by stealth a servant of the company. Upon this I shewed him the other certificate of the commissary general, by which he desired the directors to reimburse me the charges of bringing down this servant, who was of no use to him above; which put the governor in a very bad humour.

Upon my arrival at New Orleans I was informed, that there were several grantees arrived at New Biloxi. I thought fit then to go thither, both to sell my goods, and to get sure conveyance for my letters to France. Here I was invited to sup with M. d'Artaguette, king's lieutenant, who usually invited all the grantees, as well as myself. I there found several of the grantees, who were all my friends; and among us we made out a sure conveyance for our letters to France, of which we afterwards made use.

Biloxi is situate opposite to Ship-Island, and four leagues from it. But I never could guess the reason, why the principal settlement was made at this place, nor why the capital should be built at it; as nothing could be more repugnant to good sense; vessels not being able to come within four leagues of it; but what was worse, nothing could be brought from them, but by changing the boats three different times, from a smaller size to another still smaller; after which they had to go upwards of an hundred paces with small carts through the water to unload the least boats. But what ought still to have 
been a greater discouragement against making a settlement at Biloxi, was, that the land is the most barren of any to be found thereabouts; being nothing but a fine sand, as white and shining as snow, on which no kind of greens can be raised; besides, the being extremely incommoded with rats, which swarm there in the sand, and at that time ate even the very stocks of the guns, the famine being there so very great, that more than five hundred people died of hunger; bread being very dear, and flesh-meat still more rare. There was nothing in plenty but fish, with which this place abounds.

This scarcity proceeded from the arrival of several grantees all at once; so as to have neither provisions, nor boats to transport them to the places of their destination, as the company had obliged themselves to do. The great plenty of oysters, found upon the coast, saved the lives of some of them, although obliged to wade almost up to their thighs for them, a gun-shot from the shore. If this food nourished several of them, it threw numbers into sickness; which was still more heightened by the long time they were obliged to be in the water.

The grants were those of M. Law, who was to have fifteen hundred men, consisting of Germans, Provençals, \&c. to form the settlement. His land being marked out at the Arkansas, consisted of four leagues square, and was erected into a duchy, with accoutrements for a company of dragoons, and merchandize for more than a million of livres. M. Levans, who was a trustee of it, had his chaise to visit the different posts of the grant. But M. Law soon after becoming bankrupt, the company seized on all the effects and merchandise; and but a few of those who engaged in the service of that grant, remained at the Arkansas; they were afterwards all dispersed and set at liberty. The Germans almost to a man settled eight leagues above, and to the west of the capital. This grant ruined near a thousand persons at L'Orient before their embarkation, and above two hundred at Biloxi; not to mention those who came out at the same time with me in 1718. All this distress, of which I was a witness at Biloxi, determined me to make an excursion a few leagues on the coast, in order to pass some days 
with a friend, who received me with pleasure. We mounted horse to visit the interior part of the country a few leagues from the sea. I found the fields pleasant enough, but less fertile than along the Missisippi; as they have some resemblance of the neighbouring coast, which has scarce any other plants but pines, that run a great way, and some red and white cedars.

When we came to the plain, I carefully searched every spot that I thought worth my attention. In consequence of the search I found two mines of copper, whose metal plainly appeared above ground. They stood about half a league asunder. We may justly conclude that they are very rich, as they thus disclose themselves on the surface of the earth.

When I had made a sufficient excursion, and judged I could find nothing further to satisfy my curiosity, I returned to Biloxi, where I found two boats of the company, just preparing to depart for New Orleans, and a large pettyaugre, which belonged to F. Charlevoix the jesuit, whose name is well known in the republic of letters: with him I returned to New Orleans.

Some time after my return from New Orleans to the Natchez, towards the month of March 1722, a phænomenon happened, which frightened the whole province. Every morning, for eight days running, a hollow noise, somewhat loud, was heard to reach from the sea to the Illinois; which arose from the west. In the afternoon it was heard to descend from the east, and that with an incredible quickness; and though the noise seemed to bear on the water, yet without agitating it, or discovering any more wind on the river than before. This frightful noise was only the prelude of a most violent tempest. The hurricane, the most furious ever felt in the province, lasted three days. As it arose from the south-west and north-east, it reached all the settlements which were along the Missisippi; and was felt for some leagues more or less strong, in proportion to the greater or less distance: but in the places, where the force or height of the hurricane passed, it overturned every thing in its way, which was an extent of a large quarter of a league broad; so that one would take it for 


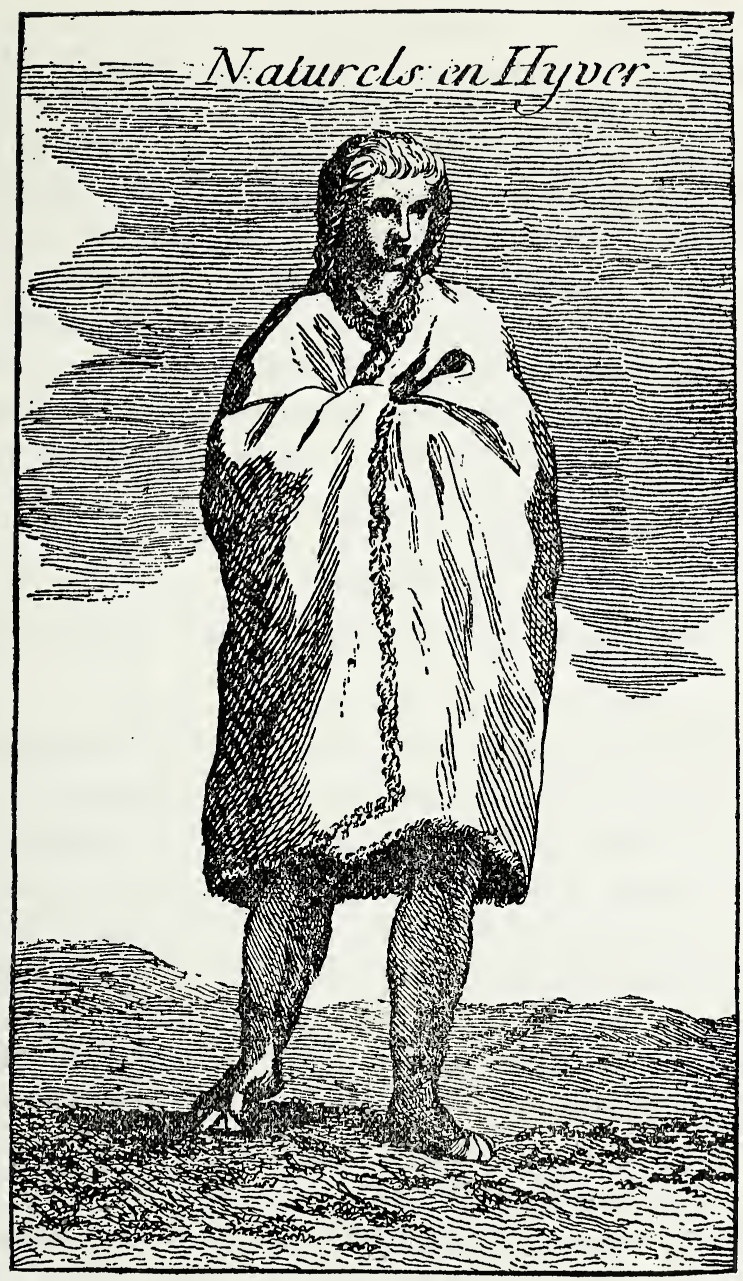

Indian in winter time

an avenue made on purpose, the place where it passed being entirely laid flat, whilst every thing stood upright on each side. The largest trees were torn up by the roots, and their branches broken to pieces and laid flat to the earth, as were also the reeds of the woods. In the meadows, the grass itself, which was then but six inches high, and which is very fine, could not escape, but was trampled, faded, and laid quite flat to the earth. 
The height of the hurricane passed at a league from my habitation; and yet my house, which was built on piles, would have been overturned, had I not speedily propped it with a timber, with the great end in the earth, and nailed to the house with an iron hook seven or eight inches long. Several houses of our post were overturned. But it was happy for us in this colony, that the height of the hurricane passed not directly over any post, but obliquely traversed the Missisippi, over a country intirely uninhabited. As this hurricane came from the south, it so swelled the sea, that the Missisippi flowed back against its current, so as to rise upwards of fifteen feet high.

\section{Chapter VII.}

First War with the Natchez. Cause of the War.

$\mathrm{N}$ the same year, towards the end of summer, we had the first war with the Natchez. The French had settled at the Natchez, without any opposition from these people; so far from opposing them, they did them a great deal of service, and gave them very material assistance in procuring provisions; for those, who were sent by the West India Company with the first fleet, had been detained at New Orleans. Had it not been for the natives, the people must have perished by famine and distress : for, how excellent soever a new country may be, it must be cleared, grubbed up, and sown, and then at least we are to wait the first harvest, or crop. But during all that time people must live, and the company was well apprized of this, as they had sent, with the eight hundred men they had transported to Louisiana, provisions for three years. The grantees and planters, obliged to treat, or truck for provisions with the Natchez, in consequence of that saw their funds wasted, and themselves incapable of forming so considerable a settlement, without this trucking, as necessary, as it was frequent.

However, some benefit resulted from this; namely, that the Natchez, enticed by the facility of trucking for goods, before unknown among them, as fusils, gun-powder, lead, brandy, linen, cloths, and other like things, by means of an exchange of what they abounded with, came to be more and more attached 
to the French; and would have continued very useful friends, had not the little satisfaction which the commandant of Fort Rosalie had given them, for the misbehaviour of one of his soldiers, alienated their minds. This fort covered the settlement of the Natchez, and protected that of St. Catharine, which was on the banks of the rivulet of the Natchez; but both the defence and protection it afforded were very inconsiderable; for this fort was only pallisadoed, open at six breaches, without a ditch, and with a very weak garrison. On the other hand, the houses of the inhabitants, though considerably numerous, were of themselves of no strength; and then the inhabitants, dispersed in the country, each amidst his field, far from affording mutual assistance, as they would had they been in a body, stood each of them, upon any accident, in need of the assistance of others.

A young soldier of Fort Rosalie had given some credit to an old warrior of a village of the Natchez; which was that of the White Apple, each village having its peculiar name: the warrior, in return, was to give him some corn. Towards the beginning of the winter 1723, this soldier lodging near the fort, the old warrior came to see him; the soldier insisted on his corn; the native answered calmly, that the corn was not yet dry enough to shake out the grain; that besides, his wife had been ill, and that he would pay him as soon as possible. The young man, little satisfied with this answer, threatened to cudgel the old man: upon which, this last, who was in the soldier's hut, affronted at this threat, told him, he should turn out, and try who was the best man. On this challenge, the soldier, calling out murder, brings the guard to his assistance. The guard being come, the young fellow pressed them to fire upon the warrior, who was returning to his village at his usual pace; a soldier was imprudent enough to fire: the old man dropt down. The commandant was soon apprized of what happened, and came to the spot; where the witnesses, both French and Natchez, informed him of the fact. Both justice and prudence demanded to take an exemplary punishment of the soldier; but he got off with a reprimand. After this the natives made a litter, and carried off their warrior, who died the 
following night of his wounds, though the fusil was only charged with great shot.

Revenge is the predominant passion of the people in America: so that we ought not to be surprised, if the death of this old warrior raised his whole village against the French. The rest of the nation took no part at first in the quarrel.

The first effect of the resentment of the Natchez fell upon a Frenchman named M. Guenot, whom they surprised returning from the fort to St. Catharine, and upon another inhabitant, whom they killed in his bed. Soon after they attacked, all in a body, the settlement of St. Catharine, and the other below Fort Rosalie. It was at this last I had fixed my abode: I therefore saw myself exposed, like many others, to pay with my goods, and perhaps my life, for the rashness of a soldier, and the too great indulgence of his captain. But as I was already acquainted with the character of the people we had to deal with, I despaired not to save both. I therefore barricadoed myself in my house, and having put myself in a posture of defence, when they came in the night, according to their custom, to surprise me, they durst not attack me.

This first attempt, which I justly imagined was to be followed by another, if not by many such, made me resolve, as soon as day came, to retire under the fort, as all the inhabitants also did, and thither to carry all the provisions I had at my lodge. I could execute only half of my scheme. My slaves having begun to remove the best things, I was scarce arrived under the fort, but the commandant begged I might put myself at the head of the inhabitants, to go to succour St. Catharine. $\mathrm{He}$ had already sent thither all his garrison, reserving only five men to guard the fort; but this succour was not sufficient to relieve the settlement, which the natives in great numbers vigorously straitned.

I departed without delay: we heard the firing at a distance, but the noise ceased as soon as I was come, and the natives appeared to have retired: they had, doubtless, discovered me on my march, and the sight of a reinforcement which I had brought with me, deceived them. The officer who commanded the detachment of the garrison, and whom I relieved, returned 
to the fort with his men; and the command being thus devolved on me, I caused all the Negroes to be assembled, and ordered them to cut down all the bushes; which covering the country, favoured the approach of the enemy, quite to the doors of the houses of that Grant. This operation was performed without molestation, if you except a few shot, fired by the natives from the woods, where they lay concealed on the other side of the rivulet; for the plain round St. Catharine being entirely cleared of every thing that could screen them, they durst not shew themselves any more.

However, the commandant of Fort Rosalie sent to treat with the Stung Serpent; in order to prevail with him to appease that part of his nation, and procure a peace. As that great warrior was our friend, he effectually laboured therein, and hostilities ceased. After I had passed twenty-four hours in St. Catharine, I was relieved by a new detachment from the inhabitants, whom, in my turn, I relieved next day. It was on this second guard, which I mounted, that the village we had been at war with sent me, by their deputies, the calumet or pipe of peace. I at first had some thoughts of refusing it, knowing that this honour was due to the commandant of the fort; and it appeared to me a thing so much the more delicate to deprive him of it, as we were not upon very good terms with each other. However, the evident risk of giving occasion to protract the war, by refusing it, determined me to accept of it; after having, however, taken the advice of those about me; who all judged it proper to treat these people gently, to whom the commandant was become odious.

I asked the deputies, what they would have? They answered, faultering, Peace. "Good, said I; but why bring you the Calumet of Peace to me? It is to the Chief of the Fort you are to carry it, if you wish to have a Peace." "Our orders" said they, "are to carry it first to you, if you choose to receive it by only smoking therein: after which we will carry it to the Chief of the Fort; but if you refuse receiving it, our orders are to return."

Upon this I told them, that I agreed to smoke in their pipe, on condition they would carry it to the Chief of the Fort. 
They then made me an harangue; to which I answered, that it were best to resume our former manner of living together, and that the French and the Red-men should entirely forget what had passed. To conclude, that they had nothing further to do, but to go and carry the Pipe to the Chief of the Fort, and then go home and sleep in peace.

This was the issule of the first war we had with the Natchez, which lasted only three or four days.

The commerce, or truck, was set again on the same footing it had been before; and those who had suffered any damage, now thought only how they might best repair it. Some time after, the Major General arrived from New Orleans, being sent by the Governor of Louisiana to ratify the peace; which he did, and mutual sincerity was restored, and became as perfect as if there had never been any rupture between us.

It had been much to be wished, that matters had remained on so good a footing. As we were placed in one of the best and finest countries of the world; were in strict connection with the natives, from whom we derived much knowledge of the nature of the productions of the country, and of the animals of all sorts, with which it abounds; and likewise reaped great advantage in our traffic for furs and provisions; and were aided by them in many laborious works, we wanted nothing but a profound peace, in order to form solid settlements, capable of making us lay aside all thoughts of Europe: but Providence had otherwise ordered.

The winter which succeeded this war was so severe, that a colder was never remembered. The rain fell in icicles in such quantities as to astonish the oldest Natchez, to whom this great cold appeared new and uncommon.

Towards the autumn of this year I saw a phænomenon which struck the superstitious with great terror: it was in effect so extraordinary, that I never remember to have heard of any thing that either resembled, or even came up to it. I had just supped without doors, in order to enjoy the cool of the evening; my face was turned to the west, and I sat before my table to examine some planets which had already appeared. 


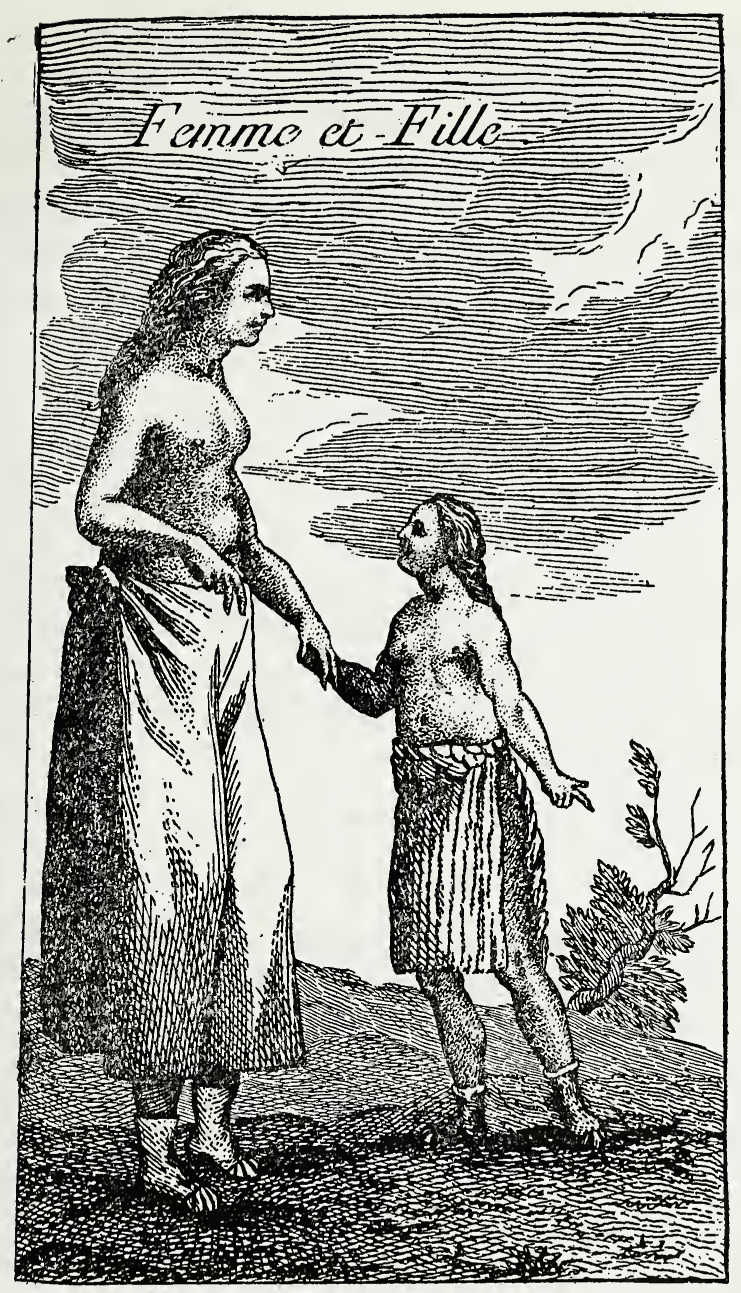

Indian woman and daughter

I perceived a glimmering light, which made me raise my eyes; and immediately I saw, at the elevation of about 45 degrees above the horizon, a light proceeding from the south, of the breadth of three inches, which went off to the north, always spreading itself as it moved, and made itself heard by a whizzing light like that of the largest sky-rocket. I judged by the eye that this light could not be above our atmosphere, and the whizzing noise which I heard confirmed me in that notion. 
When it came in like manner to be about 45 degrees to the north above the horizon, it stopped short, and ceased enlarging itself: in that place it appeared to be twenty inches broad; so that in its course, which had been very rapid, it formed the figure of a trumpet-marine, and left in its passage very lively sparks, shining brighter than those which fly from under a smith's hammer; but they were extinguished almost as fast as they were emitted.

At the north elevation I just mentioned, there issued out with a great noise from the middle of the large end, a ball quite round, and all on fire: this ball was about six inches in diameter; it fell below the horizon to the north, and emitted, about twenty minutes after, a hollow, but very loud noise for the space of a minute, which appeared to come from a great distance. The light began to be weakened to the south, after emitting the ball, and at length disappeared, before the noise of the ball was heard.

\section{Chapter VIII.}

The Governor surprized the Natchez with seven hundred Men. Astonishing Cures performed by the Natives. The Author sends upwards of three hundred Simples to the Company.

M. De Biainville, at the beginning of the winter which followed this phænomenon, arrived very privately at our quarter of the Natchez, his march having been communicated to none but the Commandant of this Post, who had orders to seize all the Natchez that should come to the Fort that day, to prevent the news of his arrival being carried to their countrymen. He brought with him, in regular troops, inhabitants and natives, who were our allies, to the number of seven hundred men.

Orders were given that all our settlers at the Natchez should repair before his door at midnight at the latest: I went thither and mixed with the crowd, without making myself known.

We arrived two hours before day at the settlement of St. Catharine. The Commandant having at length found me out, 
ordered me, in the King's name, to put myself at the head of the settlers among the Natchez, and to take the command upon me; and these he ordered to pay the same obedience to me as to himself. We advanced with great silence towards the village of the Apple. It may be easily seen that all this precaution was taken in order to surprise our enemies, who ought so much the less to expect this act of hostility, as they had fairly made peace with us, and as M. Paillou, Major General, had come and ratified this peace in behalf of the Governor. We marched to the enemy and invested the first hut of the Natchez, which we found separate; the drums, in concert with the fifes, beat the charge; we fired upon the hut, in which were only three men and two women.

From thence we afterwards moved on to the village, that is, several huts that stood together in a row. We halted at three of them that lay near each other, in which between twelve and fifteen Natchez had entrenched themselves. By our manner of proceeding one would have thought that we came only to view the huts. Full of indignation that none exerted himself to fall upon them, I took upon me with my: men to go round and take the enemy in rear. They took to their heels, and I pursued; but we had need of the swiftness of deer to be able to come up with them. I came so near, however, that they threw away their cloaths, to run with the greater speed.

I rejoined our people, and expected a reprimand for having forced the enemy without orders; though I had my excuse ready. But here I was mistaken; for I met with nothing but encomiums.

This war, of which I shall give no further detail, lasted only four days. M. de Biainville demanded the head of an old mutinous Chief of this village; and the natives, in order to obtain a peace, delivered him up.

I happened to live at some distance from the village of the Apple, and very seldom saw any of the people. Such as lived nearer had more frequent visits from them; but after this war, and the peace which followed upon it, I never saw one of them. My neighbours who lived nearer to them saw but a few of them, even a long time after the conclusion of the war. The 
natives of the other villages came but very seldom among us; and indeed, if we could have done well without them, I could have wished to have been rid of them for ever. But we had neither a flesh nor a fish-market; therefore, without them, we must have taken up with what the poultry-yard and kitchengarden furnished; which would have been extremely inconvenient.

I one day stopped the Stung Serpent, who was passing without taking notice of any one. He was brother to the Great Sun, and Chief of the Warriors of the Natchez. I accordingly called to him, and said, "We were formerly friends, are we no longer so?" He answered, Noco; that is, I cannot tell. I replied, "You used to come to my house; at present you pass by. Have you forgot the way; or is my house disagreeable to you? As for me, my heart is always the same, both towards you and all my friends. I am not capable of changing, why then are you changed?"

He took some time to answer, and seemed to be embarrassed by what I said to him. He never went to the fort, but when sent for the Commandant, who put me upon sounding him; in order to discover whether his people still retained any grudge.

He at length broke silence, and told me, "he was ashamed to have been so long without seeing me; but I imagined," said he, "that you were displeased at our nation; because among all the French who were in the war, you were the only one that fell upon us." "You are in the wrong," said I, "to think so. M. de Biainville being our War-chief, we are bound to obey him; in like manner as you, though a Sun, are obliged to kill, or cause to be killed, whomsoever your brother, the Great Sun orders to be put to death. Many other Frenchmen, besides me, sought an opportunity to attack your countrymen, in obedience to the orders of M. de Biainville; and several other Frenchmen fell upon the nearest hut, one of whom was killed by the first shot which the Natchez fired."

He then said: "I did not approve, as you know, the war our people made upon the French to avenge the death of their 
relation, seeing I made them carry the pipe of peace to the French. This you well know, as you first smoked in the pipe yourself. Have the French two hearts, a good one to-day, and to-morrow a bad one? As for my brother and me, we have but one heart and one word. Tell me then, if thou art, as thou sayest, my true friend, what thou thinketh of all this, and shut thy mouth to every thing else. We know not what to think of the French, who, after having begun the war, granted a peace, and offered it of themselves; and then at the time we were quiet, believing ourselves to be at peace, people come to kill us, without saying a word."

"Why," continued he, with an air of displeasure, "did the French come into our country? We did not go to seek them: they asked for land of us, because their country was too little for all the men that were in it. We told them they might take land where they pleased, there was enough for them and for us; that it was good the same sun should enlighten us both, and that we would walk as friends in the same path; and that we would give them of our provisions, assist them to build, and to labour in their fields. We have done so; is not this true? What occasion then had we for Frenchmen? Before they came, did we not live better than we do, seeing we deprive ourselves of a part of our corn, our game, and fish, to give a part to them? In what respect, then, had we occasion for them? Was it for their guns? The bows and arrows which we used, were sufficient to make us live well. Was it for their white, blue, and red blankets? We can do well enough with buffalo skins, which are warmer; our women wrought featherblankets for the winter, and mulberry-mantles for the summer; which indeed were not so beautiful; but our women were more laborious and less vain than they are now. In fine, before the arrival of the French, we lived like men who can be satisfied with what they have; whereas at this day we are like slaves, who are not suffered to do as they please."

To this unexpected discourse I know not what answer another would have made; but I frankly own, that if at my first address he seemed to be confused, I really was so in my turn. "My heart," said I to him, "better understands thy 
reasons than my ears, though they are full of them; and though I have a tongue to answer, my ears have not heard the reasons of $M$. de Biainville, to tell them thee: but I know it was necessary to have the head he demanded, in order to a peace. When our Chiefs command us, we never require the reasons: I can say nothing else to thee. But to shew you that I am always your real friend, I have here a beautiful pipe of peace, which I wanted to carry to my own country. I know you have ordered all your warriors to kill some white eagles, in order to make one, because you have occasion for it. I give it you without any other design than to shew you that I reckon nothing dear to me, when I want to do you a pleasure."

I went to look for it, and I gave it him, telling him, that it was without design; that is, according to them, from no interested motive. The natives put as great a value on a pipe of peace as on a gun. Mine was adorned with tinsel and silver wire: so that in their estimation my pipe was worth two guns. He appeared to be extremely well pleased with it; put it up hastily in his case, squeezed my hand with a smile, and called me his true friend.

The winter was now drawing to a close, and in a little time the natives were to bring us bear-oil to truck. I hoped that by his means I should have of the best preferably to any other; which was the only compensation I expected for my pipe. But I was agreeably disappointed. He sent me a deerskin of bear-oil, so very large that a stout man could hardly carry it, and the bearer told me, that he sent it to me as his true friend, without design. This deer-skin contained thirtyone pots of the measure of the country, or sixty-two pints Paris measure.

Three days after, the Great Sun, his brother, sent me another deer-skin of the same oil, to the quantity of forty pints. The commonest sort sold this year at twenty sols a pint, and I was sure mine was not of the worst kind.

For some days a fistula lacrymalis had come into my left eye, which discharged an humour, when pressed, that portended danger. I shewed it to M. St. Hilaire, an able surgeon, who 
had practised for about twelve years in the Hôtel Dieu at Paris.

He told me it was necessary to use the fire for it; and that, notwithstanding this operation, my sight would remain as good as ever, only my eye would be blood-shot: and that if I did not speedily set about the operation, the bone of the nose would become carious.

These reasons gave me much uneasiness, as having both to fear and to suffer at the same time: however, after I had resolved to undergo the operation, the Grand Sun and his brother came one morning very early, with a man loaded with game, as a present for me.

The Great Sun observed I had a swelling in my eye, and asked me what was the matter with it. I shewed it him, and told him, that in order to cure it, I must have fire put to it: but that I had some difficulty to comply, as I dreaded the consequences of such an operation. Without replying, or in the least apprizing me, he ordered the man who brought the game to go in quest of his physician, and tell him, he waited for him at my house. The messenger and physician made such dispatch, that this last came in an hour after. The Great Sun ordered him to look at my eye, and endeavour to cure me: after examining it, the physician said, he would undertake to cure me with simples and common water. I consented to this with so much the greater pleasure and readiness, as by this treatment I ran no manner of risque.

That very evening the physician came with his simples, all pounded together, and making but a single ball, which he put with the water in a deep bason, he made me bend my head into it, so as the eye affected stood dipt quite open in the water. I continued to do so for eight or ten days, morning and evening; after which, without any other operation, I was perfectly cured, and never after had any return of the disorder.

It is easy from this relation to understand what dextrous physicians the natives of Louisiana are. I have seen them perform surprising cures on Frenchmen; on two especially, who had put themselves under the hands of a French surgeon 
settled at this post. Both patients were about to undergo the grand cure; and after having been under the hands of the surgeon for some time, their heads swelled to such a degree, that one of them made his escape, with as much agility as a criminal would from the hands of justice, when a favourable opportunity offers. He applied to a Natchez physician, who cured him in eight days: his comrade continuing still under the French surgeon, died under his hands three days after the escape of his companion, whom I saw three years after in a state of perfect health.

In the war which I lately mentioned, the Grand Chief of the Tonicas, our allies, was wounded with a ball, which went through his cheek, came out under the jaw, again entered his body at the neck, and pierced through to the shoulder-blade, lodging at last between the flesh and the skin: the wound had its direction in this manner; because when he received it, he happened to be in a stooping posture, as were all his men, in order to fire. The French surgeon, under whose care he was, and who dressed him with great precaution, was an able man, and spared no pains in order to effect a cure. But the physicians of this Chief, who visited him every day, asked the Frenchman what time the cure would take? he answered, six weeks at least: they returned no answer, but went directly and made a litter; spoke to their Chief, and put him on it, carried him off, and treated him in their own manner, and in eight days affected a complete cure.

These are facts well known in the colony. The physicians of the country have performed many other cures, which, if they were to be all related, would require a whole volume apart; but I have confined myself to the three above mentioned, in order to shew that disorders frequently accounted almost incurable, are, without any painful operation, and in a short time, cured by physicians, natives of Louisiana.

The West India Company being informed that this province produces a great many simples, whose virtues, known by the natives, afforded so easy a cure to all sorts of distempers, ordered M. de la Chaise, who was sent from France in quality of Director General of this colony, to cause enquiry to be made 
into the simples proper for physick and for dying, by means of some Frenchmen, who might perhaps be masters of the secrets of the natives. I was pointed out for this purpose to M. de la Chaise, who was but just arrived, and who wrote to me, desiring my assistance in this enquiry; which I gave him with pleasure, and in which I exerted myself to my utmost, because I well knew the Company continually aimed at what might be for the benefit of the colony.

After I thought I had done in that respect, what might give satisfaction to the Company, I transplanted in earth, put into cane baskets, above three hundred simples, with their numbers, and a memorial, which gave a detail of their virtues, and taught the manner of using them. I afterwards understood that they were planted in a botanic garden made for the purpose, by order of the Company.

\section{CHAPTER IX.}

French Settlements, or Posts. The Post at Mobile. The Mouths of the Missisippi. The Situation and Description of New Orleans.

THE Settlement at Mobile was the first seat of the colony in

this province. It was the residence of the Commandant General, the Commissary General, the Staff-officers, \&c. As vessels could not enter the river Mobile, and there was a small harbour at Isle Dauphine, a settlement was made suited to the harbour, with a guard-house for its security: so that these two settlements may be said to have made but one; both on account of their proximity, and necessary connection with each other. The settlement of Mobile, ten leagues, however, from its har. bour, lies on the banks of the river of that name; and Isle Dauphine, over against the mouth of that river, is four leagues from the coast.

Though the settlement of Mobile be the oldest, yet it is far from being the most considerable. Only some inhabitants remained there, the greatest part of the first inhabitants having left it, in order to settle on the river Missisippi, ever since New Orleans became the capital of the colony. That old post is the 
ordinary residence of a King's Lieutenant, a Regulating Commissary, and a Treasurer. The fort, with four bastions, terraced and palisaded, has a garrison.

This post is a check upon the nation of Choctaws, and cuts off the communication of the English with them; it protects the neighbouring nations, and keeps them in our alliance; in fine, it supports our peltry trade, which is considerable with the Choctaws and other nations*.

The same reason which pointed out the necessity of this post, with respect to the Choctaws, also shewed the necessity of building a fort at Tombecbé, to check the English in their ambitious views on the side of the Chicasaws. That fort was built only since the war with the Chicasaws in 1736 .

Near the river Mobile stands the small settlement of the Pasca-Ogoulas; which consists only of a few Canadians, lovers of tranquillity, which they prefer to all the advantages they could reap from commerce. They content themselves with a frugal country life, and never go to New Orleans but for necessaries.

From that settlement quite to New Orleans, by the way of Lake St. Louis, there is no post at present. Formerly, and

* Fort Lewis at Mobile is built upon the river that bears the same name, which falls into the sea opposite to Dauphine island. The fort is about 15 or 16 leagues distant from that island; and is built of brick, fortified with four bastions, in the manner of Vauban, with half-moons, a covered way and glacis. There is a magazine in it, with barracks for the troops of the garrison, which is generally pretty numerous, and a flag for the commandant.

I must own, I never could see for what reason this fort was built, or what could be the use of it. For although it is 120 leagues from the capital, to go down the river, yet it is from thence that they must have every thing that is necessary for the support of the garrison: and the soil is so bad, being nothing but sand, that it produces nothing but pines and firs, with a little pulse, which grows there but very indifferently: so that there are here but very few people. The only advantage of this place is, that the air is mild and healthful, and that it affords a traffick with the Spaniards who are near it. The winter is the most agreeable season, as it is mild, and affords plenty of game. But in summer the heats are excessive; and the inhabitants have nothing hardly to live upon but fish, which are pretty plentiful on the coast, and in the rivers. Dumont, II.80. 
just before the building of the capital, there were the old and new Biloxi: settlements, which have deserved an oblivion as lasting as their duration was short.

To proceed with order and perspicuity, we will go up the Missisippi from its mouth.

Fort Balise is at the entrance of the Missisippi, in $29^{\circ}$ degrees North Latitude, and $286^{\circ} 30^{\prime}$ of Longitude. This fort is built on an isle, at one of the mouths of the Missisippi. Tho' there are but seventeen feet water in the channel, I have seen vessels of five hundred ton enter into it. I know not why this entrance is left so neglected, as we are not in want of able engineers in France, in the hydraulic branch, a part of the mathematics to which I have most applyed myself. I know it is no easy matter so to deepen or hollow the channel of a bar, that it may never after need clearing, and that the expences run high: but my zeal for promoting the advantage of this colony having prompted me to make reflections on those passes, or entrances of the Missisippi, and being perfectly well acquainted both with the country and the nature of the soil, I dare flatter myself, I may be able to accomplish it, to the great benefit of the province, and acquit myself therein with honour, at a small charge, and in a manner not to need repetition*.

I say, fort Balise is built upon an island; a circumstance, I imagine, sufficient to make it understood, that this fort is irregular; the figure and extent of this small island not admitting it to be otherwise.

In going up the Missisippi, we meet with nothing remarkable before we come to the Detour aux Anglois, the English Reach: in that part the river takes a large compass; so that

* Seven leagues above the mouth of the river we meet with two other passes, as large as the middle one by which we entered; one is called the Otter Pass, and the other the East Pass; and they assure me, it is only by this last Pass that ships now go up or down the river, they having entirely deserted the ancient middle pass. Dumont, I. 4.

Many other bays and rivers, not known to our authors, lying along the bay of Mexico, to the westward of the Missisippi, are described by Mr. Coxe, in his account of Carolina, called by the French Louisiana. 
the same wind, which was before fair, proves contrary in this elbow, or reach. For this reason it was thought proper to build two forts at that place, one on each side of the river, to check any attempts of strangers. These forts are more than sufficient to oppose the passage of an hundred sail; as ships can go up the river, only one after another, and can neither cast anchor, nor come on shore to moor.

It will, perhaps, be thought extraordinary that ships cannot anchor in this place. I imagine the reader will be of my opinion, when I tell him, the bottom is only a soft mud, or ooze, almost entirely covered with dead trees, and this for upwards of an hundred leagues. As to putting on shore, it is equally impossible and needless to attempt it; because the place where these forts stand, is but a neck of land between the river and the marshes: now it is impossible for a shallop, or canoe, to come near to moor a vessel, in sight of a fort well guarded, or for an enemy to throw up a trench in a neck of land so soft. Besides, the situation of the two forts is such, that they may in a short time receive succours, both from the inhabitants, who are on the interior edge of the crescent, formed by the river, and from New Orleans, which is very near thereto.

The distance from this place to the capital is reckoned six leagues by water, and the course nearly circular; the winding, or reach, having the figure of a $\mathrm{C}$ almost close. Both sides of the river are lined with houses, which afford a beautiful prospect to the eye; however, as this voyage is tedious by water, it is often performed on horseback by land.

The great difficulties attending the going up the river under sail, particularly at the English Reach, for the reasons mentioned, put me upon devising a very simple and cheap machine, to make vessels go up with ease quite to New-Orleans. Ships are sometimes a month in the passage from Balise to the capital; whereas by my method they would not be eight days, even with a contrary wind; and thus ships would go four times quicker than by towing, or turning it. This machine might be deposited at Balise, and delivered to the vessel, in order to go up the current, and be returned again on its setting sail. It is besides proper to observe, that this machine would be no detri- 
ment to the forts, as they would always have it in their power to stop the vessels of enemies, who might happen to use it.

New Orleans, the capital of the colony, is situated to the East, on the banks of the Missisippi, in $30^{\circ}$ of North Latitude. At my first arrival in Louisiana, it existed only in name; for on my landing I understood $\mathrm{M}$. de Biainville, commandant general, was only gone to mark out the spot; whence he returned three days after our arrival at Isle Dauphine.

He pitched upon this spot in preference to many others, more agreeable and commodious; but for that time this was a place proper enough: besides, it is not every man that can see so far as some others. As the principal settlement was then at Mobile, it was proper to have the capital fixed at a place from which there could be an easy communication with this post: and thus a better choice could not have been made, as the town being on the banks of the Missisippi, vessels, tho' of a thousand ton, may lay their sides close to the shore even at low water; or at most, need only lay a small bridge, with two of their yards, in order to load or unload, to roll barrels and bales, \&c. without fatiguing the ship's crew. This town is only a league from St. John's creek, where passengers take water for Mobile, in going to which they pass Lake St. Louis, and from thence all along the coast; a communication which was necessary at that time.

I should imagine, that if a town was at this day to be built in this province, a rising ground would be pitched upon, to avoid inundations; besides, the bottom should be sufficiently firm, for bearing grand stone edifices.

Such as have been a good way in the country, without seeing stone, or the least pebble, in upwards of a hundred leagues extent, will doubtless say, such a proposition is impossible, as they never observed stone proper for building in the parts they travelled over. I might answer, and tell them, they have eyes, and see not. I narrowly considered the nature of this country, and found quarries in it; and if there were any in the colony I ought to find them, as my condition and profession of architect should have procured me the knowledge of 


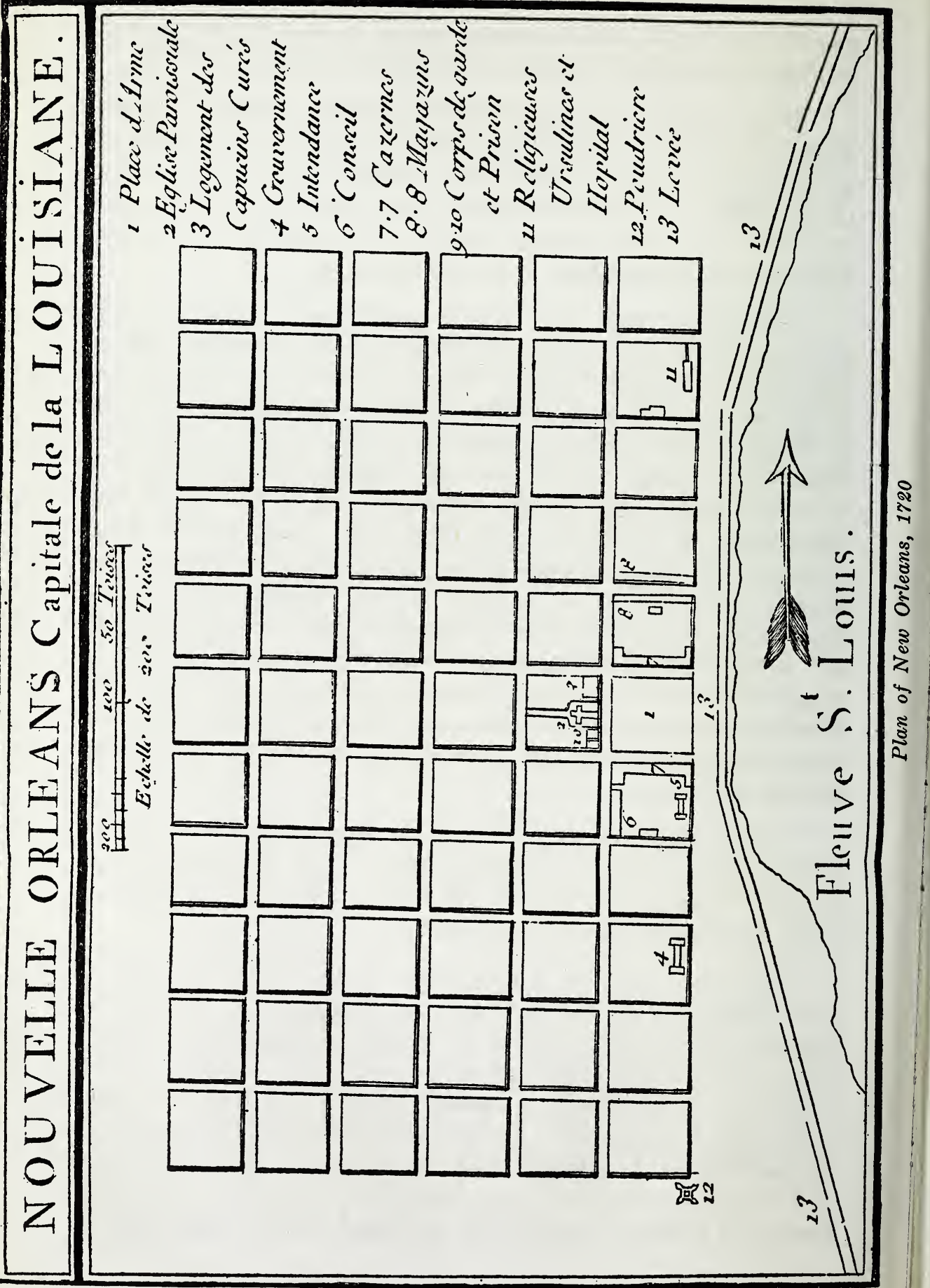


them. After giving the situation of the capital, it is proper I describe the order in which it is built.

The place of arms is in the middle of that part of the town which faces the river; in the middle of the ground of the place of arms stands the parish church, called St. Louis, where the Capuchins officiate, whose house is to the left of the church. To the right stand the prison, or jail, and the guard-house: both sides of the place of arms are taken up by two bodies or rows of barracks. This place stands all open to the river.

All the streets are laid out both in length and breadth by the line, and intersect and cross each other at right angles. The streets divide the town into sixty-six isles; eleven along the river lengthwise, or in front, and six in depth: each of those isles is fifty square toises, and each again divided into twelve emplacements, or compartments, for lodging as many families. The Intendant's house stands behind the barracks on the left; and the magazine, or warehouse-general behind the barracks on the right, on viewing the town from the river side. The Governor's house stands in the middle of that part of the town, from which we go from the place of arms to the habitation of the Jesuits, which is near the town. The house of the Ursulin Nuns is quite at the end of the town, to the right; as is also the hospital of the sick, of which the nuns have the inspection. What I have just described faces the river.

On the banks of the river runs a causey, or mole, as well on the side of the town as on the opposite side, from the English Reach quite to the town, and about ten leagues beyond it; which makes about fifteen or sixteen leagues on each side the river; and which may be travelled in a coach or on horseback, on a bottom as smooth as a table.

The greatest part of the houses is of brick; the rest are of timber and brick.

The length of the causeys, I just mentioned, is sufficient to shew, that on these two sides of the Missisippi there are many habitations standing close together; each making a causey to secure his ground from inundations, which fail not to come every year with the spring: and at that time, if any ships 
happen to be in the harbour of New Orleans, they speedily set sail; because the prodigious quantity of dead wood, or trees torn up by the roots, which the river brings down, would lodge before the ship, and break the stoutest cables.

At the end of St. John's Creek, on the banks of the Lake St. Louis, there is a redoubt, and a guard to defend it.

From this creek to the town, a part of its banks is inhabited by planters; in like manner as are the long banks of another creek: the habitations of this last go under the name of Gentilly.

After these habitations, which are upon the Missisippi quite beyond the Cannes Brulées, Burnt Canes, we meet none till we come to the Oumas, a petty nation so called. This settlement is inconsiderable, tho' one of the oldest next to the capital. It lies on the east of the Missisippi.

The Baton Rouge is also on the east side of the Missisippi, and distant twenty-six leagues from New Orleans: it was formerly the grant of M. Artaguette d'Iron: it is there we see the famous cypress-tree of which a ship-carpenter offered to make two pettyaugres, one of sixteen, the other of fourteen tons. Some one of the first adventurers, who landed in this quarter, happened to say, that tree would make a fine walkingstick, and as cypress is a red wood, it was afterwards called le Baton Rouge. Its height could never be measured, it rises so out of sight.

Two leagues higher up than le Baton Rouge, was the Grant of M. Paris du Vernai. This settlement is called Bayou-Ogoulas, from a nation of that name, which formerly dwelt here. It is on the west side of the Missisippi, and twenty-eight leagues from New Orleans.

At a league on this side of Pointe Coupée, are les Petits Ecores, (little Cliffs) where was the grant of the Marquis de Mezieres. At this grant were a director and under-director; but the surgeon found out the secret of remaining sole master. The place is very beautiful, especially behind les Petits Ecores, where we go up by a gentle ascent. Near these cliffs, a rivulet falls into the Missisippi, into which a spring discharges its waters, which so attract the buffalos, that they are very often 
found on its banks. 'Tis a pity this ground was deserted; there was enough of it to make a very considerable grant: a good water-mill might be built on the brook I just mentioned.

At forty leagues from New Orleans lies a la Pointe Coupée, so called, because the Missisippi made there an elbow or winding, and formed the figure of a circle, open only about an hundred and odd toises, thro' which it made itself a shorter way, and where all its water runs at present. This was not the work of nature alone: two travellers, coming down the Missisippi, were forced to stop short at this place; because they observed at a distance the surff, or waves, to be very high, the wind beating against the current, and the river being out, so that they durst not venture to proceed. Just by them passed a rivulet, caused by the inundation, which might be a foot deep, by four or five feet broad, more or less. One of the travellers, seeing himself without any thing to do, took his fusil and followed the course of this rivulet, in hopes of killing some game. He had not gone an hundred toises, before he was put into a very great surprize, on perceiving a great opening, as when one is just getting out of a thick forest. He continues to advance, sees a large extent of water, which he takes for a lake; but turning on his left, he espies les Petits Ecores, just mentioned, and by experience he knew, he must go ten leagues to get thither: Upon this he knew, these were the waters of the river. He runs to acquaint his companion: this last wants to be sure of it: certain as they are both of it, they resolve, that it was necessary to cut away the roots, which stood in the passage, and to level the more elevated places. They attempted at length to pass their pettyaugre through, by pushing it before them. They succeeded beyond their expectation; the water which came on, aided them as much by its weight as by its depth, which was increased by the obstacle it met in its way: and they saw themselves in a short time in the Missisippi, ten leagues lower down than they were an hour before; or than they would have been, if they had followed the bed of the river, as they were formerly constrained to do.

This little labour of our travellers moved the earth; the roots being cut away in part, proved no longer an obstacle to 
the course of the water; the slope or descent in this small passage was equal to that in the river for the ten leagues of the compass it took; in fine, nature, though feebly aided, performed the rest. The first time I went up the river, its entire body of water passed through this part; and though the channel was only made six years before, the old bed was almost filled with the ooze, which the river had there deposited; and I have seen trees growing there of an astonishing size, that one might wonder how they should come to be so large in so short a time.

In this spot, which is called la Pointe Coupée, the Cutpoint, was the Grant of M. de Meuse, at present one of the most considerable posts of the colony, with a fort, a garrison, and an officer to command there. The river is on each side lined with inhabitants, who make a great deal of tobacco. There an Inspector resides, who examines and receives it, in order to prevent the merchants being defrauded. The inhabitants of the west side have high lands behind them, which form a very fine country, as I have observed above.

Twenty leagues above this Cut-point, and sixty leagues from New Orleans, we meet with the Red River. In an island formed by that river, stands a French post, with a fort, a garrison, its commandant and officers. The first inhabitants who settled there, were some soldiers of that post, discharged after their time of serving was expired, who set themselves to make tobacco in the island. But the fine sand, carried by the wind upon the leaves of the tobacco, made it of a bad quality, which obliged them to abandon the island and settle on the continent, where they found a good soil, on which they made better tobacco. This post is called the Nachitoches, from a nation of that name, settled in the neighbourhood. At this post M. de St. Denis commanded.

Several inhabitants of Louisiana, allured thither by the hopes of making soon great fortunes, because distant only seven leagues from the Spaniards, imagined the abundant treasures of New Mexico would pour in upon them. But in this they happened to be mistaken; for the Spanish post, called the Adaïes, has less money in it than the poorest village in Europe: the Spaniards being ill clad, ill fed, and always ready to buy 
goods of the French on credit: which may be said in general of all the Spaniards of New Mexico, amidst all their mines of gold and silver. This we are well informed of by our merchants, who have dealt with the Spaniards of this post, and found their habitations and way of living to be very mean, and more so than those of the French.

From the confluence of this Red River, in going up the Missisippi, as we have hitherto done, we find, about thirty leagues higher up, the post of the Natchez.

Let not the reader be displeased at my saying often, nearly, or about so many leagues: we can ascertain nothing justly as to the distances in a country where we travel only by water. Those who go up the Missisippi, having more trouble, and taking more time than those who go down, reckon the route more or less long, according to the time in which they make their voyage; besides, when the water is high, it covers passes, which often shorten the way a great deal.

The Natchez are situate in about $32^{\circ}$ odd minutes of north latitude, and $280^{\circ}$ of longitude. The fort at this post stands two hundred feet perpendicular above low-water mark. From this fort the point of view extends west of the Missisippi quite to the horizon, that is, on the side opposite to that where the fort stands, though the west side be covered with woods, because the foot of the fort stands much higher than the trees. On the same side with the fort, the country holds at a pretty equal height, and declines only by a gentle and almost imperceptible slope, insensibly losing itself from one eminence to another.

The nation which gave name to this post, inhabited this very place at a league from the landing-place on the Missisippi, and dwelt on the banks of a rivulet, which has only a course of four or five leagues to that river. All travellers who passed and stopped here, went to pay a visit to the natives, the Natchez. The distance of the league they went to them is through so fine and good a country, the natives themselves were so obliging and familiar, and the women so amiable, that all travellers failed not to make the greatest encomiums both on the country, and on the native inhabitants. 
The just commendations bestowed upon them drew thither inhabitants in such numbers, as to determine the Company to give orders for building a fort there, as well to support the French already settled, and those who should afterwards come thither, as to be a check on that nation. The garrison consisted only of between thirty and forty men, a Captain, a Lieutenant, Under Lieutenant, and two Serjeants.

The Company had there a warehouse for the supply of the inhabitants, who were daily increasing in spite of all the efforts of one of the principal Superiors, who put all imaginable obstacles in the way: and notwithstanding the progress this settlement made, and the encomiums bestowed upon it, and which it deserved, God in his providence gave it up to the rage of its enemies, in order to take vengeance of the sins committed there; for without mentioning those who escaped the general massacre, there perished of them upwards of five hundred.

Forty leagues higher up than the Natchez, is the river Yasou. The Grant of M. le Blanc, Minister, or Secretary at War, was settled there, four leagues from the Missisippi, as you go up this little river*. There a fort stands, with a company of men, commanded by a Captain, a Lieutenant, UnderLieutenant, and two Serjeants. This company, together with the servants, were in the pay of this Minister.

This post was very advantageously situated, as well for the goodness of the air as the quality of the soil, like to that of the Natchez, as for the landing-place, which was very commodious, and for the commerce with the natives, if our people but knew how to gain and preserve their friendship. But the neighbourhood of the Chicasaws, ever fast friends of the English, and ever instigated by them to give us uneasiness, almost cut off any hopes of succeeding. This post was on these accounts threatened with utter ruin, sooner or later; as actually happened in 1722, by means of those wretched Chicasaws;

* The village of the Indians (Yasous) is a league from this settlement; and on one side of it there is a hill, on which they pretend that the English formerly had a fort; accordingly there are still some traces of it to be seen. Dumont, II.296. 
who came in the night and murdered the people in the settlements that were made by two serjeants out of the fort. But a boy who was scalped by them was cured, and escaped with life.

Sixty miles higher up than the Yasouz, and at the distance of two hundred leagues from New Orleans, dwell the Arkansas, to the west of the Missisippi. At the entrance of the river which goes by the name of that nation, there is a small fort, which defends that post, which is the second of the colony in point of time.

It is a great pity so good and fine a country is distant from the sea upwards of two hundred leagues. I cannot omit mentioning, that wheat thrives extremely well here, without our being obliged ever to manure the land; and I am so prepossessed in its favour, that I persuade myself the beauty of the climate has a great influence on the character of the inhabitants, who are at the same time very gentle and very brave. They have ever had an inviolable friendship for the French, uninfluenced thereto either by fear or views of interest; and live with the French near them as brethren rather than as neighbours.

In going from the Arkansas to the Illinois, we meet with the river St. Francis, thirty leagues more to the north, and on the west side of the Missisippi. There a small fort has been built since my return to France. To the East of the Missisippi, but more to the north, we also meet, at about thirty leagues, the river Margot, near the steep banks of Prud'homme: there a fort was also built, called Assumption, for undertaking an expedition against the Chicasaws, who are nearly in the same latitude. These two forts, after that expedition, were entirely demolished by the French, because they were thought to be no longer necessary. It is, however, probable enough, that this fort Assumption would have been a check upon the Chicasaws, who are always roving in those parts. Besides, the steep banks of Prud'homme contain iron and pit-coal. On the other hand, the country is very beautiful, and of an excellent quality, abounding with plains and meadows, which favour the excursions of the Chicasaws, and which they will ever continue to make upon us, till we have the address to divert them from their commerce with the English. 
We have no other French settlements to mention in Louisiana, but that of the Illinois; in which part of the colony we had the first fort. At present the French settlement here is on the banks of the Missisippi, near one of the villages of the Illinois*. That post is commanded by one of the principal officers; and M. de Bois-Briant, who was lieutenant of the king, has commanded at it.

Many French inhabitants both from Canada and Europe live there at this day; but the Canadians make three-fourths at least. The Jesuits have the Cure there, with a fine habitation and a mill; in digging the foundation of which last, a quarry of orbicular flat stones was found, about two inches in diameter, of the shape of a buffoon's cap, with six sides, whose groove was set with small buttons of the size of the head of a minikin or small pin. Some of these stones were bigger, some smaller; between the stones which could not be joined, there was no earth found.

The Canadians, who are numerous in Louisiana, are most of them at the Illinois. This climate, doubtless, agrees better with them, because nearer Canada than any other settlement of the colony. Besides, in coming from Canada, they always pass through this settlement; which makes them choose to continue here. They bring their wives with them, or marry the French or India women. The ladies even venture to make this long and painful voyage from Canada, in order to end their days in a country which the Canadians look upon as a terrestrial paradise $\dagger$.

* They have, or had formerly, other settlenents hereabouts, at Kaskaskies, fort Chartres, Tamaroas, and on the river Marameg, on the west side of the Missisippi, where they found those mines that gave rise to the Missisippi scheme in 1719. In 1742, when John Howard, Sallee and others, were sent from Virginia to view those countries, they were made prisoners by the French; who came from a settlement they had on an island in the Missisippi, a little above the Ohio, where they made salt, lead, \&c. and went from thence to New Orleans, in a fleet of boats and canoes, guarded by a large armed schooner. Report of the Government of Virginia.

$\dagger$ It is this that has made the French undergo so many long and perilous voyages in North-America, upwards of two thousand miles, against cur- 


\section{Chapter X.}

The Voyages of the French to the Missouris, Canzas, and Padoucas. The Settlements they in vain attempted to make in those Countries; with a Description of an extraordinary Phænomenon.

THE Padoucas, who lie west by northwest of the Missouris, 1 happened at that time to be at war with the neighbouring nations, the Canzas, Othouez, Aiaouez, Osages, Missouris, and Panimahas, all in amity with the French. To conciliate a peace between all these nations and the Padoucas, M. de Bourgmont sent to engage them, as being our allies, to accompany him on a journey to the Padoucas, in order to bring about a general pacification, and by that means to facilitate the traffick or truck between them and us, and conclude an alliance with the Padoucas.

For this purpose M. de Bourgmont set out on the $3 d$ of July, 1724, from Fort Orleans, which lies near the Missouris, a nation dwelling on the banks of the river of that name, in order to join that people, and then to proceed to the Canzas, where the general rendezvous of the several nations was appointed.

M. de Bourgmont was accompanied by an hundred Missouris, commanded by their Grand Chief, and eight other Chiefs of war, and by sixty-four Osages, commanded by four Chiefs of war, besides a few Frenchmen. On the sixth he joined the Grand Chief, six other Chiefs of war, and several Warriors of the Canzas, who presented him the Pipe of Peace,

rents, cataracts, and boisterous winds on the lakes, in order to get to this settlement of the Illinois, which is nigh to the Forks of the Missisippi, the most important place in all the inland parts of North-America, to which the French will sooner or later remove from Canada; and there erect another Montreal, that will be much more dangerous and prejudicial to us, than ever the other in Canada was. They will here be in the midst of all their old friends and allies, and much more convenient to carry on a trade with them, to spirit them up against the English, \&c. than ever they were at Montreal. To this settlement, where they likewise are not without good hopes of finding mines, the French will for ever be removing, as long as any of them are left in Canada. 
and performed the honours customary on such occasions, to the Missouris and Osages.

On the 7 th they passed through extensive meadows and woods, and arrived on the banks of the river Missouri, over against the village of the Canzas.

On the 8th the French crossed the Missouri in a pettyaugre, the Indians on floats of cane, and the horses were swam over. They landed within a gun-shot of the Canzas, who flocked to receive them with the Pipe; their Grand Chief, in the name of the nation, assuring $M$. de Bourgmont that all their warriors would accompany him in his journey to the Padoucas, with protestations of friendship and fidelity, confirmed by smoking the Pipe. The same assurances were made him by the other Chiefs, who entertained him in their huts, and* rubbed him over and his companions.

On the 9th M. de Bourgmont dispatched five Missouris to acquaint the Othouez with his arrival at the Canzas. They returned on the 10th, and brought word that the Othouez promised to hunt for him and his Warriors, and to cause provisions to be dried for the journey; that their Chief would set out directly, in order to wait on M. de Bourgmont, and carry him the word of the whole nation.

The Canzas continued to regale the French; brought them also great quantities of grapes, of which the French made a good wine.

On the 24th of July, at six in the morning, this little army set out, consisting of three hundred Warriors, including the Chiefs of the Canzas, three hundred women, about five hundred young people, and at least three hundred dogs. The women carried considerable loads, to the astonishment of the French, unaccustomed to such a sight. The young women also were well loaded for their years; and the dogs were made to trail a part of the baggage, and that in the following manner: the back of the dog was covered with a skin, with its pile on, then the dog was girthed round, and his breast-leather put on; and

* It is thus they express their joy and caresses, at the sight of a person they respect. 
taking two poles of the thickness of one's arm, and twelve feet long, they fastened their two ends half a foot asunder, laying on the dog's saddle the thong that fastened the two poles; and to the poles they also fastened, behind the dog, a ring or hoop, lengthwise, on which they laid the load.

On the 28th and 29th the army crossed several brooks and small rivers, passed through several meadows and thickets; meeting every where on their way a great deal of game.

On the 30th M. de Bourgmont, finding himself very ill, was obliged to have a litter made, in order to be carried back to Fort Orleans till he should recover. Before his departure he gave orders about two Padouca slaves whom he had ransomed, and was to send before him to that nation, in order to ingratiate himself by this act of generosity. These he caused to be sent by one Gaillard, who was to tell their nation, that M. de Bourgmont, being fallen ill on his intended journey to their country, was obliged to return home; but that as soon as he got well again, he would resume his journey to their country, in order to procure a general peace between them and the other nations.

On the evening of the same day arrived at the camp the Grand Chief of the Othouez: who acquainted M. de Bourgmont, that a great part of his Warriors waited for him on the road to the Padoucas, and that he came to receive his orders; but was sorry to find him ill.

At length, on the 4th of August, M. de Bourgmont set out from the Canzas in a pettyaugre, and arrived the 5th at Fort Orleans.

On the 6th of September, M. de Bourgmont, who was still at Fort Orleans, was informed of the arrival of the two Padouca slaves on the $25 \mathrm{~h}$ of August at their own nation; and that meeting on the way a body of Padouca hunters, a day's journey from their village, the Padouca slaves made the signal of their nation, by throwing their mantles thrice over their heads: that they spoke much in commendation of the generosity of M. de Bourgmont, who had ransomed them: told all he had done in order to a general pacification: in fine, extolled the French to such a degree, that their discourse, held in pres- 
ence of the Grand Chief and of the whole nation, diffused an universal joy that Gaillard told them, the flag they saw was the symbol of Peace, and the word of the Sovereign of the French: that in a little time the several nations would come to be like brethren, and have but one heart.

The Grand Chief of the Padoucas was so well assured that the war was now at an end, that he dispatched twenty Padoucas with Gaillard to the Canzas, by whom they were extremely well received. The Padoucas, on their return home, related their good reception among the Canzas; and as a plain and real proof of the pacification meditated by the French, brought with them fifty of the Canzas and three of their women; who, in their turn, were received by the Padoucas with all possible marks of friendship.

Though M. de Bourgmont was but just recovering of his illness; he, however, prepared for his departure, and on the 20 th of September actually set out from Fort Orleans by water, and arrived at the Canzas on the 27 th.

Gaillard arrived on the 2nd of October at the camp of the Canzas, with three Chiefs of war, and three Warriors of the Padoucas, who were received by $M$. de Bourgmont with flag displayed, and other testimonies of civility, and had presents made them of several goods, proper for their use.

On the 4th of October arrived at the Canzas the Grand Chief, and seven other Chiefs of war of the Othouez; and next day, very early, six Chiefs of war of the Aiaouez.

M. de Bourgmant assembled all the Chiefs present, and setting them round a large fire made before his tent, rose up, and addressing himself to them, said, he was come to declare to them, in the name of his Sovereign, and of the Grand French Chief in the country*, that it was the will of his Sovereign, they should all live in peace for the future, like brethren and friends, if they expected to enjoy his love and protection: and since, says he, you are here all assembled this day, it is good you conclude a peace, and all smoke in the same pipe.

* The Governor of Louisiana. 
The Chiefs of these different nations rose up to a man, and said with one consent, they were well satisfied to comply with his request; and instantly gave each other their pipes of peace.

After an entertainment prepared for them, the Padoucas sung the songs, and danced the dances of peace; a kind of pantomimes, representing the innocent pleasures of peace.

On the 6th of October, M. de Bourgmont caused three lots of goods to be made out; one for the Othouez, one for the Aiaouez, and one for the Panimahas, which last arrived in the mean time; and made them all smoke in the same pipe of peace.

On the 8th M. de Bourgmont set out from the Canzas with all the baggage, and the flag displayed, at the head of the French and such Indians as he had pitched on to accompany him, in all forty persons. The goods intended for presents were loaded on horses. As they set out late, they travelled but five leagues, in which they crossed a small river and two brooks, in a fine country, with little wood.

The same day Gaillard, Quenel, and two Padoucas were dispatched to acquaint their nation with the march of the French. That day they travelled ten leagues, crossed one river and two brooks.

The 10th they made eight leagues, crossed two small rivers and three brooks. To their right and left they had several small hills, on which one could observe pieces of rock even with the ground. Along the rivers there is found a slate, and in the meadows, a reddish marble, standing out of the earth, one, two, and three feet; some pieces of it upwards of six feet in diameter.

The 11th they passed over several brooks and a small river, and then the river of the Canzas, which had only three feet water. Further on, they found several brooks, issuing from the neighbouring little hills. The river of the Canzas runs directly from west to east, and falls into the Missouri; is very great in floods, because, according to the report of the Padoucas, it comes a great way off. The woods, which border this river, afford a retreat to numbers of buffaloes and other game. On the left were seen great eminences, with hanging rocks. 
The 12th of October, the journey, as the preceding day, was extremely diversified by the variety of objects. They crossed eight brooks, beautiful meadows, covered with herds of elks and buffaloes. To the right the view was unbounded, but to the left small hills were seen at a distance, which from time to time presented the appearance of ancient castles.

The 13th, on their march they saw the meadows covered almost entirely with buffaloes, elks and deer; so that one could scarce distinguish the different herds, so numerous and so intermixed they were. The same day they passed through a wood almost two leagues long, and a pretty rough ascent; a thing which seemed extraordinary, as till then they only met with little groves, the largest of which scarce contained an hundred trees, but straight as a cane; groves too small to afford a retreat to a quarter of the buffaloes and elks seen there.

The 14th the march was retarded by ascents and descents; from which issued many springs of an extreme pure water, forming several brooks, whose waters uniting make little rivers that fall into the river of the Canzas: and doubtless it is this multitude of brooks which traverse and water these meadows, extending a great way out of sight, that invite those numerous herds of buffaloes.

The 15th they crossed several brooks and two little rivers. It is chiefly on the banks of the waters that we find those enchanting groves, adorned with grass underneath, and so clear of underwood, that we may there hunt down the stag with ease.

The 16th they continued to pass over a similar landscape, the beauties of which were never cloying. Besides the larger game, these groves afforded also a retreat to flocks of turkeys.

The 17th they made very little way, because they wanted to get into the right road, from which they had strayed the two preceding days, which they at length recovered; and, at a small distance from their camp, saw an encampment of the Padoucas, which appeared to have been quitted only about eight days before. This yielded them so much the more pleasure, as it shewed the nearness of that nation, which made them encamp, after having travelled only six leagues, in order 
to make signals from that place, by setting fire to the parts of the meadows which the general fire had spared. In a little time after the signal was answered in the same manner; and confirmed by the arrival of two Frenchmen, who had orders given them to make the signals.

On the 18th they met a little river of brackish water; on the banks of which they found another encampment of the Padoucas, which appeared to have been abandoned but four days before: at half a league further on, a great smoke was seen to the west, at no great distance off, which was answered by setting fire to the parts of the meadows, untouched by the general fire.

About half an hour after, the Padoucas were observed coming at full gallop with the flag which Gaillard had left them on his first journey to their country. M. de Bourgmont instantly ordered the French under arms, and at the head of his people thrice saluted these strangers with his flag, which they also returned thrice, by raising their mantles as many times over their heads.

After this first ceremony, M. de Bourgmont made them all sit down and smoke in the Pipe of Peace. This action, being the seal of the peace, diffused a general joy, accompanied with loud acclamations.

The Padoucas, after mounting the French and the Indians who accompanied them, on their horses, set out for their camp: and after a journey of three leagues, arrived at their encampment; but left a distance of a gun-shot between the two camps.

The day after their arrival at the Padoucas, M. de Bourgmont caused the goods allotted for this nation to be unpacked, and the different species parcelled out, which he made them all presents of*.

After which M. de Bourgmont sent for the Grand Chief and other Chiefs of the Padoucas, who came to the camp to the number of two hundred: and placing himself between them and

* Red and blue Limburgs, shirts, fusils, sabres, gun-powder, ball, musket-flints, gunscrews, mattocks, hatchets, looking-glasses, Flemish knives, wood cutters knives, clasp-knives, scissars, combs, bells, awls, needles, drinking glasses, brass-wire, boxes, rings, \&c. 
the goods thus parcelled and laid out to view, told them, he was sent by his Sovereign to carry them the word of peace, this flag, and these goods, and to exhort them to live as brethren with their neighbours the Panimahas, Aiaouez, Othouez, Canzas, Missouris, Osages, and Illinois, to traffick and truck freely together, and with the French.

He at the same time gave the flag to the Grand Chief of the Padoucas, who received it with demonstrations of respect, and told him, I accept this flag, which you present to me on the part of your Sovereign: we rejoice at our having peace with all the nations you have mentioned; and promise in the name of our nation never to make war on any of your allies; but receive them, when they come among us, as our brethren; as we shall, in like manner, the French, and conduct them, when they want to go to the Spaniards, who are but twelve days journey from our village, and who truck with us in horses, of which they have such numbers, they know not what to do with them; also in bad hatchets of a soft iron, and some knives, whose points they break off, lest we should use them one day against themselves. You may command all my Warriors; I can furnish you with upwards of two thousand. In my own, and in the name of my whole nation, I entreat you to send some Frenchmen to trade with us; we can supply them with horses, which we truck with the Spaniards for buffalo-mantles, and with great quantities of furs.

Before I quit the Padoucas, I shall give a summary of their manners; it may not, perhaps, be disagreeable to know in what respects they differ from other Indian nations*.

The Padoucas, who live at a distance from the Spaniards, cultivate no grain, and live only on hunting. But they are not to be considered as a wandering nation, tho' employed in hunting winter and summer; seeing they have large villages, consisting of a great number of cabins, which contain very numerous families: these are their permanent abodes; from which a

* The Author should likewise have informed us of the fate of those intended settlements of the French, which Dumont tells us were destroyed, and all the French murdered by the Indians, particularly among the Missouris; which is confirmed below in book II. ch. 7 . 
hundred hunters set out at a time with their horses, their bows, and a good stock of arrows. They go thus two or three days journey from home, where they find herds of buffaloes, the least of which consists of a hundred head. They load their horses with their baggage, tents and children, conducted by a man on horseback: by this means the men, women, and young people travel unencumbered and light, without being fatigued by the journey. When come to the hunting-spot, they encamp near a brook, where there is always wood; the horses they tie by one of their fore-feet with a string to a stake or bush.

Next morning they each of them mount a horse, and proceed to the first herd, with the wind at their back, to the end the buffaloes may scent them, and take to flight, which they never fail to do, because they have a very quick scent. Then the hunters pursue them close at an easy gallop, and in a crescent, or half ring, till they hang out the tongue through fatigue, and can do no more than just walk: the hunters then dismount, point a dart at the extremity of the shoulder, and kill each of them one cow, sometimes more: for, as I said above, they never kill the males. Then they flay them, take out the entrails, and cut the carcasse in two; the head, feet, and entrails they leave to the wolves and other carnivorous animals: the skin they lay on the horse, and on that the flesh, which they carry home. Two days after they go out again; and then they bring home the meat stript from the bones; the women and young people dress it in the Indian fashion; while the men return for some days longer to hunt in the same manner. They carry home their dry provisions, and let their horses rest for three or four days: at the end of which, those who remained in the village, set out with the others to hunt in the like manner; which has made ignorant travellers affirm this people was a wandering nation.

If they sow little or no maiz, they as little plant any citruis, never any tobacco; which last the Spaniards bring them in rolls, along with the horses they truck with them for buffalomantles.

The nation of the Padoucas is very numerous, extends almost two hundred leagues, and they have villages quite close 
to the Spaniards of New Mexico. They are acquainted with silver, and made the French understand they worked at the mines. The inhabitants of the villages at a distance from the Spaniards, have knives made of fire-stone, (pierre de feu,) of which they also make hatchets; the largest to fell middling and little trees with; the less, to flay and cut up the beasts they kill.

These people are far from being savage, nor would it be a difficult matter to civilize them; a plain proof they have had long intercourse with the Spaniards. The few days the French stayed among them, they were become very familiar, and would fain have M. de Bourgmont leave some Frenchmen among them; especially they of the village at which the peace was concluded with the other nations. This village consisted of an hundred and forty huts, containing about eight hundred warriors, fifteen hundred women, and at least two thousand children, some Padoucas having four wives. When they are in want of horses, they train up great dogs to carry their baggage.

The men for the most part wear breeches and stockings all of a piece, made of dressed skins, in the manner of the Spaniards: the women also wear petticoats and bodices all of a piece, adorning their waists with fringes of dressed skins.

They are almost without any European goods among them, and have but a faint knowledge of them. They knew nothing of fire-arms before the arrival of M. de Bourgmont; were much frighted at them; and on hearing the report, quaked and bowed their heads.

They generally go to war on horseback, and cover their horses with dressed leather, hanging down quite round, which secures them from darts. All we have hitherto remarked is peculiar to this people, besides the other usages they have in common with the nations of Louisiana.

On the 22nd of October, M. de Bourgmont set out from the Padoucas, and travelled only five leagues that day: the 23d, and the three following days, he travelled in all forty leagues: the 27th, six leagues: the 28th, eight leagues: the 29th, six leagues; and the 30th, as many: the 31st, he travelled only four leagues; and that day arrived within half a league of the Canzas. From the Padoucas to the Canzas, proceeding always 
east, we may now very safely reckon sixty-five leagues and a half. The river of the Canzas is parallel to this route.

On the 1st of November they all arrived on the banks of the Missouri. M. de Bourgmont embarked the $2 d$ on a canoe of skins; and at length, on the 5 th of November, arrived at Fort Orleans.

I shall here subjoin the description of one of these canoes. They choose for the purpose branches of a white and supple wood, such as poplar; which are to form the ribs or curves, and are fastened on the outside with three poles, one at bottom and two on the sides, to form the keel; to these curves two other stouter poles are afterwards made fast, to form the gunnels; then they tighten these sides with cords, the length of which is in proportion to the intended breadth of the canoe: after which they tie fast the ends. When all the timbers are thus disposed, they sew on the skins, which they take care previously to soak a considerable time to render them manageable.

From the account of this journey, extracted and abridged from M. de Bourgmont's Journal, we cannot fail to observe the care and attention necessary to be employed in such enterprizes; the prudence and policy requisite to manage the natives, and to behave with them in an affable manner.

If we view these nations with an eye to commerce, what advantages might not be derived from them, as to furs? A commerce not only very lucrative, but capable of being carried on without any risque; especially if we would follow the plan I am to lay down under the article Commerce.

The relation of this journey shews, moreover, that Louisiana maintains its good qualities throughout; and that the natives of North America derive their origin from the same country, since at bottom they all have the same manners and usages, as also the same manner of speaking and thinking.

I, however, except the Natchez, and the people they call their brethren, who have preserved festivals and ceremonies, which clearly shew they have a far nobler origin. Besides, the richness of their language distinguishes them from all those other people that come from Tartary; whose language, on the 
contrary, is very barren: but if they resemble the others in certain customs, they were constrained thereto from the ties of a common society with them, as in their wars, embassies, and in every thing that regards the common interests of these nations.

Before I put an end to this chapter, I shall relate an extraordinary phænomenon which appeared in Louisiana.

Towards the end of May 1726, the sun was then concealed for a whole day by large clouds, but very distinct one from another; they left but little void space between, to permit the view of the azure sky, and but in very few places: the whole day was very calm; in the evening especially these clouds were entirely joined; no sky was to be seen; but all the different configurations of the clouds were distinguishable: I observed they stood very high above the earth.

The weather being so disposed, the sun was preparing to set. I saw him in the instant he touched the horizon, because there was a little clear space between that and the clouds. A little after, these clouds turned luminous, or reflected the light: the contour or outlines of most of them seemed to be bordered with gold, others but with a faint tincture thereof. It would be a very difficult matter to describe all the beauties which these different colourings presented to the view: but the whole together formed the finest prospect I ever beheld of the kind.

I had my face turned to the east; and in the little time the sun formed this decoration, he proceeded to hide himself more and more; when sufficiently low, so that the shadow of the earth could appear on the convexity of the clouds, there was observed as if a veil, stretched north to south, had concealed or removed the light from off that part of the clouds which extended eastwards, and made them dark, without hindering their being perfectly well distinguished; so that all on the same line were partly luminous, partly dark.

This very year I had a strong inclination to quit the post at the Natchez, where I had continued for eight years. I had taken that resolution, notwithstanding my attachment to that 
settlement. I sold off my effects and went down to New Orleans, which I found greatly altered by being entirely built. I intended to return to Europe; but M. Perier, the Governor, pressed me so much, that I accepted the inspection of the plantation of the Company; which, in a little time after, became the King's.

\section{ChAPTER XI.}

The War with the Chitimachas. The Conspiracy of the Negroes against the French. Their Execution.

BEFORE my arrival in Louisiana, we happened to be at war with the nation of the Chitimachas; owing to one of that people, who being gone to dwell in a bye-place on the banks of the Missisippi, had assassinated M. de St. Come, a Missionary of that colony; who, in going down the river, imagined he might in safety retire into this man's hut for a night. M. de Biainville charged the whole nation with this assassination; and in order to save his own people, caused them to be attacked by several nations in alliance with the French.

Prowess is none of the greatest qualities of the Indians, much less of the Chitimachas. They were therefore worsted, and the loss of their bravest warriors constrained them to sue for peace. This the Governor granted, on condition that they brought him the head of the assassin; which they accordingly did, and concluded a peace by the ceremony of the Calumet, hereafter described.

At the time the succours were expected from France, in order to destroy the Natchez, the negroes formed a design to rid themselves of all the French at once, and to settle in their room, by making themselves masters of the capital, and of all the property of the French. It was discovered in the following manner.

A female negroe receiving a violent blow from a French soldier for refusing to obey him, said in her passion, that the French should not long insult negroes. Some Frenchmen overhearing these threats, brought her before the Governor, 
who sent her to prison. The Judge Criminal not being able to draw any thing out of her, I told the Governor, who seemed to pay no great regard to her threats, that I was of opinion, that a man in liquor, and a woman in passion, generally speak truth. It is therefore highly probable, said I that there is some truth in what she said: and if so, there must be some conspiracy ready to break out, which cannot be formed without many negroes of the King's plantation being accomplices therein: and if there are any, I take upon me, said I, to find them out, and arrest them, if necessary, without any disorder or tumult.

The Governor and the whole Court approved of my reasons: I went that very evening to the camp of the negroes, and from hut to hut, till I saw a light. In this hut I heard them talking together of their scheme. One of them was my first commander and my confidant, which surprised me greatly; his name was Samba.

I speedily retired for fear of being discovered; and in two days after, eight negroes, who were at the head of the conspiracy, were separately arrested, unknown to each other, and clapt in irons without the least tumult.

The day after, they were put to the torture of burning matches, which, though several times repeated, could not bring them to make any confession. In the mean time I learnt that Samba had in his own country been at the head of the revolt by which the French lost Fort Arguin; and when it was recovered again by M. Perier de Salvert, one of the principal articles of the peace was, that this negro should be condemned to slavery in America: that Samba, on his passage, had laid a scheme to murder the crew, in order to become master of the ship; but that being discovered, he was put in irons, in which he continued till he landed in Louisiana.

I drew up a memorial of all this; which was read before Samba by the Judge Criminal; who, threatening him again with torture, told him, he had ever been a seditious fellow: upon which Samba directly owned all the circumstances of the conspiracy; and the rest being confronted with him, confessed 
also: after which, the eight negroes were condemned to be broke alive on the wheel, and the woman to be hanged before their eyes; which was accordingly done, and prevented the conspiracy from taking effect.

\section{ChaPter XII.}

The War of the Natchez. Massacre of the French in 1729. Extirpation of the Natchez in 1730.

TN the beginning of the month of December 1729, we heard at New Orleans, with the most affecting grief, of the massacre of the French at the post of the Natchez, occasioned by the imprudent conduct of the Commandant. I shall trace that whole affair from its rise.

The Sieur de Chopart had been Commandant of the post of the Natchez, from which he was removed on account of some acts of injustice. M. Perier, Commandant General, but lately arrived, suffered himsef to be prepossessed in his favour, on his telling him, that he had commanded that post with applause: and thus he obtained the command from M. Perier, who was unacquainted with his character.

This new Commandant, on taking possession of his post, projected the forming one of the most eminent settlements of the whole colony. For this purpose he examined all the grounds unoccupied by the French, but could not find any thing that came up to the grandeur of his views. Nothing but the village of the White Apple, a square league at least in extent, could give him satisfaction; where he immediately resolved to settle. This ground was distant from the fort about two leagues. Conceited with the beauty of his project, the Commandant sent for the Sun of that village to come to the fort.

The Commandant, upon his arrival at the fort, told him, without further ceremony, that he must look out for another ground to build his village on, as he himself resolved, as soon as possible, to build on the village of the Apple; that he must directly clear the huts, and retire somewhere else. The better to cover his design, he gave out, that it was necessary for the 
French to settle on the banks of the rivulet, where stood the Great Village, and the abode of the Grand Sun. The Commandant, doubtless, supposed that he was speaking to a slave, whom we may command in a tone of absolute authority. But he knew not that the natives of Louisiana are such enemies to a state of slavery, that they prefer death itself thereto; above all, the Suns, accustomed to govern despotically, have still a greater aversion to it.

The Sun of the Apple thought, that if he was talked to in a reasonable manner, he might listen to him: in this he had been right, had he to deal with a reasonable person. He therefore made answer, that his ancestors had lived in that village for as many years as there were hairs in his double cue; and therefore it was good they should continue there still.

Scarce had the interpreter explained this answer to the Commandant, but he fell into a passion, and threatened the Sun, if he did not quit his village in a few days, he might repent it. The Sun replied, when the French came to ask us for lands to settle on, they told us there was land enough still unoccupied, which they might take; the same sun would enlighten them all, and all would walk in the same path. He wanted to proceed, farther in justification of what he alleged; but the Commandant, who was in a passion, told him, he was resolved to be obeyed, without any further reply. The Sun, without discovering any emotion or passion, withdrew; only saying, he was going to assemble the old men of his village, to hold a council on this affair.

He actually assembled them: and in this council it was resolved to represent to the Commandant, that the corn of all the people of their village was already shot a little out of the earth, and that all the hens were laying their eggs; that if they quitted their village at present, the chickens and corn would be lost both to the French and to themselves; as the French were not numerous enough to weed all the corn they had sown in their fields.

This resolution taken, they sent to propose it to the Commandant, who rejected it with a menace to chastise them if they did not obey in a very short time, which he prefixed. 
The Sun reported this answer to his council, who debated the question, which was knotty. But the policy of the old men was, that they should propose to the Commandant, to be allowed to stay in their village till harvest, and till they had time to dry their corn, and shake out the grain; on condition each hut of the village should pay him in so many moons (months,) which they agreed on, a basket of corn and a fowl; that this Commandant appeared to be a man highly self-interested; and that this proposition would be a means of gaining time, till they should take proper measures to withdraw themselves from the tyrrany of the French.

The Sun returned to the Commandant, and proposed to pay him the tribute I just mentioned, if he waited till the first colds, (winter;) and then the corn would be gathered in, and dry enough to shake out the grain; that thus they would not be exposed to lose their corn, and die of hunger: that the Commandant himself would find his account in it; and that as soon as any corn was shaken out, they should bring him some.

The avidity of the Commandant made him accept the proposition with joy, and blinded him with regard to the consequences of his tyrrany. He, however, pretended that he agreed to the offer out of favour, to do a pleasure to a nation so beloved, and who had ever been good friends of the French. The Sun appeared highly satisfied to have obtained a delay sufficient for taking the precautions necessary to the security of the nation; for he was by no means the dupe of the feigned benevolence of the Commandant.

The Sun, upon his return, caused the council to be assembled; told the old men, that the French Commandant had acquiesced in the offers which he had made him, and granted the term of time they demanded. He then laid before them, that it was necessary wisely to avail themselves of this time, in order to withdraw themselves from the proposed payment and tyrannic domination of the French, who grew dangerous in proportion as they multiplied. That the Natchez ought to remember the war made upon them, in violation of the peace concluded between them: that this war having been made upon their village alone, they ought to consider of the surest means: 
to take a just and bloody vengeance: that this enterprise being of the utmost consequence, it called for much secrecy, for solid measures, and for much policy: that thus it was proper to cajole the French Chief more than ever: that this affair required some days to reflect on, before they came to a resolution therein, and before it should be proposed to the Grand Sun and his council: that at present they had only to retire; and in a few days he would assemble them again, that they might then determine the part they were to act.

In five or six days he brought together the old men, who in that interval were consulting with each other: which was the reason that all the suffrages were unanimous in the same and only means of obtaining the end they proposed to themselves, which was the entire destruction of the French in this province.

The Sun, seeing them all assembled, said: "You have had time to reflect on the proposition I made you; and so I imagine you will soon set forth the best means how to get rid of your bad neighbours without hazard." The Sun having done speaking, the oldest rose up, saluted his Chief after his manner, and said to him:

"We have a long time been sensible that the neighbourhood of the French is a greater prejudice than benefit to us: we, who are old men, see this; the young see it not. The wares of the French yield pleasure to the youth; but in effect, to what purpose is all this, but to debauch the young women, and taint the blood of the nation, and make them vain and idle? The young men are in the same case; and the married must work themselves to death to maintain their families, and please their children. Before the French came amongst us, we were men, content with what we had, and that was sufficient: we walked with boldness every road, because we were then our own masters: but now we go groping, afraid of meeting thorns, we walk like slaves, which we shall soon be, since the French already treat us as if we were such. When they are sufficiently strong, they will no longer dissemble. For the least fault of our young people, they will tie them to a post, and whip them as they do their black slaves. Have they not 
already done so to one of our young men; and is not death preferable to slavery?"

Here he paused a while, and after taking breath, proceeded thus :

"What wait we for? Shall we suffer the French to multiply, till we are no longer in a condition to oppose their efforts? What will the other nations say of us, who pass for the most ingenious of all the Red-men? They will then say, we have less understanding than other people. Why then wait we any longer? Let us set ourselves at liberty, and show we are really men, who can be satisfied with what we have. From this very day let us begin to set about it, order our women to get provisions ready, without telling them the reason; go and carry the Pipe of Peace to all the nations of this country; make them sensible, that the French being stronger in our neighbourhood than elsewhere, make us, more than others, feel that they want to enslave us; and when become sufficiently strong, will in like manner treat all the nations of the country; that it is their interest to prevent so great a misfortune; and for this purpose they have only to join us, and cut off the French to a man, in one day and one hour; and the time to be that on which the term prefixed and obtained of the French Commandant, to carry him the contribution agreed on, is expired; the hour to be the quarter of the day (nine in the morning;) and then several warriors to go and carry him the corn, as the beginning of their several payments, also carry with them their arms, as if going out to hunt: and that to every Frenchman in a French house, there shall be two or three Natchez; to ask to borrow arms and ammunition for a general hunting-match, on account of a great feast, and to promise to bring them meat; the report of the firing at the Commandant's, to be the signal to fall at once upon, and kill the French: that then we shall be able to prevent those who may come from the old French village, (New Orleans) by the great water (Missisippi) ever to settle here."

He added, that after apprising the other nations of the necessity of taking that violent step, a bundle of rods, in number equal to that they should reserve for themselves, should be 
left with each nation, expressive of the number of days that were to precede that on which they were to strike the blow at one and the same time. And to avoid mistakes, and to be exact in pulling out a rod every day, and breaking and throwing it away, it was necessary to give this in charge to a person of prudence. Here he ceased and sat down: they all approved his counsel, and were to a man of his mind.

The project was in like manner approved of by the Sun of the Apple: the business was to bring over the Grand Sun, with the other petty Suns, to their opinion; because all the Princes being agreed as to that point, the nation would all to a man implicitly obey. They however took the precaution to forbid apprising the women thereof, not excepting the female Suns, (Princesses) or giving them the least suspicion of their designs against the French.

The Sun of the Apple was a man of good abilities; by which means he easily brought over the Grand Sun to favour his scheme, he being a young man of no experience in the world, and having no great correspondence with the French: he was the more easily gained over, as all the Suns were agreed, that the Sun of the Apple was a man of solidity and penetration; who having repaired to the Sovereign of nation, apprised him of the necessity of taking that step, as in time himself would be forced to quit his own village; also of the wisdom of the measures concerted, such as even ascertained success; and of the danger to which his youth was exposed with neighbours so enterprising; above all, with the present French Commandant, of whom the inhabitants, and even the soldiers complained: that as long as the Grand Sun, his father, and his uncle, the Stung Serpent, lived, the Commandant of the fort durst never undertake any thing to their detriment; because the Grand Chief of the French, who resides at their great village (New Orleans,) had a love for them: but that he, the Grand Sun, being unknown to the French, and but a youth, would be despised. In fine, that the only means to preserve his authority, was to rid himself of the French, by the method, and with the precautions projected by the old men. 
The result of this conversation was, that on the day following, when the Suns should in the morning come to salute the Grand Sun, he was to order them to repair to the Sun of the Apple, without taking notice of it to any one. This was accordingly executed, and the seducing abilities of the Sun of the Apple drew all the Suns into his scheme. In consequences of which they formed a council of Suns and aged Nobles, who all approved of the design: and then these aged Nobles were nominated heads of embassies to be sent to the several nations; had a guard of Warriors to accompany them, and on pain of death, were discharged from mentioning it to any one whatever. This resolution taken, they set out severally at the same time, unknown to the French.

Notwithstanding the profound secrecy observed by the Natchez, the council held by the Suns and aged Nobles gave the people uneasiness, unable as they were to penetrate into the matter. The female Suns (Princesses) had alone in this nation a right to demand why they were kept in the dark in this affair. The young Grand female Sun was a Princess scarce eighteen: and none but the Stung Arm, a woman of great wit, and no less sensible of it, could be offended that nothing was disclosed to her. In effect, she testified her displeasure at this reserve with respect to herself, to her son; who replied, that the several deputations were made, in order to renew their good intelligence with the other nations, to whom they had not of a long time sent an embassy, and who might imagine themselves slighted by such a neglect. This feigned excuse seemed to appease the Princess, but not quite to rid her of all her uneasiness; which, on the contrary, was heightened, when, on the return of the embassies, she saw the Suns assemble in secret council together with the deputies, to learn what reception they met with; whereas ordinarily they assembled in public.

At this the female Sun was filled with rage, which would have openly broke out, had not her prudence set bounds to it. Happy it was for the French, she imagined herself neglected: for I am persuaded the colony owes its preservation to the vexation of this woman rather than to any remains of affection 
she entertained for the French, as she was now far advanced in years, and her gallant dead some time.

In order to get to the bottom of the secret, she prevailed on her son to accompany her on a visit to a relation, that lay sick at the village of the Meal; and leading him the longest way about, and most retired, took occasion to reproach him with the secrecy he and the other Suns observed with regard to her, insisting with him on her right as a mother, and her privilege as a Princess: adding, that though all the world, and herself too, had told him he was the son of a Frenchman, yet her own blood was much dearer to her than that of strangers; that he needed not apprehend she would ever betray him to the French, against whom, she said, you are plotting.

Her son, stung with these reproaches, told her, it was unusual to reveal what the old men of the council had once resolved upon; alledging, he himself, as being Grand Sun, ought to set a good example in this respect: that the affair was concealed from the Princess his consort as well as from her; and that though he was the son of a Frenchman, this gave no mistrust of him to the other Suns. But seeing, says he, you have guessed the whole affair, I need not inform you farther; you know as much as I do myself, only hold your tongue.

She was in no pain, she replied, to know against whom he had taken his precautions: but as it was against the French, this was the very thing that made her apprehensive he had not taken his measures aright in order to surprise them; as they were a people of great penetration, though their Commandant had none: that they were brave, and could bring over by their presents, all the Warriors of the other nations; and had resources, which the Red-men were without.

Her son told her she had nothing to apprehend as to the measures taken: that all the nations had heard and approved their project, and promised to fall upon the French in their neighbourhood, on the same day with the Natchez: that the Chactaws took upon them to destroy all the French lower down and along the Missisippi, up as far as the Tonicas; to which last people, he said, we did not send, as they and the Oumas 
are too much wedded to the French; and that it was better to involve both these nations in the same general destruction with the French. He at last told her, the bundle of rods lay in the temple, on the flat timber.

The Stung Arm being informed of the whole design, pretended to approve of it, and leaving her son at ease, henceforward was only solicitous how she might defeat this barbarous design: the time was pressing, and the term prefixed for the execution was almost expired.

This woman, unable to bear to see the French cut off to a man in one day by the conspiracy of the natives, sought how to save the greatest part of them: for this purpose she bethought herself of acquainting some young women therewith. who loved the French, enjoining them never to tell from whom they had their information.

She herself desired a soldier she met, to go and tell the Commandant, that the Natchez had lost their senses, and to desire him to be upon his guard: that he need only make the smallest repairs possible on the fort, in presence of some of them, in order to shew his mistrust; when all their resolutions and bad designs would vanish and fall to the ground.

The soldier faithfully performed his commission: but the Commandant, far from giving credit to the information, or availing himself thereof; or diving into, and informing himself of the grounds of it, treated the soldier as a coward and a visionary, caused him to be clapt in irons, and said, he would never take any step towards repairing the fort, or putting himself on his guard, as the Natchez would then imagine he was a man of no resolution, and was struck with a mere panick.

The Stung Arm fearing a discovery, notwithstanding her utmost precaution, and the secrecy she enjoined, repaired to the temple, and pulled some rods out of the fatal bundle: her design was to hasten or forward the term prefixed, to the end that such Frenchmen as escaped the massacre, might apprize their countrymen, many of whom had informed the Commandant; who clapt seven of them in irons, treating them as cowards on that account. 
The female Sun, seeing the term approaching, and many of those punished, whom she had charged to acquaint the Governor, resolved to speak to the Under-Lieutenant; but to no better purpose, the Commandant paying no greater regard to him than to the common soldiers.

Notwithstanding all these informations, the Commandant went out the night before on a party of pleasure, with some other Frenchmen, to the grand village of the Natchez, without returning to the fort till break of day; where he was no sooner come, but he had pressing advice to be upon his guard.

The Commandant, still flustered with his last night's debauch, added imprudence to his neglect of these last advices; and ordered his interpreter instantly to repair to the grand village, and demand of the Grand Sun, whether he intended, at the head of his Warriors, to come and kill the French, and to bring him word directly. The Grand Sun, though but a young man, knew how to dissemble, and spoke in such a manner to the interpreter, as to give full satisfaction to the Commandant, who valued himself on his contempt of former advices; he then repaired to his house, situate below the fort.

The Natchez had too well taken their measures to be disappointed in the success thereof. The fatal moment was at last come. The Natchez set out on the Eve of St. Andrew, 1729, taking care to bring with them one of the lower sort, armed with a wooden hatchet, in order to knock down the Commandant*: they had so high a contempt for him, that no Warrior would deign to kill him. The houses of the French filled with enemies, the fort in like manner with the natives, who entered in at the gate and breaches, deprived the soldiers, without officers, or even a serjeant at their head, of the means of self defence. In the mean time the Grand Sun arrived, with some Warriors loaded with corn, in appearance as the first payment of the contribution; when several shot were fired. As this firing was the signal, several shot were heard at the same instant. Then at length the Commandant saw, but too late, his folly: he ran into his garden, whither he was pursued

* Others say he was shot: but neither account can be ascertained, as no Frenchman present escaped. 
and killed. This Massacre was executed every where at the same time. Of about seven hundred persons, but few escaped to carry the dreadful news to the capital; on receiving which the Governor and Council were sensibly affected, and orders were dispatched every where to put people on their guard.

The other Indians were displeased at the conduct of the Natchez, imagining they had forwarded the term agreed on, in order to make them ridiculous, and proposed to take vengeance the first opportunity, not knowing the true cause of the precipitation of the Natchez.

After they had cleared the fort, warehouse, and other houses, the Natchez set them all on fire, not leaving a single building standing.

The Yazous, who happened to be at that very time on an embassy to the Natchez, were prevailed on to destroy the post of the Yazous; which they failed not to effect some days after, making themselves masters of the fort, under colour of paying a visit, as usual, and knocking all the garrison on the head.

M. Perier, Governor of Louisiana, was then taking the proper steps to be avenged: he sent M. le Sueur to the Chactaws, to engage them on our side against the Natchez; in which he succeeded without any difficulty. The reason of their readiness to enter into this design was not then understood, it being unknown that they were concerned in the plot of the Natchez to destroy all the French, and that it was only to be avenged of the Natchez, who had taken the start of them, and not given them a sufficient share of the booty.

M. de Loubois, king's lieutenant, was nominated to be at the head of this expedition: he went up the river with a small army, and arrived at the Tonicas. The Chactaws at length in the month of February near the Natchez, to the number of fifteen or sixteen hundred men, with M. le Sueur at their head; whither M. de Loubois came the March following.

The army encamped near the ruins of the old French settlement; and after resting five days there, they marched to the enemy's fort, which was a league from thence. 
After opening the trenches and firing for several days upon the fort without any great effect, the French at last made their approach so near as to frighten the enemy, who sent to offer to release all the French women and children, on the condition of obtaining a lasting peace, and of being suffered to live peaceably on their ground, without being driven from thence, or molested for the future.

M. de Loubois assured them of peace on their own terms, if they also gave up the French, who were in the fort, and all the negroes they had taken belonging to the French; and if they agreed to destroy the fort by fire. The Grand Sun accepted these conditions, provided the French general should promise, he would neither enter the fort with the French, nor suffer their auxiliaries to enter; which was accepted by the general; who sent the allies to receive all the slaves.

The Natchez, highly pleased to have gained time, availed themselves of the following night, and went out of the fort, with their wives and children, loaded with their baggage and the French plunder, leaving nothing but the cannon and ball behind.

M. de Loubois was struck with amazement at this escape, and only thought of retreating to the landing-place, in order to build a fort there: but first it was necessary to recover the French out of the hands of the Chactaws, who insisted on a very high ransom. The matter was compromised by means of the grand chief of the Tonicas, who prevailed on them to accept what M. de Loubois was constrained to offer them, to satisfy their avarice; which they accordingly accepted, and gave up the French slaves, on promise of being paid as soon as possible: but they kept as security a young Frenchman and some negro slaves, whom they would never part with, till payment was made.

M. de Loubois gave orders to build a terrace-fort, far preferable to a stoccado; there he left M. du Crenet, with an hundred and twenty men in garrison, with cannon and ammunition; after which he went down the Missisippi to New Orleans. The Chactaws, Tonicas, and other allies, returned home. 
After the Natchez had abandoned the fort, it was demolished, and its piles, or stakes, burnt. As the Natchez dreaded both the vengeance of the French, and the insolence of the Chactaws, that made them take the resolution of escaping in the night.

A short time after, a considerable party of the Natchez carried the Pipe of Peace to the Grand Chief of the Tonicas, under pretence of concluding a peace with him and all the French. The Chief sent to M. Perier to know his pleasure: but the Natchez in the mean time assassinated the Tonicas, beginning with their Grand Chief; and few of them escaped this treachery.

M. Perier, Commandant General, zealous for the service, neglected no means, whereby to discover in what part the Natchez had taken refuge. And after many enquiries he was told, they had entirely quitted the east side of the Missisippi, doubtless to avoid the troublesome and dangerous visits of the Chactaws; and in order to be more concealed from the French, had retired to the West of the Missisippi, near the Silver Creek, about sixty leagues from the mouth of the Red River.

These advices were certain: but the Commandant General not thinking himself in a condition fit to attack them without succours, had applied for that purpose to the Court; and succours were accordingly sent him.

In the mean time the Company, who had been apprized of the misfortune at the Post of the Natchez, and the losses they had sustained by the war, gave up that Colony to the King, with the privileges annexed thereto. The Company at the same time ceded to the King all that belonged to them in that Colony, as fortresses, artillery, ammunition, warehouses, and plantations, with the negroes belonging thereto. In consequence of which, his Majesty sent one of his ships, commanded by M. de Forant, who brought with him M. de Salmont, Commissary-General of the Marine, and Inspector of Louisiana, in order to take possession of that Colony in the King's name.

I was continued in the inspection of this plantation, now become the King's in 1730, as before. 
M. Perier, who till then had been Commandant General of Louisiana for the West India Company, was now made Governor for the King; and had the satisfaction to see his brother arrive, in one of the King's ships, commanded by M. Perier de Salvert, with the succours he demanded, which were an hundred and fifty soldiers of the marine. This Officer had the title of Lieutenant General of the Colony conferred upon him.

The Messrs. Perier set out with their army in very favourable weather; and arrived at last, without obstruction, near to the retreat of the Natchez. To get to that place, they went up the Red river, then the Black River, and from thence up the Silver Creek, which communicates with a small Lake at no great distance from the fort, which the Natchez had built, in order to maintain their ground against the French.

The Natchez, struck with terror at the sight of a vigilant enemy, shut themselves up in their fort. Despair assumed the place of prudence, and they were at their wits end, on seeing the trenches gain ground on the fort: they equip themselves like warriors, and stain their bodies with different colours, in order to make their last efforts by a sally, which resembled a transport of rage more than the calmness of valour, to the terror, at first, of the soldiers.

The reception they met from our men, taught them, however, to keep themselves shut up in their fort; and though the trench was almost finished, our Generals were impatient to have the mortars put in a condition to play on the place. At last they are set in battery; when the third bomb happened to fall in the middle of the fort, the usual place of residence of the women and children, they set up a horrible screaming; and the men, seized with grief at the cries of their wives and children, made the signal to capitulate.

The Natchez, after demanding to capitulate, started difficulties, which occasioned messages to and fro till night, which they waited to avail themselves of, demanding till next day to settle the articles of capitulation. The night was granted them, but being narrowly watched on the side next the gate, they could not execute the same project of escape, as in the war 
with M. de Loubois. However, they attempted it, by taking advantage of the obscurity of the night, and of the apparent stillness of the French: but they were discovered in time, the greatest part being constrained to retire into the fort. Some of them only happened to escape, who joined those that were out a hunting, and all together retired to the Chicasaws. The rest surrendered at discretion, among whom was the Grand Sun, and the female Suns, with several warriors, many women, young people, and children.

The French army re-embarked, and carried the Natchez as slaves to New Orleans, where they were put in prison; but afterwards, to avoid an infection, the women and children were disposed of in the King's plantation, and elsewhere; among these women was the female Sun, called the Stung Arm, who then told me all she had done, in order to save the French.

Some time after, these slaves were embarked for St. Domingo, in order to root out that nation in the Colony; which was the only method of effecting it, as the few that escaped had not a tenth of the women necessary to recruit the nation. And thus that nation, the most conspicuous in the Colony, and most useful to the French, was destroyed.

\section{Chapter XIII.}

The War with the Chicasaws. The first Expedition by the river Mobile. The second by the Missisippi. The war with the Chactaws terminated by the prudence of $\mathrm{M}$. de Vaudreuil.

THE War with the Chicasaws was owing to their having received and adopted the Natchez: though in this respect they acted only according to an inviolable usage and sacred custom, established among all the nations of North America; that when a nation, weakened by war, retires for shelter to another. who are willing to adopt them, and is pursued thither by their enemies, this is in effect to declare war against the nation adopting.

But M. de Biainville, whether displeased with this act of hospitality, or losing sight of this unalterable law, constantly 
prevailing among those nations, sent word to the Chicasaws, to give up the Natchez. In answer to his demand they alledged, that the Natchez having demanded to be incorporated with them, were accordingly received and adopted; so as now to constitute but one nation, or people, under the name of Chicasaws, that of Natchez being entirely abolished. Besides, added they, had Biainville received our enemies, should we go to demand them? or, if we did, would they be given up?

Notwithstanding this answer, M. de Biainville made warlike preparations against the Chicasaws, sent off Captain le Blanc, with six armed boats under his command; one laden with gun-powder, the rest with goods, the whole allotted for the war against the Chicasaws; the Captain at the same time carrying orders to M. d'Artaguette, Commandant of the Post of the Illinois, to prepare to set out at the head of all the troops, inhabitants and Indians, he could march from the Illinois, in order to be at the Chicasaws the 10th of May following, as the Governor himself was to be there at the same time.

The Chicasaws, apprized of the warlike preparations of the French, resolved to guard the Missisippi, imagining they would be attacked on that side. In vain they attempted to surprise M. le Blanc's convoy, which got safe to the Arkansas, where the gun-powder was left, for reasons no one can surmise.

From thence he had no cross accident to the Illinois, at which place he delivered the orders the Governor had dispatched for M. d'Artaguette; who finding a boat laden with gun-powder, designed for his post, and for the service of the war intended against the Chicasaws, left at the Arkansas, sent off the same day a boat to fetch it up; which on its return was taken by a party of Chicasaws; who killed all but M. du Tiffenet, junior, and one Rosalie, whom they made slaves.

In the mean time, M. de Biainville went by sea to Fort Mobile, where the Grand Chief of the Chactaws waited for him, in consequence of his engaging to join his Warriours with ours, in order to make war upon the Chicasaws, in consideration of a certain quantity of goods, part to be paid down directly, the rest at a certain time prefixed. The Governor, 
after this, returned to New Orleans, there to wait the opening of the campaign.

M. de Biainville, on his return, made preparations against his own departure, and that of the army, consisting of regular troops, some inhabitants and free negroes, and some slaves, all which set out from New Orleans for Mobile; where, on the 10th of March, 1736, the army, together with the Chactaws, was assembled; and where they rested till the $2 d$ of April, when they began their march, those from New Orleans taking their route by the river Mobile, in thirty large boats and as many pettyaugres; the Indians by land, marching along the east bank of that river; and making but short marches, they arrived at Tombecbec only the 20th of April, where M. de Biainville caused a fort to be built: here he gave the Chactaws the rest of the goods due to them, and did not set out from thence till the 4th of May. All this time was taken up with a Council of War, held on four soldiers, French and Swiss, who had laid a scheme to kill the Commandant and garrison, to carry off $M$. $\mathrm{du}$ Tiffenet and Rosalie, who had happily made their escape from the Chicasaws, and taken refuge in the fort, and to put them again into the hands of the enemy, in order to be better received by them, and to assist, and shew them how to make a proper defence against the French, and from thence to go over to the English of Carolina.

From the 4th of May, on which the army set out from Tombecbec, they took twenty days to come to the landingplace. After landing, they built a very extensive inclosure of palisadoes, with a shed, as a cover for the goods and ammuninition, then the army passed the night. On the 25th powder and ball were given out to the soldiers, and inhabitants, the sick with some raw soldiers being left to guard this old sort of fort.

From this place to the fort of the Chicasaws are seven leagues: this day they marched five leagues and a half in two columns and in file, across the woods. On the wings marched the Chactaws, to the number of twelve hundred at least, commanded by their Grand Chief. In the evening they encamped in a meadow, surrounded with wood. 
On the 26th of May they marched to the enemy's fort, across thin woods; and with water up to the waist, passed over a rivulet, which traverses a small wood; on coming out of which, they entered a fine plain: in this plain stood the fort of the Chicasaws, with a village defended by it. This fort is situated on an eminence, with an easy ascent; around it stood several huts, and at a greater distance towards the bottom, other huts, which appeared to have been put in a state of defence: quite close to the fort ran a little brook, which watered a part of the plain.

The Chactaws no sooner espied the enemy's fort, than they rent the air with their death-cries, and instantly flew to the fort: but their ardour flagged at a carabin-shot from the place. The French marched in good order, and got beyond a small wood, which they left in their rear, within cannon-shot of the enemy's fort, where an English flag was seen flying. At the same time four Englishmen, coming from the huts, were seen to go up the ascent, and enter the fort, where their flag was set up.

Upon this, it was imagined, they would be summoned to quit the enemy's fort, and to surrender, as would in like manner the Chicasaws: but nothing of this was once proposed. The General gave orders to the Majors to form large detachments of each of their corps, in order to go and take the enemy's fort. These orders were in part executed: three large detachments were made; namely, one of grenadiers, one of soldiers, and another of militia, or train-bands; who, to the number of twelve hundred men, advanced with ardour towards the enemy's fort, crying out aloud several times, Vive le Roi, as if already masters of the place; which, doubtless, they imagined to carry sword in hand; for in the whole army there was not. a single iron tool to remove the earth, and form the attacks.

The rest of the army marched in battle-array, ten men deep; mounted the eminence whereon the fort stood, and being come there, set fire to some huts, with wild-fire thrown at the ends of darts; but the smoke stifled the army.

The regular troops marched in front, and the militia, or train-bands, in rear. According to rule these train-bands 
made a quarter turn to right and left, with intent to go and invest the place. But M. de Jusan, Aid-Major of the troops, stopt short their ardor, and sent them to their proper post, reserving for his own corps the glory of carrying the place, which continued to make a brisk defence. Biainville remained at the quarters of reserve; where he observed what would be the issue of the attack, than which none could be more disadvantageous.

Both the regulars and inhabitants, or train-bands, gave instances of the greatest valour: but what could they do, open and exposed as they were, against a fort, whose stakes or wooden posts were a fathom in compass, and their joinings again lined with other posts, almost as big? From this fort, which was well garrisoned, issued a shower of balls; which would have mowed down at least half the assailants, if directed by men who knew how to fire. The enemy were under cover from all the attacks of the French, and could have defended themselves by their loop-holes. Besides, they formed a gallery of flat pallisadoes quite round, covered with earth, which screened it from the effects of grenadoes. In this manner the troops lavished their ammunition against the wooden posts, or stakes, of the enemy's fort, without any other effect than having thirty-two men killed, and almost seventy wounded; which last were carried to the body of reserve; from whence the General, seeing the bad success of the attack, ordered to beat the retreat, and sent a large detachment to favour it. It was now five in the evening, and the attack had been begun at half an hour after one. The troops rejoined the body of the army, without being able to carry off their dead, which were left on the field of battle, exposed to the rage of the enemy.

After taking some refreshment, they directly fortified themselves, by felling trees, in order to pass the night secure from the insults of the enemy, by being carefully on their guard. Next day it was observed the enemy had availed themselves of that night to demolish some huts, where the French, during the attack, had put themselves under cover, in order from thence to batter the fort. 
On the 27th, the day after the attack, the army began its march, and lay at a league from the enemy. The day following, at a league from the landing-place, whither they arrived next day, the French embarked for Fort Mobile, and from thence for the Capital, from which each returned to his own home.

A little time after, a serjeant of the garrison of the Illinois arrived at New Orleans, who reported, that, in consequence of the General's orders, M. d'Artaguette had taken his measures so well, that on the 9th of May he arrived with his men near the Chicasaws, sent out scouts to discover the arrival of the French army; which he continued to do till the 20th: that the Indians in alliance hearing no accounts of the French, wanted either to return home, or to attack the Chicasaws; which last M. d'Artaguette resolved upon, on the 21st, with pretty good success at first, having forced the enemy to quit their village and fort: that he then attacked another village with the same success, but that pursuing the runaways, M. d'Artaguette had received two wounds, which the Indians finding, resolved to abandon that Commandant, with forty-six soldiers and two serjeants, who defended their Commandant all that day, but were at last obliged to surrender; that they were well used by the enemy, who understanding that the French were in their country, prevailed on M. d'Artaguette to write to the General: but that this deputation having had no success, and learning that the French were retired, and despairing of any ransom for their slaves, put them to death by a slow fire. The serjeant added, he had the happiness to fall into the hands of a good master, who favoured his escape to Mobile.

M. de Biainville, desirous to take vengeance of the Chicasaws, wrote to France for succours, which the Court sent, ordering also the Colony of Canada to send succours. In the mean time M. de Biainville sent off a large detachment for the river St. Francis, in order to build a fort there, called also St. Francis.

The squadron which brought the succours from France being arrived, they set out, by going up the Missisippi, for the fort that had been just built. This army consisted of Marines, 
of the troops of the Colony, of several Inhabitants, many Negroes, and some Indians, our allies; and being assembled in this place, took water again, and still proceeded up the Missisippi to a little river called Margot, near the Cliffs called Prud'homme, and there the whole army landed. They encamped on a fine plain, at the foot of a hill, about fifteen leagues from the enemy; fortified themselves by way of precaution, and built in the fort a house for the Commandant, some cazerns, and a warehouse for the goods. This fort was called Assumption, from the day on which they landed.

They had waggons and sledges made, and the roads cleared for transporting cannon, ammunition, and other necessaries for forming a regular siege. There and then it was the succours from Canada arrived, consisting of French, Iroquois, Hurons, Episingles, Algonquins, and other nations: and soon after arrived the new Commandant of the Illinois, with the garrison, inhabitants, and neighbouring Indians, all that he could bring together, with a great number of horses.

This formidable army, consisting of so many different nations, the greatest ever seen, and perhaps that ever will be seen, in those parts, remained in this camp without undertaking any thing, from the month of August 1739, to the March following. Provisions, which at first were in great plenty, came at last to be so scarce, that they were obliged to eat the horses which were to draw the artillery, ammunition, and provisions: afterwards sickness raged in the army. M. de Biainville, who hitherto had attempted nothing against the Chicasaws, resolved to have recourse to mild methods. He therefore detached, about the 15th of March, the company of Cadets, with their Captain, M. de Celoron, their Lieutenant, M. de St. Laurent, and the Indians, who came with them from Canada, against the Chicasaws, with orders to offer peace to them in his name, if they sued for it.

What the General had foreseen, failed not to happen. As soon as the Chicasaws saw the French, followed by the Indians of Canada, they doubted not in the least, but the rest of that numerous army would soon follow; and they no sooner saw them approach, but they made signals of peace, and came out 
of their fort in the most humble manner, exposing themselves to all the consequences that might ensue, in order to obtain peace. They solemnly protested that they actually were, and would continue to be inviolable friends of the French; that it was the English, who prevailed upon them to act in this manner; but that they had fallen out with them on this account, and at that very time had two of that nation, whom they made slaves; and that the French might go and see whether they spoke truth.

M. de St. Laurent asked to go, and accordingly went with a young slave: but he might have had reason to have repented it, had not the men been more prudent than the women, who demanded the head of the Frenchman: but the men, after consulting together, were resolved to save him, in order to obtair. peace of the French, on giving up the two Englishmen. The women risk scarce any thing near so much as the men; these last are either slain in battle, or put to death by their enemies; whereas the women at worst are but slaves; and they all perfectly well know, that the Indian women are far better off when slaves to the French, than if married at home. M. de St. Laurent, highly pleased with this discovery, promised them peace in the name of M. de Biainville, and of all the French: after these assurances, they went all in a body out of the fort, to present the Pipe to $M$. de Celoron, who accepted it, and repeated the same promise.

In a few days after, he set out with a great company of Chicasaws, deputed to carry the Pipe to the French General, and deliver up the two Englishmen. When they came before M. de Biainville, they fell prostrate at his feet, and made him the same protestations of fidelity and friendship, as they had already made to Mi. de Celoron; threw the blame on the English; said they were entirely fallen out with them, and had taken these two, and put them in his hands, as enemies. They protested, in the most solemn manner, they would for ever be friends of the French and of their friends, and enemies of their enemies; in fine, that they would make war on the English, if it was thought proper, in order to shew that they renounced them as traitors. 
Thus ended the war with the Chicasaws, about the beginning of April, 1740. M. de Biainville dismissed the auxiliaries, after making them presents; razed the Fort Assumption, thought to be no longer necessary, and embarked with his whole army; and in passing down, caused the Fort St. Francis to be demolished, as it was now become useless; and he repaired to the Capital, after an absence of more than ten months.

Some years after, we had disputes with a part of the Chactaws, who followed the interests of the Red-Shoe, a Prince of that nation, who, in the first expedition against the Chicasaws, had some disputes with the French. This Indian, more insolent than any one of his nation, took a pretext to break out, and commit several hostilities against the French. M. de Vaudreuil, then Governor of Louisiana, being apprised of this, and of the occasion thereof, strictly forbad the French to frequent that nation, and to truck with them any arms or ammunition, in order to put a stop to that disorder in a short time, and without drawing the sword.

M. de Vaudreuil, afer taking these precautions, sent to demand of the Grand Chief of the whole nation, whether, like the Red-Shoe, he was also displeased with the French. He made answer, he was their friend: but that the Red-Shoe was a young man, without understanding. Having returned this answer, they sent him a present: but he was greatly surprised to find neither arms, powder, nor ball in this present, at a time when they were friends as before. This manner of proceeding, joined to the prohibition made of trucking with them arms or ammunition, heightened their surprise, and put them on having an explication on this head with the Governor; who made answer, That neither arms nor ammunition would be trucked with them, as long as the Red-Shoe had no more understanding; that they would not fail, as being brethren, to share a good part of the ammunition and arms with the Warriors of the Red-Shoe. This answer put them on remonstrating to the Village that insulted us; told them, if they did not instantly make peace with the French, they would themselves make war upon them. This threatening declaration made them sue for peace with the French, who were not in a condition to main- 
tain a war against a nation so numerous. And thus the prudent policy of M. de Vaudreuil put a stop to this war, without either expence or the loss of a man.

\section{CHAPTER XIV.}

Reflections on what gives Occasions to Wars in Louisiana. The Means of avoiding Wars in that Province, as also the Manner of coming off with Advantage and little Expence in them.

THE experience I have had in the art of war, from some campaigns I made in a regiment of dragoons till the peace of 1713, my application to the study of the wars of the Greeks, Romans, and other ancient people, and the wars I have seen carried on with the Indians of Louisiana, during the time I resided in that Province, gave me occasion to make several reflections on what could give rise to a war with the Indians, on the means of avoiding such a war, and on such methods as may be employed, in order either to make or maintain a war to advantage against them, when constrained thereto.

In the space of sixteen years that I resided in Louisiana, I remarked, that the war, and even the bare disputes we have had with the Indians of this Colony, never had any other origin, but our too familiar intercourse with them.

In order to prove this, let us consider the evils produced by this familiarity. In the first place, it makes them gradually drop that respect, which they naturally entertain for our nation.

In the second place, the French traffickers, or traders, are generally young people without experience, who, in order to gain the good-will of these people, afford them lights, or instruction, prejudicial to our interest. These young merchants are not, it is true, sensible of these consequences: but again, these people never lose sight of what can be of any utility to them, and the detriment thence accruing is not less great, nor less real.

In the third place, this familiarity gives occasion to vices, whence dangerous distempers ensue, and corruption of blood, 
which is naturally highly pure in this colony. These persons, who frequently resort to the Indians, imagined themselves authorized to give a loose to their vices, from the practice of these last, which is to give young women to their guests upon their arrival; a practice that greatly injures their health, and proves a detriment to their merchandizing.

In the fourth place, this resorting to the Indians puts these last under a constraint, as being fond of solitude; and this constraint is still more heightened, if the French settlement is near them; which procures them too frequent visits, that give them so much more uneasiness, as they care not on any account that people should see or know any of their affairs. And what fatal examples have we not of the dangers the settlements which are too near the Indians incur. Let but the massacre of the French be recollected, and it will be evident that this proximity is extremely detrimental to the French.

In the fifth and last place, commerce, which is the principal allurement that draws us to this new world instead of flourishing, is, on the contrary, endangered by the too familiar resort to the Indians of North America. The proof of this is very simple.

All who resort to countries beyond sea, know by experience, that when there is but one ship in the harbour, the Captain sells his cargo at what price he pleases: and then we hear it said, such a ship gained two, three, and sometimes as high as four hundred per cent. Should another ship happen to arrive in that harbour, the profit abates at least one half; but should three arrive, or even four successively, the goods then. are, so to speak, thrown at the head of the buyer: so that in this case a merchant has often great difficulty to recover his very expenses of fitting out. I should therefore be led to believe, that it would be for the interest of commerce, if the Indians were left to come to fetch what merchandize they wanted, who having none but us in their neighbourhood, would come for it, without the French running any risk in their commerce, much less in their lives.

For this purpose, let us suppose a nation of Indians on the banks of some river or rivulet, which is always the case, as all 
men whatever have at all times occasion for water. This being supposed, I look out for a spot proper to build a small terrasfort on, with fraises or stakes, and pallisadoes. In this fort I would build two small places for lodgings, of no great height; one to lodge the officers, the other the soldiers: this fort to have an advanced work, a half-moon, or the like, according to the importance of the post. The passage to be through this advanced work to the fort, and no Indian allowed to enter on any pretence whatever; not even to receive the Pipe of Peace there, but only in the advanced work; the gate of the fort to be kept shut day and night against all but the French. At the gate of the advanced work a sentinel to be posted, and that gate to be opened and shut on each person appearing before it. By these precautions we might be sure never to be surprised, either by avowed enemies, or by treachery. In the advanced work a small building to be made for the merchants, who should come thither to traffick or truck with the neighbouring Indians; of which last only three or four to be admitted at a time, all to have the merchandize at the same price, and no one to be favoured above another. No soldier or inhabitant to go to the villages of the neighbouring Indians, under severe penalties. By this conduct disputes would be avoided, as they only arise from too great a familiarity with them. These forts to be never nearer the villages than five leagues, or more distant than seven or eight. The Indians would make nothing of such a jaunt; it would be only a walk for them, and their want of goods would easily draw them, and in a little time they would become habituated to it. The merchants to pay a salary to an interpreter, who might be some orphan, brought up very young among these people.

This fort, thus distant a short journey, might be built without obstruction, or giving any umbrage to the Indians: as they might be told it was built in order to be at hand to truck their furs, and at the same time to give them no manner of uneasiness. One advantage would be, besides that of commerce, which would be carried on there, that these forts would prevent the English from having any communication with the Indians. as these last would find a great facility for their truck, and in forts so near them, every thing they could want. 
The examples of the surprise of the forts of the Natchez, the Yazoux, and the Missouris, shew but too plainly the fatal consequences of negligence in the service, and of a misplaced condescension in favour of the soldiers, by suffering them to build huts near the fort, and to lie in them. None should be allowed to lie out of the fort, not even the Officers. The Commandant of the Natchez, and the other Officers, and even the Serjeants, were killed in their houses without the fort. I should not be against the soldiers planting little fields of tobacco, potatoes, and other plants, too low to conceal a man: on the contrary, these employments would incline them to become settlers; but I would never allow them houses out of the fort. By this means a fort becomes impregnable against the most numerous; because they never will attack, should they have ever so much cause, as long as they see people on their guard.

Should it be objected that these forts would cost a great deal: I answer, that though there was to be a fort for each nation, which is not the case, it would not cost near so much as from time to time it takes to support wars, which in this country are very expensive, on account of the long journeys, and of transporting all the implements of war, hitherto made use of. Besides, we have a great part of these forts already built, so that we only want the advanced works; and two new forts more would suffice to compleat this design, and prevent the fraudulent commerce of the English traders.

As to the manner of carrying on the war in Louisiana, as was hitherto done, it is very expensive, highly fatiguing, and the risk always great; because you must first transport the ammunition to the landing-place; from thence travel for many leagues; then drag the artillery along by main force, and carry the ammunition on men's shoulders, a thing that harasses and weakens the troops very much. Moreover, there is a great deal of risk in making war in this manner: you have the approaches of a fort to make, which cannot be done without loss of lives: and should you make a breach, how many brave men are lost, before you can force men who fight like desperadoes, because they prefer death to slavery. 
I say, should you make a breach; because in all the time I resided in this Province, I never saw nor heard that the cannon which were brought against the Indian forts, ever made a breach for a single man to pass: it is therefore quite useless to be at that expence, and to harass the troops to bring artillery, which can be of no manner of service.

That cannon can make no breach in Indian forts may appear strange: but not more strange than true; as will appear, if we consider that the wooden posts or stakes which surround these forts, are too big for a bullet of the size of those used in these wars, to cut them down, though it were even to hit their middle. If the bullet gives more towards the edge of the tree, it glides off, and strikes the next to it; should the ball hit exactly between two posts, it opens them, and meets the post of the lining, which stops it short: another ball may strike the same tree, at the other joining, then it closes the little aperture the other had made.

Were I to undertake such a war, I would bring only a few Indian allies; I could easily manage them; they would not stand me so much in presents, nor consume so much ammunition and provisions: a great saving this; and bringing no cannon with me, I should also save expences. I would have none but portable arms; and thus my troops would not be harassed. The country every where furnishes wherewithal to make moveable intrenchments and approaches, without opening the ground: and I would flatter myself to carry the fort in two days time. There I stop: the reader has no need of this detail, nor I to make it public.

\section{Chapter XV.}

Pensacola taken by Surprize by the French. Retaken by the Spaniards. Again retaken by the French, and demolished.

BEFORE I go any farther, I think it necessary to relate what happened with respect to the Fort of Pensacola in Virginia*. This fort belongs to the Spaniards, and serves for an

* The author must mean Carolina. 
Entrepot, or harbour for the Spanish galleons to put into, in their passage from La Vera Cruz to Europe.

Towards the beginning of the year 1719, the Commandant General having understood by the last ships which arrived, that war was declared between France and Spain, resolved to take the post of Pensacola from the Spaniards; which stands on the continent, about fifteen leagues from Isle Dauphine, is defended by a staccado-fort the entrance of the road: over against it stands a fortin, or small fort, on the west point of the Isle St. Rose; which, on that side, defends the entrance of the road: this fort has only a guard-house to defend it.

The Commandant General; persuaded it would be impossible to besiege the place in form, wanted to take it by surprise, confiding in the ardor of the French, and security of the Spaniards, who were as yet ignorant of our being at war with them in Europe. With that view he assembled the few troops he had, with several Canadian and French planters, newly arrived, who went as volunteers. M. de Chateauguier, the Commandant's brother, and King's Lieutenant, commanded under him; and next him, M. de Richebourg, Captain. After arming this body of men, and getting the necessary supplies of ammunition and provisions, he embarked with his small army, and by the favour of a prosperous wind, arrived in a short time at his place of destination. The French anchored near the Fortin, made their descent undiscovered, seized on the guard-house, and clapt the soldiers in irons; which was done in less than half an hour. Some French soldiers were ordered to put on the cloaths of the Spaniards, in order to facilitate the surprising the enemy. The thing succeeded to their wish. On the morrow at day-break, they perceived the boat which carried the detachment from Pensacola, in order to relieve the guard of the fortin; on which the Spanish march was caused to be beat up; and the French in disguise receiving them, and clapping them in irons, put on their cloaths; and stepping into the same boat, surprised the sentinel, the guard-house, and at last the garrison, to the very Governor himself, who was taken in bed; so that they all were made prisoners without any bloodshed. 
The Commandant General, apprehensive of the scarcity of provisions, shipped off the prisoners, escorted by some soldiers, commanded by M. de Richebourg, in order to land them at the Havanna: he left his brother at Pensacola, to command there, with a garrison of sixty men. As soon as the French vessel had anchored at the Havanna, M. de Richebourg went on shore, to acquaint the Spanish Governor with his commission; who received him with politeness, and as a testimony of his gratitude, made him and his officers prisoners, put the soldiers in irons and in prison, where they lay for some time, exposed to hunger and the insults of the Spaniards, which determined many of them to enter into the service of Spain, in order to escape the extreme misery under which they groaned.

Some of the French, newly enlisted in the Spanish troops, informed the Governor of the Havanna, that the French garrison left at Pensacola was very weak: he, in his turn, resolved to carry that fort by way of reprisal. For that purpose he caused a Spanish vessel, with that which the French had brought to the Havanna, to be armed. The Spanish vessel stationed itself behind the Isle St. Rose, and the French vessel came before the fort with French colours. The sentinel enquired, who commanded the vessel? They answered, M. de Richebourg. This vessel, after anchoring, took down her French, and hoisted Spanish colours, firing three guns: at which signal, agreed on by the Spaniards, the Spanish vesseI joined the first; then they summoned the French to surrender. M. de Chateauguiere rejected the proposition, fired upon the Spaniards, and they continued cannonading each other till night.

On the following day the cannonading was continued till noon, when the Spaniards ceased firing, in order to summon the Commandant anew to surrender the fort: he demanded four days, and was allowed two. During that time, he sent to ask succours of his brother, who was in no condition to send him any.

The term being expired, the attack was renewed, the Commandant bravely defending himself till night; which two thirds of the garrison availed themselves of, to abandon their Gov- 
ernor, who, having only twenty men left, saw himself unable to make any longer resistance, demanded to capitulate, and was allowed all the honours of war; but in going out of the place, he and all his men were made prisoners. This infraction of the capitulation was occasioned by the shame the Spaniards conceived, of being constrained to capitulate in this manner with twenty men only.

As soon as the Governor of the Havanna was apprised of the surrender of the fort, vainly imagining he had overthrown half his enemies at least, he caused great rejoicings to be made in the island, as if he had gained a decisive victory, or carried a citadel of importance. He also sent off several vessels to victual and refresh his warriors, who, according to him, must have been greatly fatigued in such an action as I have just described.

The new Governor of Pensacola caused the fortifications to be repaired and even augmented; sent afterwards the vessel, named the Great Devil, armed with six pieces of cannon, to take Dauphin Island, or at least to strike terror into it. The vessel St. Philip, which lay in the road, entered a gut or narrow place, and there mooring across, brought all her guns to bear on the enemy; and made the Great Devil sensible, that Saints resist all the efforts of Hell.

This ship, by her position, served for a citadel to the whole island, which had neither fortifications nor intrenchments, nor any other sort of defence, excepting a battery of cannon at the east point, with some inhabitants, who guarded the coast, and prevented a descent. The Great Devil, finding she made no progress, was constrained, by way of relaxation, to go and pillage on the continent the habitation of the Sieur Miragouine, which was abandoned. In the mean time arrived from Pensacola, a little devil, a pink, to the assistance of the Great Devil. As soon as they joined, they began afresh to cannonade the island, which made a vigorous defence.

In the time that these two vessels attempted in vain to take the island, a squadron of five ships came in sight, four of them with Spanish colours, and the least carrying French hoisted to 
the top of the staff, as if taken by the four others. In this the French were equally deceived with the Spaniards: the former, however, knew the small vessel, which was the pink, the Mary, commanded by the brave M. Iapy. The Spaniards, convinced by these appearances, that succours were sent them, deputed two officers in a shallop on board the commodore: but they were no sooner on board, than they were made prisoners.

They were in effect three French men of war, with two ships of the Company, commanded by M. Champmelin: : These ships brought upwards of eight hundred men, and thirty officers, as well superior as subaltern, all of them old and faithful servants of the King, in order to remain in Louisiana. The Spaniards, finding their error, fled to Pensacola, to carry the news of this succour being arrived for the French.

The squadron anchored before the island, hoisted French colours, and fired a salvo, which was answered by the place. The St. Philip was drawn out and made to join the squadron: a new embarkation of troops was made, and the Mary left before Isle Dauphine.

On September the 7th, finding the wind favourable, the squadron set sail for Pensacola: by the way, the troops that were to make the attack on the continent, were landed near Rio Perdido; after which the ships, preceded by a boat, which shewed the way, entered the harbour, and anchored, and laid their broad sides, in spite of several discharges of cannon from the fort, which is upon the Isle of St. Rose. The ships had no sooner laid their broad-sides, but the cannonade began on both sides. Our ships had two forts to batter, and seven sail of ships that lay in the harbour. But the great land fort fired only one gun on our army, in which the Spanish Governor, having observed upwards of three hundred Indians, commanded by M. de St. Denis, whose bravery was universally acknowledged, was struck with such a panick, from the fear of falling into their hands, that he struck, and surrendered the place.

The fight continued for about two hours longer: but the heavy metal of our Commodore making great execution, the Spaniards cried out several times on board their ships, to 
strike; but fear prevented their executing these orders: none but a French prisoner durst do it for them. They quitted their ships, leaving matches behind, which would have soon set them on fire. The French prisoners between decks, no longer hearing the least noise, surmised a flight, came on deck, discovered the stratagem of the Spaniards, removed the matches, and thus hindered the vessels from taking fire, acquainting the Commodore therewith. The little fort held out but an hour longer, after which it surrendered for want of gunpowder. The Commandant came himself to put his sword in the hands of $M$. Champmelin, who embraced him, returned him his sword, and told him, he knew how to distinguish between a brave officer, and one who was not. He made his own ship his place of confinement, whereas the Commandant of the great fort was made the laughing-stock of the French.

All the Spaniards on board the ships, and those of the two forts were made prisoners of war: but the French deserters, to the number of forty, were made to cast lots; half of them were hanged at the yard-arms, the rest condemned to be galleyslaves to the Company for ten years in the country.

M. Champmelin caused the two forts to be demolished, preserving only three or four houses, with a warehouse. These houses were to lodge the officer, and the few soldiers that were left there, and one to be a guard-house. The rest of the planters were transported to Isle Dauphine, and M. Champmelin set sail for France*.

The history of Pensacola is the more necessary, as it is so near our settlements, that the Spaniards hear our guns, when we give them notice by that signal of our design to come and trade with them.

* At the peace that soon succeeded between France and Spain, Pensacola was restored to the last. 



\section{THE \\ HIS T O R Y \\ OF \\ L O U IS I A N A}

BOOK II.

Of the Country, and its Products.

\section{Chapter I.}

Geographical Description of Louisiana. Its Climate

LOUISIANA is that part of North America, which is bounded on the south by the Gulf of Mexico; on the east by Carolina, an English colony, and by a part of Canada; on the west by New Mexico; and on the north, in part by Canada; in part it extends, without any assignable bounds, to the Terræ Incognitæ, adjoining to Hudson's Bay*. Its breadth is about two hundred leagues $\dagger$, extending between the Spanish and English settlements; its length undetermined, as being altogether unknown. However, the source of the Missisippi will afford us some light on this head.

The climate of Louisiana varies in proportion as it extends northward: all that can be said of it in general is, that its southern parts are not so scorching as those of Africa in the

\footnotetext{
* By the charter granted by Louis XIV. to M. Crozat, Louisiana extends only "from the edge of the sea as far as the Illinois," which is not above half the extent assigned by our author.

$\dagger$ According to the best maps and accounts extant, the distance from the Missisippi to the mountains of New Mexico is about nine hundred miles, and from the Missisippi to the Atlantic Ocean about six hundred; reckoning sixty miles to a degree, and in a straight line.
} 
same latitude; and that the northern parts are colder than the corresponding parts of Europe. New Orleans, which lies in lat. $30^{\circ}$, as do the more northerly coasts of Barbary and Egypt, enjoys the same temperature of climate as Languedoc. Two degrees higher-up, at the Natchez, where I resided for eight years, the climate is far more mild than at New Orleans, the country lying higher: and at the Illinois, which is between $45^{\circ}$ and $46^{\circ}$, the summer is in no respect hotter than at Rochelle; but we find the frosts harder, and a more plentiful fall of snow. This difference of climate from that of Africa and Europe, I ascribe to two causes: the first is, the number of woods, which, though scattered up and down, cover the face of this country: the second, the great number of rivers. The former prevent the sun from warming the earth; and the latter diffuse a great degree of humidity: not to mention the continuity of this country with those to the northward; from which it follows, that the winds blowing from that quarter are much colder than if they traversed the sea in their course. For it is well known that the air is never so hot, and never so cold at sea, as on land.

We ought not therefore to be surprised, if in the southern part of Louisiana, a north wind obliges people in summer to be warmer cloathed; or if in winter a south wind admits of a lighter dress; as naturally owing, at the one time to the dryness of the wind, at the other, to the proximity of the Equator.

Few days pass in Louisiana without seeing the sun. The rain pours down there in sudden heavy showers, which do not last long, but disappear in half an hour, perhaps. The dews are very plentiful, advantageously supplying the place of rain.

We may therefore well imagine that the air is perfectly good there; the blood is pure; the people are healthy; subject to few diseases in the vigour of life, and without decrepitude in old age, which they carry to a far greater length than in France. People live to a long and agreeable old age in Louisiana, if they are but sober and temperate.

This country is extremely well watered, but much more so in some places than in others. The Missisippi divides this 
colony from north to south into two parts almost equal. The first discoverers of this river by the way of Canada, called it Colbert, in honour of that great Minister. By some of the savages of the north it is called Meact-Chassipi, which literally denotes, The Ancient Father of Rivers, of which the French have, by corruption formed Missisippi. Other Indians, especially those lower down the river, call it Balbancha; and at last the French have given it the name of St. Louis.

Several travellers have in vain attempted to go up to its source; which, however, is well known, whatever some authors, misinformed, may alledge to the contrary. We here subjoin the accounts that may be most depended upon.

M. de Charleville, a Canadian, and a relation of $M$. de Biainville. Commandant General of this colony, told me, that at the time of the settlement of the French, curiosity alone had led him to go up this river to its sources; that for this end he fitted out a canoe, made of the bark of the birch-tree, in order to be more portable in case of need. And that having thus set out with two Canadians and two Indians, with goods, ammunition, and provisions, he went up the river three hundred leagues to the north, above the Illinois: that there he found the Fall, called St. Antony's. This fall is a flat-rock, which traverses the river, and gives it only between eight or ten feet fall. He caused his canoe and effects to be carried over that place; and that embarking afterwards above the fall, he continued going up the river an hundred leagues more to the north, where he met the Sioux, a people inhabiting that country, at some distance from the Missisippi; some say, on each side of it.

The Sioux, little accustomed to see Europeans, were surprized at seeing him, and asked whither he was going. He told them, up the Missisippi to its source. They answered, that the country whither he was going was very bad, and where he would have great difficulty to find game for subsistence; that it was a great way off, reckoned as far from the source to the fall, as from this last to the sea. According to this information, the Missisippi must measure from its source to its mouth between fifteen and sixteen hundred leagues, as they reckon eight hundred leagues from St. Antony's Fall to the sea. This 
conjecture is the more probable, as that far to the north, several rivers of a pretty long course fall into the Missisippi; and that even above St. Antony's Fall, we find in this river between thirty and thirty-five fathom water, and a breadth in proportion; which can never be from a source at no great distance off. I may add, that all the Indians, informed by those nearer the source, are of the same opinion.

Though M. de Charleville did not see the source of the Missisippi, he, however, learned, that a great many rivers empty their waters into it: that even above St. Antony's Fall, he saw rivers on each side of the Missisippi, having a course of upwards of an hundred leagues.

It is proper to observe, that in going down the river from St. Antony's Fall, the right hand is the west, the left the east. The first river we meet from the fall, and some leagues lower down, is the river St. Peter, which comes from the west: lower down to the east, is the river St. Croix, both of them tolerable large rivers. We meet several others still less, the names of which are of no consequence. Afterwards we meet with the river Moingona, which comes from the west, about two hundred and fifty leagues below the fall, and upwards of an hundred and fifty leagues in length. This river is somewhat brackish. From that river to the Illinois, several rivulets or brooks, both to the right and left, fall into the Missisippi. The river of the Illinois comes from the east, and takes its rise on the frontiers of Canada; its length is two hundred leagues.

The river Missouri comes from a source about eight hundred leagues distant; and running from north-west to southeast, discharges itself into the Missisippi, about four or five leagues below the river of the Illinois. This river receives several others, in particular the river of the Canzas, which runs above an hundred and fifty leagues. From the rivers of the Illinois and the Missouri to the sea are reckoned five hundred leagues, and three hundred to St. Antony's Fall: from the Missouri to the Wabache, or Ohio, an hundred leagues. By this last river is the passage from Louisiana to Canada. This voyage is performed from New Orleans by going up the Missisippi to the Wabache; which they go up in the same manner quite to 
the river of the Miamis; in which they proceed as far as the Carrying-place; from which there are two leagues to a little river which falls into Lake Eric. Here they change their vessels; they come in pettyaugres, and go down the river St. Laurence to Quebec in birch canoes. On the river St. Laurence are several carrying-places, on account of its many falls or cataracts.

Those who have performed this voyage, have told me they reckoned eighteen hundred leagues from New Orleans to Quebec*. Though the Wabache is considered in Louisiana, as the most considerable of the rivers which come from Canada, and which, uniting in one bed, form the river commonly called by that name, yet all the Canadian travellers assure me, that the river called Ohio, and which falls into the Wabache, comes a much longer way than this last; which should be a reason for giving it the name Ohio; but custom has prevailed in this respect†.

From the Wabache, and on the same side, to Manchac, we see but very few rivers, and those very small ones, which fall into the Missisippi, though there are nearly three hundred and fifty leagues from the Wabache to Manchact. This will, doubtless, appear something extraordinary to those unacquainted with the country.

The reason, that may be assigned for it, appears quite natural and striking. In all that part of Louisiana, which is to the east of the Missisippi, the lands are so high in the neighbourhood of the river, that in many places the rain-water runs off from the banks of the Missisippi, and discharges itself into rivers, which fall either directly into the sea, or into lakes. Another very probable reason is, that from the Wabache to the sea, no rain falls but in sudden gusts; which defect is compensated by the abundant dews, so that the plants lose nothing by that means. The Wabache has a course of three hundred

* It is not above nine hundred leagues.

† But not among the English; we call it the Ohio.

\# That is, from the mouth of the Ohio to the river Iberville, which other accounts make but two hundred and fifty leagues. 
leagues, and the Ohio has its source a hundred leagues still farther off.

In continuing to go down the Missisippi, from the Wabache to the river of the Arkansas, we observe but few rivers, and those pretty small. The most considerable is that of St. Francis, which is distant thirty and odd leagues from that of the Arkansas. It is on this river of St. Francis, that the hunters of New Orleans go every winter to make salt provisions, tallow, and bears oil, for the supply of the capital.

The river of the Arkansas, which is thirty-five leagues lower down, and two hundred leagues from New Orleans, is so denominated from the Indians of that name, who dwell on its banks, a little above its confluence with the Missisippi. It runs three hundred leagues, and its source is in the same latitude with Santa-Fé, in New Mexico, in the mountains of which it rises. It runs up a little to the north for a hundred leagues, by forming a flat elbow, or winding, and returns from thence to the south-east, quite to the Missisippi. It has a cataract, or fall, about the middle of its course. Some call it the White River, because in its course it receives a river of that name. The Great Cut-point is about forty leagues below the river of the Arkansas: this was a long circuit which the Missisippi formerly took, and which it has abridged, by making its way through this point of land.

Below this river, still going towards the sea, we observe scarce any thing but brooks or rivulets, except the river of the Yasous, sixty leagues lower down. This river runs but about fifty leagues, and will hardly admit of a boat for a great way: it has taken its name from the nation of the Yasous, and some others dwelling on its banks. Twenty-eight leagues below the river of the Yasous, is a great cliff of a reddish free-stone: over-against this cliff are the great and little whirlpools.

From this little river, we meet but with very small ones, till we come to the Red River, called at first the Marne, because nearly as big as that river, which falls into the Seine. The Nachitoches dwell on its banks, and it was distinguished by the name of that nation; but its common name, and which it still bears, is that of the Red River. It takes its rise in New Mex- 
ico, forms an elbow to the north, in the same manner as the river of the Arkansas, falls down afterwards towards the Missisippi, running south east. They generally allow it a course of two hundred leagues. At about ten leagues from its confluence it receives the Black River, or the river of the Wachitas, which takes its rise pretty near that of the Arkansas. This rivulet, or source, forms, as is said, a fork pretty near its rise, one arm of which falls into the river of the Arkansas; the largest forms the Black River. Twenty leagues below the Red River is the Little Cut-point, and a league below that point are the little cliffs.

From the Red River to the sea we observe nothing but some small brooks: but on the east side, twenty-five leagues above New Orleans, we find a channel, which is dry at low water. The inundations of the Missisippi formed this channel (which is called Manchac) below some high lands, which terminate near that place. It discharges itself into the lake Maurepas, and from thence into that of St. Louis, of which I gave an account before.

The channel runs east south-east: formerly there was a passage through it; but at present it is so choaked up with dead wood, that it begins to have no water* but at the place where it receives the river Amité, which is pretty large, and which runs seventy leagues in a very fine country.

A very small river falls into the lake Maurepas, to the east of Manchac. In proceeding eastward, we may pass from this lake into that of St. Louis, by a river formed by the waters of the Amité. In going to the north of this lake, we meet to the east the little river Tandgipao. From thence proceeding always east, we come to the river Quéfoncté, which is long and beautiful, and comes from the Chactaws. Proceeding in the same route, we meet the river Castin-Bayouc: we may afterwards quit the lake by the channel, which borders the same country,

* Manchac is almost dry for three quarters of the year: but during the inundation, the waters of the river have a vent through it into the lakes Ponchartrain and St. Louis. Dumont, II. 297.

This is the river Iberville, which is to be the boundary of the British dominions. 
and proceeding eastward we meet with Pearl River which falls into this channel.

Farther up the coast, which lies from west to east, we meet St. Louis's Bay, into which a little river of that name discharges itself: farther on, we meet the river of the PaskaOgoulas: and at length we arrive at the Bay of Mobile, which runs upwards of thirty leagues into the country, where it receives the river of the same name, which runs for about a hundred and fifty leagues from north to south. All the rivers I have just mentioned, and which fall not into the Missisippi, do in like manner run from north to south.

Description of the Lower Louisiana, and the Mouths of the Missisippi.

I Return to Manchac, where I quitted the Missisippi. At a little distance from Manchac we meet the river of the Plaqumines; it lies to the west, and is rather a creek than a river. Three or four leagues lower down is the Fork, which is a channel running to the west of the Missisippi, through which a part of the inundations of that river run off. These waters pass through several lakes, and from thence to the sea, by Ascension Bay. As to the other rivers to the west of this bay, their names are unknown.

The waters which fall into those lakes consist not only of such as pass through this channel, but also of those that come out of the Missisippi, when overflowing its banks on each side: for, of all the water which comes out of the Missisippi over its banks, not a drop ever returns into its bed; but this is only to be understood of the low lands, that is, between fifty and sixty leagues from the sea eastward, and upwards of a hundred leagues westward.

It will, doubtless, seem strange, that a river which overflows its banks, should never after recover its waters again, either in whole or in part; and this will appear so much the more singular, as every where else it happens otherwise in the like circumstances.

It appeared no less strange to myself; and I have on all occasions endeavoured to the utmost, to find out what could 
produce an effect, which really appeared to me very extraordinary, and, I imagine, not without success.

From Manchac down to the sea, it is probable, and even in some degree certain, that all the lands thereabouts are brought down and accumulated by means of the ooze which the Missisippi carries along with it in its annual inundations; which begin in the month of March, by the melting of the snow to the north, and last for about three months. Those oozy or muddy lands easily produce herbs and reeds; and when the Missisippi happens to overflow the following year, these herbs and reeds intercept a part of this ooze, so that those at a distance from the river cannot retain so large a quantity of it, since those that grow next the river have stopt the greatest part; and by a necessary consequence, the others farther off, and in proportion as they are distant from the Missisippi, can retain a much less quantity of the mud. In this manner the land rising higher along the river, in process of time the banks of the Missisippi became higher than the lands about it. In like manner also these neighbouring lakes on each side of the river are remains of the sea, which are not yet filled up. Other rivers have firm banks, formed by the lands of Nature, a land of the same nature with the continent, and always adhering thereto: these sorts of banks, instead of augmenting, do daily diminish, either by sinking, or tumbling down into the bed of the river. The banks of the Missisippi, on the contrary, increase, and cannot diminish in the low and accumulated lands; because the ooze, alone deposited on its banks, increase them; which, besides, is the reason that the Missisippi becomes narrower, in place of washing away the earth, and enlarging its bed, as all other known rivers do. If we consider these facts, therefore, we ought no longer to be surprised that the waters of the Missisippi, when once they have left their bed, can never return thither again.

In order to prove this augmentation of lands, I shall relate what happened near Orleans: one of the inhabitants caused a well to be sunk at a little distance from the Missisippi, in order to procure a clearer water. At twenty feet deep there was found a tree laid flat, three feet in diameter: the height of the earth was therefore augmented twenty feet since the fall or lodging of that tree, as well by the accumulated mud, as by the 
rotting of the leaves, which fall every winter, and which the Missisippi carries down in vast quantities. In effect, it sweeps down a great deal of mud, because it runs for twelve hundred leagues at least across a country which is nothing else but earth, which the depth of the river sufficiently proves. It carries down vast quantities of leaves, canes and trees, upon its waters, the breadth of which is always above half a league, and sometimes a league and a quarter. Its banks are covered with much wood, sometimes for the breadth of a league on each side, from its source to its mouth. There is nothing therefore more easy to be conceived, than that this river carries down with its waters a prodigious quantity of ooze, leaves, canes and trees, which it continually tears up by the roots, and that the sea throwing back again all these things, they should necessarily produce the lands in question, and which are sensibly increasing. At the entrance of the pass or channel to the south-east, there was built a small fort, still called Balise. This fort was built on a little island, without the mouth of the river. In 1734 it stood on the same spot, and I have been told that at present it is half a league within the river: the land therefore hath in twenty years gained this space on the sea. Let us now resume the sequel of the Geographical Description of Louisiana.

The coast is bounded to the west by St. Bernard's Bay, where M. de la Salle landed; into this bay a small river falls, and there are some others which discharge their waters between this bay and Ascension bay; the planters seldom frequent that coast. On the east the coast is bounded by Rio Perdido, which the French corruptedly call aux Perdrix; Rio Perdido signifying Lost River, aptly so called by the Spaniards, because it loses itself under ground, and afterwards appears again, and discharges itself into the sea, a little to the East of Mobile, on which the first French planters settled.

From the Fork down to the sea, there is no river; nor is it possible there should be any, after what I have related: on the contrary, we find at a small distance from the Fork, another channel to the east, called the Bayouc of le Sueur: it is full of a soft ooze or mud, and communicates with the lakes which lie to the east. 
On coming nearer to the sea, we meet, at about eigint leagues from the principal mouth of the Missisippi, the first Pass; and a league lower down, the Otter Pass. These two passes or channels are only for pettyaugres. From this place there is no land fit to tread on, it being all a quagmire down to the sea. There also we find a point, which parts the mouths of the Missisippi : that to the right is called the South-Pass, or Channel; the west point of which runs two leagues farther into the sea than the point of the South-east Pass, which is to the left of that of the South Pass. At first vessels entered by the South-east Pass, but before we go down to it, we find to the left the East-Pass, which is that by which ships enter at present.

At each of these three Passes or Channels there is a Bar, as in all other rivers: these bars are three quarters of a league broad, with only eight or nine feet water: but there is a channel through this bar, which being often subject to shift, the coasting pilot is obliged to be always sounding, in order to be sure of the pass: this channel is, at low water, between seventeen and eighteen feet deep*.

This description may suffice to shew that the falling in with the land from sea is bad; the land scarce appears two leagues off; which doubtless made the Spaniards call the Missisippi Rio Escondido, the Hid River. This river is generally muddy, owing to the waters of the Missouri; for before this junction the water of the Missisippi is very clear. I must not omit mentioning that no ship can either enter or continue in the river when the waters are high, on account of the prodigious numbers of trees, and vast quantities of dead wood, which it carries down, and which, together with the canes, leaves, mud, and sand, which the sea throws back upon the coast, are continually augmenting the land, and make it project into the Gulf of Mexico, like the bill of a bird.

I should be naturally led to divide Louisiana into the Higher and Lower, on account of the great difference between

* I shall make no mention of the islands, which are frequent in the Missisippi, as being, properly speaking, nothing but little isles, produced by some trees, though the soil be nothing but a sand bottom. 
the two principal parts of this vast country. The Higher I would call that part in which we find stone, which we first meet with between the river of the Natchez and that of the Yasous, between which is a cliff of a fine free stone; and I would terminate that part at Manchac, where the high lands end. I would extend the Lower Louisiana from thence down to the sea. The bottom of the lands on the hills is a red clay, and so compact, as might afford a solid foundation for any building whatever. This clay is covered by a light earth, which is almost black, and very fertile. The grass grows there knee deep; and in the bottoms, which separate these small eminences, it is higher than the tallest man. Towards the end of September both are successively set on fire; and in eight or ten days young grass shoots up half a foot high. One will easily judge, that in such pastures herds of all creatures fatten extraordinarily. The flat country is watery, and appears to have been formed by every thing that comes down to the sea. I shall add, that pretty near the Nachitoches, we find banks of muscleshells, such as those of which Cockle-Island is formed. The neighbouring nation affirms, that according to their old tradition, the sea formerly came up to this place. The women of this nation go and gather these shells, and make a powder of them, which they mix with the earth, of which they make their pottery, or earthen ware. However, I would not advise the use of these shells indifferently for this purpose, because they are naturally apt to crack in the fire: I have therefore reason to think, that those found at the Nachitoches have acquired their good quality only by the discharge of their salts, from continuing for so many ages out of the sea.

If we may give credit to the tradition of these people, and if we would reason on the facts I have advanced, we shall be naturally led to believe, and indeed every thing in this country shews it, that the Lower Louisiana is a country gained on the sea, whose bottom is a crystal sand, white as snow, fine as flour, and such as is found both to the east and west of the Missisippi; and we may expect, that in future ages the sea and river may form another land like that of the Lower Louisiana. The Fort Balise shews that a century is sufficient to extend Louisiana two leagues towards the sea. 
CHAPTER II.

The Author's Journey in Louisiana, from the Natchez to the River St. Francis, and the Country of the Chicasaws.

HVER since my arrival in Louisiana, I made it my business to get information in whatever was new therein, and to make discoveries of such things as might be serviceable to society. I therefore resolved to take a journey through the country. And after leaving my plantation to the care of my friends and neighbours, I prepared for a journey into the interior parts of the province, in order to learn the nature of the soil, its various productions, and to make discoveries not mentioned by others.

I wanted to travel both for my own instruction, and for the benefit of the publick: but at the same time I desired to be alone, without any of my own countrymen with me; who, as they neither have patience, nor are made for fatigue, would be ever teazing me to return again, and not readily take up either with the fare or accommodations, to be met with on such a journey. I therefore pitched upon ten Indians, who were indefatigable, robust, and tractable, and sufficiently skilled in hunting, a qualification necessary on such journeys. I explained to them my whole design; told them, we should avoid passing through any inhabited countries, and would take our journeys through such as were unknown and uninhabited; because I travelled in order to discover what no one before could inform me about. This explication pleased them; and on their part they promised, I should have no reason to be dissatisfied with them. But they objected, they were under apprehensions of losing themselves in countries they did not know. To remove these apprehensions, I shewed them a mariner's compass, which removed all their difficulties, after I had explained to them the manner of using it, in order to avoid losing our way.

We set out in the month of September, which is the best season of the year for beginning a journey in this country: in the first place, because, during the summer, the grass is too high for travelling; whereas in the month of September, the meadows, the grass of which is then dry, are set on fire, and 
the ground becomes smooth, and easy to walk on: and hence it is, that at this time, clouds of smoke are seen for several days together to extend over a long track of country; sometimes to the extent of between twenty and thirty leagues in length, by two or three leagues in breadth, more or less, according as the wind sets, and is higher or lower. In the second place, this season is the most commodious for travelling over those countries; because, by means of the rain, which ordinarily falls after the grass is burnt, the game spread themselves all over the meadows, and delight to feed on the new grass; which is the reason why travellers more easily find provisions at this time than at any other. What besides facilitates these excursions in Autumn, or in the beginning of Winter, is, that all works in the fields are then at an end, or at least the hurry of them is over.

For the first days of our journey the game was pretty rare, because they shun the neighbourhood of men; if you except the deer, which are spread all over the country, their nature being to roam indifferently up and down; so that at first we were obliged to put up with this fare. We often met with flights of partridges, which the natives cannot kill, because they cannot shoot flying; I killed some for a change. The second day I had a turkey-hen brought to regale me. The discoverer, who killed it, told me, there were a great many in the same place, but that he could do nothing without a dog. I have often heard of a turkey-chace, but never had an opportunity of being at one: I went with him and took my dog along with me. On coming to the spot, we soon descried the hens, which ran off with such speed, that the swiftest Indian would lose his labour in attempting to outrun them. My dog soon came up with them, which made them take to their wings, and perch on the next trees; as long as they are not pursued in this manner, they only run, and are soon out of sight. I came near their place of retreat, killed the largest, a second, and my discoverer a third. We might have killed the whole flock; for, while they see any men, they never quit the tree they have once perched on. Shooting scares them not, as they only look at the bird that drops, and set up a timorous cry, as he falls. 
Before I proceed, it is proper to say a word concerning my discoverers, or scouts. I had always three of them out, one a-head, and one on each hand of me; commonly distant a league from me, and as much from each other. Their condition of scouts prevented not their carrying each his bed, and provisions for thirty-six hours upon occasion. Though those near my own person were more loaded, I however sent them out, sometimes one, sometimes another, either to a neighbouring mountain or valley: so that I had three or four at least, both on my right and left, who went out to make discoveries a small distance off. I did thus, in order to have nothing to reproach myself with, in point of vigilance, since I had begun to take the trouble of making discoveries.

The next business was, to make ourselves mutually understood, notwithstanding our distance: we agreed, therefore, on certain signals, which are absolutely necessary on such occasions. Every day, at nine in the morning, at noon, and at three in the afternoon, we made a smoke. This signal was the hour marked for making a short halt, in order to know, whether the scouts followed each other, and whether they were nearly at the distance agreed on. These smokes were made at the hours I mentioned, which are the divisions of the day according to the Indians. They divide their day into four equal parts; the first contains the half of the morning; the second is at noon; the third comprizes the half of the afternoon; and the fourth, the other half of the afternoon to the evening. It was according to this usage our signals were mutually made, by which we regulated our course, and places of rendezvous.

We marched for some days without finding any thing which could either engage my attention, or satisfy my curiosity. True it is, this was sufficiently made up in another respect; as we travelled over a charming country, which might justly furnish our painters of the finest imagination with genuine notions of landskips. Mine, I own, was highly delighted with the sight of fine plains, diversified with very extensive and highly delightful meadows. The plains were intermixed with thickets, planted by the hand of Nature herself; and interspersed with hills, running off in gentle declivities, and with 
valleys, thick set, and adorned with woods, which serve for a retreat to the most timorous animals, as the thickets screen the buffaloes from the abundant dews of the country.

I longed much to kill a buffalo with my own hand; I therefore told my people my intention to kill one of the first herd we should meet; nor did a day pass, in which we did not see several herds; the least of which exceeded a hundred and thirty or a hundred and fifty in number.

Next morning we espied a herd of upwards of two hundred. The wind stood as I could have wished, being in our faces, and blowing from the herd; which is a great advantage in this chace; because when the wind blows from you towards the buffaloes, they come to scent you, and run away, before you can come within gun-shot of them; whereas, when the wind blows from them on the hunters, they do not fly till they can distinguish you by sight; and then, what greatly favours your coming very near to them is, that the curled hair, which falls down between their horns upon their eyes, is so bushy, as greatly to confuse their sight. In this manner I came within full gun-shot of them, pitched upon one of the fattest, shot him at the extremity of the shoulder, and brought him down stonedead. The natives, who stood looking on, were ready to fire, had I happened to wound him but slightly; for in that case, these animals are apt to turn upon the hunter, who thus wounds them.

Upon seeing the buffalo drop down dead, and the rest taking to flight, the natives told me, with a smile: "You kill the males, do you intend to make tallow?" I answered, I did it on purpose, to shew them the manner of making him good meat, though a male. I caused his belly to be opened quite warm, the entrails to be taken out directly, the bunch, tongue, and chines to be cut out; one of the chines to be laid on the coals, of which I made them all taste; and they all agreed the meat was juicy, and of an exquisite flavour.

I then took occasion to remonstrate to them, that if, instead of killing the cows, as was always their custom, they killed the bulls, the difference in point of profit would be very con- 
siderable: as, for instance, a good commerce with the French in tallow, with which the bulls abound; bull's flesh is far more delicate and tender than cow's; a third advantage is, the selling of the skins at a higher rate, as being much better; in fine, this kind of game, so advantageous to the country, would thereby escape being quite destroyed; whereas, by killing the cows, the breed of these animals is greatly impaired.

I made a soup, that was of an exquisite flavour, but somewhat fat, of the broth boiled from the marrow-bones of this buffalo, the rest of the broth serving to make maiz-gruel, called Sagamity, which to my taste surpassed the best dish in France: the bunch on the back would have graced the table of a prince.

In the route I held, I kept more on the sides of the hills than on the plains. Above some of these sides, or declivities, I found, in some places, little eminences, which lay peeled, or bare, and disclosed a firm and compact clay, or pure matrix, and of the species of that of Lapis Calaminaris. The intelligent in Mineralogy understand what I would be at. The little grass, which grows there, was observed to droop, as also three or four misshapen trees, no bigger than one's leg; one of which I caused to be cut down; when, to my astonishment, I saw it was upwards of sixty years standing. The neighbouring country was fertile, in proportion to its distance from this spot. Near that place we saw game of every kind, and in plenty, and never towards the summit.

We crossed the Missisippi several times upon Cajeux (rafts, or floats, made of several bundles of canes, laid across each other; a kind of extemporaneous pontoon,) in order to take a view of mountains which had raised my curiosity. I observed, that both sides of the river had their several advantages; but that the West side is better watered; appeared also to be more fruitful both in minerals, and in what relates to agriculture; for which last it seems much more adapted than the East side.

Notwithstanding our precaution to make signals, one of my scouts happened one day to stray, because the weather was 
foggy; so that he did not return at night to our hut; at which I was very uneasy, and could not sleep; as he was not returned, though the signals of call had been repeated till night closed. About nine the next morning he cast up, telling us he had been in pursuit of a drove of deer, which were led by one that was altogether white: but that not being able to come up with them, he picked up, on the side of a hill, some small sharp stones, of which he brought a sample.

These stones I received with pleasure, because I had not yet seen any in all this country, only a hard red free-stone in a cliff on the Missisippi. After carefully examining those which my discoverer brought me, I found they were a gypsum. I took home some pieces, and on my return examined them more attentively; found them to be very clear, transparent, and friable; when calcined, they turned extremely white, and with them I made some factitious marble. This gave me hopes that this country, producing Plaster of Paris, might, besides, have stones for building.

I wanted to see the spot myself: we set out about noon, and travelled for about three leagues before we came to it. I examined the spot, which to me appeared to be a large quarry of Plaster.

As to the white deer above mentioned, I learned from the Indians, that some such were to be met with, though but rarely. and that only in countries not frequented by the hunters.

The wind being set in for rain, we resolved to put ourselves under shelter. The place where the bad weather overtook us was very fit to set up at. On going out to hunt, we discovered at five hundred paces off, in the defile, or narrow pass, a brook of a very clear water, a very commodious watering-place for the buffaloes, which were in great numbers all around us.

My companions soon raised a cabin, well-secured to the North. As we resolved to continue there for eight days at, least, they made it so close as to keep out the cold: in the night, I felt nothing of the severity of the North wind, though I lay but lightly covered. My bed consisted of a bear's skin, and two robes or coats of buffalo; the bear skin, with the flesh side 
undermost, being laid on leaves, and the pile uppermost by way of straw-bed; one of the buffalo coats folded double by way of feather-bed; one half of the other under me served for a matrass, and the other over me for a coverlet: three canes, or boughs, bent to a semicircle, one at the head, another in the middle, and a third at the feet, supported a cloth which formed my tester and curtains, and secured me from the injuries of the air, and the stings of gnats and moskitto's. My Indians had their ordinary hunting and travelling beds, which consist of a deer skin and a buffalo coat, which they always carry with them, when they expect to lie out of their villages. We rested nine days, and regaled ourselves with choice buffalo, turkey, partridge, pheasants, \&c.

The discovery I had made of the plaster, put me to look out, during our stay, in all the places round about, for many leagues. I was at last tired of beating about such fine plains, without discovering the least thing, and I had resolved to go forward to the North when at the noon-signal the scout a-head waited to shew me a shining and sharp stone, of the length and size of one's thumb, and as square as a joiner could have made a piece of wood of the same bigness. I imagined it might be rockcrystal; to be assured thereof, I took a large musquet flint in my left hand, presenting its head, or thick end, on which I struck with one of the edges of the crystal, and drew much more fire than with the finest steel: and notwithstanding the many strokes I gave, the piece of crystal was not in the least scratched or streaked.

I examined these stones, and found pieces of different magnitudes, some square, others with six faces, even and smooth like mirrors, highly transparent, without any veins or spots. Some of these pieces jutted out of the earth, like ends of beams, two feet and upwards in length; others in considerable numbers, from seven to nine inches; above all, those with six panes or faces. There was a great number of a middling and smaller sort: my people wanted to carry some with them; but I dissuaded them. My reason was, I apprehended some Frenchman might by presents prevail on them to discover the place. 
For my part, I carefully observed the latitude, and followed, on setting out, a particular point of the compass, to come to a river which I knew. I took that route, under pretense of going to a certain nation to procure dry provisions, which we were in want of, and which are of great help on a journey.

We arrived, after seven days march, at that nation, by whom we were well received. My hunters brought in daily many duck and teal. I agreed with the natives of the place for a large pettyaugre of black walnut, to go down the river, and afterwards to go up the Missisippi.

I had a strong inclination to go up still higher north, in order to discover mines. We embarked, and the eleventh day of our passage I caused the pettyaugre to be unladen of every thing, and concealed in the water, which was then low. I loaded seven men with the things we had.

Matters thus ordered, we set out according to the intention I had to go to the northward. I observed every day, with new pleasure, the more we advanced to that quarter, the more beautiful and fertile the country was, abounding in game of every kind: the herds of deer are numerous; at every turn we meet with them; and not a day passed without seeing herds of buffaloes, sometimes five or six, of upwards of an hundred in a drove.

In such journeys as these we always take up our night's lodging near wood and water, where we put up in good time: then at sun-set, when every thing in nature is hushed, we were charmed with the enchanting warbling of different birds; so that one would be inclined to say, they reserved this favourable moment for the melody and harmony of their song, to celebrate undisturbed and at their ease, the benefits of the Creator. On the other hand, we are disturbed in the night, by the hideous noise of the numberless water-fowls that are to be seen on the Missisippi, and every river or lake near it, such as cranes, flamingo's, wild geese, herons, saw-bills, ducks, \&c.

As we proceeded further north, we began to see flocks of swans roam through the air, mount out of sight, and proclaim 
their passage by their piercing shrill cries. We for some days followed the course of a river, at the head of which we found, in a very retired place, a beaver-dam.

We set up onr hut within reach of this retreat, or village of beavers, but at such a distance, as that they could not observe our fire. I put my people on their guard against making any noise, or firing their pieces, for fear of scaring those animals; and thought it even necessary to forbid them to cut any wood, the better to conceal ourselves.

After taking all these precautions, we rose and were on: foot against the time of moonshine, posted ourselves in a place: as distant from the huts of the beavers, as from the causey or bank, which dammed up the waters of the place where they were. I took my fusil and pouch, according to my custom of never travelling without them. But each Indian was only to take with him a little hatchet, which all travellers in this country carry with them. I took the oldest of my retinue, after having pointed out to the others the place of ambush, and the manner in which the branches of trees we had cut were to be: set to cover us. I then went towards the middle of the dam, with my old man, who had his hatchet, and ordered him softly to make a gutter or trench, a foot wide, which he began on the outside of the causey or dam, crossing it quite to the water. This he did by removing the earth with his hands. As soon as the gutter was finished, and the water ran into it, we speedily, and without any noise, retired to our place of ambush, in order to observe the behaviour of the beavers in repairing this breach.

A little after we were got behind our screen of boughs, we heard the water of the gutter begin to make a noise: and a moment after, a beaver came out of his hut and plunged into the water. We could only know this by the noise, but we saw him at once upon the bank or dam, and distinctly perceived that he took a survey of the gutter, after which he instantly gave with all his force four blows with his tail; and had scarce struck the fourth, but all the beavers threw themselves pellmell into the water, and came upon the dam: when they were all come thither, one of them muttered and mumbled to the 
rest (who all stood very attentive) I know not what orders, but which they doubtless understood well, because they instantly departed, and went out on the banks of the pond, one party one way; another, another way. Those next us were between us and the dam, and we at the proper distance not to be seen, and to observe them. Some of them made mortar, others carried it on their tails, which served for sledges. I observed they put themselves two and two, side by side, the one with his head to the other's tail, and thus mutually loaded each other, and trailed the mortar, which was pretty stiff, quite to the dam, where others remained to take it, put it into the gutter, and rammed it with blows of their tails.

The noise which the water made before by it fall, soon ceased, and the breach was closed in a short time: upon which one of the beavers struck two great blows with his tail, and instantly they all took to the water without any noise, and disappeared. We retired, in order to take a little rest in our hut, where we remained till day; but as soon as it appeared, I longed much to satisfy my curiosity about these creatures.

My people together made a pretty large and deep breach, in order to view the construction of the dam, which I shall describe presently: we then made noise enough without further ceremony. This noise, and the water, which the beavers observed soon to lower, gave them much uneasiness; so that I saw one of them at different times come pretty near to us, in order to examine what passed.

As I apprehended that when the water was run off they would all take flight to the woods, we quitted the breach, and went to conceal ourselves all round the pond, in order to kill only one, the more narrowly to examine it; especially as these beavers were of the grey kind, which are not so common as the brown.

One of the beavers ventured to go upon the breach, after having several times approached it, and returned again like a spy. I lay in ambush in the bottom, at the end of the dam: I saw him return; he surveyed the breach, then struck four blows, which saved his life, for I then aimed at him. But these 
four blows, so well struck, made me judge it was the signal of call for all the rest, just as the night before. This also made me think he might be the overseer of the works, and I did not choose to deprive the republic of beavers of a member who appeared so necessary to it. I therefore waited till others should appear: a little after, one came and passed close by me, in order to go to work; I made no scruple to lay him at his full length, on the persuasion he might only be a common labourer. My shot made them all return to their cabins, with greater speed than a hundred blows of the tail of their Overseer could have done. As soon as I had killed this beaver, I called my companions; and finding the water did not run off quick enough, I caused the breach to be widened, and I examined the dead.

I observed these beavers to be a third less than the brown or common sort, but their make the same; having the same head, same sharp teeth, same beards, legs as short, paws equally furnished with claws, and with membranes or webs, and in all respects made like the others. The only difference is, that they are of an ash-gray, and that the long pile, which passes over the soft wool, is silvered, or whitish.

During this examination, I caused my people to cut boughs, canes, and reeds, to be thrown in towards the end of the pond, in order to pass over the little mud which was in that place; and at the same time I caused some shot to be fired on the cabins that lay nearest us. The report of the guns, and the rattling of the shot on the roofs of the cabins, made them all fly into the woods with the greatest precipitation imaginable. We came at length to a cabin, in which there were not six inches of water. I caused to undo the roof without breaking any thing, during which I saw the piece of aspin-tree, which was laid under the cabin for their provisions.

I observed fifteen pieces of wood, with their bark in part gnawed. The cabin also had fifteen cells round the hole in the middle, at which they went out; which made me think each had his own cell.

I am now to give a sketch of the architecture of these amphibious animals, and an account of their villages; it is thus 


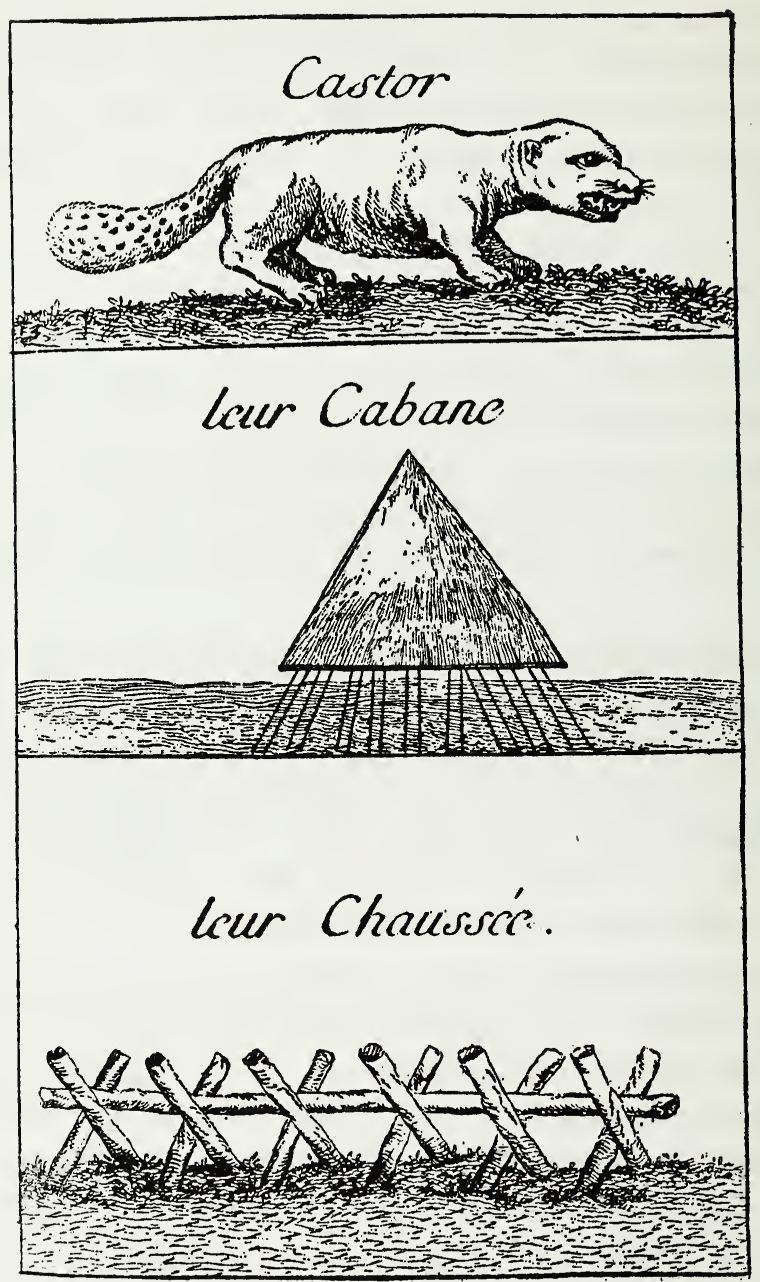

TOP: Beaver-MIDDLE: Beaver lodge Воттом: Beaver dam

I call the place of their abode, after the Canadians and the Indians, with whom I agree; and allow, these animals deserve so much the more to be distinguished from others, as I find their instinct far superior to that of other animals. I shall not. carry the parallel any farther, it might become offensive.

The cabins of the beavers are round, having about ten or twelve feet in diameter, according to the number, more or 
less, of fixed inhabitants. I mean, that this diameter is to be taken on the flooring at about a foot above the water, when it is even with the dam: but as the upper part runs to a point, the under is much larger than the flooring, which we may represent to ourselves, by supposing all the upright posts to resemble the legs of a great A, whose middle stroke is the flooring. These posts are picked out, and we might say, well proportioned, seeing, at the height this flooring is to be laid at, there is a hook for bearing bars, which by that means form the circumference of the flooring. The bars again bear traverses, or cross pieces of timber, which are the joists; canes and grass complete this flooring, which has a hole in the middle to go out at, when they please, and into this all the cells open.

The dam is formed of timbers, in the shape of St. Andrew's cross, or of a great X, laid close together, and kept firm by timbers laid lengthwise, which are continued from one end of the dam to the other, and placed on the St. Andrew's crosses: the whole is filled with earth, clapped close by great blows of their tails. The inside of the dam, next the water, is almost perpendicular; but on the outside it has a great slope, that grass coming to grow thereon, may prevent the water that passes there, to carry away the earth.

I saw them neither cut nor convey the timbers along, but it is to be presumed their manner is the same as that of other Beavers, who never cut but a soft wood; for which purpose they use their fore-teeth, which are extremely sharp. These timbers they push and roll before them on the land, as they do on the water, till they come to the place where they want to lay them. I observed these grey Beavers to be more chilly, or sensible of cold, than the other species: and it is doubtless for this reason they draw nearer to the south.

We set out from this place to come to a high ground, whick: seemed to be continued to a great distance. We came the same evening to the foot of it, but the day was too far advanced to ascend it. The day following we went to its top, found it a flat, except some small eminences at intervals. There appeared to be very little wood on it, still less water, and least of all stone; though probably there may be some in its bowels, hav- 
ing observed some stones in a part where the earth was tumbled down.

We accurately examined all this rising ground, without discovering any thing; and though that day we travelled upwards of five leagues, yet we were not three leagues distant from the hut we set out from in the morning. This high ground would have been a very commodious situation for a fine palace; as from its edges is a very distant prospect.

Next day, after a ramble of about two leagues and a half, I had the signal of call to my right. I instantly flew thither; and when I came, the scout shewed me a stump sticking out of the earth knee high, and nine inches in diameter. The Indian took it at a distance for the stump of a tree, and was surprised to find wood cut in a country which appeared to have been never frequented: but when he came near enough to form a judgement about it, he saw from the figure, that it was a very different thing: and this was the reason he made the signal of call.

I was highly pleased at this discovery, which was that of a lead-ore. I had also the satisfaction to find my perseverance recompensed; but in particular I was ravished with admiration, on seeing this wonderful production, and the power of the soil of this province, constraining, as it were, the minerals to disclose themselves. I continued to search all around, and I discovered ore in several places. We returned to lodge at our last hut, on account of the convenience of water, which was too scarce on this high ground.

We set out from thence, in order to come nearer to the Missisippi: through every place we passed, nothing but herds of buffaloes, elk, deer, and other animals of every kind, were to be seen; especially near rivers and brooks. Bears, on the other hand, keep in the thick woods, where they find their proper food.

After a march of five days I espied a mountain to my right, which seemed so high as to excite my curiosity. Next morning I directed thither my course, where we arrived about three in the afternoon. We stopped at the foot of the mountain, where we found a fine spring issuing out of the rock. 
The day following we went up to its top, where it is stony. Though there is earth enough for plants, yet they are so thin sown, that hardly two hundred could be found on an acre of ground. Trees are also very rare on that spot, and these poor, meagre, and cancerous. The stones I found there are all fit for making lime.

We from thence took the route that should carry us to our pettyaugre, a journey but of a few days. We drew the pettyaugre out of the water, and there passed the night. Next day we crossed the Missisippi ; in going up which we killed a shebear, with her cubs: for during the winter, the banks of the Missisippi are lined with them; and it is rare, in going up the river, not to see many cross it in a day, in search of food: the want of which makes them quit the banks.

I continued my route in going up the Missisippi quite to the Chicasaw Cliffs, (Ecores à Prud'homme) where I was told I should find something for the benefit of the colony: this was what excited my curiosity.

Being arrived at those cliffs we landed, and concealed, after unlading it, the pettyaugre in the water; and from that day I sought, and at length found the iron-mine, of which I had some hints given me. After being sure of this, I carefully searched all around, to find Castine: but this was impossible: however, I believe it may be found higher up in ascending the Missisippi, but that care I leave to those who hereafter shall choose to undertake the working that mine. I had, however, some amends made me for my trouble; as in searching, I found some marks of pit-coal in the neighbourhood, a thing at least as useful in other parts of the colony as in this.

After having made my reflections, I resolved in a little time to return home; but being loth to leave so fine a country, I penetrated a little farther into it; and in his short excursion I espied a small hill, all bare and parched, having on its top only two trees in a very drooping condition, and scarce any grass, besides some little tufts, distant enough asunder, which grew on a very firm clay. The bottom of this hill was not so barren, and the adjacent country fertile as in other parts. 
These indications made me presume there might be a mine in that spot.

I at length returned towards the Missisippi, in order to meet again the pettyaugre. As in all this country, and in all the height of the colony we find numbers of buffaloes, elk, deer, and other game; so we find numbers of wolves, some tigers, Cat-a-mounts, (Pichous) and carrion-crows, all of them carnivorous animals, which I shall hereafter describe. When we came near the Missisippi we made the signal of recognition, which was answered, though at some distance. It was there my people killed some buffaloes, to be dressed and cured in their manner, for our journey. We embarked at length, and went down the Missisippi, till we came within a league of the common landing-place. The Indians hid the pettyaugre, and went to their village. As for myself, I got home towards dusk, where I found my neighbours and slaves surprised, and at the same time glad, at my unexpected return, as if it had been from a hunting-match in the neighbourhood.

I was really well pleased to have got home, to see my slaves in perfect health, and all my affairs in good order: But I was strongly impressed with the beauties of the countries I had seen. I could have wished to end my days in those charming solitudes, at a distance from the tumultuous hurry of the world, far from the pinching gripe of avarice and deceit. There it is, said I to myself, one relishes a thousand innocent delights, and which are repeated with a satisfaction ever new. It is there one lives exempt from the assaults of censure, detraction, and calumny. In those delightsome meadows, which often extend far out of sight, and where we see so many different species of animals, there it is we have occasion to admire the beneficence of the Creator. To conclude, there it is, that at the gentle purling of a pure and living water, and enchanted with the concerts of birds, which fill the neighbouring thickets, we may agreeably contemplate the wonders of nature, and examine them all at our leisure.

I had reasons for concealing my journey, and stronger reasons still to suppress what I had discovered, in order to avail myself thereof afterwards: but the crosses I underwent, and 
the misfortunes of my life, have, to this day, prevented me from profiting by these discoveries, in returning to that charming country, and even so much as to lay them before the public.

CHAPTER III.

\section{Of the Nature of the Lands of Louisiana. The Lands on the Coast.}

IN order to describe the nature of this country with some method, I shall first speak of the place we land at, and shall therefore begin with the coast: I shall then go up the Missisippi; the reverse of what I did in the Geographical Description, in which I described that river from its source down to its mouth.

The coast, which was the first inhabited, extends from Rio Perdido to the lake of St. Louis: this ground is a very fine land, white as snow, and so dry, as not to be fit to produce any thing but pine, cedar, and some ever-green oaks.

The river Mobile is the most considerable of that coast to the east*. It rolls its waters over a pure sand, which cannot make it muddy. But if this water is clear, it partakes of the sterility of its bottom, so that it is far from abounding so much in fish as the Missisippi. Its banks and neighbourhood are not very fertile from its source down to the sea. The ground is stony, and scarce any thing but gravel, mixt with a little earth. Though these lands are not quite barren, there is a wide difference between their productions and those of the lands in the neighbourhood of the Missisippi. Mountains there are, but whether stone fit for building, I know not.

In the confines of the river of the Alibamous (Creeks) the lands are better: the river falls into the Mobile, above the bay of the same name. This bay may be about thirty leagues in length, after having received the Mobile, which runs from

* This river, which they call Mobile, and which after the rains of winter is a fine river in spring, is but a brook in summer, especially towards its source. Dumont, II, 228. 
north to south for about one hundred and fifty leagues. On the banks of this river was the first settlement of the French in Louisiana, which stood till New Orleans was founded, which is at this day the capital of the colony.

The lands and water of the Mobile are not only unfruitful in all kinds of vegetables and fish, but the nature of the waters and the soil contributes also to prevent the multiplication of animals; even women have experienced this. I understood by Madam Hubert, whose husband was at my arrival Commissary Director of the colony, that in the time the French were in that post, there were seven or eight barren women, who all became fruitful, after settling with their husbands on the banks of the Missisippi, where the capital was built, and whither the settlement was removed.

Fort St. Louis of Mobile was the French post. This fort stands on the banks of that river, near another small river, called Dog River, which falls into the bay to the south of the fort.

Though these countries are not so fertile as those in the neighbourhood of the Missisippi; we are, however, to observe, that the interior parts of the country are much better than those near the sea.

On the coast to the west of Mobile, we find islands not worth mentioning.

From the sources of the river of the Paska-Ogoulas, quite to those of the river of Quefoncté, which falls into the lake of St. Louis, the lands are light and fertile, but something gravelly, on account of the neighbourhood of the mountains that lie to the north. This country is intermixt with extensive hills, fine meadows, numbers of thickets, and sometimes with woods, thick set with cane, particularly on the banks of rivers and brooks; and is extremely proper for agriculture.

The mountains which I said these countries have to the north, form nearly the figure of a chaplet, with one end pretty near the Missisippi, the other on the banks of the Mobile. The inner part of this chaplet or chain is filled with hills; which 
are pretty fertile in grass, simples, fruits of the country, horsechesnuts, and wild-chesnuts, as large, and at least as good as those of Lyons.

To the north of this chain of mountains lies the country of the Chicasaws, very fine and free of mountains: it has only very extensive and gentle eminences, or rising grounds, fertile groves and meadows, which in springtime are all over red, from the great plenty of wood strawberries: in summer, the plains exhibit the most beautiful enamel, by the quantity and variety of the flowers: in autumn, after the setting fire to the grass, they are covered with mushrooms.

All the countries I have just mentioned are stored with game of every kind. The buffalo is found on the most rising grounds; the partridge in thick open woods, such as the groves in meadows; the elks delight in large forests, as also the pheasant; the deer, which is a roving animal, is every where to be met with, because in whatever place it may happen to be, it always has something to browse on. The ring-dove here flies in winter with such rapidity, as to pass over a great deal of country in a few hours; ducks and other aquatick game are in such numbers, that wherever there is water, we are sure to find many more than it is possible for us to shoot, were we to do nothing else; and thus we find game in every place, and fish in plenty in the rivers.

Let us resume the coast; which, though flat and dry, on account of its sand, abounds with delicious fish, and excellent shell-fish. But the crystal sand, which is pernicious to the sight by its whiteness, might it not be adapted for making some beautiful composition or manufacture? Here I leave the learned to find out what use this sand may be of.

If this coast is flat, it has in this respect an advantage; as we might say, Nature wanted to make it so, in order to be self-defended against the descent of an enemy.

Coming out of the Bay of Paska-Ogoulas, if we still proceed west, we meet in our way with the Bay of Old Biloxi, where a fort was built, and a settlement begun; but a great fire, spread by a violent wind, destroyed it in a few moments, which in prudence ought never to have been built at all. 
Those who settled at Old Biloxi could not, doubtless, think of quitting the sea-coast. They settled to the west, close to New-Biloxi, on a sand equally dry and pernicious to the sight. In this place the large grants happened to be laid off, which were extremely inconvenient to have been made on so barren a soil; where it was impossible to find the least plant or greens for any money, and where the hired servants died with hunger in the most fertile colony in the whole world.

In pursuing the same route and the same coast westward, the lands are still the same, quite to the small Bay of St. Louis, and to the Channels, which lead to the lake of that name. At a distance from the sea the earth is of a good quality, fit for agriculture; as being a light soil, but something gravelly. The coast to the north of the Bay of St. Louis is of a different nature, and much more fertile. The lands at a greater distance to the north of this last coast, are not very distant from the Missisippi; they are also much more fruitful than those to the east of this bay in the same latitude.

In order to follow the sea-coast down to the mouth of the Missisippi, we must proceed almost south, quitting the Channel. I have elsewhere mentioned, that we have to pass between Cat-Island, which we leave to the left, and Cockle-Island, which we leave to the right. In making this ideal route, we pass over banks almost level with the water, covered with a vast number of islets; we leave to the left the Candlemas-Isles, which are only heaps of sand, having the form of a gut cut in pieces; they rise but little above the sea, and scarcely yield a dozen of plants, just as in the neighbouring islets I have now mentioned. We leave to the right lake Borgne, which is another outlet of the lake St. Louis, and continuing the same route by several outlets for a considerable way, we find a little open clear sea, and the coast to the right, which is but a quagmire, gradually formed by a very soft ooze, on which some reeds grow. This coast leads soon to the East Pass or channel, which is one of the mouths of the Missisippi, and this we find bordered with a like soil, if indeed it deserves the name of soil.

There is, moreover, the South-east Pass, where stands Balise, and the South Pass, which projects farther into the sea. 
Balise is a fort built on an island of sand, secured by a great number of piles bound with good timber-work. There are lodgings in it for the officers and the garrison; and a sufficient number of guns for defending the entrance of the Missisippi. It is there they take the bar-pilot on board, in order to bring the ships into the river. All the passes and entrances of the Missisippi are as frightful to the eye, as the interior part of the colony is delightful to it.

The quagmires continue still for about seven leagues going up the Missisippi, at the entrance of which we meet a bar, three fourths of a league broad; which we cannot pass without the bar-pilot, who alone is acquainted with the channel.

All the west coast resembles that which I mentioned, from Mobile to the bay of St. Louis; it is equally flat, formed of a like sand, and a bar of isles, which lengthen out the coast, and hinder a descent; the coast continues thus, going westward, quite to Ascension Bay, and even a little farther. Its soil also is also barren, and in every respect like to that I have just mentioned.

I again enter the Missisippi, and pass with speed over these quagmires, incapable to bear up the traveller, and which only afford a retreat to gnats and moskittos, and to some water-fowl, which, doubtless, find food to live on, and that in security.

On coming out of these marshes, we find a neck of land on each side of the Missisippi; this indeed is firm land, but lined with marshes, resembling those at the entrance of the river. For the space of three or four leagues, this neck of land is at first bare of trees, but comes after to be covered with them, so as to intercept the winds, which the ships require, in order to go up the river to the capital. This land, though very narrow, is continued, together with the trees it bears, quite to the English Reach, which is defended by two forts; one to the right, the other to the left of the Missisippi.

The origin of the name, English Reach, (Detour aux Anglois) is differently assigned. I made enquiry of the oldest of the country, to what circumstance this Reach might owe its 
name. And they told me, that before the first settlement of the French in this colony, the English, having heard of the beauty of the country, which they had, doubtless, visited before, in going thither from Carolina by land, attempted to make themselves masters of the entrance of the Missisippi, and to go up the river, in order to fortify themselves on the first firm ground they could meet. Excited by that jealousy which is natural to them, they took such precautions as they imagined to be proper, in order to succeed.

The Indians on their part, who had already seen or heard of several people (French) having gone up and down the Missisippi at different times; the Indians, I say, who, perhaps, were not so well pleased with such neighbours, were still more frightened at seeing a ship enter the river, which determined them to stop its passage; but this was impossible, as long as the English had any wind, of which they availed themselves quite to this Reach. These Indians were the Ouachas and Chaouachas, who dwelt to the west of the Missisippi, and below this Reach. There were of them on each side of the river, and they lying in the canes, observed the English, and followed them as they went up, without daring to attack them.

When the English were come to the entrance of this Reach, the little wind they had failed them; observing besides, that the Missisippi made a great turn or winding, they despaired of succeeding; and wanted to moor in this spot, for which purpose they must bring a rope to land: but the Indians shot a great number of arrows at them, till the report of a cannon, fired at random, scattered them, and gave the signal to the English to go on board, for fear the Indians should come in greater numbers, and cut them to pieces.

Such is the origin of the name of this Reach. The Missisippi in this place forms the figure of a crescent, almost closed; so that the same wind which brings up a ship, proves often contrary, when come to the Reach; and this is the reason that ships moor, and go up towed, or tacking. This Reach is six or seven leagues; some assign it eight, more or less, according as they happen to make way. 
The lands on both sides of this Reach are inhabited, though the depth of soil is inconsiderable. Immediately above this Reach stands New Orleans, the capital of this colony, on the east of the Missisippi. A league behind the town, directly back from the river, we meet with a Bayouc or creek, which can bear large boats with oars. In following this Bayouc for the space of a league, we go to the lake St. Louis, and after traversing obliquely this last, we meet the Channels, which lead to Mobile, where I began my description of the nature of the soil of Louisiana.

The ground on which New Orleans is situated, being an earth accumulated by the ooze, in the same manner as is that both below and above, a good way from the capital, is of a good quality for agriculture, only that it is strong, and rather too fat. This land being flat, and drowned by the inundations for several ages, cannot fail to be kept in moisture, there being, moreover, only a mole or bank to prevent the river from overflowing it; and would be even too moist, and incapable of cultivation, had not this mole been made, and ditches, close to each other, to facilitate the draining off the waters: by this means it has been put in a condition to be cultivated with success.

From New Orleans to Manchac on the east of the Missisippi, twenty-five leagues above the capital, and quite to the Fork to the west, almost over-against Manchac, and a little way off, the lands are of the same kind and quality with those of New Orleans.

Chapter IV.

Quality of the Lands above the Fork. A Quarry of Stone for building. High Lands to the East: Their vast Fertility. West Coast: West Lands: Saltpetre.

10 the west, the Fork, the lands are pretty flat, but exempt from inundations. The part best known of these lands is called Baya-Ogoula, a name framed Bayouc and Ogoula, which signifies the nation dwelling near the Bayouc; there having been a nation of that name in that place, when the first French- 


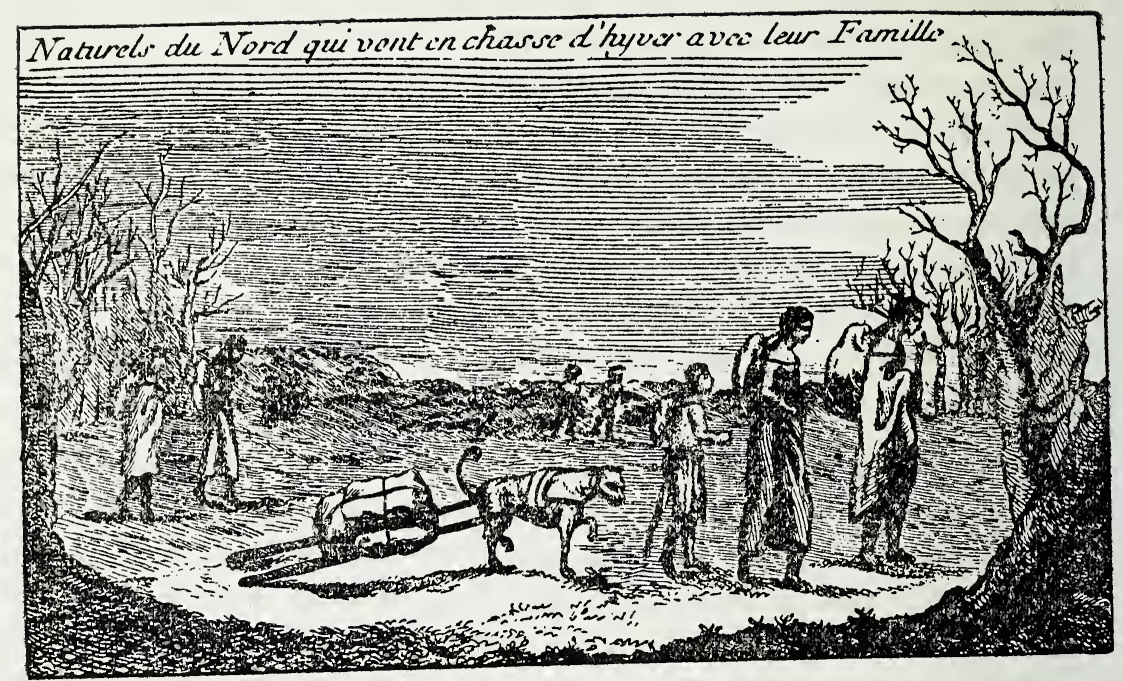

Indians of the North leaving in the winter with their families for a hunt

men came down the Missisippi; it lies twenty-five leagues from the capital.

But to the east, the lands are a good deal higher, seeing from Manchac to the river Wabache they are between an hundred and two hundred feet higher than the Missisippi in its greatest floods. The slope of these lands goes off perpendicularly from the Missisippi, which on that side receives but few rivers, and those very small, if we except the river of the Yasous, whose course is not above fifty leagues.

All these high lands are, besides, surmounted, in a good many places, by little eminences, or small hills, and rising grounds running off lengthwise, with gentle slopes. It is only when we go a little way from the Missisippi, that we find these high lands are over-topped by little mountains, which appear to be all of earth, though steep, without the least gravel or pebble being perceived on them.

The soil on these high lands is very good; it is a black light mold, about three feet deep on the hills or rising grounds. This upper earth lies upon a reddish clay, very strong and stiff; the lowest places between these hills are of the same nature, 
but there the black earth is between five and six feet deep. The grass growing in the hollows is of the height of a man, and very slender and fine; whereas the grass of the same meadow on the high lands rises scarce knee deep; as it does on the highest eminences, unless there is found something underneath, which not only renders the grass shorter, but even prevents its growth by the efficacy of some exhalations; which is not ordinarily the case on hills, though rising high, but only on the mountains properly so called.

My experience in architecture having taught me, that several quarries have been found under a clay like this, I was always of opinion there must be some in those hills.

Since I made these reflections, I have had occasion, in my journey to the country, to confirm these conjectures. We had set up our hut at the foot of an eminence, which was steep towards us, and near a fountain, whose water was lukewarm and pure.

This fountain appeared to me to issue out of a hole, which was formed by the sinking of the earth. I stooped in order to take a better view of it, and I observed stone, which to the eye appeared proper for building, and the upper part which was this clay, which is peculiar to the country. I was highly pleased to be thus ascertained, that there was stone fit for building in this colony, where it is imagined there is none, because it does not come out of the earth to shew-itself.

It is not to be wondered, that there is none to be found in the Lower Louisiana, which is only an earth accumulated by ooze; but it is far more extraordinary, not to see a flint, nor even a pebble on the hills, for upwards of an hundred leagues sometimes; however; this is a thing common in this province.

I imagine I ought to assign a reason for it, which seems pretty probable to me. This land has never been turned, or dug, and is very close above the clay, which is extremely hard, and covers the stone, which cannot shew itself through such a covering: it is therefore no such surprise, that we observe no stone out of the earth in these plains and on these eminences. 
All these high lands are generally meadows and forests of tall trees, with grass up to the knee. Along gullies they prove to be thickets, in which wood of every kind is found, and also the fruits of the country.

Almost all these lands on the east of the river are such as I have described; that is, the meadows are on those high grounds, whose slope is very gentle; we also find there tall forests, and thickets in the low bottoms. In the meadows we observe here and there groves of very tall and straight oaks, to the number of fourscore or an hundred at most: there are others of about forty or fifty, which seem to have been planted by men's hands in these meadows, for a retreat to the buffaloes, deer, and other animals, and a screen against storms, and the sting of the flies.

The tall forests are all hiccory, or all oak: in these last we find a great many morels; but then there grows a species of mushrooms at the feet of felled walnut-trees, which the Indians carefully gather; I tasted of them, and found them good.

The meadows are not only covered with grass fit for pasture, but produce quantities of wood-strawberries in the month of April; for the following months the prospect is charming; we scarce observe a pile of grass, unless what we tread under foot; the flowers, which are then in all their beauty, exhibit to the view the most ravishing sight, being diversified without end; one in particular I have remarked, which would adorn the most beautiful parterre; I mean the Lion's Mouth (la gueule de Lion).

These meadows afford not only a charming prospect to the eye; they, moreover, plentifully produce excellent simples, (equally with tall woods) as well for the purposes of medicine as of dying. When all these plants are burnt, and a small rain comes on, mushrooms of an excellent flavour succeed to them, and whiten the surface of the meadows all over.

Those rising meadows and tall forests abound with buffaloes, elk, and deer, with turkeys, partridges, and all kinds of game; consequently wolves, catamounts, and other carnivorous animals are found there; which, in following the other animals, destroy and devour such as are too old or too fat; and when the 
Indians go a hunting, these animals are sure to have the offal, or hound's fee, which makes them follow the hunters.

These high lands naturally produce mulberry-trees, the leaves of which are very grateful to the silk-worm. Indigo, in like manner, grows there along the thickets, without culture. There also a native tobacco is found growing wild, for the culture of which, as well as for other species of tobacco, these lands are extremely well adapted. Cotton is also cultivated to advantage: wheat and flax thrive better and more easily there, than lower down towards the capital, the land there being too fat; which is the reason that, indeed, oats come there to a greater height than in the lands I am speaking of; but the cotton and the other productions are neither so strong nor so fine there, and the crops of them are often less profitable, though the soil be of an excellent nature.

In fine, those high lands to the east of the Missisippi, from Manchac to the river Wabache, may and ought to contain mines: we find in them, just at the surface, iron and pit-coal, but no appearance of silver mines; gold there may be, copper also, and lead.

Let us return to Manchac, where I quitted the Missisippi; which I shall cross, in order to visit the west side, as I have already done the east. I shall begin with the west coast, which resembles that to the east; but is still more dry and barren on the shore. On quitting that coast of white and crystal sand, in order to go northward, we meet five or six lakes, which communicate with one another, and which are, doubtless, remains of the sea. Between these lakes and the Missisippi, is an earth accumulated on the sand, and formed by the ooze of that river, as I said; between these lakes there is nothing but sand, on which there is so little earth, that the sand-bottom appears to view; so that we find there but little pasture, which some strayed buffaloes come to eat; and no trees, if we except a hill on the banks of one of these lakes, which is all covered with ever-green oaks, fit for ship-building. This spot may be a league in length by half a league in breadth; and was called Barataria, because enclosed by these lakes and their outlets, to form almost an island on dry land. 
These lakes are stored with monstrous carp, as well for size as for length; which slip out of the Missisippi and its muddy stream, when overflowed, in search of clearer water. The quantity of fish in these lakes is very surprising, especially as they abound with vast numbers of alligators. In the neighbourhood of these lakes there are some petty nations of Indians, who partly live on this amphibious animal.

Between these lakes and the banks of the Missisippi, there is some thin herbage, and among others, natural hemp, which grows like trees, and very branched. This need not surprise us, as each plant stands very distant from the other: hereabouts we find little wood, unless when we approach the Missisippi.

To the west of these lakes we find excellent lands, covered in many places with open woods of tall trees, through which one may easily ride on horseback; and here we find some buffaloes, which only pass through these woods because the pasture under the trees is bitter; and therefore they prefer the grass of the meadows, which lying exposed to the rays of the sun, becomes thereby more savoury.

In going still farther west, we meet much thicker woods, because this country is extremely well watered; we here find numbers of rivers, which fall into the sea; and what contributes to the fertility of this land, is the number of brooks, that fall into these rivers.

This country abounds with deer and other game; buffailoes are rare; but it promises great riches to such as shall inhabit it, from the excellent quality of its lands. The Spaniards, who bound us on that side, are jealous enough: but the great quantities of land they possess in America, have made them lose sight of settling there, though acquainted therewith before us: however, they took some steps to traverse our designs, when they saw we had some thoughts that way. But they are not settled there as yet; and who could hinder us from making advantageous settlements in that country?

I resume the banks of the Missisippi, above the lakes, and the lands above the Fork, which, as I have sufficiently ac- 
quainted the reader, are none of the best; and I go up to the north, in order to follow the same method I observed in describing the nature of the lands to the east.

The banks of the Missisippi are of a fat and strong soil; but far less subject to inundations than the lands of the east. If we proceed a little way westward, we meet land gradually rising, and of an excellent quality; and even meadows, which we might well affirm to be boundless, if they were not intersected by little groves. These meadows are covered with buffaloes and other game, which live there so much the more peaceably, as they are neither hunted by men, who never frequent those countries; nor disquieted by wolves or tigers, which keep more to the north.

The country I have just described is such as I have represented it, till we come to New Mexico: it rises gently enough, near the Red River, which bounds it to the north, till we reach a high land, which was no more than five or six leagues in breadth, and in certain places only a league; it is almost flat, having but some eminences at some considerable distance from each other: we also meet some mountains of a middling height, which appear to contain something more than bare stone.

This high land begins at some leagues from the Missisippi, and continues so quite to New Mexico; it lowers towards the Red River, by windings, where it is diversified alternately with meadows and woods. The top of this height, on the contrary, has scarce any wood. A fine grass grows between the stones, which are common there. The buffaloes come to feed on this grass, when the rains drive them out of the plains; otherwise they go but little thither, because they find there neither water, nor saltpetre.

We are to remark, by the bye, that all cloven-footed animals are extremely fond of salt, and that Louisiana in general contains a great deal of saltpetre. And thus we are not to wonder, if the buffalo, the elk, and the deer, have a greater inclination to some certain places than to others, though they are there often hunted. We ought therefore to conclude, that there is more saltpetre in those places, than in such as they 
haunt but rarely. This is what made me remark, that these animals, after their ordinary repass, fail but rarely to go to the torrents, where the earth is cut, and even to the clay; which they lick, especially after rain, because they there find a taste of salt, which allures them thither. Most of those who have made this remark imagine that these animals eat the earth; whereas in such places they only go in quest of the salt, which to them is so strong an allurement as to make them bid defiance to dangers in order to get at it.

\section{Chapter V.}

Quality of the Lands of the Red River. Posts of the Nachitoches. A Silver Mine. Lands of the Black River.

THE Banks of the Red River, towards its confluence, are pretty low, and sometimes drowned by the inundations of the Missisippi; but above all, the north side, which is but a marshy land for upwards of ten leagues in going up to the Nachitoches, till we come to the Black River, which falls into the Red. This last takes its name from the colour of its sand, which is red in several places: it is also called the Marne, a name given it by some geographers, but unknown in the country. Some call it the River of the Nachitoches, because they dwell on its banks: but the appellation, Red River, has remained to it.

Between the Black River and the Red River the soil is but very light, and even sandy, where we find more firs than other trees; we also observe therein some marshes. But these lands, though not altogether barren, if cultivated, would be none of the best. They continue such along the banks of the river, only to the rapid part of it, thirty leagues from the Missisippi. This rapid part cannot justly be called a fall; however, we can scarce go up with oars, when laden, but must land and tow. I imagine, if the waterman's pole was used, as on the Loire and other rivers in France, this obstacle would be easily surmounted.

The south side of this river, quite to the rapid part, is entirely different from the opposite side; it is something high- 
er, and rises in proportion as it approaches to the height I have mentioned; the quality is also very different. This land is good and light, and appears disposed to receive all the culture imaginable, in which we may assuredly hope to succeed. It naturally produces beautiful fruit trees and vines in plenty; it was on that side muscadine grapes were found. The back parts have neater woods, and the meadows intersected with tall forests. On that side the fruit trees of the country are common; above all, the hiccory and walnut-trees, which are sure indications of a good soil.

From the rapid part to the Nachitoches, the lands on both sides of this river sufficiently resemble those I have just mentioned. To the left, in going up, there is a petty nation, called the Avoyelles, and known only for the services they have done the Colony by the horses, oxen, and cows they have brought from New Mexico for the service of the French in Louisiana. I am ignorant what view the Indians may have in that commerce: but I well know, that notwithstanding the fatigues of the journey, these cattle, one with another, did not come, after deducting all expenses, and even from the second hand, but to about two pistoles a head; whence I ought to presume, that they have them cheap in New Mexico. By means of this nation we have in Louisiana very beautiful horses, of the species of those of Old Spain, which, if managed or trained, people of the first rank might ride. As to the oxen and cows, they are the same as those of France, and both are at present very common in Louisiana.

The south side conveys into the Red River only little brooks. On the north side, and pretty near the Nachitoches, there is, as is said, a spring of water very salt, running only four leagues. This spring, as it comes out of the earth, forms a little river, which, during the heats, leaves some salt on its banks. And what may render this more credible is, that the country whence it takes its rise contains a great deal of mineral salt, which discovers itself by several springs of salt water, and by two salt lakes, of which I shall presently speak. In fine. in going up we come to the French fort of the Nachitoches, built in an island, formed by the Red River. 
This island is nothing but sand, and that so fine, that the wind drives it like dust; so that the tobacco attempted to be cultivated there at first was loaded with it. The leaf of the tobacco having a very fine down, easily retains this sand, which the least breath of air diffuses every where; which is the reason that no more tobacco is raised in this island, but provisions only, as maiz, potatoes, pompions, \&c. which cannot be damaged by the sands.

M. de St. Denis commanded at this place, where he insinuated himself into the good graces of the natives in such a manner, that, altho' they prefer death to slavery, or even to the government of a sovereign, however mild, yet twenty or twentyfive nations were so attached to his person, that, forgetting they were born free, they willingly surrendered themselves to him; the people and their Chiefs would all have him for their Grand Chief; so that at the least signal, he could put himself at the head of thirty thousand men, drawn out of those nations, which had of their own accord submitted themselves to his orders; and that only by sending them a paper on which he drew the usual hieroglyphics that represent war among them, with a large leg, which denoted himself. This was still the more surprising, as the greatest part of these people were on the Spanish territories, and ought rather to have attached themselves to them, than to the French, if it had not been for the personal merits of this Commander.

At the distance of seven leagues from the French Post, the Spaniards have settled one, where they have resided ever since M. de la Motte, Governor of Louisiana, agreed to that settlement. I know not by what fatal piece of policy the Spaniards were allowed to make this settlement; but I know, that, if it had not been for the French, the natives would never have suffered the Spaniards to settle in that place.

However, several French were allured to this Spanish settlement, doubtless imagining, that the rains which come from Mexico, rolled and brought gold along with them, which would cost nothing but the trouble of picking up. But to what purpose serves this beautiful metal, but to make the people vain and idle among whom it is so common, and to make them 
neglect the culture of the earth, which constitutes true riches, by the sweets it procures to man, and by the advantages it furnishes to commerce.

Above the Nachitoches dwell the Cadodaquious, whose scattered villages assume different names. Pretty near one of these villages was discovered a silver mine, which was found to be rich, and of a very pure metal. I have seen the assay of it, and its ore is very fine. This silver lies concealed in small invisible particles, in a stone of a chesnut colour, which is spongy, pretty light, and easily calcinable: however, it yields a great deal more than it promises to the eye. The assay of this ore was made by a Portuguese, who had worked at the mines of New Mexico, whence he made his escape. $\mathrm{He}$ appeared to be master of his business, and afterwards visited other mines farther north, but he ever gave the preference to that of the Red River.

This river, according to the Spaniards, takes its rise in 32 degrees of north latitude; runs about fifty leagues northeast; forms a great elbow, or winding to the east; then proceeding thence south-east, at which place we begin to know it, it comes and falls into the Missisippi, about $31^{\circ}$ and odd minutes.

I said above, that the Black River discharges itself into the Red, ten leagues above the confluence of this last with the Missisippi : we now proceed to resume that river, and follow its course, after having observed, that the fish of all those rivers which communicate with the Missisippi, are the same as to species, but far better in the Red and Black Rivers, because their water is clearer and better than that of the Missisippi, which they always quit with pleasure. Their delicate and finer flavour may also arise from the nourishment they take in those rivers.

The lands of which we are going to speak are to the north of the Red River. They may be distinguished into two parts; which are to the right and left of the Black River, in going up to its source, and even as far as the river of the Arkansas. It is called the Black River, because its depth gives it that colour, 
which is, moreover, heightened by the woods which line it throughout the Colony. All the rivers have their banks covered with woods; but this river, which is very narrow, is almost quite covered by the branches, and rendered of a dark colour in the first view. It is sometimes called the river of the Wachitas, because its banks were occupied by a nation of that name, who are now extinct. I shall continue to call it by its usual name.

The lands which we directly find on both sides are low, and continue thus for the space of three or four leagues, till we come to the river of the Taensas, thus denominated from a nation of that name, which dwelt on its banks. This river of the Taensas is, properly speaking, but a channel formed by the overflowings of the Missisippi, has its course almost parallel thereto, and separates the low lands from the higher. The lands between the Missisippi and the river of the Taensas are the same as in the Lower Louisiana.

The lands we find in going up the Black River are nearly the same, as well for the nature of the soil, as for their good qualities. They are rising grounds, extending in length, and which in general may be considered as one very extensive meadow, diversified with little groves, and cut only by the Black River and little brooks, bordered with wood up to their sources. Buffaloes and deer are seen in whole herds there. In approaching to the river of the Arkansas, deer and pheasants begin to be very common; and the same species of game is found there, as is to the east of the Missisippi; in like manner wood-strawberries, simples, flowers, and mushrooms. The only difference is, that this side of the Missisippi is more level, there being no lands so high and so very different from the rest of the country. The woods are like those to the east of the Missisippi, except that to the west there are more walnut and hiccory trees. These last are another species of walnut, the nuts of which are more tender, and invite to these parts a greater number of parrots. What we have just said, holds in general of this west side; let us now consider what is peculiar thereto. 
CHAPTER VI.

A Brook of Salt Water: Salt Lakes. Lands of the River of the Arkansas. Red veined Marble: Slate: Plaster. Hunting the Buffalo. The dry Sand-banks in the Missisippi.

A FTER we have gone up the Black River about thirty leagues, we find to the left a brook of salt water, which comes from the west. In going up this brook about two leagues, we meet with a lake of salt water, which may be two leagues in length, by one in breadth. A league higher up to the north, we meet another lake of salt water, almost as long and broad as the former.

This water, doubtless, passes through some mines of salt; it has the taste of salt, without that bitterness of the sea-water. The Indians come a great way off to this place, to hunt in winter, and make salt. Before the French trucked coppers with them, they made upon the spot pots of earth for this operation: and they returned home loaded with salt and dry provisions.

To the east of the Black River we observe nothing that indicates mines; but to the west one might affirm there should be some, from certain marks, which might well deceive pretended connoisseurs. As for my part, I would not warrant that there were two mines in that part of the country, which seems to promise them. I should rather be led to believe that they are mines of salt, at no great depth from the surface of the earth, which, by their volatile and acid spirits, prevent the growth of plants in those spots.

Ten or twelve leagues above this brook is a creek, near which those Natchez retreated, who escaped being made slaves with the rest of their nation, when the Messrs. Perier extirpated them on the east side of the river, by order of the Court.

The Black River takes its rise to the north-west of its confluence, and pretty near the river of the Arkansas, into which falls a branch from this rise or source; by means of which we may have a communication from the one to the other with a middling carriage. This communication with the river of the 
Arkansas is upwards of an hundred leagues from the Post of that name. In other respects, this Black River might carry a boat throughout, if cleared of the wood fallen into its bed, which generally traverses it from one side to the other. It receives some brooks, and abounds in excellent fish, and in alligators.

I make no doubt but these lands are very fit to bear and produce every thing that can be cultivated with success on the east of the Missisippi, opposite to this side, except the canton or quarter between the river of the Taensas and the Missisippi; that land, being subject to inundations, would be proper only for rice.

I imagine we may now pass on to the north of the river of the Arkansas, which takes its rise in the mountains adjoining to the east of Santa Fé. It afterwards goes up a little to the north, from whence it comes down to the south, a little lower than its source. In this manner it forms a line parallel almost with the Red River.

That river has a cataract or fall, at about an hundred and fifty leagues from its confluence. Before we come to this fall, we find a quarry of red-veined marble, one of slate, and one of plaster. Some travellers have there observed grains of gold in a little brook: but as they happened to be going in quest of a rock of emeralds, they deigned not to amuse themselves with picking up particles of gold.

This river of the Arkansas is stored with fish; has a great deal of water; having a course of two hundred and fifty leagues, and can carry large boats quite to the cataract. Its banks are covered with woods, as are all the other rivers of the country. In its course it receives several brooks or rivulets, of little consequence, unless we except that called the White River, and which discharges itself into the curve or elbow of that we are speaking of, and below its fall.

In the whole tract north of this river, we find plains that extend out of sight, which are vast meadows, intersected by groves, at no great distance from one another, which are all tall woods, where we might easily hunt the stag; great num- 
bers of which, as also of buffaloes, are found here. Deer also are very common.

From having seen those animals frightened at the least noise, especially at the report of a gun, I have thought of a method to hunt them, in the manner the Spaniards of New Mexico do, which would not scare them at all, and which would turn to the great advantage of the inhabitants, who have this game in plenty in their country. This hunting might be set about in winter, from the beginning of October, when the meadows are burnt, till the month of February.

This hunting is neither expensive nor fatiguing: horses are had very cheap in that country, and maintained almost for nothing. Each hunter is mounted on horseback, and armed with a crescent somewhat open, whose inside should be pretty sharp; the top of the outside to have a socket, to put in a handle: then a number of people on horseback to go in quest of a herd of buffaloes, and always attack them with the wind in their backs. As soon as they smell a man, it is true, they run away; but at the sight of the horses they will moderate their fears, and thus not precipitate their flight; whereas the report of a gun frightens them so as to make them run at full speed. In this chace, the lightest would run fast enough; but the oldest, and even the young of two or three years old, are so fat, that their weight would make them soon be overtaken: then the armed hunter may strike the buffalo with his crescent above each ham, and cut his tendons; after which he is easily mastered. Such as never saw a buffalo, will hardly believe the quantity of fat they yield: but it ought to be considered, that, continuing day and night in plentiful pastures of the finest and most delicious grass, they must soon fatten, and that from their youth. Of this we have an instance in a bull at the Natchez, which was kept till he was two years old, and grew so fat, that he could not leap on a cow, from his great weight; so that we were obliged to kill him, and got nigh an hundred and fifty pounds of tallow from him. His neck was near as big as his body.

From what I have said, it may be judged what profit such .hunters might make of the skins and tallow of those buffaloes; 
the hides would be large, and their wool would be still an additional benefit. I may add, that this hunting of them would not diminish the species, those fat buffaloes being ordinarily the prey of wolves, as being too heavy to be able to defend themselves.

Besides, the wolves would not find their account in attacking them in herds. It is well known that the buffaloes range themselves in a ring, the strongest without, and the weakest within. The strong standing pretty close together, present their horns to the enemy, who dare not attack them in this disposition. But wolves, like all other animals, have their particular instinct, in order to procure their necessary food. They come so near that the buffaloes smell them some way off, which makes them run for it. The wolves then advance with a pretty equal pace, till they observe the fattest out of breath. These they attack before and behind; one of them seizes on the buffalo by the hind-quarter, and overturns him, the others strangle him.

The wolves being many in a body, kill not what is sufficient for one alone, but as many as they can, before they begin to eat. For this is the manner of the wolf, to kill ten or twenty times more than he needs, especially when he can do it with ease, and without interruption.

Though the country I describe has very extensive plains, I pretend not to say that there are no rising grounds or hills; but they are more rare there than elsewhere, especially on the west side. In approaching to New Mexico we observe great hills and mountains, some of which are pretty high.

I ought not to omit mentioning here, that from the low lands of Louisiana, the Missisippi has several shoal banks of sand in it, which appear very dry upon the falling of the waters, after the inundations. These banks extend more or less in length; some of them half a league, and not without a considerable breadth. I have seen the Natchez, and other Indians, sow a sort of grain, which they called Choupichoul, on these dry sand-banks. This sand received no manner of culture; and the women and children covered the grain any how with their feet, without taking any great pains about it. After this sow- 
ing, and manner of culture, they waited till autumn, when they gathered a great quantity of the grain. It was prepared like millet, and very good to eat. This plant is what is called Belle Dame Sauvage*, which thrives in all countries, but requires a good soil: and whatever good quality the soil in Europe may have, it shoots but a foot and a half high; and yet, on this sand of the Missisippi, it rises, without any culture, three feet and a half, and four feet high. Such is the virtue of this sand all up the Missisippi ; or, to speak more properly, for the whole length of its course; if we except the accumulated earth of the Lower Louisiana, across which it passes, and where it cannot leave any dry sand-banks; because it is straitened within its banks, which the river itself raises, and continually augments.

In all the groves and little forests I have mentioned, and which lie to the north of the Arkansas, pheasants, partridges, snipes, and woodcocks, are in such great numbers, that those who are most fond of this game, might easily satisfy their longing, as also every other species of game. Small birds are still vastly more numerous.

* He seems to mean Buck-wheat.

\section{ChAPTER VII.}

The Lands of the River St. Francis. Mine of Marameg, and other Mines. A Lead Mine. A soft Stone resembling Porphyry. Lands of the Missouri. The Lands north of the Wabache. The Lands of the Illinois. De la Mothe's Mine, and other Mines.

THIRTY leagues above the river of the Arkansas, to the north, and on the same side of the Missisippi, we find the river St. Francis.

The lands adjoining to it are always covered with herds of buffaloes, nothwithstanding they are hunted every winter in those parts: for it is to this river, that is, in its neighbourhood, that the French and Canadians go and make their salt provisions for the inhabitants of the capital, and of the neighbour- 
ing plantations, in which they are assisted by the native Arkansas, whom they hire for that purpose. When they are upon the spot, they chuse a tree fit to make a pettyaugre, which serves for a salting or powdering-tub in the middle, and is closed at the two ends, where only is left room for a man at each extremity.

The trees they choose are ordinarily the poplar, which grow on the banks of the water. It is a white wood, soft and binding. The pettyaugres might be made of other wood, because such are to be had pretty large; but either too heavy for pettyaugres, or too apt to split.

The species of wood in this part of Louisiana is tall oak; the fields abound with four sorts of walnut, especially the black kind; so called, because it is of a dark brown colour, bordering on black; this sort grows very large.

There are besides fruit trees in this country, and it is there we begin to find commonly Papaws. We have also here other trees of every species, more or less, according as the soil is favourable. These lands in general are fit to produce every thing the low lands can yield, except rice and indigo. But in return, wheat thrives there extremely well: the vine is found every where; the mulberry-tree is in plenty; tobacco grows fine, and of a good quality; as do cotton and garden plants: so that by leading an easy and agreeable life in that country, we may at the same time be sure of a good return to France.

The land which lies between the Missisippi and the river St. Francis, is full of rising grounds, and mountains of a middling height, which, according to the ordinary indications, contain several mines: some of them have been assayed; among the rest, the mine of Marameg, on the little river of that name; the other mines appear not to be so rich, nor so easy to be worked. There are some lead mines, and others of copper, as is pretended.

The mine of Marameg, which is silver, is pretty near the confluence of the river which gives it name; which is a great advantage to those who would work it, because they might 
easily by that means have their goods from Europe. It is situate about five hundred leagues from the sea.

I shall continue on the west side of the Missisippi, and to the north of the famous river of Missouri, which we are now to cross. This river takes its rise at eight hundred leagues distance, as is alledged, from the place where it discharges itself into the Missisippi. Its waters are muddy, thick, and charged with nitre; and these are the waters that make the Missisippi muddy down to the sea, its waters being extremely clear above the confluence of the Missouri: the reason is, that the former rolls its waters over a sand and pretty firm soil; the latter, on the contrary, flows across rich and clayey lands, where little stone is to be seen; for though the Missouri comes out of a mountain, which lies to the north-west of New Mexico, we are told, that all the lands it passes through are generally rich; that is, low meadows, and lands without stone.

This great river, which seems ready to dispute the preeminence with the Missisippi, receives in its long course many rivers and brooks, which considerably augment its waters. But except those that have received their names from some nation of Indians who inhabit their banks, there are very few of their names we can be well assured of, each traveller giving them different appellations. The French having penetrated up the Missouri only for about three hundred leagues at most, and the rivers which fall into its bed being only known by the Indians, it is of little importance what names they may bear at present, being besides in a country but little frequented. The river which is the best known is that of the Osages, so called from a nation of that name, dwelling on its banks. It falls into the Missouri, pretty near its confluence.

The largest known river which falls into the Missouri, is that of the Canzas; which runs for near two hundred leagues in a very fine country. According to what I have been able to learn about the course of this great river, from its source to the Canzas, it runs from west to east; and from that nation it falls down to the southward, where it receives the river of the Canzas, which comes from the west; there it forms a great elbow, which terminates in the neighbourhood of the Missouri; 
then it resumes its course to the south-east, to lose at last both its name and waters in the Missisippi, about four leagues lower down than the river of the Illinois.

There was a French Post for some time in an island a few leagues in length, overagainst the Missouris; the French settled in this fort at the east-point, and called it Fort Orleans. M. de Bourgmont commanded there a sufficient time to gain the friendship of the Indians of the countries adjoining to this great river. He brought about a peace among all those nations, who before his arrival were all at war; the nations to the north being more war-like than those to the south.

After the departure of that commandant, they murdered all the garrison, not a single Frenchman having escaped to carry the news: nor could it be ever known whether it happened through the fault of the French, or through treachery.

As to the nature of that country, I refer to M. de Bourgmont's Journal, an extract from which I have given above. That is an original account, signed by all the officers, and several others of the company, which I thought was too prolix to give at full length, and for that reason I have only extracted from it what relates to the people and the quality of the soil, and traced out the route to those who have a mind to make that journey; and even this we found necessary to abridge in this translation.

In this journey of $M$. de Bourgmont, mention is only made of what we meet with from Fort Orleans, from which we set out, in order to go to the Padoucas: wherefore I ought to speak of a thing curious enough to be related, and which is found on the banks of the Missouri; and that is, a pretty high cliff, upright from the edge of the water. From the middle of this cliff juts out a mass of red stone with white spots, like porphyry, with this difference, that what we are speaking of is almost soft and tender, like sand-stone. It is covered with another sort of stone of no value; the bottom is an earth, like that on other rising grounds. This stone is easily worked, and bears the most violent fire. The Indians of the country have contrived to strike off pieces thereof with their arrows, 
and after they fall in the water plunge for them. When they can procure pieces thereof large enough to make pipes, they fashion them with knives and awls. This pipe has a socket two or three inches long, and on the opposite side the figure of a hatchet; in the middle of all is the boot, or bowl of the pipe, to put the tobacco in. These sort of pipes are highly esteemed among them.

All to the north of the Missouri is entirely unknown, unless we give credit to the relations of different travellers; but to which of them shall we give the preference? In the first place, they almost all contradict each other: and then, men of the most experience treat them as impostors; and therefore I choose to pay no regard to any of them.

Let us therefore now repass the Missisippi, in order to resume the description of the lands to the east, and which we quitted at the river Wabache. This river is distant from the sea four hundred and sixty (three hundred) leagues; it is reckoned to have four hundred leagues in length, from its source to its confluence into the Missisippi. It is called Wabache, though, according to the usual method, it ought to be called the Ohio, or Beautiful River; seeing the Ohio is known under that name in Canada, before its confluence was known: and as the Ohio takes its rise at a greater distance off than the three others, which mix together, before they empty themselves into the Missisippi, this should make the others lose their names; but custom has prevailed on the occasion*. The first river known to us, which falls into the Ohio, is that of the Miamis, which takes its rise towards lake Erié.

It is by this river of the Miamis that the Canadians come to Louisiana. For this purpose they embark on the river St. Laurence, go up this river, pass the cataracts quite to the bottom of Lake Erié, where they find a small river, on which they also go up to a place called the Carriage of the Miamis; because that people come and take their effects, and carry them on their backs for two leagues from thence to the banks of the river of their name, which I just said empties itself into

* But not among the English; we call it the Ohio. 
the Ohio. From thence the Canadians go down that river, enter the Wabache, and at last the Missisippi, which brings them to New Orleans, the capital of Louisiana. They reckon eighteen hundred leagues* from the capital of Canada to that of Louisiana, on account of the great turns and windings they are obliged to take.

The river of the Miamis is thus the first to the north, which falls into the Ohio; then that of the Chaouanons to the south; and lastly, that of the Cherakees; all which together empty themselves into the Missisippi. This is what we call the Wabache, and what in Canada and New England they call the Ohio. This river is beautiful, greatly abounding in fish, and navigable almost up to its source.

To the north of this river lies Canada, which inclines more to the east than the source of the Ohio, and extends to the country of the Illinois. It is of little importance to dispute here about the limits of these two neighbouring colonies, as they both appertain to France. The lands of the Illinois are reputed to be a part of Louisiana; we have there a post near a village of that nation, called Tamaroüas.

The country of the Illinois is extremely good, and abounds with buffalo and other game. On the north of the Wabache we begin to see the Orignaux; a species of animals which are said to partake of the buffalo and the stag; they have, indeed, been described to me to be much more clumsy than the stag. Their horns have something of the stag, but are shorter and more massy; the meat of them, as they say, is pretty good. Swans and other water-fowl are common in these countries.

The French Post of the Illinois is, of all the colony, that in which with the greatest ease they grow wheat, rye, and other like grain, for the sowing of which you need only to turn the earth in the slightest manner; that slight culture is sufficient to make the earth produce as much as we can reasonably desire. I have been assured, that in the last war, when the flour from France was scarce, the Illinois sent down to New Orleans upwards of eight hundred thousand weight thereof in

* It is but nine hundred leagues. 
one winter. Tobacco also thrives there, but comes to maturity with difficulty. All the plants transported thither from France succeed well, as do also the fruits.

In those countries there is a river, which takes its name from the Illinois. It was by this river that the first travellers came from Canada into the Missisippi. Such as come from Canada, and have business only on the Illinois, pass that way yet: but such as want to go directly to the sea, go down the river of the Miamis into the Wabache, or Ohio, and from thence into the Missisippi.

In this country there are mines, and one in particular, called De la Mothe's mine, which is silver, the assay of which has been made; as also of two lead-mines, so rich at first as to vegetate, or shoot a foot and a half at least out of the earth.

The whole continent north of the river of the Illinois is not much frequented, consequently little known. The great extent of Louisiana makes us presume, that these parts will not soon come to our knowledge, unless some curious person should go thither to open mines, where they are said to be in great numbers, and very rich.

\section{CHAPTER VIII.}

Of the Agriculture, or Manner of cultivating, ordering, and manufacturing the Commodities that are proper Articles of Commerce. Of the Culture of Maiz, Rice, and other Fruits of the Country. Of the Silk-worm.

IN order to give an account of the several sorts of plants cultivated in Louisiana, I begin with Maiz, as being the most useful grain, seeing it is the principal food of the people of America, and that the French found it cultivated by the Indians.

Maiz, which in France we call Turkey corn, (and we Indian-corn) is a grain of the size of a pea; there is of it as large as our sugar-pea: it grows on a sort of husks, (Quenouille) in ascending rows: some of these husks have to the 
number of seven hundred grains upon them, and I have counted even to a greater number. This husk may be about two inches thick, by seven or eight inches and upwards in length: it is wrapped up in several covers or thin leaves, which screen it from the avidity of birds. Its foot or stalk is often of the same size: it has leaves about two inches and upwards broad, by two feet and a half long, which are chanelled, or formed like gutters, by which they collect the dew which dissolves at sun-rising, and trickles down to the stalk, sometimes in such plenty, as to wet the earth around them for the breadth of six or seven inches. Its flower is on the top of the stalk, which is sometimes eight feet high. We ordinarily find five or six ears on each stalk, and in order to procure a greater crop, the part of the stalk above the ears ought to be cut away.

For sowing the Maiz in a field already cleared and prepared, holes are made four feet asunder every way, observing to make the rows as straight as may be, in order to weed them the easier: into every hole five or six grains are put, which are previously to be steeped for twenty-four hours at least, to make them rise or shoot the quicker, and to prevent the fox and birds from eating such quantities of them: by day there are people to guard them against birds; by night fires are made at proper distances to frighten away the fox, who would otherwise turn up the ground, and eat the corn of all the rows, one after another, without omitting one, till he has his fill, and is therefore the most pernicious animal to this corn. The corn, as soon as shot out of the earth, is weeded: when it mounts up, and its stalks are an inch big, it is hilled, to secure it against the wind. This grain produces enough for two negroes to make fifty barrels, each weighing an hundred and fifty pounds.

Such as begin a plantation in woods, thick set with cane, have an advantage in the Maiz, that makes amends for the labour of clearing the ground; a labour always more fatiguing than cultivating a spot already cleared. The advantage is this: they begin with cutting down the canes for a great extent of ground; the trees they peel two feet high quite round: this operation is performed in the beginning of March, as then the sap is in motion in that country: about fifteen days after, the canes, 
being dry, are set on fire: the sap of the trees are thereby made to descend, and the branches are burnt, which kills the trees.

On the following day they sow the corn in the manner I have just shewn: the roots of the cane, which are not quite dead, shoot fresh canes, which are very tender and brittle; and as no other weeds grow in the field that year, it is easy to be weeded of these canes, and as much corn again may be made, as in a field already cultivated.

This grain they eat in many different ways; the most common way is to make it into Sagamity, which is a kind of gruel made with water, or strong broth. They bake bread of it like cakes (by baking it over the fire on an iron plate, or on a board before the fire,) which is much better than what they bake in the oven, at least for present use; but you must make it every day; and even then it is too heavy to soak in soup of any kind. They likewise make Parched Meal* of it, which is a dish of the natives, as well as the Cooedlou, or bread mixt with beans. The ears of corn roasted are likewise a peculiar dish of theirs; and the small corn dressed in that manner is as agreeable to us as to them. A light and black earth agrees much better with the Maiz than a strong and rich one.

The Parched Meal is the best preparation of this corn; the French like it extremely well, no less than the Indians themselves: I can affirm that it is a very good food, and at the same time the best sort of provision that can be carried on a journey, because it is refreshing and extremely nourishing.

As for the small Indian corn, you may see an account of it in the first chapter of the third Book; where you will likewise find an account of the way of sowing wheat, which if you do not observe, you may as well sow none.

Rice is sown in a soil well laboured, either by the plough or hoe, and in winter, that it may be sowed before the time of the inundation. It is sown in furrows of the breadth of a hoe: when shot, and three or four inches high, they let water into the furrows, but in a small quantity, in proportion as it grows, and then give water in greater plenty.

* See Book III, Chap. I. 
The ear of this grain nearly resembles that of oats; its grains are fastened to a beard, and its chaff is very rough, and full of those fine and hard beards: the bran adheres not to the grain, as that of the corn of France; it consists of two lobes, which easily separate and loosen, and are therefore readily cleaned and broke off.

They eat their rice as they do in France, but boiled much thicker, and with much less cookery, although it is not inferior in goodness to ours: they only wash it in warm water, taken out of the same pot you are to boil it in, then throw it in all at once, and boil it till it bursts, and so it is dressed without any further trouble. They make bread of it that is very white and of a good relish; but they have tried in vain to make any that will soak in soup.

The culture of the Water-melon is simple enough. They choose for the purpose a light soil, as that of a rising ground, well exposed: they make holes in the earth, from two and a half to three feet in diameter, and distant from each other fifteen feet every way, in each of which holes they put five or six seeds. When the seeds are come up, and the young plants have struck out five or six leaves, the four most thriving plants are pitched upon, and the others plucked up to prevent their starving each other, when too numerous. It is only at that time that they have the trouble of watering them, nature alone performing the rest, and bringing them to maturity; which is known by the green rind beginning to change colour. There is no occasion to cut or prune them. The other species of melons are cultivated in the same manner, only that between the holes the distance is but five or six feet.

All sorts of garden plants and greens thrive extremely well in Louisiana, and grow in much greater abundance than in France: the climate is warmer, and the soil much better. However, it is to be observed, that onions and other bulbous plants answer not in the low lands, without a great deal of pains and labour; whereas in the high grounds they grow very large and of a fine flavour.

The inhabitants of Louisiana may very easily make Silk, having mulberries ready at hand, which grow naturally in the 
high lands, and plantations of them may be easily made. The leaves of the natural mulberries of Louisiana are what the silkworms are very fond of; I mean the more common mulberries with a large leaf, but tender, and the fruit of the colour of Burgundy wine. The province produces also the White Mulberry, which has the same quality with the red.

I shall next relate some experiments that have been made on this subject, by people who were acquainted with it. Madam Hubert, a native of Provence, where they make a great deal of silk, which she understood the management of, was desirous of trying whether they could raise silk-worms with the mulberry leaves of this province, and what sort of silk they would afford. The first of her experiments was, to give some large silk-worms a parcel of the leaves of the Red Mulberry, and another parcel of the White Mulberry both upon the same frame. She observed the worms went over the leaves of both sorts, without shewing any greater liking to the one than to the other: then she put to the other two sorts of leaves some of the leaves of the White-sweet or Sugar-Mulberry, and she found that the worms left the other sorts to go to these, and that they preferred them to the leaves of the common Red and White Mulberry*.

The second experiment of Madam Hubert was, to raise and feed some silk-worms separately. To some she gave the leaves of the common White Mulberry, and to others the leaves of the White Sugar-Mulberry; in order to see the difference of the silk from the difference of their food. Moreover, she raised and fed some of the native silk-worms of the country, which were taken very young from the mulberry-trees; but she observed that these last were very flighty, and did nothing but run up and down, their nature being, without doubt, to live upon trees: she then changed their place, that they might not mix with the other worms that came from France, and gave them little branches with the leaves on them, which made them a little more settled.

* See an account of these different sorts of Mulberry, in the notes at the end of this Volume. 
This industrious lady waited till the cocoons were perfectly made, in order to observe the difference between them in unwinding the silk; the success of which, and of all her other experiments, she was so good as to give me a particular account of. When the cocoons were ready to be wound, she took care of them herself, and found that the wild worms yielded less silk than those from France; for although they were of a larger size, they were not so well furnished with silk, which proceeded, no doubt, from their not being sufficiently nourished, by their running incessantly up and down; and accordingly she observed that they were but meagre; but notwithstanding, their silk was strong and thick, though coarse.

Those who were fed with the leaves of the Red Mulberry made cocoons well furnished with silk; which was stronger and finer than that of France. Those that were fed upon the leaves of the common White Mulberry, had the same silk with those that were fed on the leaves of the Red Mulberry. The fourth sort, again, that had been fed with the leaves of the White Sugar-Mulberry, had but little silk; it was indeed as fine as the preceding, but it was so weak and so brittle, that it was with great difficulty they could wind it.

These are the experiments of this lady on silk-worms, which every one may make his own uses of, in order to have the sorts of silk, mulberries, or worms, that are most suitable to his purpose, and most likely to turn to his account: which we are very glad of this opportunity to inform them of, that they may see how much society owes to those persons who take care to study nature, in order to promote industry and public utility.

\section{Chapter IX.}

Of Indigo, Tobacco, Cotton, Wax, Hops, and Saffron.

THE high lands of Louisiana produce a natural Indigo: what

I saw in two or three places where I have observed it, grew at the edges of the thick woods, which shews it delights in a good, but light soil. One of these stalks was but ten or twelve inches high, its wood at least three lines in diameter, and of as 


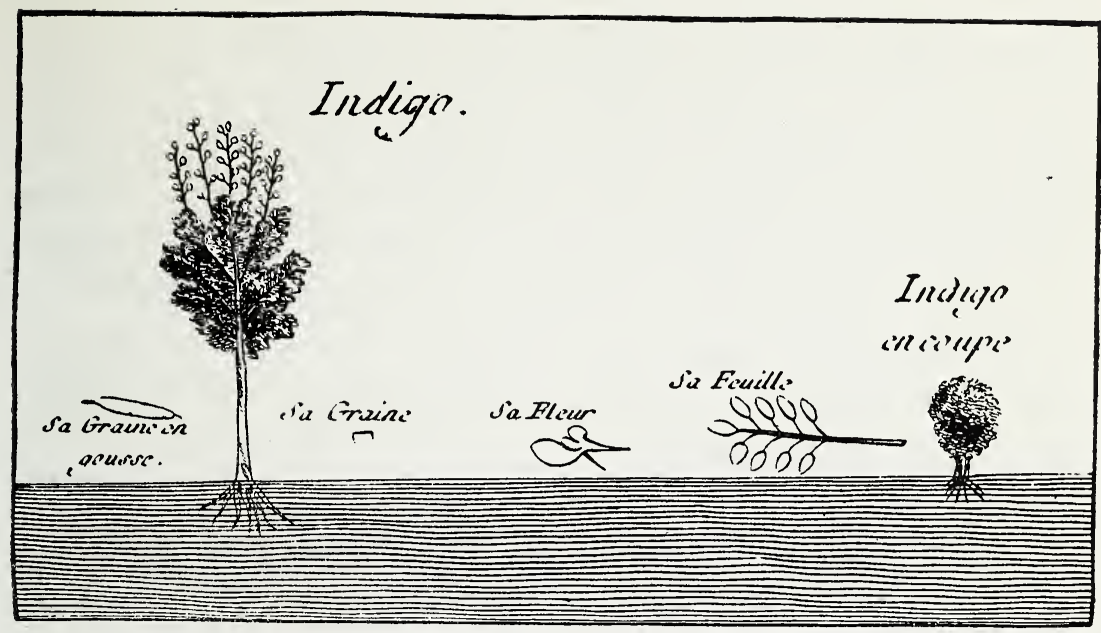

fine a green as its leaf; it was as tender as the rib of a cabbage leaf; when its head was blown a little, the two other stalks shot in a few days, the one seventeen, the other nineteen inches high; the stem was six lines thick below, and of a very lively green, and still very tender, the lower part only began to turn brown a little; the tops of both were equally ill furnished with leaves, and without branches; which makes it to be presumed, that being so thriving and of so fine a growth, it would have shot very high, and surpass in vigour and heighth the cultivated Indigo. The stalk of the Indigo, cultivated by the French at the Natchez, turned brown before it shot eleven or twelve inches; when in seed it was five feet high and upwards, and surpassed in vigour what was cultivated in the Lower Louisiana, that is, in the quarter about New Orleans : but the natural, which I had an opportunity of seeing only young and tender, promised to become much taller and stouter than ours, and to yield more.

The Indigo cultivated in Louisiana comes from the islands; its grain is of the bigness of one line, and about a quarter longer, brown and hard, flatted at the extremities, because it is compressed in its pod. This grain is sown in a soil prepared like a garden, and the field where it is cultivated is called the Indigo-garden. In order to sow it, holes are made on a straight line with a small hoe, a foot asunder; in each hole four or five 
seeds are put, which are covered with earth; great care is had not to suffer any strange plants to grow near it, which would choak it; and it is sown a foot asunder, to the end it may draw the fuller nourishment, and be weeded without grazing or ruffling the leaf, which is that which gives the Indigo. When its leaf is quite come to its shape, it resembles exactly that of the Acacia, so well known in France, only that it is smaller.

It is cut with large pruning-knives, or a sort of sickles, with about six or seven inches aperture, which should be pretty strong. It ought to be cut before its wood hardens; and to be green as its leaf, which ought, however, to have a bluish eye or cast. When cut it is conveyed into the rotting-tub, as we shall presently explain. According as the soil is better or worse, it shoots higher or lower; the tuft of the first cutting, which grows round, does not exceed eight inches in heighth and breadth: the second cutting rises sometimes to a foot. In cutting the Indigo you are to set your foot upon the root, in order to prevent the pulling it out of the earth; and to be upon your guard not to cut yourself, as the tool is dangerous.

In order to make an Indigo-work, a shed is first of all to be built: this building is at least twenty feet high, without walls or flooring, but only covered. The whole is built upon posts, which may be closed with mats, if you please: this building has twenty feet in breadth, and at least thirty in length. In this shed three vats or large tubs are set in such a manner, that the water may be easily drained off from the first, which is the lowermost and smallest. The second rests with the edge of its bottom on the upper edge of the first, so that the water may easily run from it into the one below. This second vat is not broader but deeper than the first, and is called the Battery; for this reason it has its beaters, which are little buckets formed of four ends of boards, about eight inches long, which together have the figure of the hopper of a mill; a stick runs across them, which is put into a wooden fork, in order to beat the Indigo: there are two of them on each side, which in all make four.

The third vat is placed in the same manner over the second, and is as big again, that it may hold the leaves; it is called the 
Rotting-tub, because the leaves which are put into it are deadened, not corrupted or spoiled therein. The Indigo-operator, who conducts the whole work, knows when it is time to let the water into the second vat; then he lets go the cock; for if the leaves were left too long, the Indigo would be too black; it must have no more time than what is sufficient to discharge a kind of flower or froth that is found upon the leaf.

The water, when it is all in the second vat, is beat till the Indigo-operator gives orders to cease; which he does not before he has several times taken up some of this water with a silver cup, by way of assay, in order to know the exact time in which they ought to give over beating the water: and this is a secret which practice alone can teach with certainty.

When the Indigo-operator finds that the water is sufficiently beaten, he lets it settle till he can draw off the water clear; which is done by means of several cocks one above another, for fear of losing the Indigo. For this purpose, if the water is clear, the highest cock is opened, the second in like manner, till the water is observed to be tinged; then they shut the cock: the same is done in all the cocks till all the Indigo be in a pap at the bottom of the second vat. The first, or small vat, serves only to purify the water which is found to be tinged, and let run while clear.

When the Indigo is well settled, they put it in cloth bags a foot and six inches wide, with a small circle at top, which helps to receive the Indigo with ease; it is suffered to drain till it gives no more water: however, it must be moist enough to spread it in the mould with a wooden knife or spatula.

In order to have the seed, they suffer it to run up as many feet as they foresee shall be necessary for seed; it shoots four or five feet high, according to the quality of the soil. There are four cuttings of it in the islands, where the climate is warmer; three good cuttings are made in Louisiana, and of as good a quality at least as in the islands.

Tobacco, which was found among the Indians of Louisiana, seems also to be a native of the country, seeing their ancient tradition informs us, that from time immemorial they 
have, in their treaties of peace and in their embassies, used the pipe, the principal use of which is that the deputies shall all smoke therein. This native Tobacco is very large; its stalk, when suffered to run to seed, shoots to five feet and a half and six feet; the lower part of its stem is at least eighteen lines in diameter, and its leaves often near two feet long, which are thick and succulent, its juice is strong, but never disorders the head. The Tobacco of Virginia has a broader but shorter leaf; its stalk is smaller, and runs not up so high; its smell is not disagreeable, but not so strong; it takes more plants to make a pound, because its leaf is thinner, and not so full of sap as the native. What is cultivated in the Lower Louisiana is smaller, and not so strong; but that made in the islands is thinner than that of Louisiana, but much stronger, and disorders the head.

In order to sow Tobacco, you make a bed on the best piece of ground you are master of, and give it six inches in heighth; this earth you beat and make level with the back of a spade; you afterwards sow the seed, which is extremely fine, nearly resembling poppy seed. It must be sown thin, and notwithstanding that attention, it often happens to be too thick. When the seed is sown, the earth is no longer stirred, but the seed is covered with ashes the thickness of a farthing, to prevent the worms from eating the tobacco when it is just shooting out of the earth.

As soon as the tobacco has four leaves, it is transplanted into a soil prepared for it, put into holes a foot broad made in a line, and distant three feet every way; a distance not too great, in order to weed it with ease, without breaking the leaves.

The best time for transplanting it is after rain, otherwise you must water it: in like manner, when the seed is in the earth, if it rains not, you must gently sprinkle it towards evening, because it is somewhat slow in rising, and when it is sprouted it requires a little water. You must lightly cover the plant in the day time with some leaves plucked the night before; a precaution on no account to be dispensed with, till the young plant has fully struck root. You must also daily visit the 
tobacco, to clear it of caterpillars, which fasten upon it, and would entirely eat it up, if they are not destroyed. The tobacco-caterpillar is of the shape of a silk-worm, has a prickle on its back towards its extremity; its colour is of the most beautiful sea-green, striped with silver-streaks; in a word, it is as beautiful to the eye as it is fatal to the plant it is fond of.

I gave great attention to keep my plantation clear of all weeds, observing in weeding it with the hoe not to touch the stalks, about which I caused to lay new earth, as well to secure them against gusts of wind, as to enable them to draw from the earth a more abundant nourishment. When the tobacco began to put forth suckers, I plucked them off, because they would have shot into branches, which would impoverish the leaves, and for the same reason stopped the tobacco from shooting above the twelfth leaf, afterwards stripping off the four lowermost, which never come to any thing. Hitherto I did nothing but what was ordinarily done by those who cultivate tobacco with some degree of care; but my method of proceeding afterwards was different.

I saw my neighbours strip the leaves of tobacco from the stalk, string them, set them to dry, by hanging them out in the air, then put them in heaps, to make them sweat. As for me, I carefully examined the plant, and when I observed the stem begin to turn yellow here and there, I caused the stalk to be cut with a pruning-knife, and left it for some time on the earth to deaden. Afterwards it was carried off, on handbarrows, because it is thus less exposed to be broken than on the necks of negroes. When it was brought to the house, I caused it to be hung up, with the big end of the stem turned upwards, the leaves of each stalk slightly touching one another, being well assured they would shrivel in drying, and no longer touch each other. It hereby happened, that the juice contained in the pith (sometimes as big as one's finger) of the stem of the plant, flowed into the leaves, and augmenting their sap, made them much more mild and waxy. As fast as these leaves assumed a bright chesnut colour, I stripped them from the stalk, and made them directly into bundles, which I wrapped up in a cloth, and bound it close with a cord for twenty four hours: 
then undoing the cloth, they were tied up closer still. This tobacco turned black and so waxy, that it could not be rasped in less than a year; but then it had a substance and flavour so much the more agreeable, as it never affected the head; and so I sold it for double the price of the common.

The cotton which is cultivated in Louisiana, is of the species of the white Siam*, though not so soft, nor so long as the silk-cotton; it is extremely white and very fine, and a very good use may be made of it. This cotton is produced, not from a tree, as in the East -Indies, but from a plant, and thrives much better in light than in strong and fat lands, such as those of the Lower Louisiana, where it is not so fine as on the high grounds.

This plant may be cultivated in lands newly cleared, and not yet proper for tobacco, much less for indigo, which requires a ground well worked like a garden. The seeds of cotton are planted three feet asunder, more or less according to the quality of the soil: the field is weeded at the proper season, in order to clear it of the noxious weeds, and fresh earth laid to the root of the plant, to secure it against the winds. The cotton requires weeding, neither so often, nor so carefully as other plants; and the care of gathering is the employment of young people, incapable of harder labour.

When the root of the cotton is once covered with fresh earth, and the weeds are removed, it is suffered to grow without further touching it, till it arrives to maturity. Then its heads or pods open into five parts, and expose their cotton to view. When the sun has dried the cotton well, it is gathered in a proper manner, and conveyed into the conservatory; after which comes on the greatest task, which is to separate it from the grain or seed to which it closely adheres; and it is this part of the work, which disgusts the inhabitants in the cultivation

\footnotetext{
* This East-India annual cotton has been found to be much better and whiter than what is cultivated in our colonies, which is of the Turkey kind. Both of them keep their colour better in washing, and are whiter than the perennial cotton that comes from the islands, although this last is of a longer staple.
} 


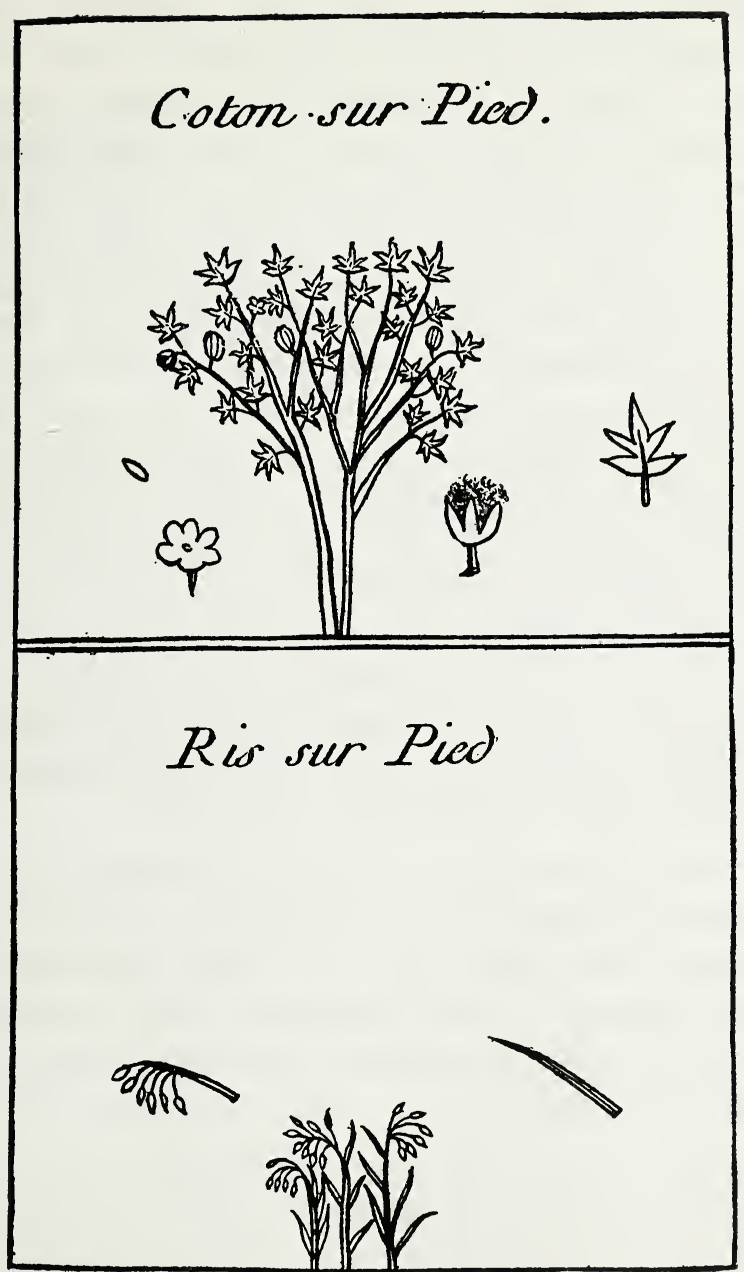

TOP: Cotton on the stalk-Воттом: Rice on the stalk

of it. I contrived a mill for the purpose, tried it, and found it to succeed, so as to dispatch the work very much.

The culture of indigo, tobacco, and cotton, may be easily carried on without any interruption to the making of silk, as any one of these is no manner of hindrance to the other. In the first place, the work about these three plants does not come on till after the worms have spun their silk: in the second place, 
the feeding and cleaning the silk-worm requires no great degree of strength; and thus the care employed about them interrupts no other sort of work, either as to time, or as to the persons employed therein. It suffices for this operation to have a person who knows how to feed and clean the worms; young negroes of both sexes might assist this person, little skill sufficing for this purpose: the oldest of the young negroes, when taught, might shift the worms and lay the leaves; the other young negroes gather and fetch them; and all this labour, which takes not up the whole day, lasts only for about six weeks. It appears therefore, that the profit made of the silk is an additional benefit, so much the more profitable, as it diverts not the workmen from their ordinary tasks. If it be objected, that buildings are requisite to make silk to advantage; I answer, buildings for the purpose cost very little in a country where wood may be had for taking; I add farther, that these buildings may be made and daubed with mud by any persons about the family; and besides, may serve for hanging tobacco in, two months after the silk-worms are gone.

I own I have not seen the wax-tree cultivated in Louisiana; people content themselves to take the berries of this tree, without being at pains to rear it; but as I am persuaded it would be very advantageous to make plantations of it, I shall give my sentiments on the culture proper for this tree, after the experiments I made in regard to it.

I had some seeds of the wax-tree brought me to Fontenai le Comte, in Poictou, some of which I gave to several of my friends, but not one of them came up. I began to reflect, that Poictou not being by far so warm as Louisiana, these seeds would have difficulty to shoot; I therefore thought it was necessary to supply by art the defect of nature; I procured horse, cow, sheep, and pigeon's dung in equal quantity, all which I put in a vessel of proportionable size, and poured on them water, almost boiling, in order to dissolve their salts: this water I drew off, and steeped the grains in a sufficient quantity thereof for forty-eight hours; after which I sowed them in a box full of good earth; seven of them came up, and made shoots between seven and eight inches high, but they were all 
killed by the frost for want of putting them into the greenhouse.

This seed having such difficulty to come up, I presume that the wax, in which it is wrapped up, hinders the moisture from penetrating into, and making its kernel shoot; and therefore I should think that those who choose to sow it, would do well if they previously rolled it lightly between two small boards just rough from the saw; this friction would cause the pellicle of wax to scale off with so much the greater facility, as it is naturally very dry; and then it might be put to steep.

Hops grow naturally in Louisiana, yet such as have a desire to make use of them for themselves, or sell them to brewers, cultivate this plant. It is planted in alleys, distant asunder six feet, in holes two feet and one foot deep, in which the root is lodged. When shot a good deal, a pole of the size of one's arm, and between twelve and fifteen feet long, is fixed in the hole; care is had to direct the shoots towards it, which fail not to run up the pole. When the flower is ripe and yellowish, the stem is cut quite close to the earth and the pole pulled out, in order to pick the flowers, which are saved.

If we consider the climate of Louisiana, and the quality of the high lands of that province, we might easily produce saffron there. The culture of this plant would be so much the more advantageous to the planters, as the neighbourhood of Mexico would procure a quick and useful vent for it.

\section{ChAPTER X.}

Of the Commerce that, and may be carried on in Louisiana. Of the Commodities which that Province may furnish in return for those of Europe. Of the Commerce of Louisiana with the Isles.

I HAVE often reflected on the happiness of France in the portion which Providence has allotted her in America. She has found in her lands neither the gold nor silver of Mexico and Peru, nor the precious stones and rich stuffs of the EastIndies; but she will find therein, when she pleases, mines of iron, lead, and copper. She is there possessed of a fertile soil, 
which only requires to be occupied in order to produce not only all the fruits necessary and agreeable to life, but also all the subjects on which human industry may exercise itself in order to supply our wants. What I have already said of Louisiana ought to make this very plain; but to bring the whole together, in order, and under one point of view, I shall next relate every thing that regards the commerce of this province.

Commodities which Louisiana may furnish in return for those of Europe.

FRANCE might draw from this colony several sorts of furs, which would not be without their value, though held cheap in France; and by their variety, and the use that might be made of them, would yield satisfaction. Some persons have dissuaded the rtaders from taking any furs from the Indians, on a supposition that they would be moth-eaten when carried to New-Orleans, on account of the heat of the climate: but I am acquainted with people of the business, who know how to preserve them from such an accident.

Dry buffalo hides are of sufficient value to encourage the Indians to procure them, especially if they were told, that only their skins and tallow were wanted; they would then kill the old bulls, which are so fat as scarce to be able to go: each buffalo would yield at least a hundred pounds of tallow; the value of which, with the skin, would make it worth their while to kill them, and thus none of our money would be sent to Ireland in order to have tallow from that country; besides the species of buffaloes would not be diminished, because these fat buffaloes are always the prey of wolves.

Deer-skins, which were bought of the Indians at first, did not please the manufacturers of Niort, where they are dressed, because the Indians altered the quality by their way of dressing them; but since these skins have been called for without any preparation but taking off the hair, they make more of them, and sell them cheaper than before.

The wax-tree produces wax, which being much drier than bees-wax, may bear mixture, which will not hinder its lasting longer than bees-wax. Some of this wax was sent to Paris to 
a factor of Louisiana, who set so low a price upon it as to discourage the planters from sowing any more. The sordid avarice of this factor has done a service to the islands, where it gives a higher price than that of France.

The islands also draw timber for building from Louisiana, which might in time prevent France from making her profits of the beauty, goodness, and quantity of wood of this province. The quality of the timber is a great inducement to build docks there for the construction of ships: the wood might be had at a low price of the inhabitants, because they would get it in winter, which is almost an idle time with them. This labour would also clear the grounds, and so this timber might be had almost for nothing. Masts might be also had in the country, on account of the number of pines which the coast produces; and for the same reason pitch and tar would be common. For the planks of ships, there is no want of oak; but might not very good one be made of cypress? this wood is, indeed, softer than oak, but endowed with qualities surpassing this last: it is light, not apt to split or warp, is supple and easily worked; in a word, it is incorruptible both in air and water; and thus making the planks stouter than ordinary, there would be no inconvenience from the use of cypress. I have observed, that this wood is not injured by the worm, and ship-worms might perhaps have the same aversion to it as other worms have.

Other wood fit for the building of ships is very common in this country; such as elm, ash, alder, and others. There are likewise in this country several species of wood, which might sell in France for joiners work and fineering, as the cedar, the black walnut, and the cotton-tree. Nothing more would therefore be wanting for compleating ships but cordage and iron. As to hemp, it grows so strong as to be much fitter for making cables than cloth. The iron might be brought from France, as also sails; however, there needs only to open the iron mine at the cliffs of the Chicasaws, called Prud'homme, to set up forges, and iron will be readily had. The king, therefore, might cause all sorts of shipping to be built there at so small a charge, that a moderate expence would procure a numerous fleet. If the English build ships in their colonies 
from which they draw great advantages, why might not we do the same in Louisiana?

France fetches a great deal of saltpetre from Holland and Italy; she may draw from Louisiana more than she will have occasion for, if once she sets about it. The great fertility of the country is an evident proof thereof, confirmed by the avidity of cloven-footed animals to lick the earth, in all places where the torrents have broke it up: it is well known how fond these creatures are of salt. Saltpetre might be made there with all the ease imaginable, on account of the plenty of wood and water; it would besides be much more pure than what is commonly had, the earth not being fouled with dunghills; and on the other hand, it would not be dearer than what is now purchased by France in other places.

What commerce might not be made with Silk? The silkworms might be reared with much greater success in this country than in France, as appears from the trials that have been made, and which I have above related.

The lands of Louisiana are very proper for the culture of Saffron, and the climate would contribute to produce it in great abundance; and, what would still be a considerable advantage, the Spaniards of Mexico, who consume a great deal of it, would enhance its price.

I have spoken of Hemp, in respect to the building of ships: but such as might be built there, would never be sufficient to employ all the hemp which might be raised in that colony, did the inhabitants cultivate as much of it as they well might. But you will say, Why do they not? My answer is, the inhabitants of this colony only follow the beaten track they have got into: but if they saw an intelligent person sow hemp without any great expence or labour, as the soil is very fit for it; if, I say, they saw that it thrives without weeding; that in the winter evenings the negroes and their children can peel it; in a word, if they saw that there is good profit to be had by the sale of it; they then would all make hemp. They think and act in the same manner as to all the other articles of culture in this country. 
Cotton is also a good commodity for commerce; and the culture of it is attended with no difficulty. The only impediment to the culture of it in a greater quantity, is the difficulty of separating it from the seed. However, if they had mills, which would do this work with greater dispatch, the profit would considerably increase.

The Indigo of Louisiana, according to intelligent merchants, is as good as that of the islands; and has even more of the copper colour. As it thrives extremely well, and yields more herb than in the islands, as much Indigo may be made as there, though they have four cuttings, and only three in Louisiana. The climate is warmer in the islands, and therefore they make four gatherings; but the soil is drier, and produces not so much as Louisiana: so that the three cuttings of this last are as good as the four cuttings in the islands.

The Tobacco of this colony is so excellent, that if the commerce thereof was free, it would sell for one hundred sols and six livres the pound, so fine and delicate is its juice and flavour. Rice may also form a fine branch of trade. We go to the EastIndies for the rice we consume in France; and why should we draw from foreign countries, what we may have of our own countrymen? We should have it at less trouble, and with more security. Besides, as sometimes, perhaps too often, years of scarcity happen, we might always depend upon finding rice in Louisiana, because it is not subject to fail, an advantage which few provinces enjoy.

We may add to this commerce some drugs, used in medicine and dying. As to the first, Louisiana produces Sassafras, Sarsaparilla, Esquine, but above all the excellent balm of Copalm (Sweet-gum) the virtues of which, if well known, would save the life of many a person. This colony also furnishes us with bears oil, which is excellent in all rheumatic pains. For dying, I find only the wood Ayac, or Stinking Wood, for yellow; and the Achetchi for red; of the beauty of which colours we shall give an account in the third book.

Such are the commodities which may form a commerce of this colony with France, which last may carry in exchange all 
sorts of European goods and merchandize; the vent whereof is certain, as every thing answers there, where luxury reigns equally as in France. Flour, wines, and strong liquors sell well; and though I have spoken of the manner of growing wheat in this country, the inhabitants, towards the lower part of the river especially, will never grow it, any more than they will cultivate the vine, because in these sorts of work a negro will not earn his master half as much as in cultivating Tobacco; which, however, is less profitable than Indigo.

The Commerce of Louisiana with the Islands.

FROM Louisiana to the Islands they carry cypress wood squared for building, of different scantlings: sometimes they transport houses, all framed and marked out, ready to set up, on landing at their place of destination.

Bricks, which cost fourteen or fifteen livres the thousand, delivered on board the ship.

Tiles for covering houses and sheds, of the same price.

Apalachean beans, (Garavanzas) worth ten livres the barrel, of two hundred weight.

Maiz, or Indian corn.

Cypress plank of ten or twelve feet.

Red peas, which cost in the country twelve or thirteen livres the barrel.

Cleaned rice, which costs twenty livres the barrel, of two hundred weight.

There is a great profit to be made in the islands, by carrying thither the goods I have just mentioned: this profit is generally cent. per cent. in returns. The shipping which go from the colony bring back sugar, coffee, rum, which the negroes consume in drink; besides other goods for the use of the country.

The ships which come from France to Louisiana put all in at Cape François. Sometimes there are ships, which not having a lading for France, because they may have been paid in money or bills of exchange, are obliged to return by Cape François, in order to take in their cargo for France. 
ChAPTER XI.

Of the Commerce with the Spaniards. The Commodities they bring to the Colony, if there is a Demand for them. Of such as may be given in return, and may suit them. Reflections on the Commerce of this Province, and the great Advantage which the State and particular Persons may derive therefrom.

\section{The Commerce with the Spaniards.}

THE commodities which suit the Spaniards are sufficiently known by traders, and therefore it is not necessary to give an account of them: I have likewise forebore to give the particulars of the commodities which they carry to this colony, though I know them all: that is not our present business. I shall only apprise such as shall settle in Louisiana, in order to traffick with the Spaniards, that it is not sufficient to be furnished with the principal commodities which suit their commerce, but they should, besides, know how to make the proper assortments; which are most advantageous to us, as well as to them, when they carry them to Mexico.

The Commodities which the Spaniards bring to Louisiana, if there is a demand for them.

CAMPEACHY wood, which is generally worth from ten to fifteen livres the hundred weight.

Brasil wood, which has a quality superior to that of Campeachy.

Very good Cacoa, which is to be met with in all the ports of Spain, worth between eighteen and twenty livres the quintal, or hundred weight.

Cochineal, which comes from Vera Cruz: there is no difficulty to have as much of it as one can desire, because so near; it is worth fifteen livres the pound: there is an inferior sort, called Sylvester.

Tortoise-shell, which is common in the Spanish islands, is worth seven or eight livres the pound.

Tanned leather, of which they have great quantities; that marked or stamped is worth four livres ten sols the levee. 
Marroquin, or Spanish leather, of which they have great quantities, and cheap.

Turned calf, which is also cheap.

Indigo, which is manufactured at Guatimala, is worth three or four livres the pound: there is of it of a perfect good quality, and therefore sells at twelve livres the pound.

Sarsaparilla, which they have in very great quantities, and sell at thirteen or fifteen sols.

Havanna snuff, which is of different prices and qualities: I have seen it at three shillings the pound, which in our money make thirty-seven sols six deniers.

Vanilla, which is of different prices. They have many other things very cheap, on which great profits might be made, and for which an easy vent may be found in Europe; especially for their drugs: but a particular detail would carry me too far, and make me lose sight of the object I had in view.

What I have just said of the commerce of Louisiana, may easily shew that it will necessarily encrease in proportion as the country is peopled; and industry also will be brought to perfection. For this purpose nothing more is requisite than some inventive and industrious geniuses, who coming from Europe, may discover such objects of commerce as may turn to account. I imagine a good tanner might in this colony tan the leather of the country, and cheaper than in France; I even imagine that the leather might there be brought to its perfection in less time; and what makes me think so, is, that I have heard it averred, that the Spanish leather is extremely good, and is never above three or four months in the tan-pit.

The same will hold of many other things, which would prevent money going out of the kingdom to foreign countries. Would it not be more suitable and more useful, to devise means of drawing the same commodities from our own colonies? As these means are so easy, at least money would not go out of our hands; France and her colonies would be as two families who traffick together, and render each other mutual service. Besides, there would not be occasion for so much money to carry on a commerce to Louisiana, seeing the inhabitants have need of European goods. It would therefore be a commerce 
very different from that which, without exporting the merchandise of the kingdom, exports the money; a commerce still very different from that which carries to France commodities highly prejudicial to our own manufactures.

I may add to all that I have said on Louisiana, as one of the great advantages of this country, that women are very fruitful in it, which they attribute to the waters of the Missisippi. Had the intentions of the Company been pursued, and their orders executed, there is no doubt but this colony had at this day been very strong, and blessed with a numerous young progeny, whom no other climate would allure to go and settle in; but being retained by the beauty of their own, they would improve its riches, and multiplied anew in a short time, could offer their mother-country succours in men and ships, and in many other things that are not to be contemned.

I cannot too much shew the importance of the succours in corn, which this colony might furnish in a time of scarcity. In a bad year we are obliged to carry our money to foreigners for corn, which has been oftentimes purchased in France, because they have had the secret of preserving their corn; but if the colony of Louisiana was once well settled, what supplies of corn might not be received from that fruitful country? I shall give two reasons which will confirm my opinion.

The first is, That the inhabitants always grow more corn than is necessary for the subsistence of themselves, their workmen, and slaves. I own, that in the lower part of the colony only rice could be had, but this is always a great supply. Now, were the colony gradually settled to the Arkansas, they would grow wheat and rye in as great quantities as one could well desire, which would be of great service to France, when her crops happen to fail.

The second reason is, That in this colony a scarcity is never to be apprehended. On my arrival in it, I informed myself of what had happened therein from 1700, and I myself remained in it till 1734; and since my return to France I have had accounts from it down to this present year 1757; and from these accounts $I$ can aver, that no intemperature of season has caused 
any scarcity since the beginning of this century. I was witness to one of the severest winters that had been known in that country in the memory of the oldest people living; but provisions were then not dearer than in other years. The soil of this province being excellent, and the seasons always suitable, the provisions and other commodities cultivated in it never fail to thrive surprizingly.

One will, perhaps, be surprized to hear me promise such fine things of a country which has been reckoned to be so much inferior to the Spanish or Portuguese colonies in America; but such as will take the trouble to reflect on that which constitutes the genuine strength of states, and the real goodness of a country, will soon alter their opinion, and agree with me, that a country fertile in men, in productions of the earth, and in necessary metals, is infinitely preferable to countries from which men draw gold, silver, and diamonds: the first effect of which is to pamper luxury and render the people indolent; and the second to stir up the avarice of neighbouring nations. I therefore boldly aver, that Louisiana, well governed, would not long fail to fulfil all I have advanced about it; for though there are still some nations of Indians who might prove enemies to the French, the settlers, by their martial character, and their zeal for their king and country, aided by a few troops, commanded, above all, by good officers, who at the same time know how to command the colonists: the settlers, I say, will be always match enough for them, and prevent any foreigners whatever from invading the country. What would therefore be the consequence if, as I have projected, the first nation that should become our enemy were attacked in the manner I have laid down in my reflections on an Indian war? They would be directly brought to such a pass as to make all other nations tremble at the very name of the French, and to be ever cautious of making war upon them. Not to mention the advantage there is in carrying on wars in this manner; for as they cost little, as little do they hazard the loss of lives.

In 1734, M. Perier, Governor of Louisiana, was relieved by $M$. de Biainville, and the King's plantation put on a new footing, by an arrangement suitable to the notions of the per- 
son who advised it. A sycophant, who wanted to make his court to Cardinal Fleury, would persuade that minister, that the plantation cost his Majesty ten thousand livres a year, and that this sum might be well saved; but took care not to tell his Eminence, that for these ten thousand it saved at least fifty thousand livres.

Upon this, my place of Director of the public plantations was abolished, and I at length resolved to quit the colony and return to France, nothwithstanding all the fair promises and warm solicitations of my superiors to prevail upon me to stay. A King's ship, La Gironde, being ready to sail, I went down the river in her to Balise, and from thence we set sail, on the 10th of May, 1734. We had tolerable fine weather to the mouth of the Bahama Streights; afterwards we had the wind contrary, which retarded our voyage for a week about the banks of Newfoundland, to which we were obliged to stretch for a wind to carry us to France: from thence we made the passage without any cross accident, and happily arrived in the road of Chaidbois before Rochelle, on the 25th of June following, which made it a passage of forty-five days from Louisiana to France.

Some Abstracts from the Historical Memoirs of Louisiana, by M. Du Mont.

I.

Of Tobacco, with the way of cultivating and curing it.

THE Lands of Louisiana are as proper as could be desired, for the culture of tobacco; and, without despising what is made in other countries, we may affirm that the tobacco which grows in the country of the Natchez, is even preferable to that of Virginia or St. Domingo; I say, in the country of the Natchez, because the soil at that post appears to be more suitable to this plant than any other: although it must be owned, that there is but very little difference betwixt the tobacco which grows there and in some other parts of the colony, as at the Cut-point, at the Nachitoches, and even at New Orleans; but whether it is owing to the exposure, or to the goodness of 
the soil, it is allowed that the tobacco of the Natchez and Yasous is preferable to the rest.

The way of planting and curing tobacco in this country, is as follows: they sow it on beds well worked with the hoe or spade in the months of December, January, or February; and because the seed is very small, they mix it with ashes, that it may be thinner sowed: then they rake the beds, and trample them with their feet, or clap them with a plank, that the seed may take sooner in the ground. The tobacco does not come up till a month afterwards, or even for a longer time; and then they ought to take great care to cover the beds with straw or cypress-bark, to preserve the plants from the white frosts, that are very common in that season. There are two sorts of tobacco; the one with a long and sharp-pointed leaf, the other has a round and hairy leaf; which last they reckon the best sort.

At the end of April, and about St. George's day, the plants have about four leaves, and then they pull the best and strongest of them: these they plant out on their tobacco-ground by a line stretched across it, and at three feet distance one from another: this they do either with a planting-stick, or with their finger, leaving a hole on one side of the plant, to receive the water, with which they ought to water it. The tobacco being thus planted, it should be looked over evening and morning, in order to destroy a black worm, which eats the bud of the plant, and afterwards buries itself in the ground. If any of the plants are eat by this worm, you must set another one by it. You must choose a rainy season to plant your tobacco, and you should water it three times to make it take root. But they never work their ground in this country to plant their tobacco; they reckon it sufficient to stir it a little about four inches square round the plant.

When the tobacco is about four or five inches high, they weed it, and clean the ground all about it, and hill up every plant. They do the same again, when it is about a foot and a half high. And when the plant has about eight or nine leaves, and is ready to put forth a stalk, they nip off the top, which they call topping the tobacco: this amputation makes the 
leaves grow longer and thicker. After this, you must look over every plant, and every leaf, in order to sucker it, or to pull off the buds, which grow at the joints of the leaves; and at the same time you must destroy the large green worms that are found on the tobacco, which are often as large as a man's finger, and would eat up the whole plant in a night's time.

After this, you must take care to have ready a hanger (or tobacco-house,) which in Louisiana they make in the following manner: they set several posts in the ground, at equal distances from one another, and lay a beam or plate on the top of them, making thus the form of a house of an oblong square. In the middle of this square they set up two forks, about one third higher than the posts, and lay a pole cross them, for the ridgepole of the building; upon which they nail the rafters, and cover them with cypress-bark, or palmetto-leaves. The first settlers likewise build their dwelling-houses in this manner, which answer the purpose very well, and as well as the houses which their carpenters build for them, especially for the curing of tobacco; which they hang in these houses upon sticks or canes, laid across the building, and about four feet and a half asunder, one above another.

The tobacco-house being ready, you wait till your tobacco is ripe, and fit to be cut; which you may know by the leaves being brittle, and easily broke between the fingers, especially in the morning before sun-rising; but those versed in it know when the tobacco is fit to cut by the looks of it, and at first sight. You cut your tobacco with a knife as nigh the ground as you can, after which you lay it upon the ground for some time, that the leaves may fall, or grow tender, and not break in carrying. When you carry your tobacco to the house, you hang it first at the top by pairs, or two plants together, thus continuing from story to story, taking care that the plants thus hung are about two inches asunder, and that they do not touch one another, lest they should rot. In this manner they fill their whole house with tobacco, and leave it to sweat and dry.

After the tobacco is cut, they weed and clean the ground on which it grew: each root then puts out several suckers, which are all pulled off, and only one of the best is left to 
grow, of which the same care is taken as of the first crop. By this means a second crop is made on the same ground, and sometimes a third. These seconds, indeed, as they are called, do not usually grow so high as the first plant, but notwithstanding they make very good tobacco*.

If you have a mind to make your tobacco into rolls, there is no occasion to wait till the leaves are perfectly dry; but as soon as they have acquired a yellowish brown colour, although the stem is green, you unhang your tobacco, and strip the leaves from the stalks, lay them up in heaps, and cover them with woolen cloths, in order to sweat them. After that you stem the tobacco, or pull out the middle rib of the leaf, which you throw away with the stalks, as good for nothing; laying by the longest and largest of the leaves, that are of a good blackish brown colour, and keep them for a covering for your rolls. After this you take a piece of coarse linen, at least eight inches broad and a foot long, which you spread on the ground, and on it lay the large leaves you have picked out, and the others over them in handfuls, taking care always to have more in the middle than at the ends: then you roll the

* This is an advantage that they have in Louisiana over our tobacco planters, who are prohibited by law to cultivate these seconds; the summers are so short, that they do not come to due maturity in our tobacco colonies; whereas in Louisiana the summers are two or three months longer, by which they make two or three crops of tobacco a year upon the same ground, as early as we make one. Add to this, their fresh lands will produce three times as much of that commodity, as our old plantations; which are now worn out with culture, by supplying the whole world almost with tobacco for a hundred and fifty years. Now if their tobacco is worth five and six shillings a pound, as we are told above, or even the tenth part of it, when ours is worth but two pence or three pence, and they give a bounty upon ships going to the Missisippi, when our tobacco is loaded with a duty equal to seven times its prime cost; they may, with all these advantages, soon get this trade from us, the only one this nation has left entire to itself. These advantages enable the planters to give a much better price for servants and slaves, and thereby to engross the trade. It was by these means, that the French got the sugar trade from us, after the treaty of Utrecht, by being allowed to transport their people from St. Christopher's to the rich and fresh lands of St. Domingo; and by removing from Canada to Louisiana, they may in the like manner get not only this, but every other branch of the trade of North America. 
tobacco up in the cloth, tying it in the middle and at each end. When you have made a sufficient number of these bundles, the negroes roll them up as hard as they can with a cord about as big as the little finger, which is commonly about fifteen or sixteen fathom long: you tighten them three times, so as to make them as hard as possible; and to keep them so, you might tie them up with a string.

But since the time of the West India company, we have seldom cured our tobacco in this manner, if it is not for our own use; we now cure it in hands, or bundles of the leaves, which they pack in hogsheads, and deliver it thus in France to the farmers general. In order to cure the tobacco in this manner, they wait till the leaves of the stem are perfectly dry, and in moist, giving weather, they strip the leaves from the stalk, till they have a handful of them, called a hand, or bundle of tobacco, which they tie up with another leaf. These bundles they lay in heaps, in order to sweat them, for which purpose they cover those heaps with blankets, and lay boards or planks over them. But you should take care that the tobacco is not over-heated, and does not take fire, which may easily happen; for which purpose you uncover your heaps from time to time, and give the tobacco air, by spreading it abroad. This you continue to do till you find no more heat in the tobacco; then you pack it in hogsheads, and may transport it any where, without danger either of its heating or rotting.

II.

Of the way of making Indigo.

The blue stone, known by the name of Indigo, is the extract of a plant which they who have a sufficient number of slaves to manage it, make some quantities throughout all this colony. For this purpose they first weed the ground, and make small holes in it with a hoe, about five inches asunder, and on a straight line. In each of these holes they put five or six seeds of the indigo, which are small, long, and hard. When they come up, they put forth leaves somewhat like those of box, but a little longer and broader, and not so thick and indented. When the plant is five or six inches high, they take 
care to loosen the earth about the root, and at the same time to weed it. They reckon it has acquired a proper maturity, when it is about three feet and a half high: this you may likewise know, if the leaf cracks as you squeeze the plant in your hand.

Before you cut it, you get ready a place that is covered in the same manner with the one made for tobacco, about twentyfive feet high; in which you put three vats, one above another, as it were in different stories, so that the highest is the largest; that in the middle is square, and the deepest; the third, at bottom, is the least.

After these operations, you cut the indigo, and when you have several arms-full, or bundles of the plant, to the quantity judged necessary for one working, you fill the vat at least three quarters full; after which you pour water thereon up to the brim, and the plant is left to steep, in order to rot it; which is the reason why this vat is called the rotting-tub. For the three or four hours which the plant takes to rot, the water is impregnated with its virtue; and, though the plant is green, communicates thereto a blue colour.

At the bottom of the great vat, and where it bears on the one in the middle (which, as was said, is square) is a pretty large hole, stopped with a bung; which is opened when the plant is thought to be sufficiently rotten, and all the water of this vat, mixed with the mud, formed by the rotting of the plant, falls by this hole into the second vat; on the edges of which are placed, at proper distances, forks of iron or wood, on which large long poles are laid, which reach from the two sides to the middle of the water in the vat; the end plunged in the water is furnished with a bucket without a bottom. A number of slaves lay hold on these poles, by the end which is out of the water; and alternately pulling them down, and then letting the buckets fall into the vat, they thus continue to beat the water; which being thus agitated and churned, comes to be covered with a white and thick scum; and in such quantity as that it would rise up and flow over the brim of the vat, if the operator did not take care to throw in, from time to time, some fish-oil, which he sprinkles with a feather upon this scum. For these reasons this vat is called the battery. 
They continue to beat the water for an hour and a half, or two hours; after which they give over, and the water is left to settle. However, they from time to time open three holes, which are placed at proper distances from top to bottom in one of the sides of this second vat, in order to let the water run off clear. This is repeated for three several times; but when at the third time the muddy water is ready to come out at the lowermost hole, they stop it, and open another pierced in the lower part of that side, which rests on the third vat. Then all the muddy water falls through that hole of the second vat into the third, which is the least, and is called the deviling (diablotin.)

They have sacks, a foot long, made of a pretty close cloth, which they fill with this liquid thick matter, and hang them on nails round the indigo-house. The water drains out gradually; and the matter which is left behind, resembles a real mud, which they take out of these sacks, and put in moulds, made like little drawers, two feet long by half a foot broad, and with a border, or ledge, an inch and a half high. Then they lay them out in the sun, which draws off all the moisture: and as this mud comes to dry, care is taken to work it with a mason's trowel: at length it forms a body, which holds together, and is cut in pieces, while fresh, with wire. It is in this manner that they draw from a green herb this fine blue colour, of which there are two sorts, one of which is of a purple dove colour.

\section{III.}

Of Tar; the way of making it; and of making it into Pitch.

I have said, that they made a great deal of tar in this colony, from pines and firs; which is done in the following manner. It is a common mistake, that tar is nothing but the sap or gum of the pine, drawn from the tree by incision; the largest trees would not yield two pounds by this method; and if it were to be made in that manner, you must choose the most thriving and flourishing trees for the purpose; whereas it is only made from the trees that are old, and are beginning to decay, because the older they are, the greater quantities they contain of that fat bituminous substance, which yields tar; it 
is even proper that the tree should be felled a long time, before they use them for this purpose. It is usually towards the mouth of the river, and along the sea-coasts, that they make tar; because it is in those places that the pines chiefly grow.

When they have a sufficient number of these trees, that are fit for the purpose, they saw them in cuts with a cross-cut saw, about two feet in length; and while the slaves are employed in sawing them, others split these cuts lengthwise into small pieces, the smaller the better. They sometimes spend three or four months in cutting and preparing the trees in this manner. In the mean time they make a square hollow in the ground, four or five feet broad, and five or six inches deep: from one side of which goes off a canal or gutter, which discharges itself into a large and pretty deep pit, at the distance of a few paces. From this pit proceeds another canal, which communicates with a second pit; and even from the first square you make three or four such trenches, which discharge themselves into as many pits, according to the quantity of wood you have, or the quantity of tar you imagine you may draw from it. Then you lay over the square hole four or five pretty strong bars of iron, and upon these bars you arrange crosswise the split pieces of pine, of which you should have a quantity ready; laying them so, that there may be a little air between them. In this manner you raise a large and high pyramid of the wood, and when it is finished, you set fire to it at the top. As the wood burns, the fire melts the resin in the pine, and this liquid tar distills into the square hole, and from thence runs into the pits made to receive it.

If you would make pitch of this tar, take two or three red-hot cannon bullets, and throw them into the pits, full of the tar, which you intend for this purpose: immediately upon which, the tar takes fire with a terrible noise and a horrible thick smoke, by which the moisture that may remain in the tar is consumed and dissipated, and the mass diminishes in proportion; and when they think it is sufficiently burnt, they extinguish the fire, not with water, but with a hurdle covered with turf and earth. As it grows cold, it becomes hard and shining, so that you cannot take it out of the pits, but by cutting it with an axe. 
IV.

Of the Mines of Louisiana.

BEFORE we quit this subject, I shall conclude this account by answering a question, which has often been proposed to me. Are there any Mines, say they, in this province? There are, without all dispute; and that is so certain, and so well known, that they who have any knowledge of this country never once called it in question. And it is allowed by all, that there are to be found in this country quarries of plaster of Paris, slate, and very fine veined marble; and I have learned from one of my friends, who as well as myself had been a great way on discoveries, that in travelling this province he had found a place full of fine stones of rock-crystal. As for my share, I can affirm, without endeavoring to impose on any one, that in one of my excursions I found, upon the river of the Arkansas, a rivulet that rolled down with its waters gold-dust; from which there is reason to believe that there are mines of this metal in that country. And as for silver-mines, there is no doubt but they might be found there, as well as in New Mexico, on which this province borders. A Canadian traveller, named Bon Homme, as he was hunting at some distance from the Post of the Nachitoches, melted some parcels of a mine, that is found in rocks at a very little distance from that Post, which appeared to be very good silver, without any farther purification*.

It will be objected to me, perhaps, that if there is any truth in what I advance, I should have come from that country laden with silver and gold; and that if these precious metals are to be found there, as I have said, it is surprizing that the French have never thought of discovering and digging them in thirty years, in which they have been settled in Louisiana. To this I answer, that this objection is only founded on the ignorance of those who make it; and that a traveller, or an officer, ordered by his superiors to go to reconnoitre the country, to draw plans, and give an account of what he has seen, in nothing but immense woods and deserts, where they cannot so

* See a farther account and assay of this mine above. 
much as find a path, but what is made by the wild beasts; I say, that such people have enough to do to take care of themselves and of their present business, instead of gathering riches; and think it sufficient, that they return in a whole skin.

With regard to the negligence that the French seem hitherto to have shewn in searching for these mines, and in digging them, we ought to take due notice, that in order to open a silver-mine, for example, you must advance at least a hundred thousand crowns, before you can expect to get a penny of profit from it, and that the people of the country are not in a condition to be at any such charge. Add to this, that the inhabitants are too ignorant of these mines; the Spaniards, their neighbours, are too discreet to teach them; and the French in Europe are too backward and timorous to engage in such an undertaking. But notwithstanding, it is certain that the thing has been already done, and that just reasons, without doubt, but different from an impossibility, have caused it to be laid aside.

This author gives a like account of the culture of Rice in Louisiana, and of all the other staple commodities of our colonies in North America. 
Extract from a late French Writer, concerning the Importance of Louisiana to France.

${ }^{66} \mathrm{O}^{\mathrm{NE}}$ cannot help lamenting the lethargic state of that colony, (Louisiana) which carries in its bosom the bed of the greatest riches; and in order to produce them, asks only arms proper for tilling the earth, which is wholly disposed to yield an hundred fold. Thanks to the fertility of our islands, our Sugar plantations are infinitely superior to those of the English, and we likewise excel them in our productions of Indigo, Coffee, and Cotton.

"Tobacco is the only production of the earth which gives the English an advantage over us. Providence, which reserved for us the discovery of Louisiana, has given us the possession of it, that we may be their rivals in this particular, or at least that we may be able to do without their Tobacco. Ought we to continue tributaries to them in this respect, when we can so easily do without them?

"I cannot help remarking here, that among several projects presented of late years for giving new force to this colony, a company of creditable merchants proposed to furnish negroes to the inhabitants, and to be paid for them in Tobacco alone at a fixed valuation.

"The following advantages, they demonstrated, would attend their scheme. I. It would increase a branch of commerce in France, which affords subsistence to two of the English colonies in America, namely Virginia and Maryland, the inhabitants of which consume annually a very considerable quantity of English stuffs, and employ a great number of ships in the transportation of their Tobacco. The inhabitants of those two provinces are so greatly multiplied, in consequence of the riches they have acquired by their commerce with us, that they begin to spread themselves upon territories that belong to us. II. The second advantage arising from the scheme would be, to carry the cultivation of Tobacco to its greatest extent and perfection. III. To diminish in proportion the cultivation of the English plantations, as well as lessen their navigation in that part. IV. To put an end entirely to the 
importation of any Tobacco from Great-Britain into France, in the space of twelve years. V. To diminish annually, and in the same space of time finally put an end to, the exportation of specie from France to Great-Britain, which amounts annually to five millions of our money for the purchase of Tobacco, and the freightage of English ships, which bring it into our ports. VI. By diminishing the cause of the outgoing specie, to augment the balance of commerce in favour of the nation. These are the principal advantages which France would have reason to have expected from the establishment of this company, if it had been effected." Essai sur les Interêts du Commerce Maritime, par M. du Haye. 1754.

The probability of succeeding in such a scheme will appear from the foregoing accounts of Tobacco in Louisiana, pag. 172, $173,181,188$, \&c. They only want hands to make any quantities of Tobacco in Louisiana. The consequences of that will appear from the following account. 
An Account of the Quantity of Tobacco imported into Britain, and exported from it, in the four Years of Peace, after the late Tobacco-Law took place, according to the Custom-House Accounts.

$$
\begin{aligned}
& \text { Imported Exported }
\end{aligned}
$$

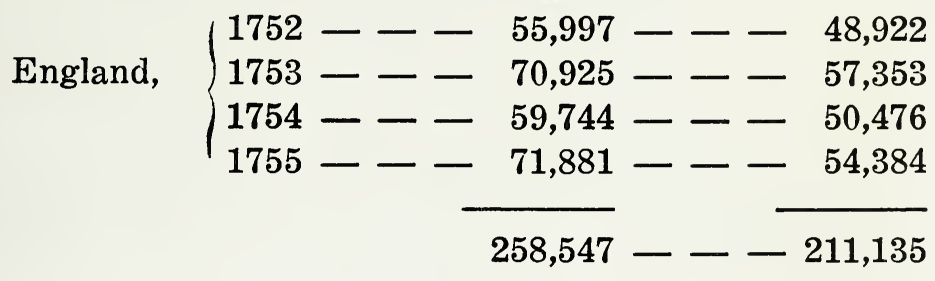

$$
\begin{aligned}
& 1752--\overline{22,322}--\overline{21,642} \\
& \text { Scotland, } \quad \begin{array}{l}
1753---26,210--22,728 \\
1754--2,334---21,764
\end{array} \\
& 1755 \text { - - 20,698 - - 19,711 } \\
& \overline{91,564}--\overline{87,845} \\
& \text { Total }--\overline{350,111}--\overline{298,980} \\
& \text { Average - - }-87,528-1-74,745 \\
& \text { Imported yearly }-\ldots \ldots \text { - }- \text { hhds } 87,528
\end{aligned}
$$$$
\text { Exported - - - - - - 74,745 }
$$

Home consumption - - - $-\overline{12,783}$

To 87,528 hogsheads, at $10 £$. per hogshead, - $-£ 875,280$ To duty on 12,783 hogsheads at $20 £$. - - - - 255,660

Annual income from Tobacco - - - - - 1,130,940

The number of seamen employed in the Tobacco trade is computed at 4500 ; -in the Sugar trade 3600 ; - and in the Fishery of Newfoundland 4000, from Britain. 



\section{THE \\ HIS T O R Y \\ OF \\ L O UISIA N A}

BOOK III.

The Natural History of LouIsIaNA.

\section{Chapter I. \\ Of Corn and Pulse.}

HAVING, in the former part of this work, given an account of the nature of the soil of Louisiana, and observed that some places were proper for one kind of plants, and some for another; and that almost the whole country was capable of producing, and bringing to the utmost maturity, all kinds of grain, I shall now present the industrious planter with an account of the trees and plants which may be cultivated to advantage in those lands with which he is now made acquainted.

During my abode in that country, where I myself have a grant of lands, and where I lived sixteen years, I have had leisure to study this subject, and have made such progress in it, that I have sent to the West-India Company in France no less than three hundred medicinal plants, found in their possessions, and worthy of the attention of the public. The reader may depend upon my being faithful and exact; he must not however here expect a description of every thing that Louisiana produces of the vegetable kind. Its prodigious fertility makes it impracticable for me to undertake so extensive a work. I shall chiefly describe those plants and fruits that are most useful to the inhabitants, either in regard to their own subsistence or preservation, or in regard to their foreign com- 
merce; and I shall add the manner of cultivating and managing the plants that are of greatest advantage to the colony.

Louisiana produces several kinds of Maiz, namely Flourmaiz, which is white, with a flat and shrivelled surface, and is the softest of all the kinds; Homony corn, which is round, hard, and shining; of this there are four sorts, the white, the yellow. the red, and the blue; the Maiz of these two last colours is more common in the high lands than in the Lower Louisiana. We have besides small corn, or small Maiz, so called because it is smaller than the other kinds. New settlers sow this corn upon their first arrival, in order to have whereon to subsist as soon as possible; for it rises very fast, and ripens in so short a time, that from the same field they may have two crops of it in one year. Besides this, it has the advantage of being more agreeable to the taste than the large kind.

Maiz, which in France is called Turkey Corn, (and in England Indian Corn) is the natural product of this country; for upon our arrival we found it cultivated by the natives. It grows upon a stalk six, seven, and eight feet high; the ear is large, and about two inches diameter, containing sometimes seven hundred grains and upwards; and each stalk bears sometimes six or seven ears, according to the goodness of the ground. The black and light soil is that which agrees best with it; but strong ground is not so favourable to it.

This corn, it is well known, is very wholesome both for man and other animals, especially for poultry. The natives, that they may have change of dishes, dress it in various ways. The best is to make it into what is called Parched Meal, (Farine Froide.) As there is nobody who does not eat of this with pleasure, even though not very hungry, I will give the manner of preparing it, that our provinces of France, which reap this grain, may draw the same advantage from it.

The corn is first parboiled in water; then drained and well dried. When it is perfectly dry, it is then roasted in a plate made for that purpose, ashes being mixed with it to hinder it from burning; and they keep continually stirring it, that it may take only the red colour which they want. When it has taken that colour, they remove the ashes, rub it well, and then 
put it in a mortar with the ashes of dried stalks of kidney beans, and a little water; they then beat it gently, which quickly breaks the husk, and turns the whole into meal. This meal, after being pounded, is dried in the sun, and after this last operation it may be carried any where, and will keep six months, if care be taken from time to time to expose it to the sun. When they want to eat of it, they mix in a vessel two thirds water with one third meal, and in a few minutes the mixture swells greatly in bulk, and is fit to eat. It is a very nourishing food, and is an excellent provision for travellers, and those who go to any distance to trade.

This parched meal, mixed with milk and a little sugar, may be served up at the best tables. When mixed with milkchocolate it makes a very lasting nourishment. From Maiz they make a strong and agreeable beer; and they likewise distil brandy from it.

Wheat, rye, barley, and oats grow extremely well in Louisiana; but I must add one precaution in regard to wheat; when it is sown by itself, as in France, it grows at first wonderfully; but when it is in flower, a great number of drops of red water may be observed at the bottom of the stalk within six inches of the ground, which are collected there during the night, and disappear at sun-rising. This water is of such an acrid nature, that in a short time it consumes the stalk, and the ear falls before the grain is formed. To prevent this misfortune, which is owing to the too great richness of the soil, the method I have taken, and which has succeeded extremely well, is to mix with the wheat you intend to sow, some rye and dry mould, in such a proportion that the mould shall be equal to the rye and wheat together. This method I remember to have seen practised in France; and when I asked the reason of it, the farmer told me that as the land was new, and had lately been a wood, it contained an acid that was prejudicial to the wheat; and that as the rye absorbed that acid without being hurt, it thereby preserved the other grain. I have seen barley and oats in that country three feet high.

The rice which is cultivated in that country was brought from Carolina. It succeeds surprizingly well, and experience 
has there proved, contrary to the common notion, that it does not want to have its foot always in the water. It has been sown in the flat country without being flooded, and the grain that was reaped was full grown, and of a very delicate taste. The fine relish need not surprise us; for it is so with all plants and fruits that grow without being watered, and at a distance from watery places. Two crops may be reaped from the same plant; but the second is poor if it be not flooded. I know not whether they have attempted, since I left Louisiana, to sow it upon the sides of hills.

The first settlers found in the country French-beans of various colours, particularly red and black, and they have been called beans of forty days, because they require no longer time to grow and to be fit to eat green. The Apalachean beans are so called because we received them from a nation of the natives of that name. They probably had them from the English of Carolina, whither they had been brought from Guinea. Their stalks spread upon the ground to the length of four or five feet. They are like the other beans, but much smaller, and of a brown colour, having a black ring round the eye, by which they are joined to the shell. These beans boil tender, and have a tolerable relish, but they are sweetish, and somewhat insipid.

The potatoes are roots more commonly long than thick; their form is various, and their fine skin is like that of the Topinambous (Irish potatoes.) In their substance and taste they very much resemble sweet chesnuts. They are cultivated in the following manner; the earth is raised in little hills or high furrows about a foot and a half broad, that by draining the moisture, the roots may have a better relish. The small potatoes being cut in little pieces with an eye in each, four or five of those pieces are planted on the head of the hills. In a short time they push out shoots, and these shoots being cut off about the middle of August within seven or eight inches of the ground, are planted double, cross-ways, in the crown of other hills. The roots of these last are the most esteemed, not only on account of their fine relish, but because they are easier kept during the winter. In order to preserve them during 


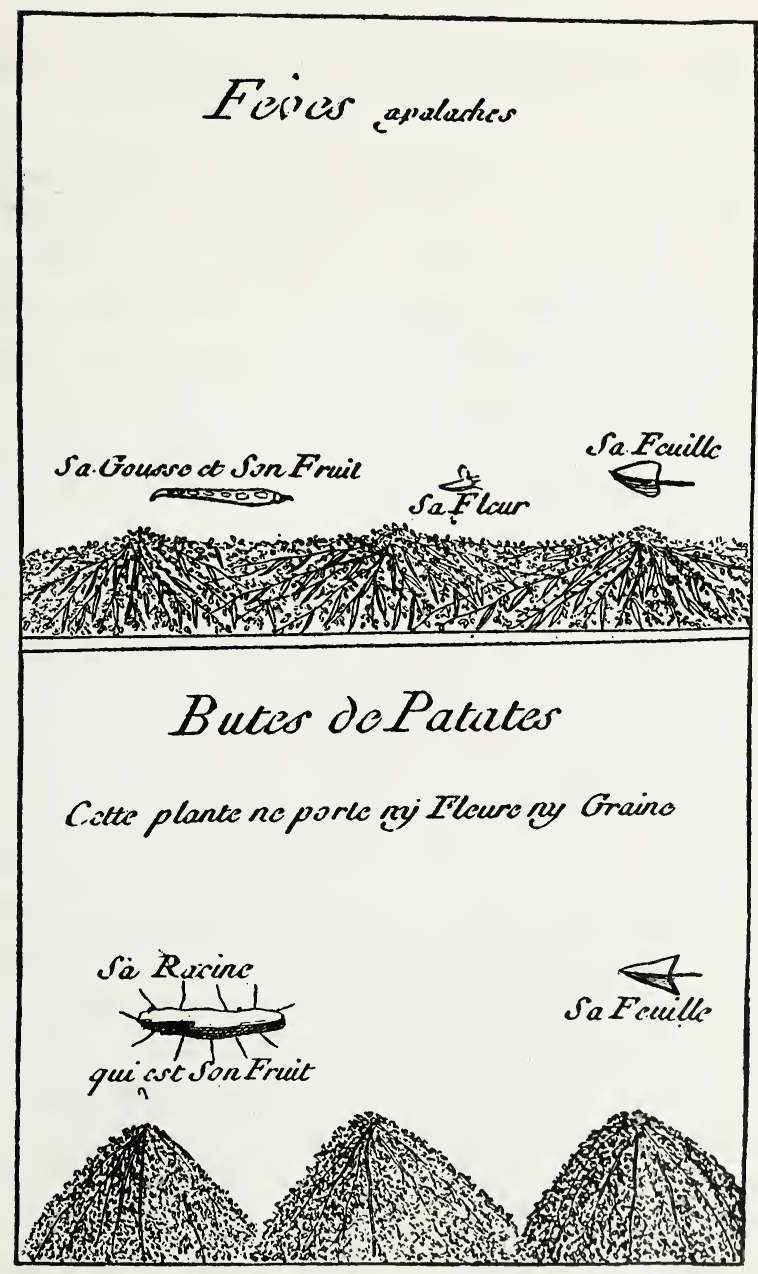

Top: Appalachean Beans-Bоттом: Sweet Potatoes

that season, they dry them in the sun as soon as they are dug up, and then lay them up in a close and dry place, covering them first with ashes, over which they lay dry mould. They boil them, or bake them, or roast them on hot coals like chesnuts; but they have the finest relish when baked or roasted. They are eat dry, or cut into small slices in milk without sugar, for they are sweet of themselves. Good sweetmeats are also 
made of them, and some Frenchmen have drawn brandy from them.

The Cushaws are a kind of pompion. There are two sorts of them, the one round, and the other in the shape of a hunting horn. These last are the best, being of a more firm substance, which makes them keep much better than the others; their sweetness is not so insipid, and they have rewer seeds. They make sweetmeats of these last, and use both kinds in soup; they make fritters of them, fry them, bake them, and roast them on the coals, and in all ways of cooking they are good and palatable.

All kinds of melons grow admirably well in Louisiana. Those of Spain, of France, of England, which last are called white melons, are there infinitely finer than in the countries from whence they have their name; but the best of all are the water melons. As they are hardly known in France, except in Provence, where a few of the small kind grow, I fancy a description of them will not be disagreeable to the reader.

The stalk of this melon spreads like ours upon the ground, and extends to the length of ten feet. It is so tender, that when it is any way bruised by treading upon it, the fruit dies; and if it is rubbed in the least, it grows warm. The leaves are very much indented, as broad as the hand when they are spread out, and are somewhat of a sea-green colour. The fruit is either round like a pompion, or long. There are some good melons of this last kind, but the first sort are most esteemed, and deservedly so. The weight of the largest rarely exceeds thirty pounds, but that of the smallest is always above ten pounds. Their rind is of a pale green colour, interspersed with large white spots. The substance that adheres to the rind is white, crude, and of a disagreeable tartness, and is therefore never eaten. The space within that is filled with a light and sparkling substance, that may be called for its properties a rose-coloured snow. It melts in the mouth as if it were actually snow, and leaves a relish like that of the water prepared for sick people from gooseberry jelly. This fruit cannot fail therefore of being very refreshing, and is so wholesome, that persons in all kinds of distempers may satisfy their 
Melon d'cau
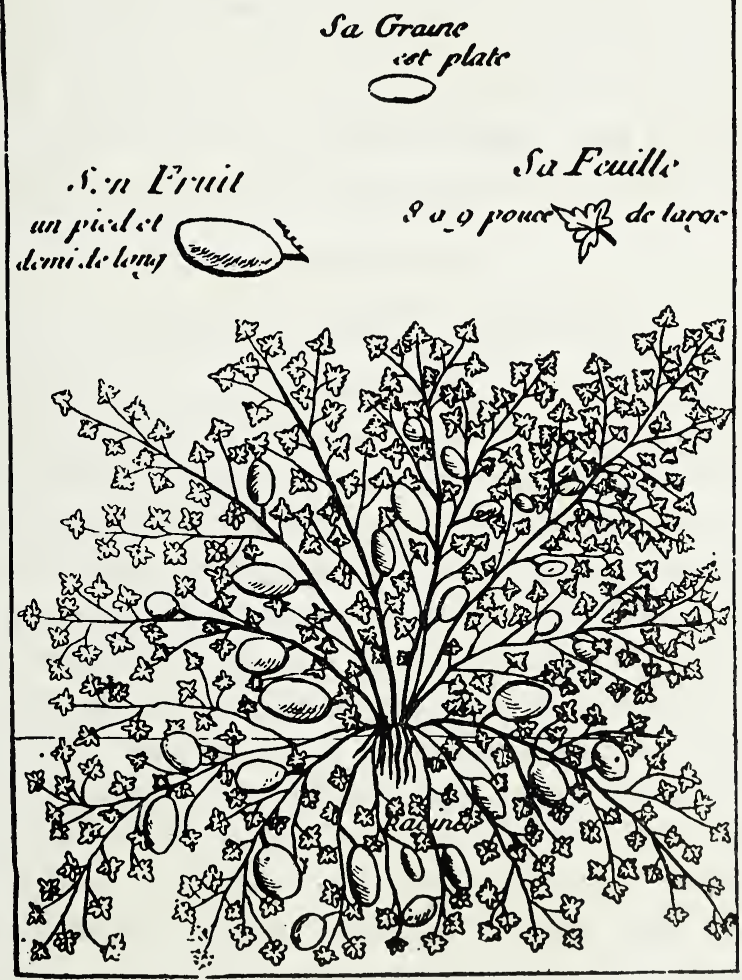

Watermelon

appetite with it, without any apprehension of being the worse for it. The water-melons of Africa are not near so relishing as those of Louisiana.

The seeds of water-melons are placed like those of the French melons. Their shape is oval and flat, being as thick at the ends as towards the middle; their length is about six lines, and their breadth four. Some are black and others red; but the black are the best, and it is those you ought to choose 
for sowing, if you would wish to have good fruit; which you cannot fail of, if they are not planted in strong ground, where they would degenerate and become red.

All kinds of greens and roots which have been brought from Europe into that colony succeed better there than in France, provided they be planted in a soil suited to them; for it is certainly absurd to think that onions and other bulbous plants should thrive there in a soft and watery soil, when every where else they require a light and dry earth.

\section{CHAPTER II. \\ Of the Fruit Trees of Louisiana.}

I Shall now proceed to give an account of the fruit trees of this colony, and shall begin with the Vine, which is so common in Louisiana, that whatever way you walk from the sea coast for five hundred leagues northwards, you cannot proceed an hundred steps without meeting with one; but unless the vine-shoots should happen to grow in an exposed place, it cannot be expected that their fruit should ever come to perfect maturity. The trees to which they twine are so high, and so thick of leaves, and the intervals of underwood are so filled with reeds, that the sun cannot warm the earth, or ripen the fruit of this shrub. I will not undertake to describe all the kinds of grapes which this country produces; it is even impossible to know them all; I shall only speak of three or four.

The first sort that I shall mention does not perhaps deserve the name of a grape, although its wood and its leaf greatly resemble the vine. This shrub bears no bunches, and you hardly ever see upon it above two grapes together. The grape in substance and colour is very like a violet damask plum, and its stone, which is always single, greatly resembles a nut. Though not very relishing, it has not however that disagreeable sharpness of the grape that grows in the neighbourhood of New Orleans.

On the edge of the savannahs or meadows we meet with a grape, the shoots of which resemble those of the Burgundy 
grape. They make from this a tolerable good wine, if they take care to expose it to the sun in summer, and to the cold in winter. I have made this experiment myself, and must say that I never could turn it into vinegar.

There is another kind of grape which I make no difficulty of classing with the grapes of Corinth, commonly called currants. It resembles them in the wood, the leaf, the tree, the size, and the sweetness. Its tartness is owing to its being prevented from ripening by the thick shade of the large trees to which it twines. If it were planted and cultivated in an ope? field, I make not the least doubt but it would equal the grape of Corinth, with which I class it.

Muscadine grapes, of an amber colour, of a very good kind, and very sweet, have been found upon declivities of a good exposure, even so far north as the latitude of 31 degrees. There is the greatest probability that they might make excellent wine of these, as it cannot be doubted but the grapes might be brought to great perfection in this country, since in the moist soil of New Orleans, the cuttings of the grape which some of the inhabitants of that city brought from France, have succeeded extremely well, and afforded good wine.

As a proof of the fertility of Louisiana, I cannot forbear mentioning the following fact; an inhabitant of New Orleans having planted in his garden a few twigs of this Muscadine vine, with a view of making an arbour of them, one of his sons, with another negro boy, entered the garden in the month of June, when the grapes are ripe, and broke off all the bunches they could find. The father, after severely chiding the two boys, pruned the twigs that had been broken and bruised; and as several months of summer still remained, the vine pushed out new shoots, and new bunches, which ripened and were as good as the former.

The Persimmon, which the French of the colony call Placminier, very much resembles our medlar-tree in its leaf and wood: its flower, which is about an inch and a half broad, is white, and is composed of five petals; its fruit is about the size of a large hen's egg; it is shaped like our medlar, but its substance is sweeter and more delicate. This fruit is astrin- 
gent; when it is quite ripe the natives make bread of it, which they keep from year to year; and the bread has this remarkable property that it will stop the most violent looseness or dysentery; therefore it ought to be used with caution, and only after physic. The natives, in order to make this bread, squeeze the fruit over fine sieves to separate the pulp from the skin and the kernels. Of this pulp, which is like paste or thick pap, they make cakes about a foot and a half long, a foot broad, and a finger's breadth in thickness: these they dry in an oven, upon gridirons, or else in the sun; which last method of drying gives a greater relish to the bread. This is one of their articles of traffick with the French.

Their plum-trees are of two sorts: the best is that which bears violet-coloured plums, quite like ours, which are not disagreeable, and which certainly would be good if they did not grow in the middle of woods. The other kind bears plums of the colour of an unripe cherry, and these are so tart that no body can eat them; but I am of opinion they might be preserved like gooseberries; especially if pains were taken to cultivate them in open grounds. The small cherries, called the Indian cherry, are frequent in this country. Their wood is very beautiful, and their leaves differ in nothing from those of the cherry tree.

The Papaws are only to be found far up in Higher Louisiana. These trees, it would seem, do not love heat; they do not grow so tall as the plum-trees; their wood is very hard and flexible; for the lower branches are sometimes so loaded with fruit that they hang perpendicularly downwards; and if you unload them of their fruit in the evening, you will find them next morning in their natural erect position. The fruit resembles a middle-sized cucumber; the pulp is very agreeable and very wholesome; but the rind, which is easily stripped off, leaves on the fingers so sharp an acid, that if you touch your eye with them before you wash them, it will be immediately inflamed, and itch most insupportably for twenty-four hours after.

The natives had doubtless got the peach-trees and figtrees from the English colony of Carolina, before the French 


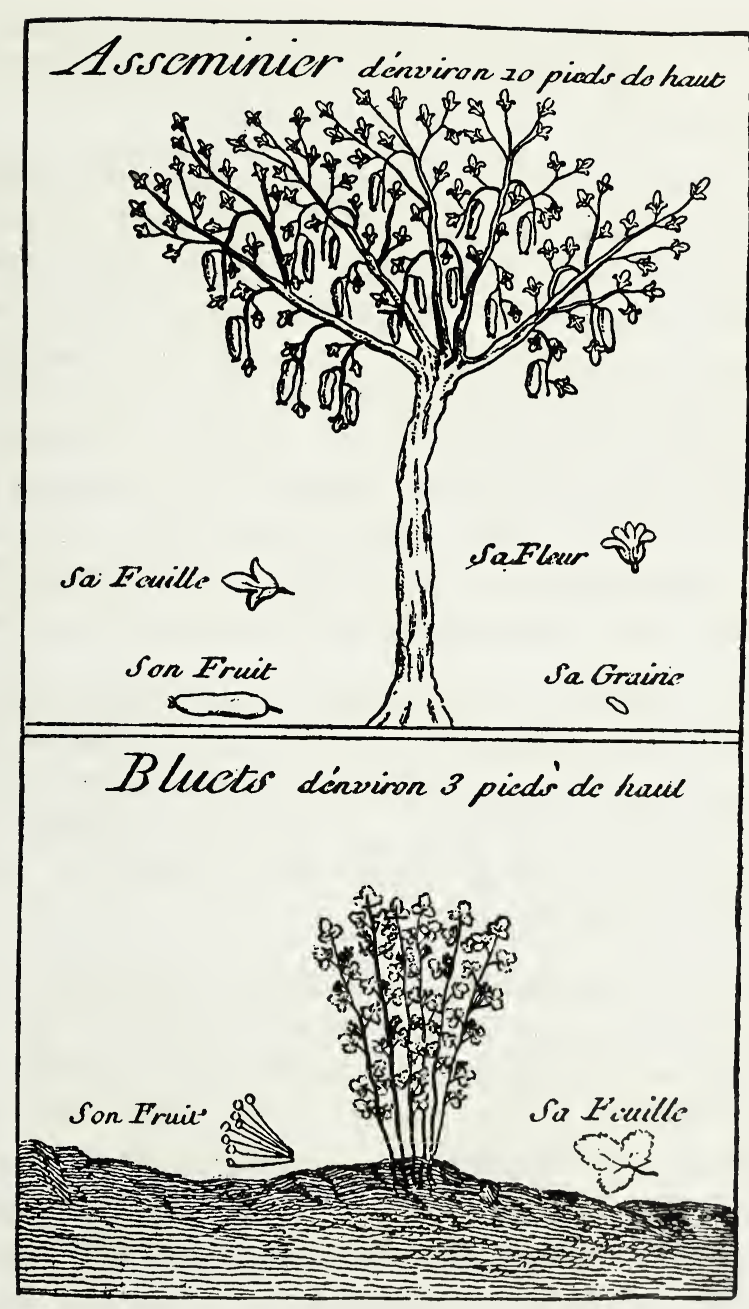

Tор: P.awpaw-Воттом: Blue Whortle-berry

established themselves in Louisiana. The peaches are of the kind which we call Alberges; are of the size of the fist, adhere to the stone, and contain so much water that they make a kind of wine of it. The figs are either blue or white; are large and well enough tasted. Our colonists plant the peach stones about the end of February, and suffer the trees to grow exposed to all weathers. In the third year they will gather from one tree at least two hundred peaches, and double that number for six 
or seven years more, when the tree dies irrecoverably. As new trees are so easily produced, the loss of the old ones is not in the least regretted.

The orange-trees and citron-trees that were brought from Cape François have succeeded extremely well; however I have seen so severe a winter that those kinds of trees were entirely frozen to the very trunk. In that case they cut the trees down to the ground, and the following summer they produced shoots that were better than the former. If these trees have succeeded in the flat and moist soil of New Orleans, what may we not expect when they are planted in better soil, and upon declivities of a good exposure? The oranges and citrons are as good as those of other countries; but the rind of the orange in particular is very thick, which makes it the better for a sweet-meat.

There is plenty of wild apples in Louisiana, like those in Europe; and the inhabitants have got many kind of fruit trees from France, such as apples, pears, plums, cherries, \&c. which in the low grounds run more into wood than fruit; the few I had at the Natches proved that high ground is much more suited to them than the low.

The blue Whortle-berry is a shrub somewhat taller than our largest gooseberry bushes, which are left to grow as they please. Its berries are of the shape of a gooseberry, grow single, and are of a blue colour: they taste like a sweetish gooseberry, and when infused in brandy it makes a good dram. They attribute several virtues to it, which, as I never experienced, I cannot answer for. It loves a poor gravelly soil.

Louisiana produces no black mulberries: but from the sea to the Arkansas, which is an extent of navigation upon the river of two hundred leagues, we meet very frequently with three kinds of mulberries; one a bright red, another perfectly white, and a third white and sweetish. The first of these kinds is very common, but the two last are more rare. Of the red mulberries they make excellent vinegar, which keeps a long time, provided they take care in the making of it to keep it in the shade in a vessel well stopped, contrary to the practice in France. They make vinegar also of bramble berries, but this 
is not so good as the former. I do not doubt but the colonists at present apply themselves seriously to the cultivation of mulberries, to feed silk-worms, especially as the countries adjoining to France, and which supplied us with silk, have now made the exportation of it difficult.

The olive-trees in this colony are surprisingly beautiful. The trunk is sometimes a foot and a half diameter, and thirty feet high before it spreads out into branches. The Provençals settled in the colony affirm, that its olives would afford as good an oil as those of their country. Some of the olives that were prepared to be eat green, were as good as those of Provence. I have reason to think, that if they were planted on the coasts, the olives would have a finer relish.

They have great numbers and a variety of kinds of walnut-trees in this country. There is a very large kind, the wood of which is almost as black as ebony, but very porous. The fruit, with the outer shell, is of the size of a large hen's egg: the shell has no cleft, is very rough and so hard as to require a hammer to break it. Though the fruit be very relishing, yet it is covered with such a thick film, that few can bestow the pains of separating the one from the other. The natives make bread of it, by throwing the fruit into water, and rubbing it till the film and oil be separated from it. If those trees were engrafted with the French walnut, their fruit would probably be improved.

Other walnut-trees have a very white and flexible wood. Of this wood the natives make their crooked spades for hoeing their fields. The nut is smaller than ours, and the shell more tender; but the fruit is so bitter that none but perroquets can put up with it.

The Hicori bears a very small kind of nut, which at first sight one would take for filberts, as they have the same shape and colour, and their shell is as tender, but within they are formed like walnuts. They have such an excellent relish, that the French make fried cakes of them as good as those of almonds.

Louisiana produces but a few filberts, as the filbert requires a poor gravelly soil which is not to be met with in this 


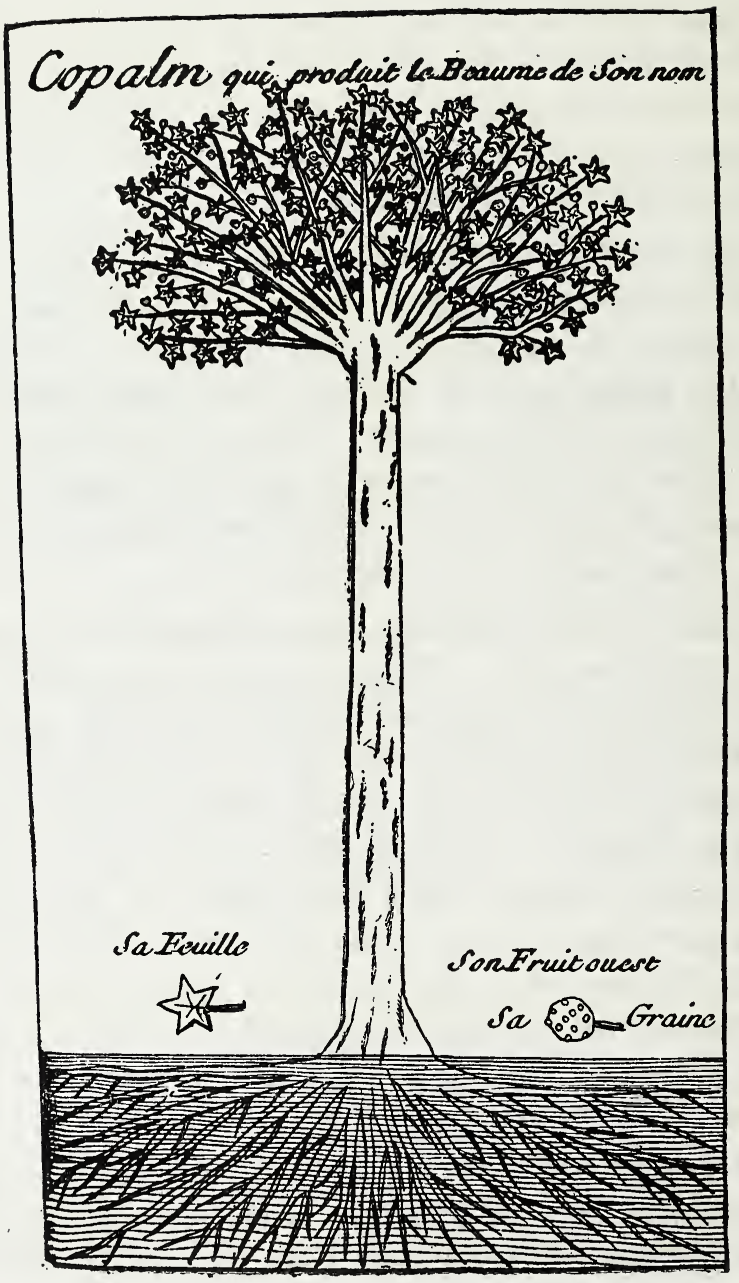

Sweet Gum or Liquid-Amber

province, except in the neighbourhood of the sea, especially near the river Mobile.

The large chesnuts are not to be met with but at the distance of one hundred leagues from the sea, and far from rivers in the heart of the woods, between the country of the Chactaws and that of the Chicasaws. The common chesnuts succeed best upon high declivities, and their fruit is like the chesnuts that grow in our woods. There is another kind of chesnuts, which are called the Acorn chesnuts, as they are shaped like an acorn, 
and grow in such a cup. But they have the colour and taste of a chesnut; and I have often thought that those were the acorns which the first of men were said to have lived upon.

The Sweet-Gum, or Liquid-Ambar (Copalm) is not only extremely common, but it affords a balm, the virtues of which are infinite. Its bark is black and hard, and its wood so tender and supple, that when the tree is felled you may draw from the middle of it rods of five or six feet in length. It cannot be employed in building or furniture, as it warps continually; nor is it fit for burning on account of its strong smell; but a little of it in a fire yields an agreeable perfume. Its leaf is indented with five points like a star.

I shall not undertake to particularize all the virtues of this Sweet-Gum or Liquid-Ambar, not having learned all of them from the natives of the country, who would be no less surprised to find that we used it only as a varnish, than they were to see our surgeons bleed their patients. This balm, according to them, is an excellent febrifuge; they take ten or a dozen drops of it in gruel fasting, and before their meals; and if they should take a little more, they have no reason to apprehend any danger. The physicians among the natives purge their patients before they give it them. It cures wounds in two days without any bad consequences: it is equally sovereign for all kinds of ulcers, after having applied to them for some days a plaster of bruisec: ground-ivy. It cures consumptions, opens obstructions; it affords relief in the colic and all internal diseases; it comforts the heart; in short, it contains so many virtues, that they are every day discovering some new property that it has.

\section{CHAPTER III.}

\section{Of Forest Trees.}

HAVING described the most remarkable of their fruit trees, I shall now proceed to give an account of their forest trees. White and red cedars are very common upon the coast. The incorruptibility of the wood, and many other excellent properties which are well known, induced the first French settlers to build their houses of it; which were but very low. 


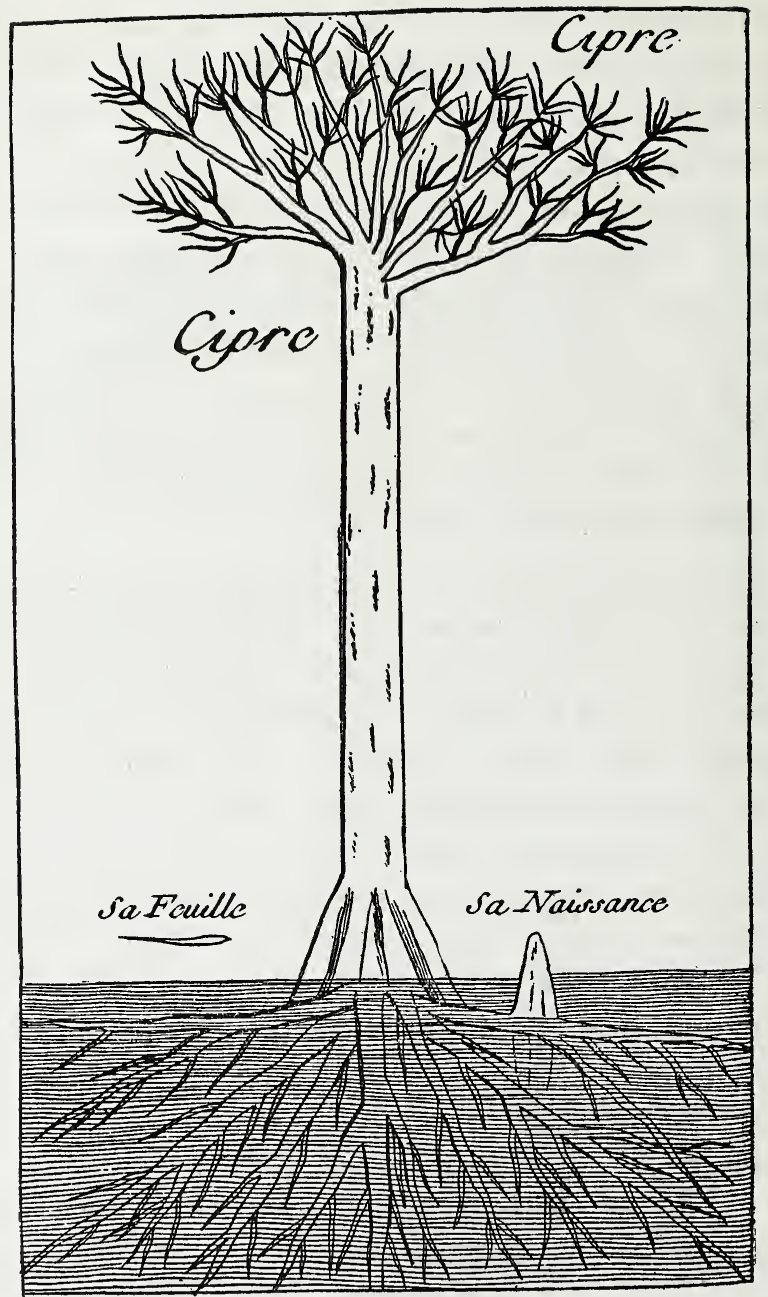

Cypress

Next to the cedar the cypress-tree is the most valuable wood. Some reckon it incorruptible; and if it be not, it is at least a great many years in rotting. The tree that was found twenty feet deep in the earth near New Orleans was a cypress, and was uncorrupted. Now if the lands of Lower Louisiana are augmented two leagues every century, this tree must have been buried at least twelve centuries. The cypress grows very straight and tall, with a proportionable thickness. They com- 
monly make their pettyaugres of a single trunk of this tree, which will carry three or four thousand weight, and sometimes more. Of one of those trees a carpenter offered to make two pettyaugres, one of which carried sixteen ton, and the other fourteen. There is a cypress at Baton Rouge, a French settlement twenty-six leagues above New Orleans, which measures twelve yards round, and is of a prodigious height. The cypress has few branches, and its leaf is long and narrow. The trunk close by the ground sometimes sends off two or three stems, which enter the earth obliquely, and serve for buttresses to the tree. Its wood is of a beautiful colour, somewhat reddish; it is soft, light, and smooth; its grain is straight, and its pores very close. It is easily split by wedges, and though used green it never warps. It renews itself in a very extraordinary manner: a short time after it is cut down, a shoot is observed to grow from one of its roots exactly in the form of a sugar-loaf, and this sometimes rises ten feet high before any leaf appears: the branches at length arise from the head of this conical shoot*.

The cypresses were formerly very common in Louisiana; but they have wasted them so imprudently, that they are now somewhat rare. They felled them for the sake of their bark, with which they covered their houses, and they sawed the wood into planks which they exported at different places. The price of the wood now is three times as much as it was formerly.

The Pine-tree, which loves a barren soil, is to be found in great abundance on the sea coasts, where it grows very high and very beautiful. The islands upon the coast, which are formed wholly of shining sand, bear no other trees, and I am persuaded that as fine masts might be made of them as of the firs of Sweden.

All the south parts of Louisiana abound with the Wild Laurel, which grows in the woods without any cultivation: the same may be said of the stone laurel; but if a person is not upon his guard he may take for the laurel a tree natural to the country, which would communicate its bad smell to every thing it is applied to. Among the laurels the preference ought to be

* This is a mistake, according to Charlevoix. 


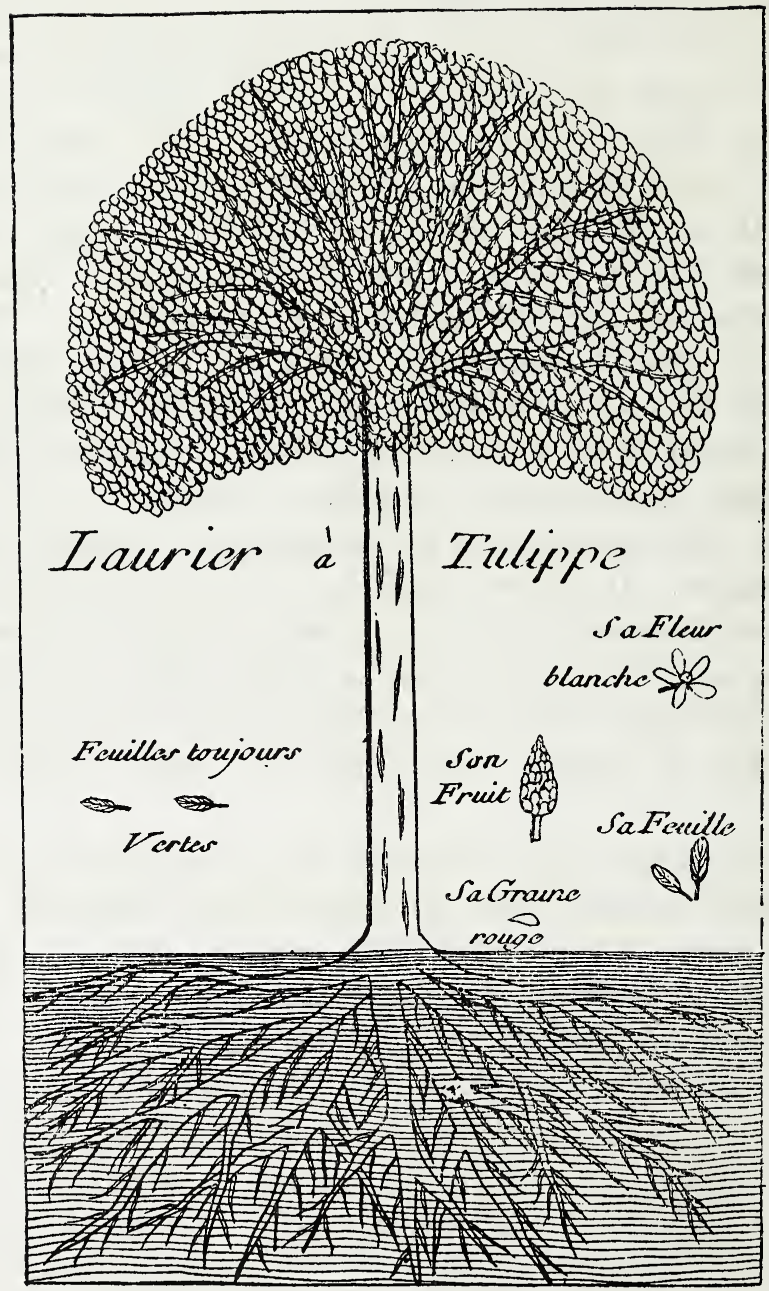

Magnolia

given to the tulip laurel (magnolia) which is not known in Europe. This tree is of the height and bulk of one of our common walnut-trees. Its head is naturally very round, and so thick of leaves that neither the sun nor rain can penetrate it. Its leaves are full four inches long, near three inches broad, and very thick, of a beautiful sea-green on the upperside, and resembling white velvet on the under-side: its bark is smooth and of a grey colour; its wood is white, soft and flexible, and 


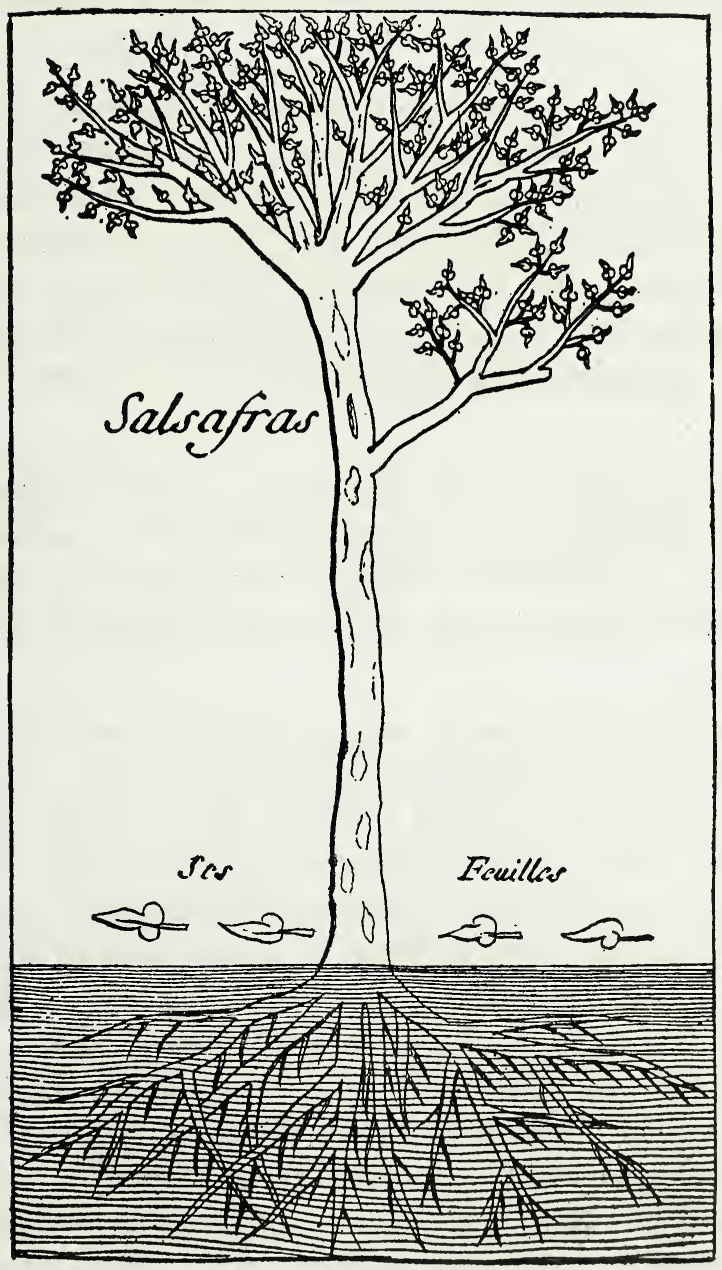

Sassafras

the grain interwoven. It owes its name to the form of its great white flowers, which are at least two inches broad. These appearing in the spring amidst the glossy verdure of the leaves, have a most beautiful effect. As the top is naturally round, and the leaves are ever-green, avenues of this tree would doubtless be worthy of a royal garden. After it has shed its leaves, its fruit appears in the form of a pine apple, and upon the first approach of the cold its grain turns into a lively red. Its 
kernel is very bitter, and it is said to be a specific against fevers.

The sassafras, the name of which is familiar to botanists on account of its medicinal qualities, is a large and tall tree. Its bark is thick, and cracked here and there; its wood is somewhat of the colour of cinnamon, and has an agreeable smell. It will not burn in the fire without the mixture of other wood, and even in the fire, if it should be separated from the flaming wood, it is immediately extinguished as if it were dipped in water.

The maple grows upon declivities in cold climates, and is much more plentiful in the northern than the southern parts of the colony. By boring it they draw from it a sweet syrup which I have drunk of, and which they alledge is an excellent stomachic.

The myrtle wax-tree is one of the greatest blessings with which nature has enriched Louisiana, as in this country the bees lodge their honey in the earth to save it from the ravages of the bears, who are very fond of it, and do not value their stings. One would be apt to take it at first sight, both from its bark and its height, for that kind of laurel used in the kitchens. It rises in several stems from the root; its leaf is like that of the laurel, but not so thick nor of such a lively green. It bears its fruit in bunches like a nosegay, rising from the same place in various stalks about two inches long: at the end of each of those stalks is a little pea, containing a kernel in a nut, which last is wholly covered with wax. The fruit, which is very plentiful, is easily gathered, as the shrub is very flexible. The tree thrives as well in the shade of other trees as in the open air; in watry places and cold countries, as well as in dry grounds and hot climates; for I have been told that some of them have been found in Canada, a country as cold as Denmark.

This tree yields two kinds of wax, one a whitish yellow, and the other green. It was a long time before they learned to separate them, and they prepared the wax at first in the following manner. They threw the grains and the stalks into a large kettle of boiling water, and when the wax was detached 


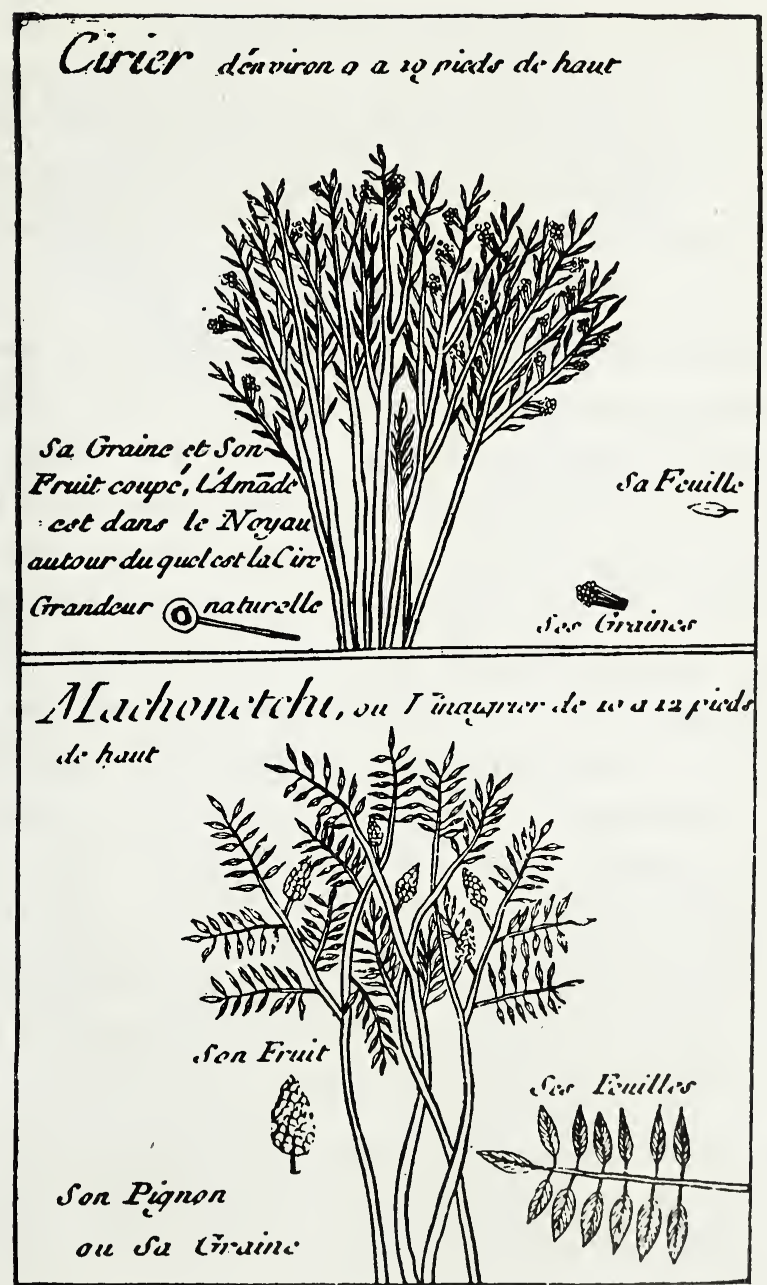

ToP: Myrtle Wax Tree-Воттом: Vinegar tree (Acacia or Locust)

from them, they scummed off the grains. When the water cooled the wax floated in a cake at the top, and being cut small, bleached in a shorter time than bees wax. They now prepare it in this manner; they throw boiling water upon the stalks and grains till they are entirely floated, and when they have stood thus a few minutes, they pour off the water, which carries the finest wax with it. This wax when cold is of a 
pale yellow colour, and may be bleached in six or seven days. Having separated the best wax, they pour the water again upon the stalks and grains, and boil all together till they think they have separated all the wax. Both kinds are exported to our sugar islands, where the first is sold for a hundred sols the pound, and the second for forty.

This wax is so brittle and dry that if it falls it breaks into several pieces; on this account however it lasts longer than that of France, and is preferred to it in our sugar islands, where the latter is softened by the great heats, and consumes like tallow. I would advise those who prepare this wax to separate the grain from the short stalk before they boil it, as the stalk is greener than the grain, and seems to part easily with its colour. The water which serves to melt and separate the wax is far from being useless. The fruit communicates to it such an astringent virtue, as to harden the tallow that is melted in it to such a degree, that the candies made of that tallow are as firm as the wax candles of France. This astringent quality likewise renders it an admirable specific against a dysentery or looseness. From what I have said of the myrtle wax-tree, it may well be believed that the French of Louisiana cultivate it carefully, and make plantations of it.

The cotton-tree (a poplar) is a large tree which no wise deserves the name it bears, unless for some beards that it throws out. Its fruit which contains the grain is about the size of a walnut, and of no use; its wood is yellow, smooth, somewhat hard, of a fine grain, and very proper for cabinet work. The bark of its root is a sovereign remedy for cuts, and so red that it may even serve to dye that colour.

The acacia (locust) is the same in Louisiana as in France, much more common, and less streight. The natives call it by a name that signifies hard wood, and they make their bows of it because it is very stiff. They look upon it as an incorruptible wood, which induced the French settlers to build their houses of it. The posts fixed in the earth must be entirely 


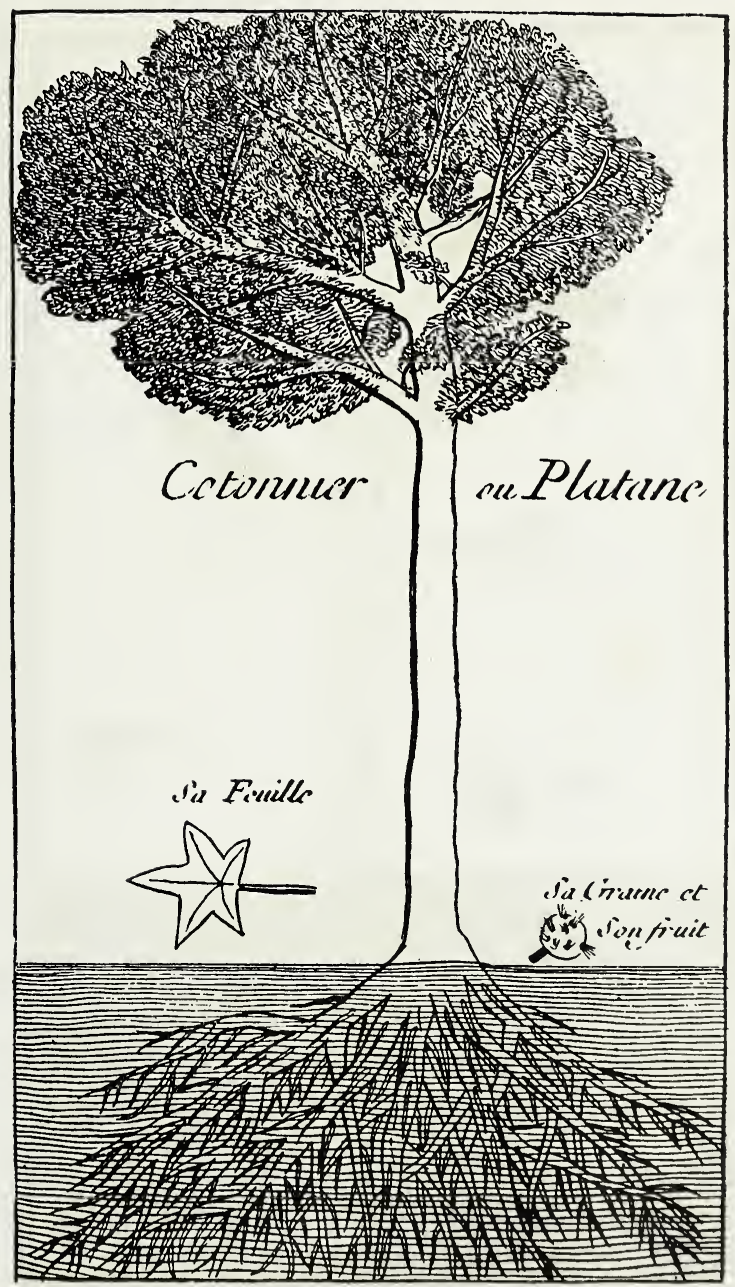

Poplar ("Cotton Tree")

stripped of their bark, for notwithstanding their hardness, if the least bark be left upon them they will take root.

The holm-oak grows to a surprising bulk and height in this country; I have seen of them a foot and a half diameter, and about 30 feet from the ground to the lowest branches.

The mangrove is very common all over America. It grows in Louisiana near the sea, even to the bounds of low water mark. It is more prejudicial than useful, inasmuch as 


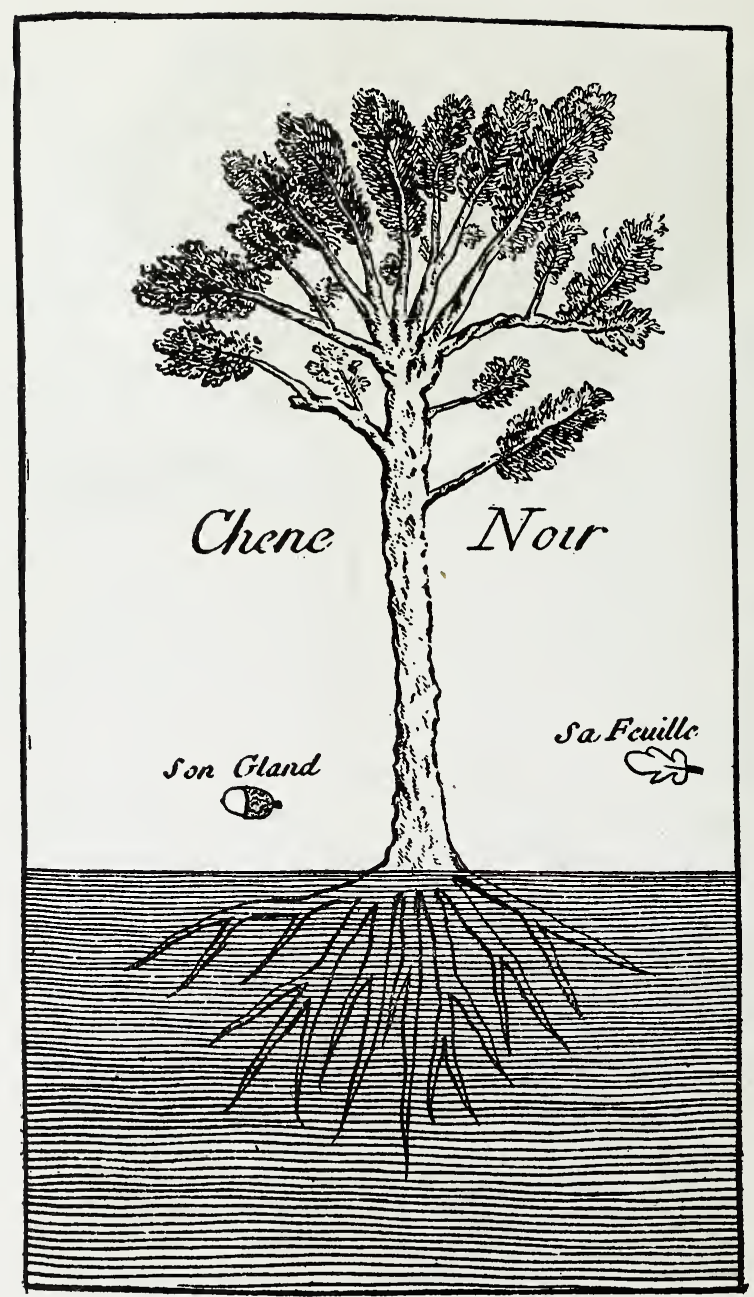

Black Oak

it occupies a great deal of good land, prevents sailors from landing, and affords shelter to the fish from the fishermen.

Oak-trees abound in Louisiana; there are some red, some white, and some ever-green. A ship-builder of St. Maloes assured me that the red is as good as the ever-green upon which we set so high a value in France. The ever-green oak is most common toward the sea-coasts, and near the banks of rivers, consequently may be transported with great ease, and 


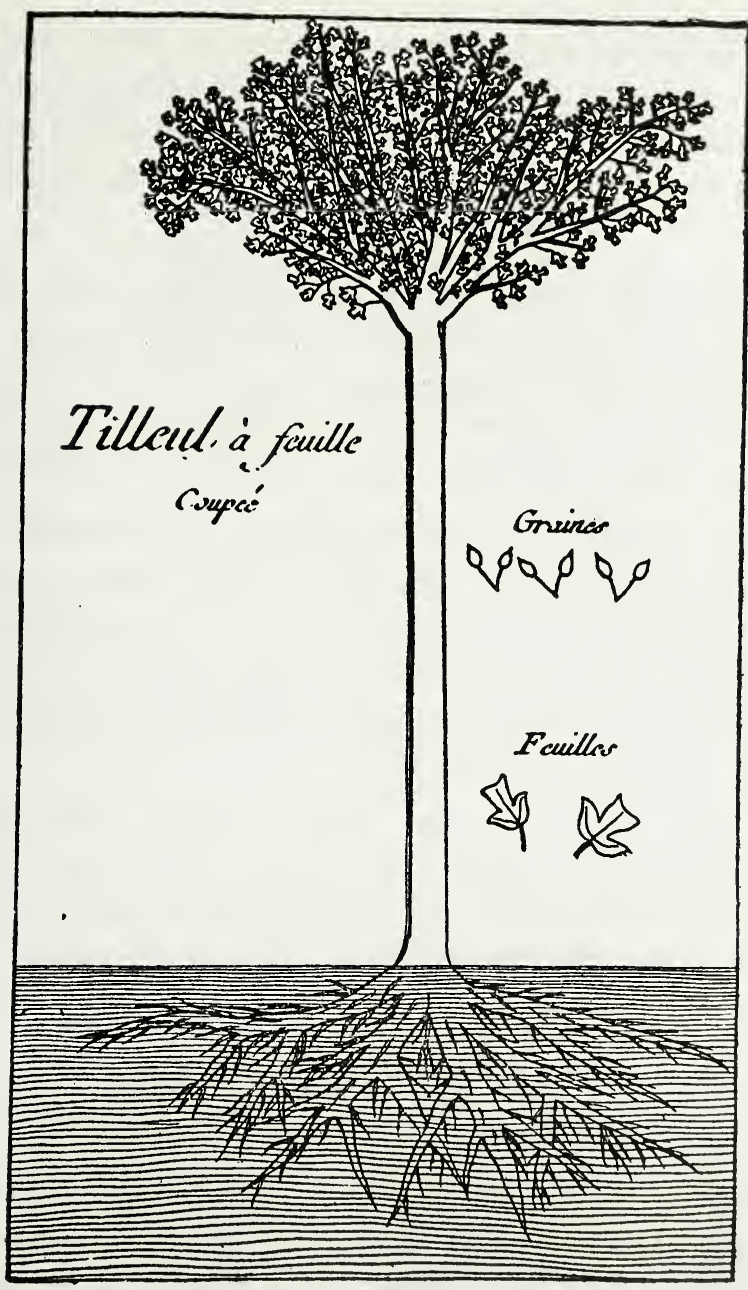

Linden or Bass Tree

become a great resource for the navy of France*. I forgot to mention a fourth kind of oak, namely the black oak, so called from the colour of its bark. Its wood is very hard, and of a

* Eleven leagues above the mouth of the Missisippi, on the west side, there is great plenty of ever-green oaks, the wood of which is very proper for the timbers of ships, as it does not rot in water. Dumont, I. \& 50.

Accordingly the best ships built in America are well known to be those that have their timbers of ever-green oak, and their plank of cedar. of both which there are great plenty on all the coasts of Louisiana. 
deep red. It grows upon the declivities of hills and in the savannahs. Happening after a shower of rain to examine one of these which I cut down, I observed some water to come from it as red as blood, which made me think that it might be used for dying.

The ash is very common in this country; but more and better upon the sea-coasts than in the inland parts. As it is easy to be had, and is harder than the elm, the wheel-wrights make use of it for wheels, which it is needless to ring with iron in a country where there are neither stones nor gravel.

The elm, beech, lime, and hornbeam, are exactly the same in Louisiana as in France; the last of these trees is very common here. The bark of the lime-tree of this country is equally proper for the making of ropes, as the bark of the common lime; but its leaf is twice as large, and shaped like an oblong trefoil leaf with the point cut off.

The white woods are the aspen, willow, alder and liart. This last grows very large, its wood is white and light, and its fibres are interwoven; it is very flexible and is easily cut, on which account they make their large pettyaugres' of it.

\section{CHAPTER IV.}

\section{Of Shrubs and Excrescences.}

THE ayac, or stinking-wood, is usually a small tree, seldom exceeding the thickness of a man's leg; its leaf is of a yellowish green, glossy, and of an oval form, being about three inches in length. The wood is yellow, and yields a water of the same colour, when it is cut in the sap: but both the wood and the water that comes from it have a disagreeable smell. The natives use the wood for dying; they cut it into small bits, pound them, and then boil them in water. Having strained this water, they dip the feathers and hair into it, which it is their custom to dye first yellow, and then red. When they intend to use it for the yellow dye, they take care to cut the wood in the winter, but if they want only a slight colour they never mind the season of cutting it. 


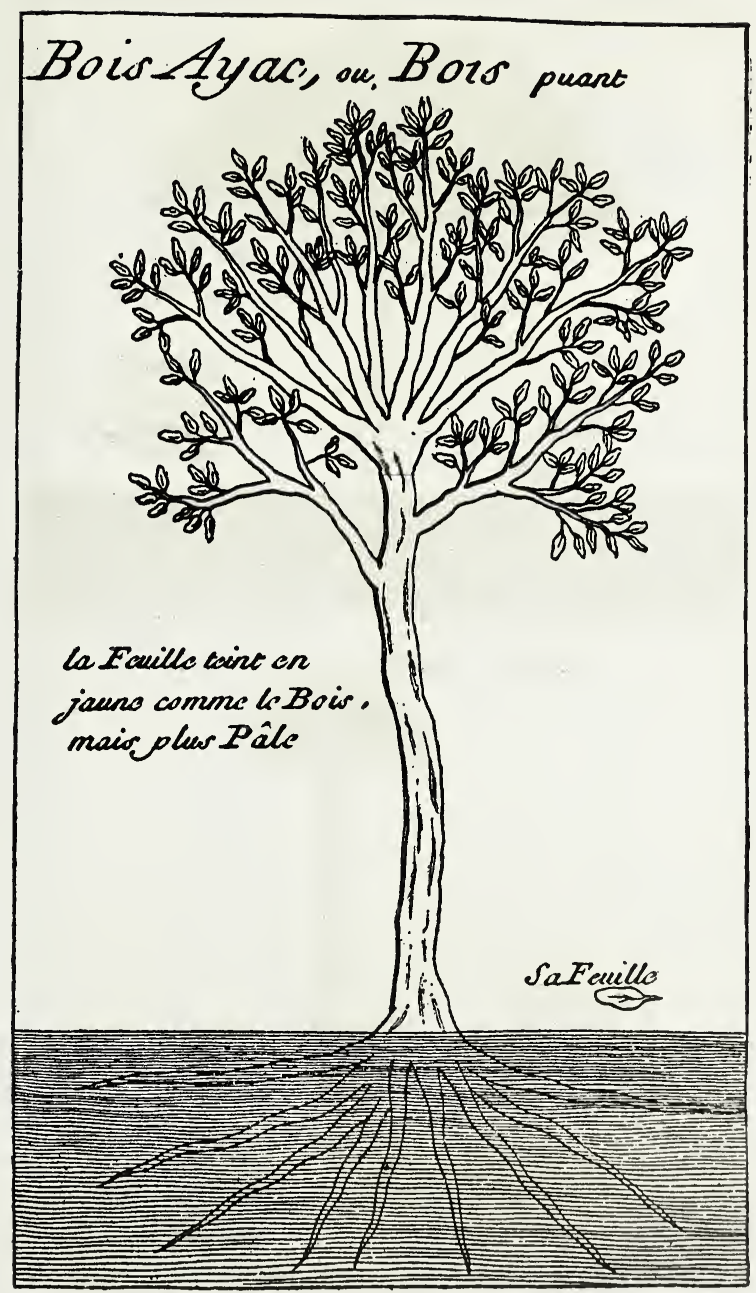

Bex Elder or Stink-wood Tree

The machonchi, or vinegar-tree, is a shrub with leaves, somewhat resembling those of the ash; but the foot-stalk from which the leaves hang is much longer. When the leaves are dry the natives mix them with their tobacco to weaken it a little, for they do not love strong tobacco for smoaking. The wood is of an astringent nature, and if put into vinegar makes it stronger. 


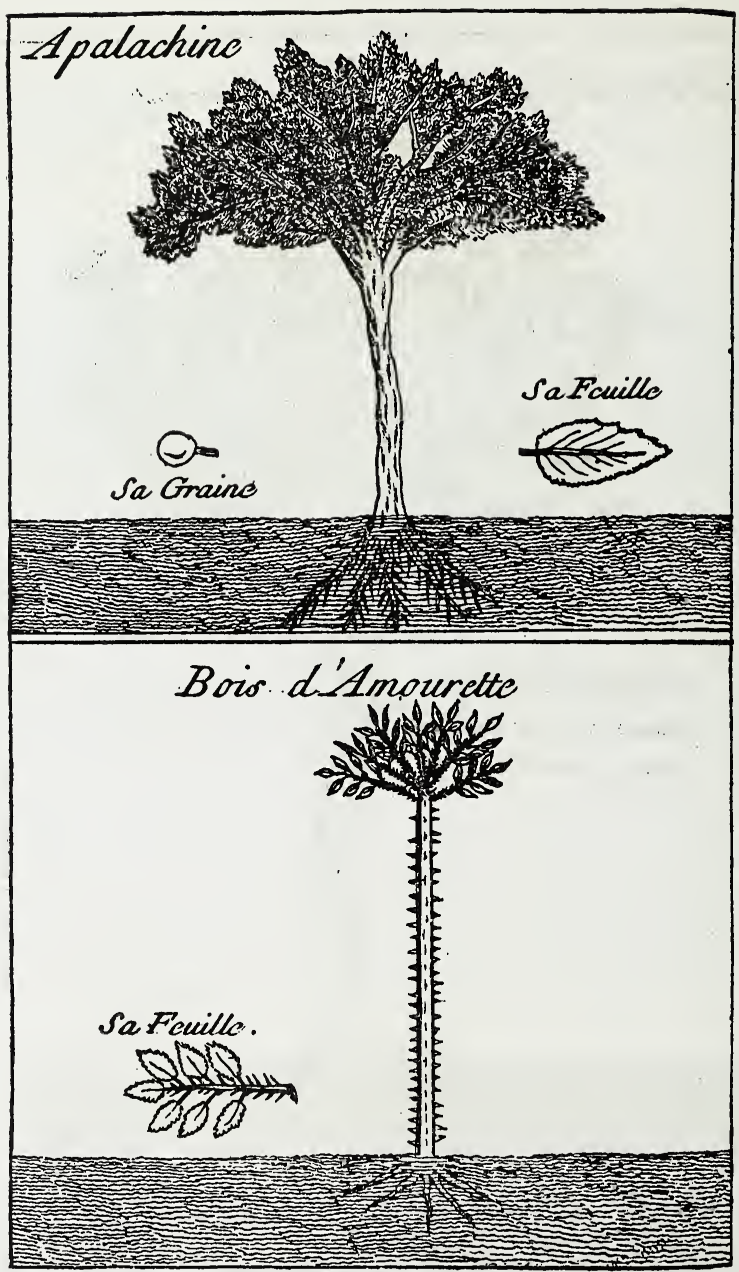

ToP: Cassine or Yapon-Bоттом: Tooth-ache Tree or Prickly Ash

The cassine, or yapon, is a shrub which never grows higher than 15 feet; its bark is very smooth, and the wood flexible. Its leaf is very much indented, and when used as tea is reckoned good for the stomach. The natives make an intoxicating liquor from it, by boiling it in water till great part of the liquor evaporate.

The toothach-tree does not grow higher than 10 to 12 feet. The trunk, which is not very large, is wholly covered over with 


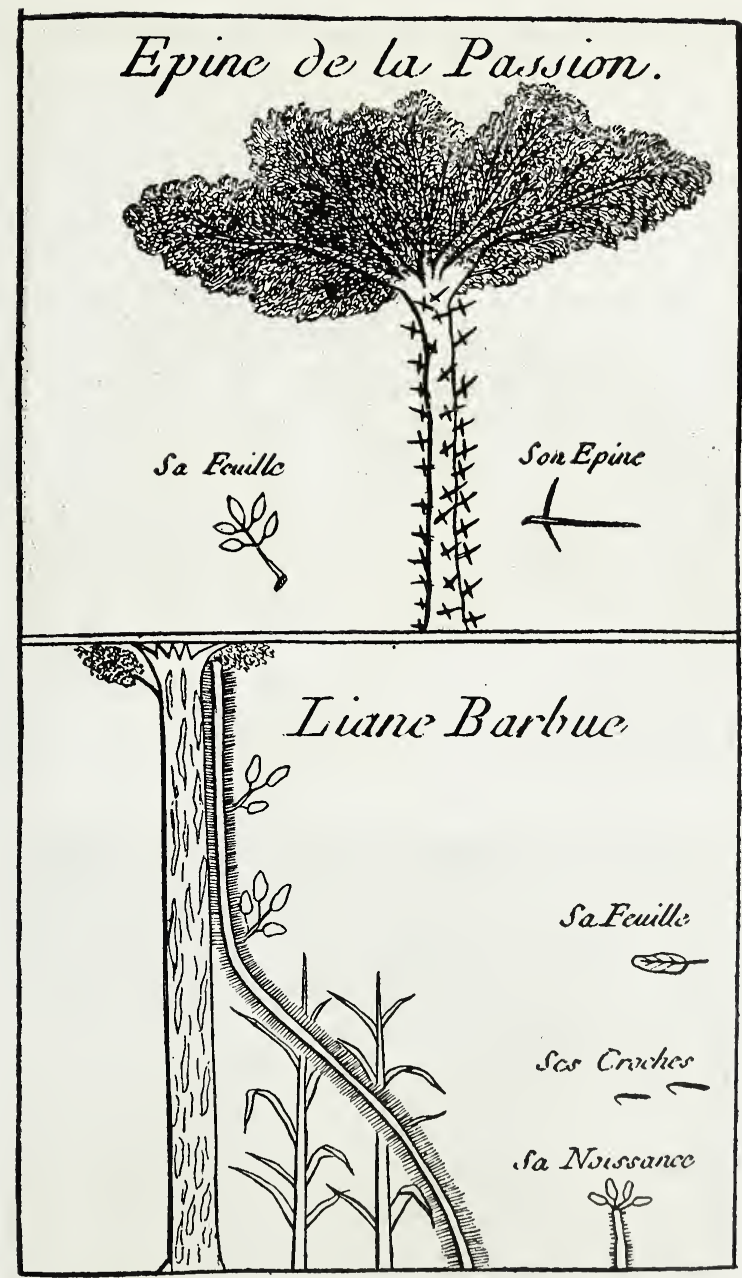

ToP: Passion Thorn or Honey LocustВоттом: Bearded Creeper

short thick prickles, which are easily rubbed off. The pith of this shrub is almost as large as that of the elder, and the form of the leaf is almost the same in both. It has two barks, the outer almost black, and the inner white, with somewhat of a pale reddish hue. This inner bark has the property of curing the tooth-ach. The patient rolls it up to the size of a bean, puts it upon the aching tooth, and chews it till the pain ceases. Sailors and other such people powder it, and use it as pepper. 


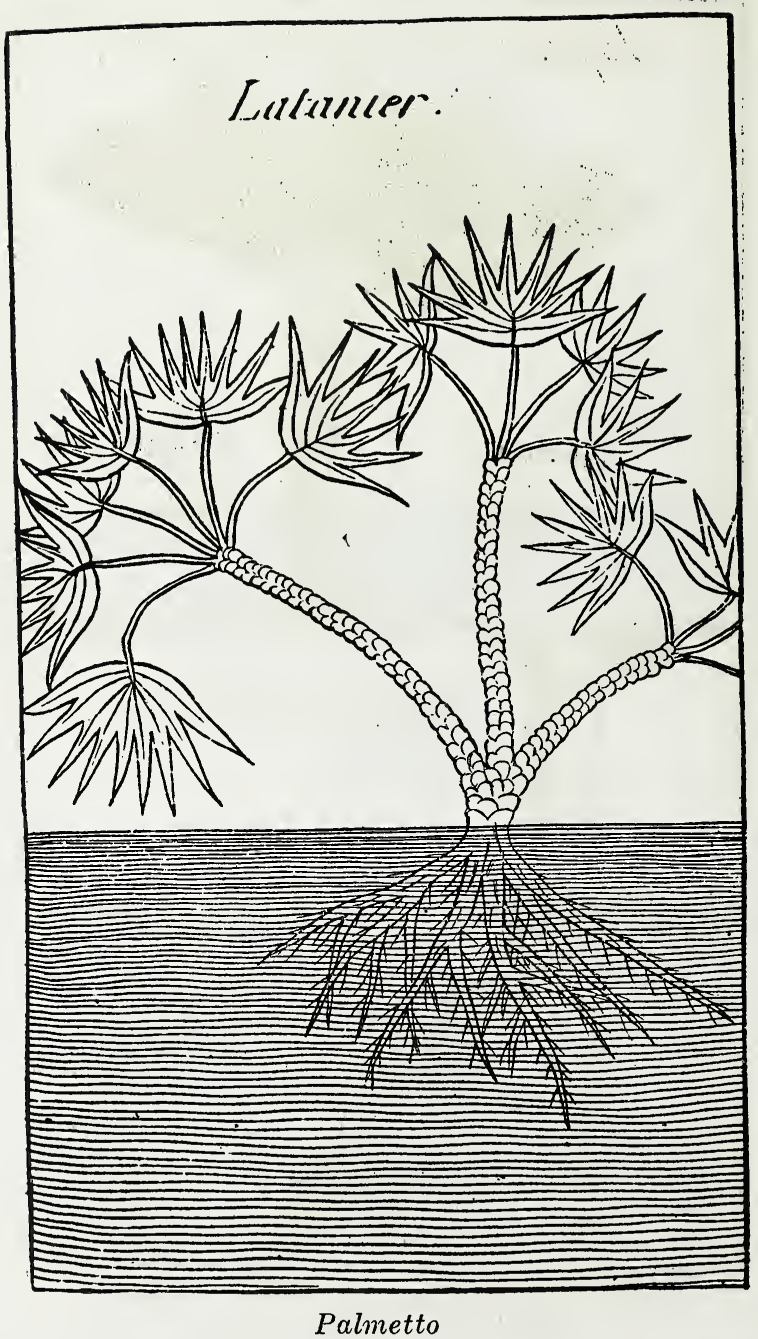

The passion-thorn does not rise above the height of a shrub; but its trunk is rather thick for its height. This shrub is in great esteem among the Natches; but I never could learn for what reason. Its leaf resembles that of the black thorn; and its wood while it is green is not very hard. Its prickles are at least two inches long, and are very hard and piercing; within half an inch of their root two other small prickles grow out from them so as to form a cross. The whole trunk is cov- 
ered with these prickles, so that you must be very wary how you approach it, or cut it.

The elder-tree is exactly like that of France, only that its leaf is a little more indented. The juice of its leaves mixed with hog's lard is a specific against the hæmorrhoids.

The palmetto has its leaves in the form of an open fan, scolloped at the end of each of its folds. Its bark is more rough and knotty than that of the palm-tree. Although it is less than that of the East Indies, it may however serve to the same purposes. Its wood is not harder than that of a cabbage, and its trunk is so soft that the least wind overturns it, so that I never saw any but what were lying on the ground. It is very common in Lower Louisiana, where there are no wild oxen; for those animals who love it dearly, and are greatly fattened by it, devour it wherever they can find it. The Spanish women make hats of its leaves that do not weigh an ounce, riding-hoods, and other curious works.

The birch-tree is the same with that of France. In the north they make canoes of its bark large enough to hold eight persons. When the sap rises they strip off the bark from the tree in one piece with wedges, after which they sew up the two ends of it to serve for stem and stern, and anoint the whole with gum.

I make not the least doubt but that there are great numbers of other trees in the forests of Louisiana that deserve to be particularly described; but I know of none, nor have I heard of any, but what I have already spoken of. For our travellers, from whom alone we can get any intelligence of those things, are more intent upon discovering game which they stand in need of for their subsistence, than in observing the productions of nature in the vegetable kingdom. To what I have said of trees, I shall only add, from my own knowledge, an account of two singular excrescences.

The first is a kind of agaric or mushroom, which grows from the root of the walnut-tree, especially when it is felled. The natives, who are very careful in the choice of their food, gather it with great attention, boil it in water, and eat it with 
their gruel. I had the curiosity to taste of it, and found it very delicate, but rather insipid, which might easily be corrected with a little seasoning.

The other excrescence is commonly found upon trees near the banks of rivers and lakes. It is called Spanish beard, which name was given it by the natives, who, when the Spaniards first appeared in their country about 240 years ago, were greatly surprised at their mustachios and beards. This excrescence appears like a bunch of hair hanging from the large branches of trees, and might at first be easily mistaken for an old perruque, especially when it is dancing with the wind. As the first settlers of Louisiana used only mud walls for their houses, they commonly mixed it with the mud for strengthening the building. When gathered it is of a grey colour, but when it is dry its bark falls off, and discovers black filaments as long and as strong as the hairs of a horse's tail. I dressed some of it for stuffing a mattress, by first laying it up in a heap to make it part with the bark, and afterwards beating it to take off some small branches that resemble so many little hooks. It is affirmed by some to be incorruptible: I myself have seen of it under old rotten trees that was perfectly fresh and strong.

\section{Chapter V. \\ Of Creeping Plants.}

THE great fertility of Louisiana renders the creeping plants extremely common, which, exclusive of the ivy, are all different from those which we have in France. I shall only mention the most remarkable.

The bearded-creeper is so called from having its whole stalk covered with a beard about an inch long, hooked at the end, and somewhat thicker than a horse's hair. There is no tree which it loves to cling to so much as to the sweet gum; and so great is its sympathy, if I may be allowed the expression, for that tree, that if it grow between it and any other tree, it turns solely towards the sweet gum, although it should be at the greatest distance from it. This is likewsie the tree upon which 
it thrives best. It has the same virtue with its balm of being a febrifuge, and this I affirm after a great number of proofs. The physicians among the natives use this simple in the following manner. They take a piece of it, above the length of the finger, which they split into as many threads as possible; these they boil in a quart of water, till one third of the decoction evaporate, and the remainder is strained clear. They then purge the patient, and the next day, upon the approach of the fit, they give a third of the decoction to drink. If the patient be not cured with the first dose, he is again purged and drinks another third, which seldom fails of having the wished-for effect. This medicine is indeed very bitter, but it strengthens the stomach; a singular advantage it has over the Jesuits bark, which is accused of having a contrary effect.

There is another creeper very like salsaparilla, only that it bears its leaves by threes. It bears a fruit smooth on one side like a filbert, and on the other as rough as the little shells which serve for money on the Guinea coast. I shall not speak of its properties; they are but too well known by the women of Louisiana, especially the girls, who very often have recourse to it.

Another creeper is called by the native physicians the remedy against poisoned arrows. It is large and very beautiful; its leaves are pretty long, and the pods it bears are narrow, about an inch broad, and eight inches long.

The salsaparilla grows naturally in Louisiana, and it is not inferior in its qualities to that of Mexico. It is so well known that it is needless to enlarge upon it.

The esquine partly resembles a creeper and partly a bramble. It is furnished with hard spikes like prickles, and its oblong leaves are like those of the common creeper (liane;) its stalk is straight, long, shining, and hard, and it runs up along the reeds: its root is spungy, and sometimes as large as one's head, but more long than round. Besides the sudorific virtue which the esquine possesses in common with the salsaparilla, it has the property of making the hair grow, and the women among the natives use it successfully with this view. 


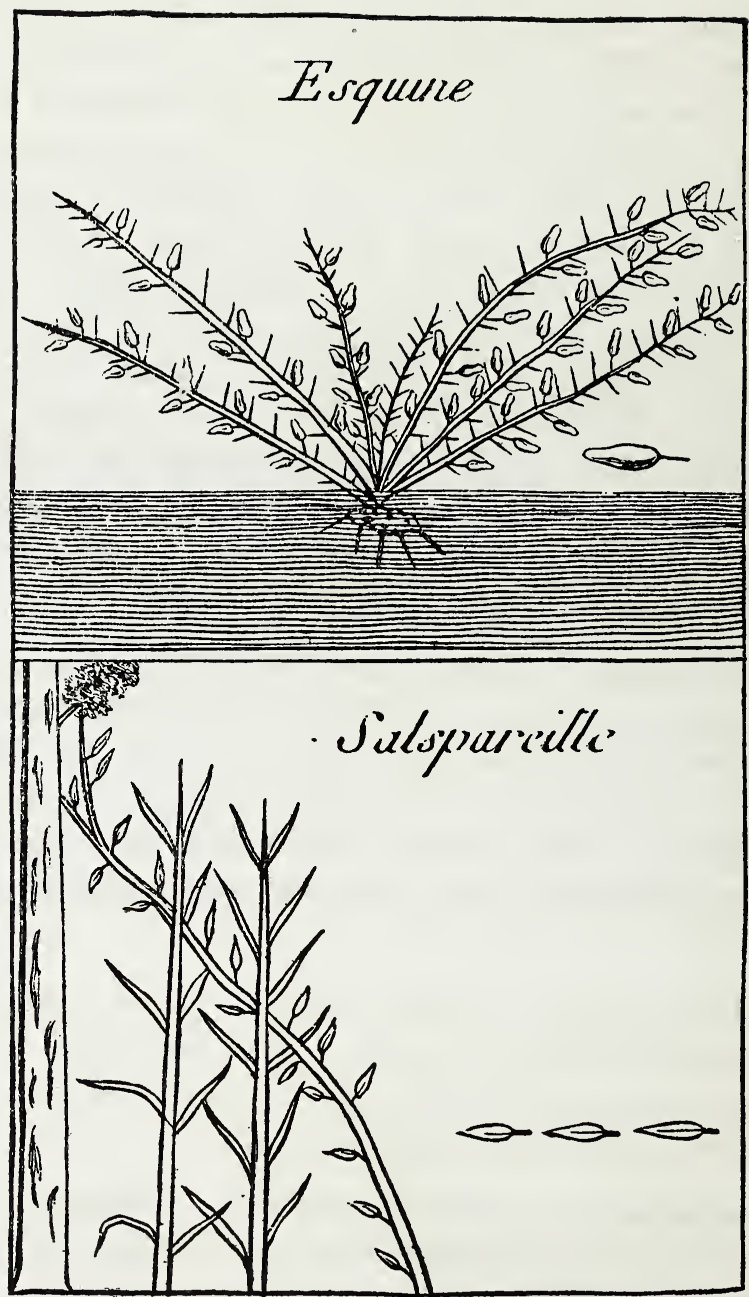

ToP: Bramble-Воттом: Sarsaparilla

They cut the root into small bits, boil them in water, and wash their heads with the decoction. I have seen several of them whose hair came down below their knees, and one particularly whose hair came lower than the ankle bones.

Hops grow naturally in the gullies in the high lands.

Maiden-hair grows in Louisiana more beautiful, at least as good as that of Canada, which is in so great repute. It 
grows in gullies upon the sides of hills, in places that are absolutely impenetrable to the most ardent rays of the sun. It seldom rises above a foot, and it bears a thick shaggy head. The native physicians know more of its virtues than we do in France.

The canes or reeds which I have mentioned so often may be divided into two kinds. One kind grows in moist places to the height of eighteen feet, and the thickness of the wrist. The natives makes matts, sieves, small boxes, and other works of it. Those that grow in dry places are neither so high nor so thick, but are so hard, that before the arrival of the French, the natives used splits of those canes to cut their victuals with. After a certain number of years, the large canes bear a great abundance of grain, which is somewhat like oats, but about three times as large. The natives carefully gather these grains and make bread or gruel of them. This flour swells as much as that of wheat. When the reeds have yielded the grain they die, and none appear for a long time after in the same place, especially if fire has been set to the old ones.

The flat-root receives its name from the form of its root, which is thin, flat, pretty often indented, and sometimes even pierced through: it is a line or sometimes two lines in thickness, and its breadth is commonly a foot and a half. From this large root hang several other small straight roots, which draw the nourishment from the earth. This plant, which grows in meadows that are not very rich, sends up from the same root several straight stalks about eighteen inches high, which are as hard as wood, and on the top of the stalks it bears small purplish flowers, in their figure greatly resembling those of heath; its seed is contained in a deep cup closed at the head, and in a manner crowned. Its leaves are about an inch broad, and about two long, without any indenting, of a dark green, inclining to a brown. It is so strong a sudorific, that the natives never use any other for promoting sweating, although they are perfectly acquainted with sassafras, salsaparilla, the esquine and others.

The rattle-snake-herb has a bulbous root, like that of the tuberose, but twice as large. The leaves of both have the same 


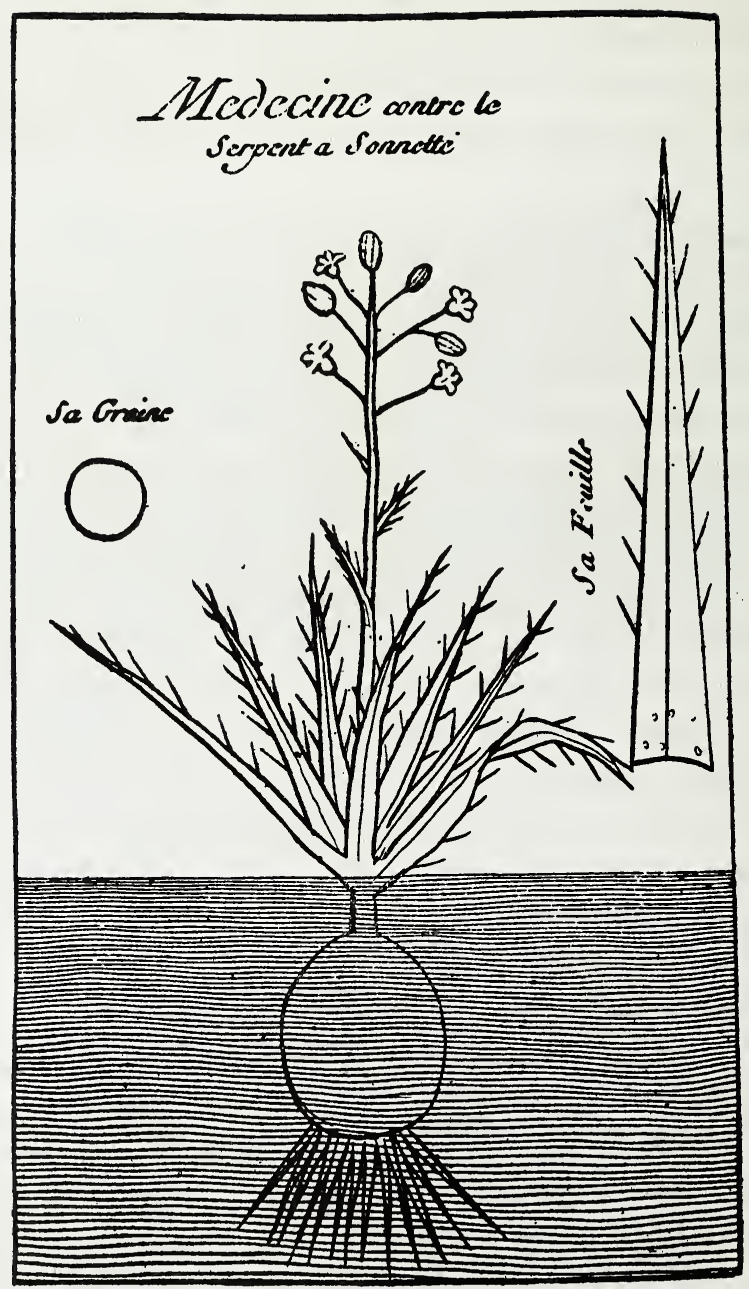

Rattlesnake herb

shape and the same colour, and on the under side have some flame-coloured spots; but those of the rattle-snake plant are twice as large as the others, end in a very firm point, and are armed with very hard prickles on both sides. Its stalk grows to the height of about three feet, and from the head rise five or six sprigs in different directions, each of which bears a purple flower an inch broad, with five leaves in the form of a 
cup. After these leaves are shed there remains a head about the size of a small nut, but shaped like the head of a poppy. This head is separated into four divisions, each of which contains four black seeds, equally thick throughout, and about the size of a large lentil. When the head is ripe, it will, when shaken, give the same sound as the tail of a rattle-snake, which seems to indicate the property of the plant; for it is the specific remedy against the bite of that dangerous reptile. The person who has been bit ought immediately to take a root, bite off part of it, chew it for some time, and apply it to the wound. In five or six hours it will extract the whole poison, and no bad consequences need be apprehended.

Ground-ivy is said by the natives to possess many more virtues than are known to our botanists. It is said to ease women in labour when drank in a decoction; to cure ulcers, if bruised and laid upon the ulcered part; to be a sovereign remedy for the head-ach; a considerable quantity of its leaves bruised, and laid as a cataplasm upon the head, quickly removes the pain. As this is an inconvenient application to a person that wears his hair, I thought of taking the salts of the plant, and I gave some of them in vulnerary water to a friend of mine who was often attacked with the head-ach, advising him likewise to draw up some drops by the nose: he seldom practised this but he was relieved a few moments after.

The Achechy is only to be found in the shade of a wood, and never grows higher than six or seven inches. It has a small stalk, and its leaves are not above three lines long. Its root consists of a great many sprigs a line in diameter, full of red juice like chickens blood. Having transplanted this plant from an overshadowed place into my garden, I expected to see it greatly improved; but it was not above an inch taller, and its head was only a little bushier than usual. It is with the juice of this plant that the natives dye their red colour. Having first dyed their feathers or hair yellow or a beautiful citron colour with the ayac wood, they boil the roots of the achechy in water, then squeeze them with all their force, and the expressed liquor serves for the red dye. That which was naturally white before it was dyed yellow, takes a beautiful scarlet; 


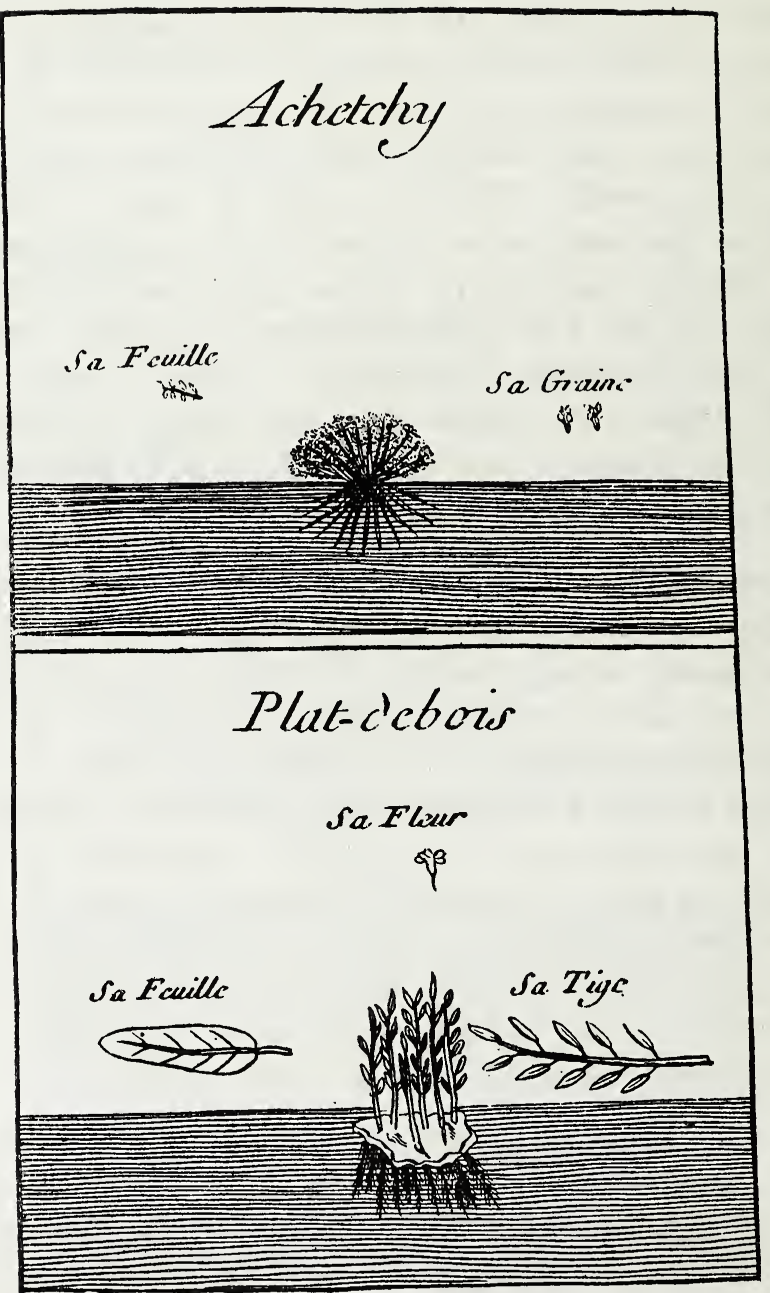

ToP: Red Dye Plant-BoтTom: Flat Root

that which was brown, such as buffalo's hair, which is of a chesnut colour, becomes a reddish brown.

I shall not enlarge upon the strawberries, which are of an excellent flavour, and so plentiful, that from the beginning of April the savannahs or meadows appear quite red with them. I shall also only just mention the tobacco, which I reserve for the article of agriculture; but I ought not to omit to take notice, that hemp grows naturally on the lands adjoining to the lakes 
on the west of the Missisippi. The stalks are as thick as one's finger, and about six feet long. They are quite like ours both in the wood, the leaf, and the rind. The flax which was sown in this country rose three feet high.

I cannot affirm from my own knowledge that the soil in this province produces either white mushrooms or truffles. But morelles in their season are to be found in the greatest abundance, and round mushrooms in the autumn.

When I consider the mild temperature of this climate, I am persuaded that all our flowers would succeed extremely well in it. The country has flowers peculiar to itself, and in such abundance, that from the month of May till the end of summer, you can hardly see the grass in the meadows; and of such various hues that one is at a loss which to admire most and declare to be the most beautiful. The number and diversity of those flowers quite enchant the sight. I will not however attempt to give a particular account of them, as I am not qualified on this head to satisfy the desires of the curious, from my having neglected to consider the various flowers themselves. I have seen single and small roses without any smell; and another kind of rose with four white petals, which in its smell, chives, and pointal, differed in nothing from our damask roses. But of all the flowers of this country, that which struck me most, as it is both very common and lasts a long time, is the flower called Lion's Mouth. The flowers which decorate its stalk, its shady colours, its blowing for more than three months, justly entitle it to the preference before all other flowers. It forms of itself an agreeable nosegay; and in my opinion, it deserves to be ranked with the finest flowers, and to be cultivated with attention in the gardens of our kings.

As to cotton and indigo, I defer speaking of them till I come to the chapter of agriculture. 


\section{Chapter VI. \\ Of the Quadrupedes.}

$\mathrm{B}^{\mathrm{EFORE}}$ I speak of the animals which the first settlers found in Louisiana, it is proper to observe, that all those which were brought hither from France, or from New Spain and Carolina, such as horses, oxen, sheep, goats, dogs, cats, and others, have multiplied and thriven perfectly well. However it ought to be remarked, that in Lower Louisiana, where the ground is moist and much covered with wood, they can neither be so good nor so beautiful as in Higher Louisiana, where the soil is dry, where there are most extensive meadows, and where the sun warms the earth to a much greater degree.

The buffalo is about the size of one of our largest oxen, but he appears rather bigger, on account of his long curled wool, which makes him appear to the eye much larger than he really is. This wool is very fine and very thick, and is of a dark chesnut colour, as are likewise his bristly hairs, which are also curled, and so long, that the bush between his horns often falls over his eyes, and hinders him from seeing before him; but his sense of hearing and smelling is so exquisite as in some measure to supply the want of the other. A pretty large bunch rises on his shoulders in the place where they join to the neck. His horns are thick, short, and black; and his hoof is also black. The cows of this species have small udders like those of a mare.

This buffalo is the chief food of the natives, and of the French also for a long time past; the best piece is the bunch on the shoulders, the taste of which is extremely delicate. They hunt this animal in the winter; for which purpose they leave Lower Louisiana, and the river Missisippi, as he cannot penetrate thither on account of the thickness of the woods; and besides loves to feed on long grass, which is only to be found in the meadows of the high lands. In order to get near enough to fire upon him, they go against the wind, and they take aim at the hollow of the shoulder, that they may bring him to the ground at once, for if he is only slightly wounded, he runs against his enemy. The natives when hunting seldom 


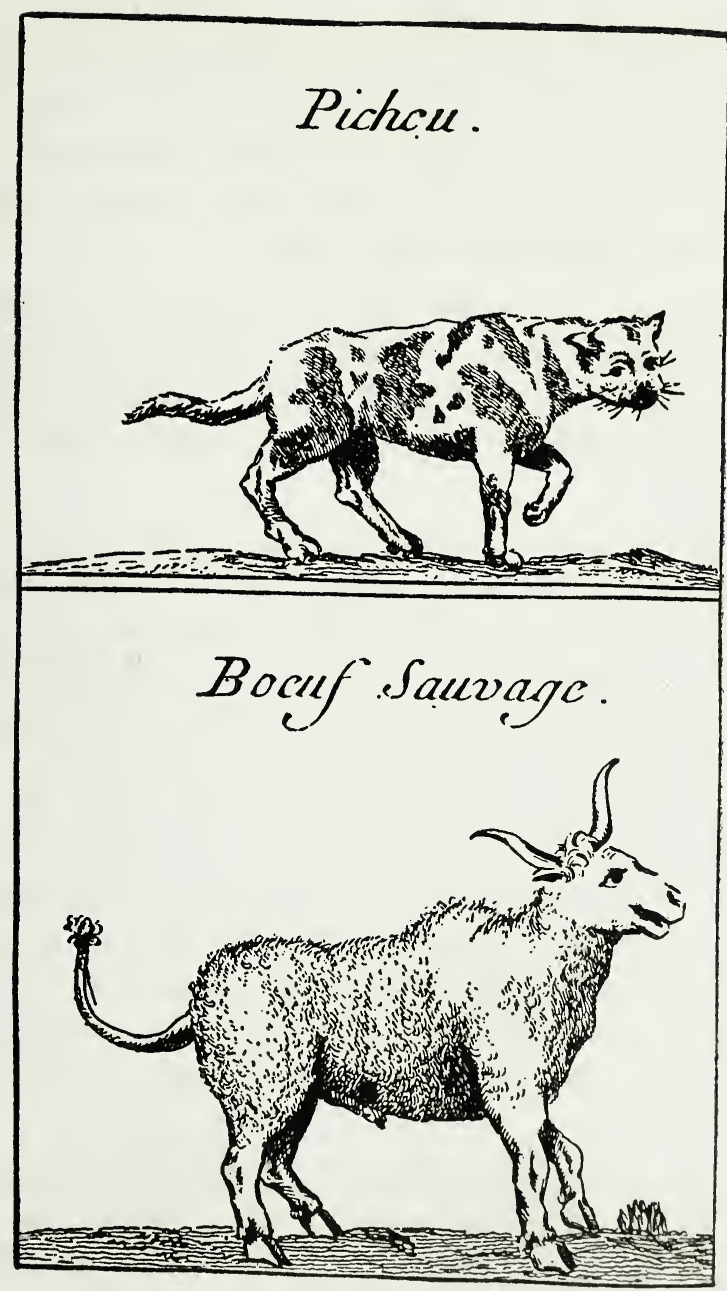

Top: Panther or Catamount-Воттом: Bison or Buffalo

choose to kill any but the cows, having experienced that the flesh of the male smells rank; but this they might easily prevent, if they did but cut off the testicles from the beast as soon as he is dead, as they do from stags and wild boars. By killing the males there is less hazard of diminishing the species than by killing the females; and besides, the males have much more tallow, and their skins are the largest and best. 
These skins are an object of no small consideration. The natives dress them with their wool on, to such great perfection, as to render them more pliable than our buff. They dye them different colours, and cloath themselves therewith. To the French they supply the place of the best blankets, being at the same time very warm and very light.

The stag is entirely the same with that of France, only he is a little larger. They are only to be found in Upper Louisiana, where the woods are much thinner than in Lower Louisiana, and the chesnuts which the stag greatly loves are very common.

The deer is very frequent in this province, notwithstanding the great numbers of them that are killed by the natives. According to the hunters, he partly resembles the stag, the rein-deer, and the roe-buck. As to myself, I can only say what I have seen; that he is about four feet high, has large horns bending forwards, and decorated with several antlers, the ends of which are formed somewhat like a rose; that his flesh is dry like that of ours, and when he is fat tastes like mutton. They feed in herds, and are not in the least of a fierce nature. They are excessively capricious, hardly remain a moment in one place, but are coming and going continually. The natives dress the skin extremely well, like buff, and afterwards paint it. Those skins that are brought to France are often called does skins.

The natives hunt the deer sometimes in companies, and sometimes alone. The hunter who goes out alone, furnishes himself with the dried head of a deer, with part of the skin of the neck fastened to it, and this skin is stretched out with several hoops made of split cane, which are kept in their places by other splits placed along the inside of the skin, so that the hands and arms may be easily put within the neck. Being thus provided, he goes in quest of the deer, and takes all necessary precautions not to be discovered by that animal: when he sees one, he approaches it as gently as possible, hiding himself behind a bush which he carries in his hand, till he be within shot of it. But if, before he can come near enough, the buck shakes its head, which is a sign that he is going to make some 


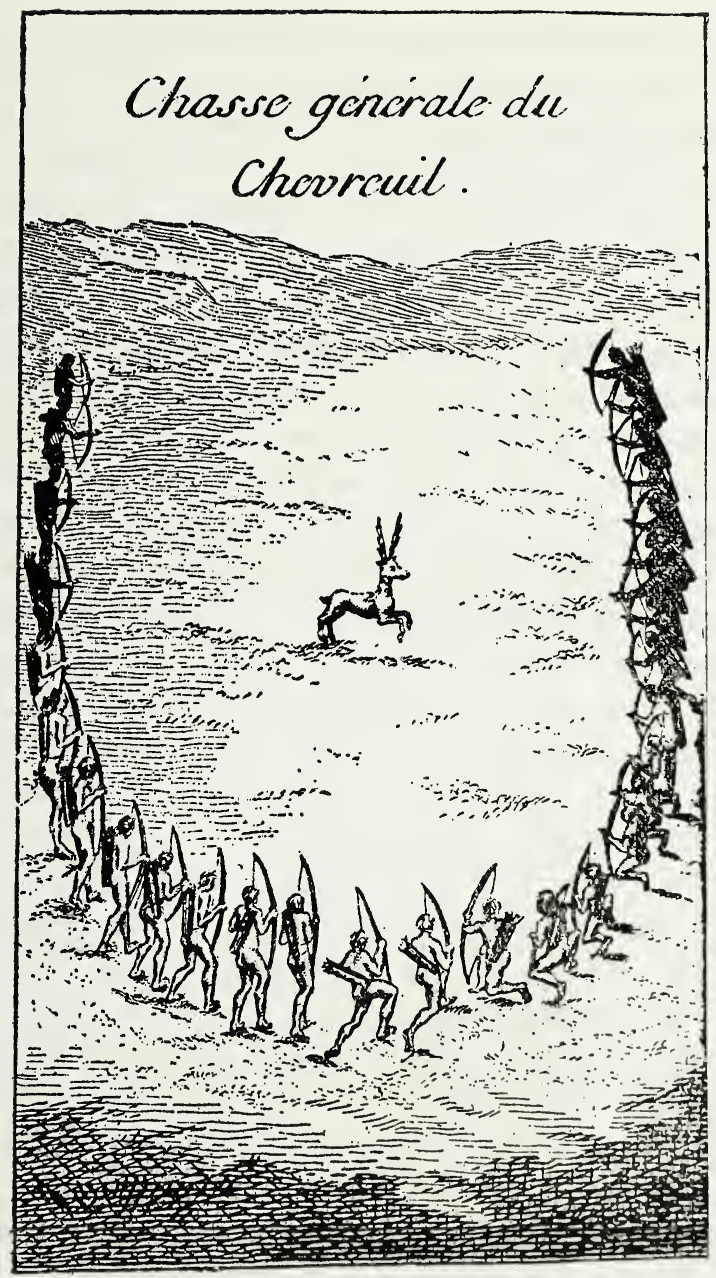

Indian Deer Hunt

capers and run away, the hunter immediately counterfeits the cries of those animals when they call each other, in which case the buck frequently comes up towards him. He then shews the head which he holds in his hand, and by lowering and lifting his arm by turns, it makes the appearance of a buck feeding, and lifting his head from time to time to graze. The hunter still keeps himself behind the bush, till the buck comes near enough to him, and the moment he turns his side, he fires at the hollow of his shoulder, and lays him dead. 
When the natives want to make the dance of the deer; or if they want to exercise themselves merrily; or if it should happen that the Great Sun inclines to such sport, they go about an hundred of them in a company to the hunting of this animals, which they must bring home alive. As it is a diverting exercise, many young men are generally of the party, who disperse themselves in the meadows among the thickets in order to discover the deer. They no sooner perceive one than they advance towards him in a wide crescent, one point of which may be a quarter of a league from the other. Part of the crescent draws near to him, which frightens him away to another point; that part likewise advancing, he immediately flies back to the other side. He is kept thus running from one side to another a considerable time, on purpose to exercise the young men, and afford diversion to the Great Sun, or to another Little Sun, who is nominated to supply his place. The deer sometimes attempts to get out and escape by the openings of the crescent, in which case those who are at the points run forwards, and oblige him to go back. The crescent then gradually forms a circle; and when they perceive the deer beginning to be tired, part of them stoop almost to the ground, and remain in that posture till he approaches them, when they rise and shout: he instantly flies off to the other side, where they do the same; by which means he is at length so exhausted, that he is no longer able to stand on his legs, and suffers himself to be taken like a lamb. Sometimes, however, he defends himself on the ground with his antlers and forefeet; they therefore use the precaution to seize upon him behind, and even in that case they are sometimes wounded.

The hunters having seized the deer present it to the Great Sun, or in his absence, to the person whom he sent to represent him. If he says, well, the roe-buck is immediately opened, and its four quarters carried to the hut of the Great Sun, who gives portions of them to the chief men among the hunters.

The wolf is not above fifteen inches high, and of a proportionable length. He is not so brown as our wolves, nor so fierce and dangerous; he is therefore more like a dog than a wolf, especially the dog of the natives, who differs from him 
in nothing, but that he barks. The wolf is very common in the hunting countries; and when the hunter makes a hut for himself in the evening upon the bank of a river, if he sees the wolf, he may be confident that the buffaloes are not at a very great distance. It is said, that this animal, not daring to attack the buffalo when in a herd, will come and give notice to the hunter that he may kill him, in hopes of coming in for the offals. The wolves are actually so familiar, that they come and go on all sides when looking for something to eat, without minding in the least whether they be near or at a distance from the habitations of men.

In my time two very large black wolves were seen in Louisiana. The oldest inhabitants, and those who travel to the remotest parts of the colony, declared that they had never before seen any such; from whence it was concluded, that they were foreign wolves which had lost their way. Fortunately they killed them both; for one of them was a she-wolf big with young.

The bear appears in Louisiana in winter, as the snows, which then cover the northern climates, hinder him from procuring a subsistence there, and force him southwards.. If some few are seen in the summer time, they are only the slow young bears, that have not been strong enough to follow the herd northwards. The bear lives upon roots and fruits, particularly acorns; but this most delicate food is honey and milk. When he meets with either of these last, he will suffer himself to be killed than quit his prize. Our colonists have sometimes diverted themselves by burying a small pail with some milk in it almost up to the edge in the ground, and setting two young bears to it. The contest then was which of the two should hinder the other from tasting the milk, and both of them so tore the earth with their paws, and pulled at the pail, that they generally overturned the milk, before either of them had tasted of it.

In opposition to the general opinion, which supposes the bear a carnivorous animal, I affirm, with all the inhabitants of this colony, and the neighbouring countries, that he never feeds upon flesh. It is indeed to be lamented that the first 
travellers had the impudence to publish to the world a thousand false stories, which were easily believed because they were new. People, so far from wishing to be undeceived, have even been offended with those who attempted to detect the general errors; but it is my duty to speak the truth, for the sake of those who are willing to hear it. What I maintain here is not a mere conjectural supposition, but a known fact over all North America, which may be attested by the evidence of a great number of people who have lived there, and by the traders who are going and coming continually. There is not one instance can be given of their having devoured men, notwithstanding their great multitudes, and the extreme hunger which they must sometimes have suffered; for even in that case they never so much as touch the butchers meat which they meet with.

The bears seldom quit the banks of the Missisippi, as it is there that they can best procure a subsistence; but when I lived at the Natchez there happened so severe a winter, that those animals came from the north in such numbers that they starved each other, and were very lean. Their great hunger obliged them to quit the woods which line the banks of the river: they were seen at night running among the settlements; and they sometimes even entered those court-yards that were not well shut; they there found butchers meat exposed to the open air, but they never touched it, and eat only the corn or roots they could meet with. Certainly on such occasion as this, and in such a pressing want, they would have proved carnivorous, if it had been in the least degree their natural disposition.

But perhaps one will say, "It is true they never touch dead flesh; it is only living flesh that they devour." That is being very delicate indeed, and what I can by no means allow them: for if they were flesh-eaters, I greatly suspect that, in the severe famine which I have spoken of, they would have made a hearty meal of the butchers meat which they found in the court-yards; or at least would have devoured several persons who fell in their way, which they never did. The following fact however will be a more compleat answer to this objection. 
Two Canadians, who were on a journey, landed on a sandbank, when they perceived a bear crossing the river. As. he appeared fat, and consequently would yield a great deal of oil, one of the travellers ran forwards and fired at him. Unhappily however he only slightly wounded him; and as the bears in that case always turn upon their enemy, the hunter was immediately seized by the wounded bear, who in a few moments squeezed him to death, without wounding him in the least with his teeth, although his muzzle was against his face, and he must certainly have been exasperated. The other Canadian, who was not above three hundred paces distance, ran to save his comrade with the utmost speed, but he was dead before he came up to him; and the bear escaped into the wood. Upon examining the corpse he found the place, where the bear had squeezed it, pressed in two inches more than the rest of the breast.

Some perhaps may still add, that the mildness of the climate of Louisiana may have an effect upon the disposition of the bears, and prevent them from being so voracious as those of our continent; but I affirm that carnivorous animals retain the same disposition in all countries. The wolves of Louisiana are carnivorous as well as those of Europe, although they differ in other particulars. The tigers of Africa, and those of America, are equally mischievous animals. The wildcats of America, though very different from those of Europe, have however the same appetite for mice when they are tamed. It is the same with other species, naturally inclined to live upon other animals; and the bears of America, if flesh-eaters, would not quit the countries covered with snow, where they would find men and other animals in abundance, to come so far in search of fruits and roots; which kind of nourishment carnivorous animals refuse to taste*.

Bears are seen very frequently in Louisiana in the winter time, and they are so little dreaded, that the people sometimes

\footnotetext{
* Since I wrote the above account of the bears, I have been certainly informed, that in the mountains of Savoy there are two sorts of bears. The one black, like that of Louisiana, and not carnivorous; the other red. and no less carnivorous than the wolves. Both turn upon their enemy when wounded.
} 
make it a diversion to hunt them. When they are fat, that is about the end of December, they cannot run so fast as a man; therefore the hunters are in no danger if they should turn upon them. The she-bears are tolerably fat when they are big with young; but after they have littered they quickly become lean.

The bears usually arrive in Louisiana towards the end of autumn; and then they are very lean, as they do not leave the north till the earth be wholly covered with snow, and find often but a very scanty subsistence in their way southwards. I said above, that those animals seldom go to any great distance from the river; and on both banks travellers meet with such a beaten path in winter, that to those who are not acquainted with it, it appears like the track of men. I myself, the first time I observed it, was deceived by it. I was then near two hundred miles from any human dwelling, yet the path at first appeared to me as if it had been made by thousands of men, who had walked that way bare-footed. Upon a narrower inspection however, I observed, that the prints of the feet were shorter than that of a man, and that there was the impression of a claw at the end of each toe. It is proper to observe that in those paths the bear does not pique himself upon politeness, and will yield the way to nobody; therefore it is prudent in a traveller not to fall out with him for such a trifling affair.

The bears, after they have been a short time in the country, and found abundance of fruits, turn fat and lazy, and it is then the natives go out to hunt them. The bear, when he is fat, huts himself, that is, retires into the hollow trunk of some rotten tree that has died on end. The natives, when they meet with any of those trees, which they suspect contains a bear in it, give two or three strong blows against the trunk, and immediately run behind the next tree opposite to the lowest breach. If there be a bear within, he appears in a few minutes at the breach, to look out and spy the occasion of the disturbance; but upon observing nothing likely to annoy him, he goes down again to the bottom of his castle.

The natives having once seen their prey, gather a heap of dried canes, which they bruise with their feet, that they may 
burn the easier, and one of them mounting upon a tree adjoining to that in which the bear is, sets fire to the reeds, and darts them one after another into the breach; the other hunters having planted themselves in ambuscade upon other trees. The bear is quickly burned out of his habitation, and he no sooner appears on the outside, than they let fly their arrows at him, and often kill him before he gets to the bottom of the tree.

$\mathrm{He}$ is no sooner dead than some of the hunters are dispatched to look for a deer, and they seldom fail of bringing in one or two. When a deer is brought, they cut off the head, and then take off the skin whole, beginning at the neck, and rolling it down, as they cut it, like a stocking. The legs they cut off at the knee-joints, and having cleaned and washed the skin, they stop all the holes except the neck, with a kind of paste made of the fat of the deer mixed with ashes, over which they tie several bindings with the bark of the lime-tree. Having thus provided a kind of cask, they fill it with the oil of the bear, which they prepare by boiling the flesh and fat together. This Deer of Oil, as it is called, they sell to the French for a gun, a yard of cloth, or any other thing of that value. The French, before they use it, purify it, by putting it into a large kettle, with a handful of laurel leaves; and sprinkling it when it begins to be hot with some water, in which they have dissolved a large quantity of salt. The smoke that rises upon this sprinkling carries off with it any bad smell the fat may have; they next pour it off into a vessel, and eight days after there is found on the top of it a clear oil which serves all the purposes of olive oil; what remains below is a fine kind of lard, proper for the kitchen, and a sovereign remedy for all kinds of pains. I myself was cured of the rheumatism in my shoulder by it.

The Tiger is not above a foot and a half high, and long in proportion: his hair is somewhat of a bright bay colour, and he is brisk as all tigers naturally are. His flesh when boiled tastes like veal, only it is not so insipid. There are very few of them to be seen; I never saw but two near my settlement; and I have great reason to think that it was the same beast I saw both times. The first time he laid hold of my dog, who barked and howled; but upon my running towards him the 


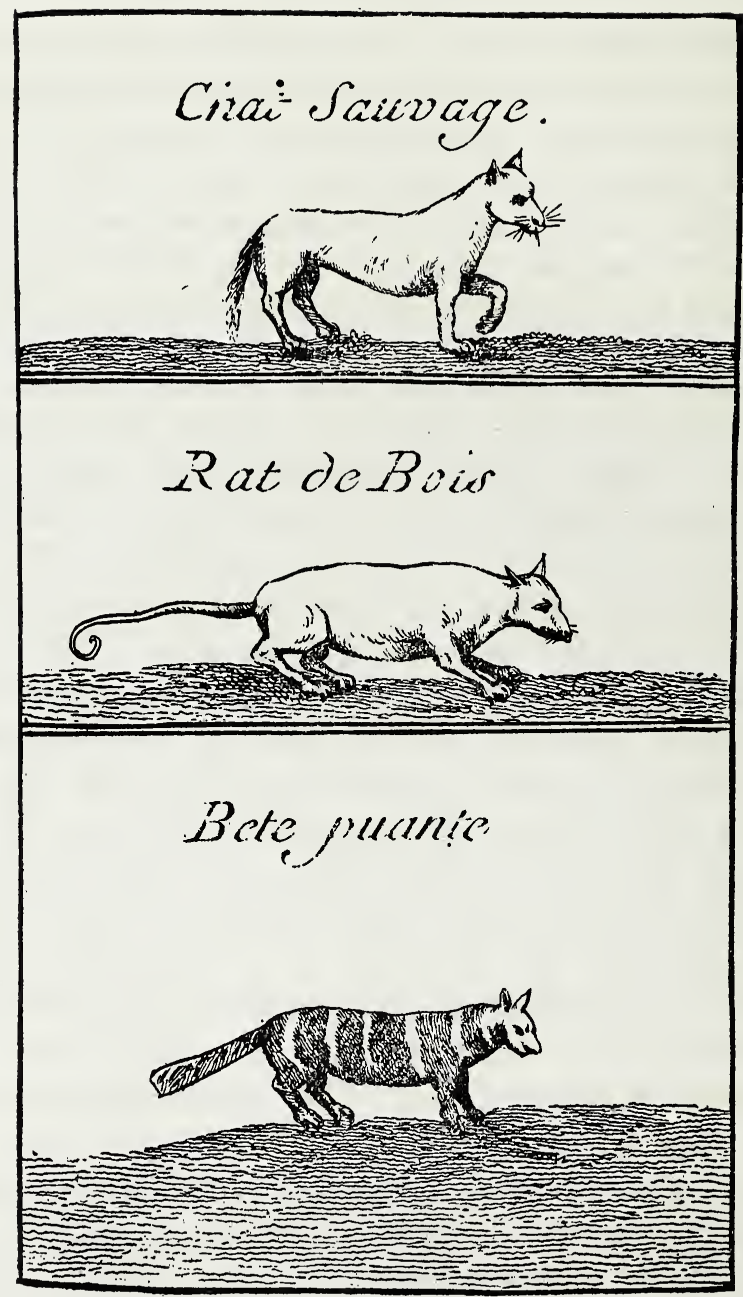

TOP: Wild Cat-MIDDLE: OpossumВоттом: Skunk

tiger left him. The next time he seized a pig; but this I likewise rescued, and his claws had gone no deeper than the fat. This animal is not more carnivorous than fearful; he flies at the sight of a man, and makes off with greater speed, if you shout and halloo as he runs.

The Cat-a-mount is a kind of wild cat, as high as the tiger, but not so thick, and his skin is extremely beautiful. $\mathrm{He}$ is a great destroyer of poultry, but fortunately his species is rare. 
Foxes are so numerous, that upon the woody heights you frequently see nothing but their holes. As the woods afford them plenty of game, they do not molest the poultry, which are always allowed to run at large. The foxes are exactly shaped like ours, but their skin is much more beautiful. Their hair is fine and thick, of a deep brown colour, and over this rise several long silver-coloured hairs, which have a fine effect.

The Wild Cat has been improperly so called by the first French settlers in Louisiana; for it has nothing of the cat but its nimble activity, and rather resembles a monkey. It is not above eight or ten inches high, and about fifteen long. Its head is like that of a fox; it has long toes, but very short claws, not made for seizing game; accordingly it lives upon fruit, bread, and other such things. This animal may be tamed, and then becomes very frolicksome and full of tricks. The hair of those that are tame is grey; but of the wild is reddish; neither of them is so beautiful as that of the fox; it grows very fat, and its flesh is good to eat. I. shall not describe the real wild cat, as it is entirely like ours.

The Rabbit is extremely common over all Louisiana; it is particular in this, that its pile is like that of the hare, and it never burrows. Its flesh is white and delicate, and has the usual taste, without any rankness. There is no other kind of rabbit or hare, if you please to call it, in all the colony, than that above described.

The Wood-Rat has the head and tail of a common rat, but has the bulk and length of a cat. Its legs are short, its paws long, and its toes are armed with claws: its tail is almost without hair, which serves for hooking itself to any thing; for when you take hold of it by that part, it immediately twists itself round your finger. Its pile is grey, and though very fine, yet is never smooth. The women among the natives spin it and dye it red. It hunts by night, and makes war upon the poultry, only sucking their blood and leaving their flesh. It is very rare to see any creature walk so slow; and I have often catched them when walking my ordinary pace. When he sees himself upon the point of being caught, instinct prompts him to counterfeit being dead; and in this he perseveres with such 
constancy, that though laid on a hot gridiron, he will not make the least sign of life. He never moves, unless the person go to a distance or hide himself, in which case he endeavors as fast as possible to escape into some hole or bush.

When the she-one is about to litter, she chooses a place in the thick bushes at the foot of a tree, after which she and the male crop a great deal of fine dry grass, which is loaded upon her belly, and then the male drags her and her burden by the tail to the littering-place. She never quits her young a moment; but when she is obliged to change her lodging, carries them with her in a pouch or double skin that wraps round her belly, and there they may sleep or suck at their ease. The two sides of this pouch lap so close that the joining can hardly be observed; nor can they be separated without tearing the skin. If the she-one be caught carrying her young thus with her, she will suffer herself to be roasted alive, without the least sign of life, rather than open the pouch and expose her young ones. The flesh of this animal is very good, and tastes somewhat like that of a sucking pig, when it is first broiled, and afterwards roasted on the spit.

The Pole-cat or Skunk is about the size of a kitten eight months old. The male is of a beautiful black, but the female has rings of white intermixed with the black. Its ear and its paw are like that of a mouse, and it has a very lively eye. I suppose it lives upon fruits and seeds. It is most justly called. the Stinking Beast, for its odour is so strong, that it may be pursued upon the track twenty-four hours after it has passed. It goes very slow, and when the hunter approaches it, it squirts out far and wide such a stinking urine, that neither man nor beast can hardly approach it. A drop of this creature's blood, and probably some of its urine, having one day fallen upon my coat when I was hunting, I was obliged as fast as possible to go home and change my cloaths; and before I could use my coat, it was scoured and exposed for several days to the dew.

The Squirrels of Louisiana are like those of France, excepting one kind, which are called Flying-Squirrels, because they leap from one tree to another, though the distance between them be twenty-five or thirty feet. It is about the size of a 
rat, and of a deep ash-colour. Its two fore-legs are joined to its two hind-legs by two membranes, so that when it leaps it seems to fly, though it always leaps somewhat downwards. This animal may be very easily tamed; but even then it is best to chain it. There is another sort, not much bigger than a mouse, and of a bright bay-colour. These are so familiar that they will come out of the woods, will enter the houses, and sit within two yards of the people of the house, if they do not make any motion; and there they will feed on any maiz within their reach. I never was so well diverted in my life with the frolics of any animal, as I have been with the vivacity and attitudes of this little squirrel.

The Porcupine is large and fine of this kind; but as he lives only upon fruit, and loves cold, is most common about the river Illinois, where the climate is somewhat cold, and there is plenty of wild fruits. The skin, when stripped of the quills, is white and brown. The natives dye part of the white, yellow and red, and the brown they dye black. They have likewise the art of splitting the skin, and applying it to many curious works, particularly to trim the edges of their deer-skin, and to line small bark-boxes, which are very neat.

The Hedge-hog of Louisiana is in every respect the same with that of Europe.

I shall not enlarge upon the Beavers, which are universally known, from the many descriptions we have of them.

The Otters are the same with those of France, and there are but few of them to be seen.

Some Turtle are seen in this country; but very rarely. In the many hundred leagues of country that I have passed over, I have hardly seen above a hundred.

Frogs are very common, especially in Lower Louisiana, notwithstanding the great number of snakes that destroy them. There are some that grow very large, sometimes above a foot and a half long, and astonish strangers at first by their croaking especially if they are in a hollow tree.

The Crocodile is very common in the river Missisippi. Although this amphibious animal be almost as well known as 
those I have just mentioned, I cannot however omit taking some notice of it. Without troubling the reader with a description of it, which he will meet with every where, I shall observe that it shuns the banks of the river frequented by men. It lays its eggs in the months of May, when the sun is already hot in that country, and it deposits them in the most concealed place it can find among grass exposed to the heats of the south. The eggs are about the size of those of a goose, but longer in proportion. Upon breaking them you will find hardly any thing but white, the yolk being about the size of that of a young hen. I never saw any that were new hatched. The smallest I ever met with, which I concluded to be about three months old, was as long as a middle-sized eel, and an inch and a half thick. I have killed one nineteen feet long, and three feet and a half in its greatest breadth. A friend of mine killed one twenty-two feet long, and the legs of both these, which on land seemed to move with great difficulty, were not above a foot in length. But however sluggish they be on land, in the water they move with great agility.

This animal has his body always covered with slime, which is the case with all fishes that live in muddy waters. When he comes on shore his track is covered with that slime, as his belly trails on the ground, and this renders the earth very slippery in that part, especially as he returns by the same path to the water. He never hunts the fish upon which he subsists; but places himself in ambuscade, and catches them as they pass. For that purpose he digs a hole in the bank of the river, below the surface of the water, where the current is strong, having a small entrance, but large enough within to turn himself round in. The fish, which are fatigued with the strong current, are glad to get into the smooth water in that corner, and there they are immediately seized by the crocodile.

I shall not contradict the accounts of venerable antiquity about the crocodiles of the Nile, who fall upon men and devour them; who cross the roads, and make a slippery path upon them to trip passengers, and make them slide into the river; who counterfeit the voice of an infant, to draw children into their snares; neither shall I contradict the travellers who have 
confirmed those stories from mere hearsays. But as I profess to speak the truth, and to advance nothing but what I am certain of from my own knowledge, I may safely affirm that the crocodiles of Louisiana are doubtless of another species than those of other countries. In fact, I never heard them imitate the cries of an infant, nor is it at all probable that they can counterfeit them. Their voice is as strong as that of a bull. It is true they attack men in the water, but never on land, where they are not at all formidable. Besides, there are nations that in great part subsist upon this animal, which is hunted out by the fathers and mothers, and killed by the children. What can we then believe of those stories that have been told us of the crocodile? I myself killed all that ever I met of them; and they are so much the less to be dreaded, in that they can neither run nor rise up against a man. In the water indeed, which is their favourite element, they are dangerous; but in that case it is easy to guard against them.

The largest of all the reptiles of Louisiana, is the RattleSnake: some of them have been seen fifteen inches thick, and long in proportion; but this species is naturally shorter in proportion to their thickness than the other kinds of serpents. This serpent gets its name from several hollow knots at its tail, very thin and dry, which make a rattling noise. These knots, though inserted into each other, are yet quite detached, and only the first of them is fastened to the skin. The number of the knots, it is said, marks the age of the serpent, and I am much inclined to believe it; for as I have killed a great number of them, I always observed, that the longer and thicker the serpent was, it had the more knots. Its-skin is almost black; but the lower part of its belly is striped black and white.

As soon as it hears or sees a man, it rouses itself by shaking its tail, which makes a rattling noise that may be heard at several paces distance, and gives warning to the traveller to be upon his guard. It is much to be dreaded when it coils itself up in a spiral line, for then it may easily dart upon a man. It shuns the habitations of men, and by a singular providence, wherever it retires to, there the herb which cures its bite, is likewise to be found. 


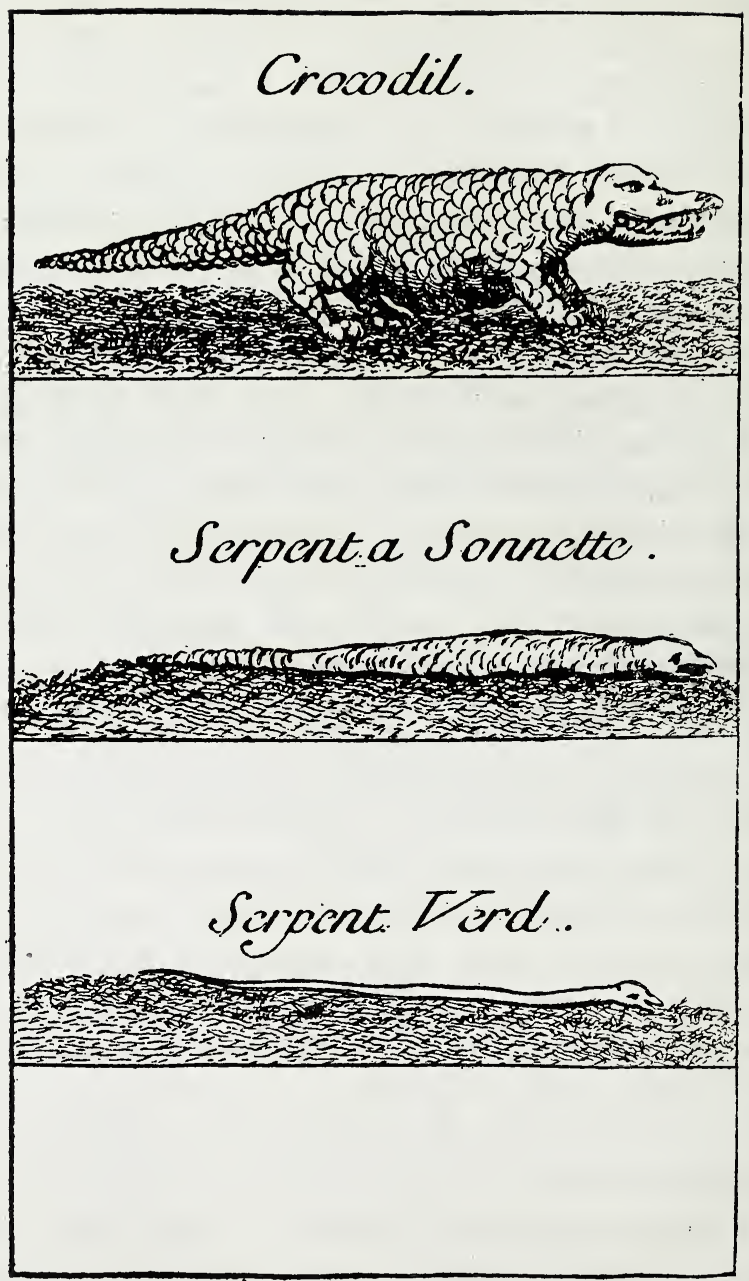

TOP: Alligator-MIDDL: Rattle SnakeBоттом: Green Snake

There are several other kinds of serpents to be seen here, some of which resemble those of France, and attempt to slip into the hen-houses to devour the eggs and new-hatched chickens. Others are green, about two feet long, and not thicker than a goose-quill; they frequent the meadows, and may be seen running over the spires of grass, such is their lightness. and nimbleness. 
Vipers are very rare in Lower Louisiana, as that reptile loves stoney grounds. In the highlands they are now-and-then to met with, and there they quite resemble ours.

Lizards are very common: there is a small kind of these that are called Cameleons, because they change their colour according to that of the place they pass over*.

Among the spiders of Louisiana there is one kind that will appear very extraordinary. It is as large, but rather longer than a pigeon's egg, black with gold-coloured specks. Its claws are pierced through above the joints. It does not carry its eggs like the rest, but encloses them in a kind of cup covered with its silk. It lodges itself in a kind of nut made of the same silk, and hung to the branches of the trees. The web which this insect weaves is so strong, that it not only stops birds, but cannot even be broken by men without a considerable effort.

I never saw any Moles in Louisiana, nor heard of any being seen by others.

* When the Cameleon is angry, a nerve rises arch-wise from his mouth to the middle of his throat; and the skin which covers it is so stretched as to remain red, whatever colour the rest of the body be. He never does any hurt, and always runs away when observed.

\section{CHAPTER VII.}

\section{Of Birds, and Flying Insects.}

$\mathbf{B}^{\text {IRDS }}$ are so very numerous in Louisiana, that if all the different kinds of them were known, which is far from being the case at present, the description of them alone would require an entire volume. I only undertake the description of all those which have come within my knowledge, the number of which, I am persuaded, will be sufficient to satisfy the curious reader.

The Eagle, the king of birds, is smaller than the eagle of the Alps; but he is much more beautiful, being entirely white, excepting only the tips of his wings, which are black. As he is also very rare, this is another reason for heightening his value to the natives, who purchase at a great price the large 
feathers of his wings, with which they ornament the Calumet, or Symbol of Peace, as I have elsewhere described.

When speaking of the king of birds, I shall take notice of the Wren, called by the French Roitelet (Petty King) which is the same in Louisiana as in France. The reason of its name in French will plainly enough appear from the following history. A magistrate, no less remarkable for his probity than for the rank he holds in the law, assured me that, when he was at Sables d'Olonne in Poitou, on account of an estate which he had in the neighbourhood of that city, he had the curiosity to go and see a white eagle which was then brought from America. After he had entered the house a wren was brought, and let fly in the hall where the eagle was feeding. The wren perched upon a beam, and was no sooner perceived by the eagle, than he left off feeding, flew into a corner, and hung down his head. The little bird, on the other hand, began to chirp and appear angry, and a moment after flew upon the neck of the eagle, and pecked him with the greatest fury, the eagle all the while hanging his head in a cowardly manner, between his feet. The wren, after satisfying its animosity, returned to the beam.

The Falcon, the Hawk, and the Tassel are the same as in France; but the falcons are much more beautiful than ours.

The Carrion-Crow, or Turky Bustard, is of the size and shape of a Turky-cock; his head is covered with red flesh, and his plumage is black: he has a hooked beak, but his toes are armed with very small talons, and are therefore very improper for seizing live game, which indeed he does not chuse to attack, as his want of agility prevents him from darting upon it with the rapidity of a bird of prey. Accordingly he lives only upon the dead beasts that he happens to meet with, and yet notwithstanding this kind of food he smells of musk. Several people maintain, that the Carrion-Crow, or Carancro, is the same with our Vulture. The Spaniards forbid the killing of it under pain of corporal punishment; for as they do not use the whole carcase of the buffaloes which they kill, those birds eat what they leave, which otherwise, by rotting on the ground, would, according to them, infect the air. 
The Cormorant is shaped very much like a duck, but its plumage is different and much more beautiful. This bird frequents the shores of the sea and of lakes, but rarely appears in rivers. Its usual food is fish; but as it is very voracious, it likewise eats dead flesh; and this it can tear to pieces by means of a notch in its bill, which is about the size of that of a duck.

The Swan of Louisiana are like those of France, only they are larger. However, notwithstanding their bulk and their weight, they often rise so high in the air, that they cannot be distinguished but by their shrill cry. Their flesh is very good to eat, and their fat is a specific against cold humours. The natives set a great value upon the feathers of the Swan. Of the large ones they make the diadems of their sovereigns, hats, and other ornaments; and they weave the small ones as the peruke-makers weave hair, and make coverings of them for their noble women. The young people of both sexes make tippets of the skin, without stripping it of its down.

The Canada-Goose is a water-fowl, of the shape of a goose; but twice as large and heavy. Its plumage is ash-coloured; its eyes are covered with a black spot; its cries are different from those of a goose, and shriller; its flesh is excellent.

The Pelican is so called from its large head, its large bill, and above all for its large pouch, which hangs from its neck, and has neither feather nor down. It fills this pounch with fish, which it afterwards disgorges for the nourishment of its young. It never removes from the shores of the sea, and is often killed by sailors for the sake of the pouch, which when dried serves them as a purse for their tobacco.

The Geese are the same with the wild geese of France. They abound upon the shores of the sea and of lakes, but are rarely seen in rivers.

In this country there are three kinds of Ducks; first, the Indian Ducks, so called because they came originally from that country. These are almost entirely white, having but a very few grey feathers. On each side of their head they have flesh of a more lively red than that of the Turky-cock, and they are larger than our tame ducks. They are as tame as those of 


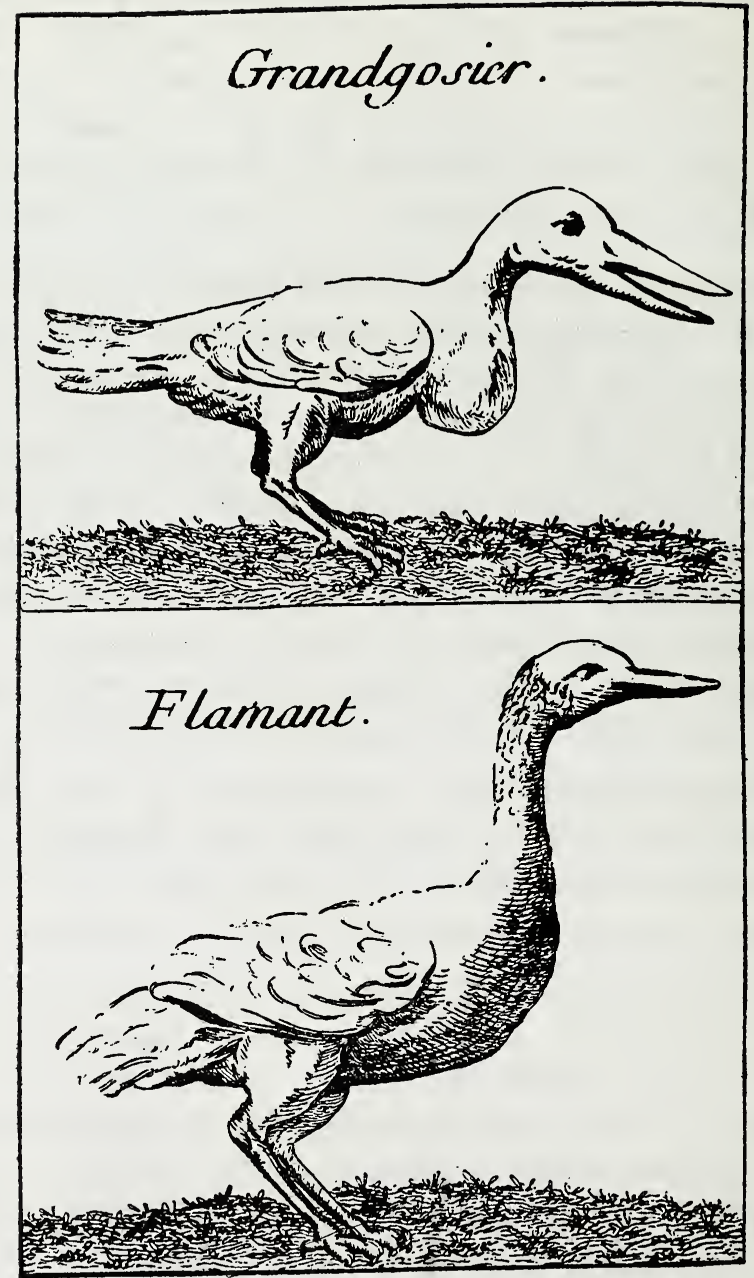

ToP: Pelican-Воттом: Wood Stock

Europe, and their flesh when young is delicate, and of a fine flavour. The Wild Ducks are fatter, more delicate, and of better taste than those of France; but in other respects they are entirely the same. For one you see in France you may here count a thousand. The Perching-Ducks, or Carolina SummerDucks, are somewhat larger than our teals. Their plumage is quite beautiful, and so changeable that no painting can imitate it. Upon their head they have a beautiful tuft of the most 
lively colours, and their red eyes appear like flames. The natives ornament their calumets or pipes with the skin of their neck. Their flesh is very good, but when it is too fat it tastes oily. These ducks are to be met with the whole year round; they perch upon the branches of trees, which the others do not, and it is from this they have their name.

The Teal are found in every season; and they differ nothing from those of France but in having a finer relish.

The Divers of Louisiana are the same with those of France: they no sooner see the fire in the pan, than they dive so suddenly that the shot cannot touch them, and they are therefore called Lead-Eaters.

The Saw-bill has the inside of its beak indented like the edge of a saw: it is said to live wholly upon shrips, the shells of which it can easily break.

The Crane is a very common water-fowl; it is larger than a turkey, very lean, and of an excellent taste. It eats somewhat like beef, and makes very good soup.

The Flamingo has only a little down upon its head; its plumage is grey, and its flesh good.

The Spatula has its name from the form of its bill, which is about seven or eight inches long, an inch broad towards the head, and two inches and a half towards the extremity; it is not quite so large as a wild goose; its thighs and legs are about the height of those of a turkey. Its plumage is rose-coloured, the wings being brighter than any other part. This is a waterfowl, and its flesh is very good.

The Heron of Louisiana is not in the least different from that of Europe.

The Egret, or White Heron, is so called from tufts of feathers upon the wings near the body, which hinder it from flying high; it is a water-fowl with white plumage; but its flesh tastes very oily.

The Bec-croche, or Crook-bill, has indeed a crooked bill, with which it seizes the cray-fish upon which it subsists. Its 


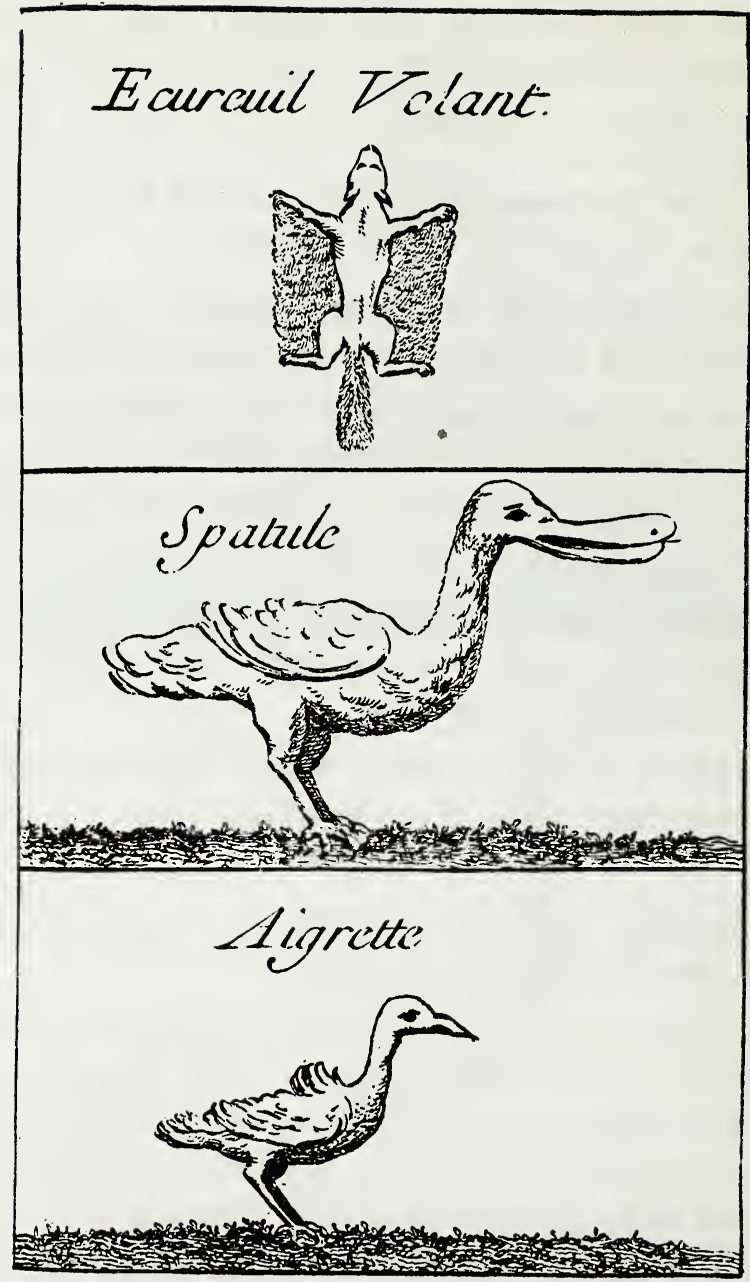

TOP: Flying Squirrel-MIDDLE: Roseate Spoonbill-Bоттом: Snowy Heron

flesh has that taste, and is red. Its plumage is a whitish grey; and it is about the size of a capon.

The Indian Water-Hen, and the Green-Foot, are the same as in France.

The Hatchet-Bill is so called on account of its bill, which is red, and formed like the edge of an ax. Its feet are also of a beautiful red, and it is therefore often called Red-Foot. As: 
it lives upon shell-fish, it never removes from the sea-coast, but upon the approach of a storm, which is always sure to follow its retiring into the inland parts.

The King-Fisher excels ours in nothing but in the beauty of its plumage, which is as various as the rainbow. This bird, it is well known, goes always against the wind; but perhaps few people know that it preserves the same property when it is dead. I myself hung a dead one by a silk thread directly over a sea-compass, and I can declare it as a fact, that the bill was always turned towards the wind.

The Sea-Lark and Sea-Snipe never quit the sea; their flesh may be eat, as it has very little of the oily taste.

The Frigate-Bird is a large bird, which in the day-time keeps itself in the air above the shore of the sea. It often rises very high, probably for exercise; for it feeds upon fish, and every night retires to the coast. It appears larger than it really is, as it is covered with a great many feathers of a grey colour. Its wings are very long, its tail forked, and it cuts the air with great swiftness.

The Draught-Bird is a large bird, not much unlike the Frigate-Bird, as light, but not so swift. The under-part of its plumage is chequered brown and white, but the upper-part is of greyish brown.

The Fool is of a yellowish colour, and about the size of a hen; it is so called, because it will suffer a man to approach it so near as to seize it with his hand: but even then it is too soon to cry victory; for if the person who seizes it does not take the greatest precaution, it will snap off his finger at one bite.

When those three last birds are observed to hover very low over the shore, we may most certainly expect an approaching storm. On the other hand, when the sailors see the Halcyons behind their vessel, they expect and generally meet with fine weather for some days.

Since I have mentioned the Halcyon, I shall here describe it. It is a small bird, about the size of a swallow, but its beak 
is longer, and its plumage is violet-coloured. It has two streaks of a yellowish brown at the end of the feathers of its wings, which when it sits appear upon its back. When we left Louisiana, near an hundred halcyons followed our vessel for near three days: they kept at the distance of about a stonecast, and seemed to swim, yet I could never discover that their feet were webbed, and was therefore greatly surprised. They probably live upon the small insects that drop from the outside of the vessel when sailing; for they now-and-then dived, and came up in the same place. I have some suspicion that, by keeping in the wake of the ship, they float after it without swimming; for when they happened to be out of the wake of the ship, they were obliged to fly, in order to come up with the ship again. This bird is said to build its nest of the glutinous froth of the sea close upon the shore, and to launch it when a land breeze arises, raising one of its wings in the form of a sail, which receiving the wind, helps to carry it out to sea.

I shall now proceed to speak of the fowls which frequent the woods, and shall begin with the Wild-Turky, which is very common all over the colony. It is finer, larger, and better than that in France. The feathers of the turky are of a duskish grey, edged with a streak of gold colour, near half an inch broad. In the small feathers the gold-coloured streak is not above one tenth of an inch broad. The natives make fans of the tail, and of four tails joined together, the French make an umbrella. The women among the natives weave the feathers as our peruke-makers weave their hair, and fasten them to an old covering of bark, which they likewise line with them, so that it has down on both sides. Its flesh is more delicate, fatter, and more juicy than that of ours. They go in flocks, and with a dog one may kill a great many of them. I never could procure any of the turky's eggs, to try to hatch them, and discover whether they were as difficult to bring up in this country as in France, since the climate of both countries is almost the same. My slave told me, that in his nation they brought up the young turkies as easily as we do chickens.

The Pheasant is the most beautiful bird that can be painted, and in every respect entirely like that of Europe. 


\section{Bec.croche.}

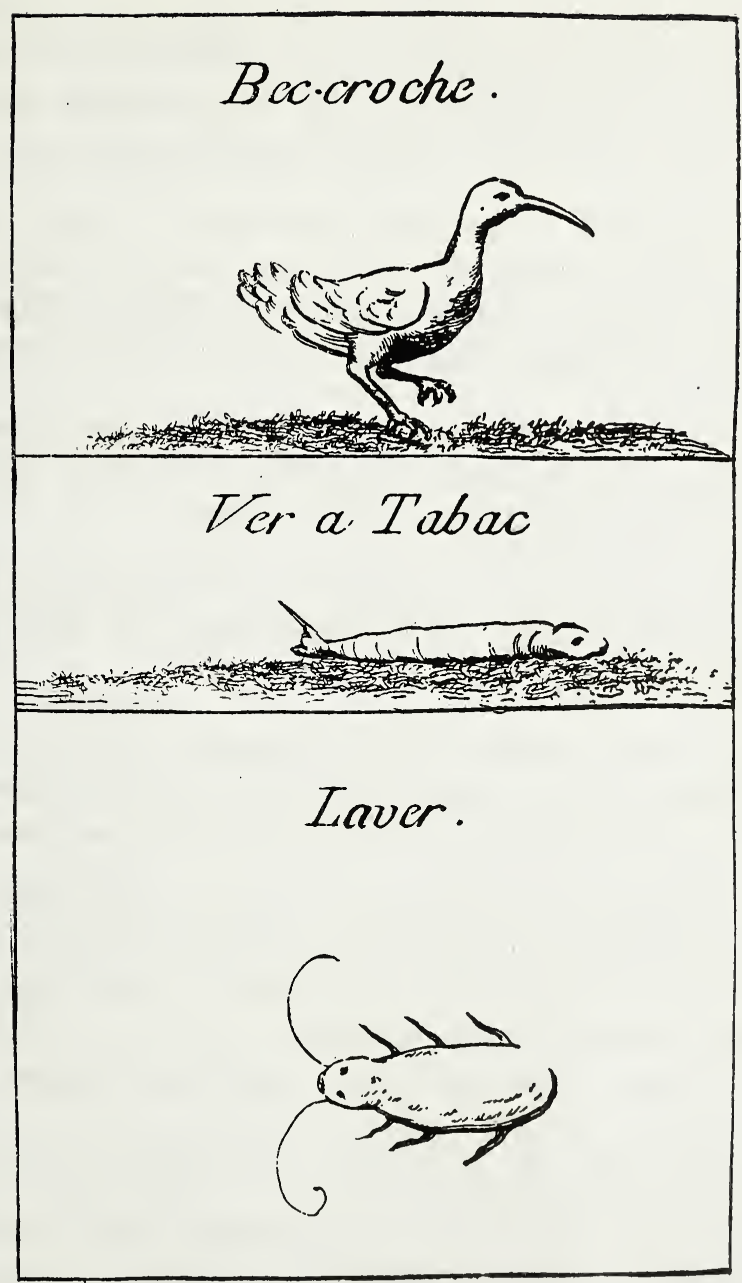

ToP: White Ibis-MIDDLE: Tobacco WormBotтом: Cock Roach

Their rarity, in my opinion, makes them more esteemed than they deserve. I would at any time prefer a slice off the fillet of a buffalo to any pheasant.

The Partridges of Louisiana are not larger than a woodpigeon. Their plumage is exactly the same with that of our grey partridges; they have also the horse-shoe upon the breast; they perch upon trees, and are seldom seen in flocks. Their 
cry consists only of two strong notes, somewhat resembling the name given them by the natives, who call them Ho-ouy. Their flesh is white and delicate, but, like all the other game in this country, it has no fumet, and only excels in the fine taste.

The Woodcock is very rare, because it is only to be met with in inhabited countries. It is like that of France; its flesh is white, but rather plumper and more delicate than that of ours, which is owing to the plenty and goodness of its fruit.

The Snipe is much more common than the woodcock, and in this country is far from being shy. Its flesh is white, and of a much better relish than that of ours.

I am of opinion that the Quail is very rare in Louisiana; I have sometimes heard it, but never saw it, nor know any Frenchman that ever did.

Some of our colonists have thought proper to give the name of Ortolan to a small bird which has the same plumage, but in every other respect does not in the least resemble it.

The Corbijeau is as large as the woodcock, and very common. Its plumage is varied with several shady colours, and is different from that of the woodcock; its feet and beak are also longer, which last is crooked and of a reddish yellow colour; its flesh is likewise firmer and better tasted.

The Parroquet of Louisiana is not quite so large as those that are usually brought to France. Its plumage is usually of a fine sea-green, with a pale rose-coloured spot upon the crown, which brightens into red towards the beak, and fades off into green towards the body. It is with difficulty that it learns to speak, and even then it rarely practices it, resembling in this the natives themselves, who speak little. As a silent parrot would never make its fortune among our French ladies, it is doubtless on this account that we see so few of these in France.

The Turtle-Dove is the same with that of Europe, but few of them are seen here.

The Wood-Pigeons are seen in such prodigious numbers, that I do not fear to exaggerate, when I affirm that they some- 
times cloud the sun. One day on the banks of the Missisippi I met with a flock of them which was so large, that before they all passed, I had leisure to fire with the same piece four times at them. But the rapidity of their flight was so great, that though I do not fire ill, with my four shots I brought down but two.

These birds come to Louisiana only in the winter, and remain in Canada during the summer, where they devour the corn, as they eat the acorns in Louisiana. The Canadians have used every art to hinder them from doing so much mischief, but without success. But if the inhabitants of those colonies were to go a fowling for those birds in the manner that I have done, they would insensibly destroy them. When they walk among the high forest trees, they ought to remark under the trees the largest quantity of dung is to be seen. Those trees being once discovered, the hunters ought to go out when it begins to grow dark, and carry with them a quantity of brimstone which they must set fire to in so many earthen plates placed at regular distances under the trees. In a very short time they will hear a shower of wood-pigeons falling to the ground, which, by the light of some dried canes, they may gather into sacks, as soon as the brimstone is extinguished.

I shall here give an instance that proves not only the prodigious number of those birds, but also their singular instinct. In one of my journeys at land, when I happened to be upon the bank of the river, I heard a confused noise which seemed to come along the river from a considerable distance below us. As the sound continued uniformly I embarked, as fast as I could, on board the pettyaugre, with four other men, and steered down the river, keeping in the middle, that I might go to any side that best suited me. But how great was my surprise when I approached the place from whence the noise came, and observed it to proceed from a thick short pillar on the bank of the river. When I drew still nearer to it, I perceived that it was formed by a legion of wood-pigeons, who kept continually flying up and down successively among the branches of an ever-green oak, in order to beat down the acorns with their wings. Every now and then some alighted to eat the 
acorns which they themselves or the others had beat down; for they all acted in common, and eat in common; no avarice nor private interest appearing among them, but each labouring as much for the rest as for himself.

Crows are common in Louisiana, and as they eat no carrion their flesh is better tasted than that of the crows of France. Whatever their appetite may be, they dare not for the carrion crow approach any carcass.

I never saw any Ravens in this country, and if there be any they must be very rare.

The Owls are larger and whiter than in France, and their cry is much more frightful. The Little Owl is the same with ours, but much more rare. These two birds are more common in Lower Louisiana than in the higher.

The Magpye resembles those of Europe in nothing but its cry; it is more delicate, is quite black, has a different manner of flying, and chiefly frequents the coasts.

The Blackbirds are black all over, not excepting their bills nor their feet, and are almost as large again as ours. Their notes are different, and their flesh is hard.

There are two sorts of Starlings in this country; one grey and spotted, and the other black. In both the tip of the shoulder is of a bright red. They are only to be seen in winter; and then they are so numerous, that upwards of three hundred of them have been taken at once in a net. A beaten path is made near a wood, and after it is cleaned and smoothed, it is strewed with rice. On each side of this path is stretched a long narrow silken net, with very small meshes, and made to turn over at once by strings fastened to the stick that stretches the end of it. The starlings no sooner alight to pick up the grain, than the fowler, who lies concealed with the strings in his hand, pulls the net over them.

The Wood-pecker is much the same as in France; but here there are two kinds of them; one has grey feathers spotted with black; the other has the head and the neck of a bright red, and the rest of the body as the former. This bird lives upon the 
worms which it finds in rotten wood, and not upon ants, as a modern author would have us believe, for want of having considered the nature of the things which he relates. The bird, when looking for its food, examines the trunks of trees that have lost their bark; it clasps by its feet with its belly close to the tree, and hearkens if it can hear a worm eating the wood; in this manner it leaps from place to place upon the trunk till it hears a worm, then it pierces the wood in that part, pricks the worms with its hard and pointed tongue, and draws it out. The arms which nature has furnished it with are very proper for this kind of hunting; its claws are hard and very sharp; its beak is formed like a little ax, and is very hard; its neck is long and flexible, to give proper play to its beak; and its hard tongue, which it can extend three or four inches, has a most sharp point with several beards that help to hold the prey.

The Swallows of this country have that part yellow which ours have white, and they, as well as the martins, live in the woods.

The Nightingale differs in nothing from ours in respect to its shape or plumage, unless that it has the bill a little longer. But in this it is particular that it is not shy, and sings through the whole year, though rarely. It is very easy to entice them to your roof, where it is impossible for the cats to reach them, by laying something for them to eat upon a lath, with a piece of the shell of a gourd which serves to hold their nest. You may in that case depend upon their not changing their habitation.

The Pope is a bird that has a red and black plumage. It has got that name perhaps because its colour makes it look somewhat old, and none but old men are promoted to that dignity; or because its notes are soft, feeble, and rare; or lastly, because they wanted a bird of that name in the colony, having two other kinds named cardinals and bishops.

The Cardinal owes its name to the bright red of the feathers, and to a little cowl on the hind part of the head, which resembles that of the bishop's ornament, called a camail. It is as large as a black-bird, but not so long. Its bill and toes are 
large, strong, and black. Its notes are so strong and piercing that they are only agreeable in the woods. It is remarkable for laying up its winter provision in the summer, and near a Paris bushel of maiz has been found in its retreat, artfully covered, first with leaves and then with small branches, with only a little opening for the bird itself to enter.

The Bishop is a bird smaller than the linnet; its plumage is a violet-coloured blue, and its wings, which serve it for a cope, are entirely violet-colour. Its notes are so sweet, so variable, and tender, that those who have once heard it, are apt to abate in their praises of the nightingale. I had such great pleasure in hearing this charming bird, that I left an oak standing very near my apartment, upon which he used to come and perch, though I very well knew, that the tree, which stood single, might be overturned by a blast of wind, and fall upon my house to my great loss.

The Humming-Bird is not larger even with its feathers than a large beetle. The colour of its feathers is variable, according to the light they are exposed in; in the sun they appear like enamel upon a gold ground, which delights the eyes. The longest feathers of the wings of this bird are not much more than half an inch long; its bill is about the same length, and pointed like an awl; and its tongue resembles a sowing-needle; its feet are like those of a large fly. Notwithstanding its little size, its flight is so rapid, that it is always heard before it be seen. Although like the bee it sucks the flowers, it never rests upon them, but supports itself upon its wings, and passes from one flower to another with the rapidity of lightening. It is a rare thing to catch a humming-bird alive; one of my friends however had the happiness to catch one. He had observed it enter the flower of a convolvulus, and as it had quite buried itself to get at the bottom, he ran forwards, shut the flower, cut it from the stalk, and carried off the bird a prisoner. He could not however prevail upon it to eat, and it died four days after.

The Troniou is a small bird about the size of a sparrow; its plumage is likewise the same; but its beak is slenderer. Its notes seem to express its name. 
The French settlers raise in this province turkies of the same kind with those of France, fowls, capons, \&c. of an excellent taste. The pigeons for their fine flavour and delicacy are preferred by Europeans to those of any other country. The Guinea fowl is here delicious.

In Louisiana we have two kinds of Silk-worms; one was brought from France, the other is natural to the country. I shall enlarge upon them under the article of agriculture.

The Tobacco-worm is a caterpillar of the size and figure of a silk-worm. It is of a fine sea-green colour, with rings of a silver colour; on its rump it has a sting near a quarter of an inch long. These insects quickly do a great deal of mischief, therefore care is taken every day, while the tobacco is rising, to pick them off and kill them.

In summer Caterpillars are sometimes found upon the plants, but these insects are very rare in the colony. Glowworms are here the same as in France.

Butterflies are not near so common as in France; the consequence of there being fewer caterpillars; but they are of incomparable beauty, and have the most brilliant colours. In the meadows are to be seen black grasshoppers, which almost always walk, rarely leap, and still seldomer fly. They are about the size of a finger or thum, and their head is shaped somewhat like that of a horse. Their four small wings are of a most beautiful purple. Cats are very fond of grasshoppers.

The Bees of Louisiana lodge in the earth, to secure their honey from the ravages of the bears. Some few indeed build their combs in the trunks of trees, as in Europe; but by far the greatest number in the earth in the lofty forests, where the bears seldom go.

The Flies are of two kinds, one a yellowish brown, as in France, and the other black.

The Wasps in this country take up their abode near the houses where they smell victuals. Several French settlers endeavored to root them out of their neighbourhood; but I acted otherwise; for reflecting, that no flies are to be seen where the 
wasps frequent, I invited them by hanging up a piece of flesh in the air.

The quick-stinger is a long and yellowish fly, and it receives its name from its stinging the moment it lights. The common flies of France are very common also in Louisiana.

The Cantharides, or Spanish flies, are very numerous, and larger than in Europe; they are of such an acid nature, that if they but slightly touch the skin as they pass, a pretty large blister instantly rises. These flies live upon the leaves of the oak.

The Green-flies appear only every other year, and the natives superstitiously look upon their appearance as a presage of a good crop. It is a pity that the cattle are so greatly molested by them, that they cannot remain in the fields; for they are extremely beautiful and twice as large as bees.

Fire flies are very common; when the night is serene they are so very numerous, that if the light they dart out were constant, one might see as clearly as in fine moonshine.

The Fly-ants, which we see attach themselves to the flower of the acacia, and which disappear when that flower is gone. do not proceed from the common ants. The fly ants, though shaped like the other kind, are however longer and larger. They have a square head; their colour is a brownish red bordered with black; they have four red and grey wings, and fly like common flies, which the other ants do not even when they have wings.

The Dragon-flies are pretty numerous; they do not want to destroy them because they feed upon moskitos, which is one of the most troublesome kind of insects.

The Moskitos are famous all over America, for their multitude, the troublesomeness of their buzzing and the venom of their stings, which occasion an insupportable itching, and often form so many ulcers, if the person stung does not immediately put some spittle on the wound. In open places they are less tormenting; but still they are troublesome; and the best way of driving them out of the houses is to burn a little brimstone in 
the mornings and evenings. The smoke of this infallibly kills them, and the smell keeps others away for several days. An hour after the brimstone has been burnt, the apartments may be safely entered into by men.

By the same means we may rid ourselves of the flies and moskitos, whose sting is so painful and so frequent during the short time they fly about; for they do not rise till about sunset, and they retire at night. This is not the case with the Burning-fly. These, though not much larger than the point of a pin, are insupportable to the people who labour in the fields. They fly from sun-rising to sun-setting, and the wounds they give burn like fire.

The Lavert is an insect about an inch and a quarter long, a little more than a quarter broad, and a tenth part of an inch thick. It enters the houses by the smallest crevices and in the night-time it falls upon dishes that are covered even with a plate, which renders it very troublesome to those whose houses are only built of wood. Bue they are so relishing to the cats, that these last quit everything to fall upon them wherever they perceive them. When a new settler has once cleared the ground about his house, and is at some distance from the woods, he is quickly freed from them.

In Louisiana there are white ants, which seem to love dead wood. Persons who have been in the East-Indies have assured me, that they are quite like those which in that country are called cancarla, and that they would eat through glass, which I never had the experience of. There are in Louisiana, as in France, red, black, and flying ants. 


\section{CHAPTER VIII. \\ Of Fishes and Shell-Fish.}

THOUGH there is an incredible quantity of fishes in this country, I shall however be very concise in my account of them; because during my abode in the country they were not sufficiently known; and the people were not experienced enough in the art of catching them. The most of the rivers being very deep, and the Missisippi, as I have mentioned, being between thirty-eight and forty fathoms, from its mouth to the fall of St. Anthony, it may be easily conceived that the instruments used for fishing in France, cannot be of any use in Louisiana, because they cannot go to the bottom of the rivers, or at least so deep as to prevent the fish from escaping. The line therefore can be only used and it is with it they catch all the fish that are eaten by the settlers upon the river. I proceed to an account of those fish.

The Barbel is of two sorts, the large and the small. The first is about four feet long, and the smallest of this sort that is ever seen is two feet long, the young ones doubtless keeping at the bottom of the water. This kind has a very large head, and a round body, which gradually lessens toward the tail. The fish has no scales, nor any bones, excepting that of the middle: its flesh is very good and delicate, but in a small degree vary insipid, which is easily remedied; in other respects it eats very like the fresh cod of the country.

The small is from a foot to two in length. Its head is shaped like that of the other kind; but its body is not so round, nor so pointed at the tail.

The Carp of the river Missisippi is monstrous. None are seen under two feet long; and many are met with three and four feet in length. The carps are not so very good in the lower part of the river; but the higher one goes the finer they are, on account of the plenty of sand in those parts. A great number of carps are carried into the lakes that are filled by the overflowing of the river, and in those lakes they are found 


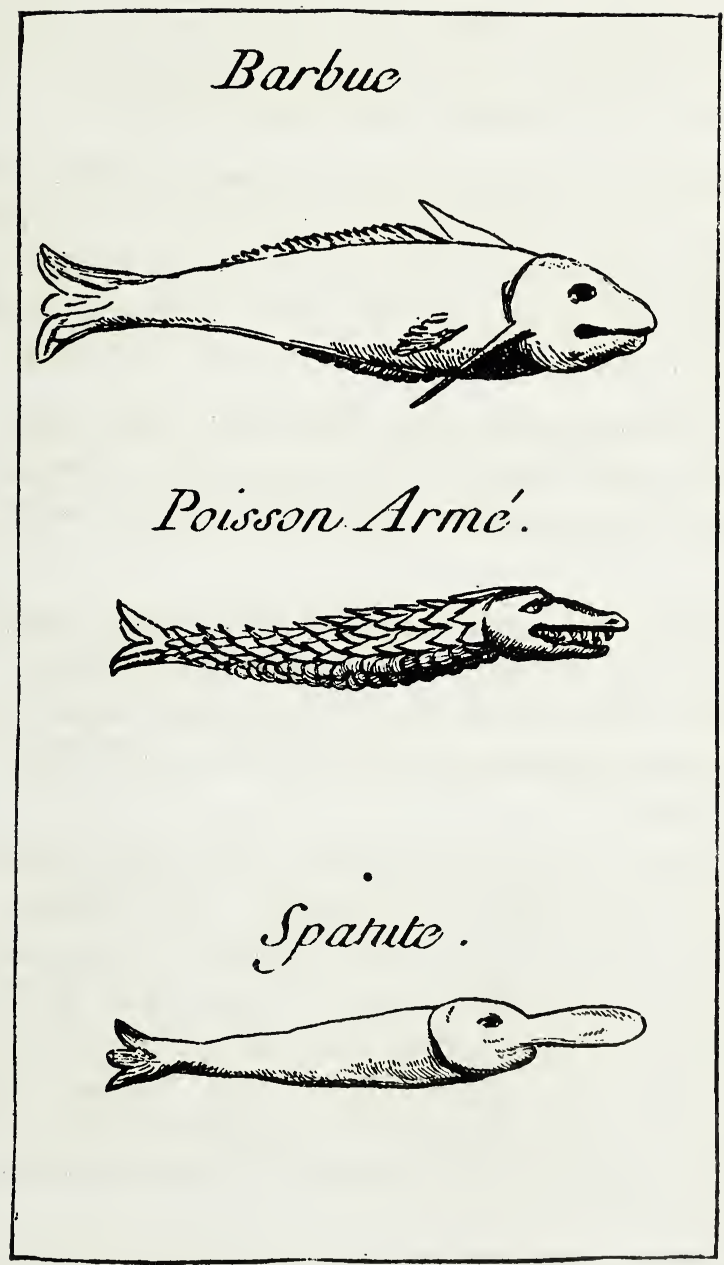

ToP: Cat Fish-MIDDLE: Gar FishВоттом: Spoonbill Catfish

of all sizes, in great abundance, and of a better relish than those of the river.

The Burgo-Breaker is an excellent fish; it is usually a foot and a foot and a half long: it is round, with gold-coloured scales. In its throat it has two bones with a surface like that of a file to break the shell-fish named Burgo. Though delicate, it is nevertheless very firm. It is best when not much boiled. 
The Ring-Skate is found in the river up as far as New Orleans, but no higher. It is very good, and no way tough. In other respects it is exactly like that of France.

The Spatula is so called, because from its snout a substance extends about a foot in length, in the form of an apothecary's Spatula. This fish, which is about two feet in length, is neither round or flat, but square, having at its sides and in the under part bones that form an angle like those of the back.

No Pikes are caught above a foot and a half long. As this is a voracious fish, perhaps the Armed-fish pursues it, both from jealousy and appetite. The pike, besides being small, is very rare.

The Choupic is a very beautiful fish; many people mistake it for the trout, as it takes a fly in the same manner. But it is very different from the trout, as it prefers muddy and dead water to a clear stream, and its flesh is so soft that it is only good when fried.

The Sardine or small Pilchard of the river Missisippi, is about three or four fingers in breadth, and between six and seven inches long; it is good and delicate. One year I salted about the quantity of forty pints of them, and all the French who eat of them acknowledged them to be Sardines from their flesh, their bones, and their taste. They appear only for a short season, and are caught by the natives, when swimming against the strongest current, with nets made for that purpose only.

The Patassa, so called by the natives for its flatness, is the roach or fresh-water mullet of this country.

The Armed-Fish has its name from its arms, and its scaly mail. Its arms are its very sharp teeth, about the tenth of an inch in diameter, and as much distant from each other, and near half an inch long. The interval of the larger teeth is filled with shorter teeth. These arms are a proof of its voracity. Its mail is nothing but its scales, which are white, as hard as ivory, and about the tenth of an inch in thickness. They are near an inch long, about half as much in breadth, end in a 
point, and have two cutting sides. There are two ranges of them down the back, shaped exactly like the head of a spontoon, and opposite to the point of the scale has a little shank, about three tenths of an inch long, which the natives insert into the end of their arrows, making the scale serve for a head. The flesh of this fish is hard and not relishing.

There are a great number of Eels in the river Missisippi, and very large ones are found in all the rivers and creeks.

The whole lower part of the river abounds in Crayfish. Upon my first arrival in the colony the ground was covered with little hillocks, about six or seven inches high, which the crayfish had made for taking the air out of the water; but since dikes have been raised for keeping off the river from the low grounds, they no longer shew themselves. Whenever they are wanted, they fish for them with the leg of a frog, and in a few moments they will catch a large dish of them.

The Shrimps are diminutive crayfish; they are usually about three inches long, and of the size of the little finger. Although in other countries they are generally found in the sea only, yet in Louisiana you will meet with great numbers of them more than an hundred leagues up the river. In the lake St. Louis, about two leagues from New Orleans, the waters of which, having a communication with the sea, are somewhat brackish, are found several sorts both of sea fish, and fresh water fish. As the bottom of the lake is very level, they fish in it with large nets lately brought from France.

Near the lake, when we pass by the outlets to the sea, and continue along the coasts, we meet with small oysters in great abundance, that are very well tasted. On the other hand, when we quit the lake by another lake that communicates with one of the mouths of the river, we meet with oysters four or five inches broad, and six or seven long. These large oysters eat best fried, having hardly any saltness, but in other respects are large and delicate.

Having spoken of the oysters of Louisiana, I shall take some notice of the oysters that are found on the trees at St. Domingo. When I arrived at the harbour of Cape François in 
my way to Louisiana, I was much surprised to see oysters hanging to the branches of some shrubs; but M. Chaineau, who was our second captain, explained the phænomenon to me. According to him, the twigs of the shrubs are bent down at high water, to the very bottom of the shore, whenever the sea is any ways agitated. The oysters in that place no sooner feel the twigs than they lay hold of them, and when the sea retires they appear suspended upon them.

Towards the mouths of the river we meet with mussels no salter than the large oysters above mentioned; and this is owing to the water being only brackish in those parts, as the river there empties itself by three large mouths, and five other small ones, besides several short creeks, which all together throw at once an immense quantity of water into the sea; the whole marshy ground occupies an extent of ten or twelve leagues.

There are likewise excellent mussels upon the northern shore of the lake St. Louis, especially in the river of Pearls; they may be about six or seven inches long, and sometimes contain pretty large pearls, but of no great value.

The largest of the shell-fish on the coast is the Burgo, well known in France. There is another fish much smaller and of a different shape. Its hollow shell is strong and beautiful, and the flat one is generally black; some blue ones are found, and are much esteemed. These shells have long been in request for tobacco-boxes. 


\section{THE \\ HIS T O R Y \\ OF \\ LOUISIA N A}

BOOK IV.

Chapter I.

The Origin of the Americans.

THE remarkable difference I observed between the Natchez, including in that name the nations whom they treat as brethren, and the other people of Louisiana, made me extremely desirous to know whence both of them might originally come. We had not then that full information which we have since received from the voyages and discoveries of $M$. De Lisle in the eastern parts of the Russian empire. I therefore applied myself one day to put the keeper of the temple in good humour, and having succeeded in that without much difficulty, I then told him, that from the little resemblance I observed between the Natchez and the neighbouring nations, I was inclined to believe that they were not originally of the country which they then inhabited; and that if the ancient speech taught him any thing on that subject, he would do me a great pleasure to inform me of it. At these words he leaned his head on his two hands, with which he covered his eyes, and having remained in that posture about a quarter of an hour, as if to recollect himself, he answered to the following effect:

"Before we came into this land we lived yonder under the sun, (pointing with his finger nearly south-west, by which I understood that he meant Mexico;) we lived in a fine country where the earth is always pleasant; there our Suns had their abode, and our nation maintained itself for a long time against the ancients of the country, who conquered some of our vil- 
lages in the plains, but never could force us from the mountains. Our nation extended itself along the great water where this large river loses itself; but as our enemies were become very numerous, and very wicked, our Suns sent some of their subjects who lived near this river, to examine whether we could retire into the country through which it flowed. The country on the east side of the river being found extremely pleasant, the Great Sun, upon the return of those who had examined it, ordered all his subjects who lived in the plains, and who still defended themselves against the antients of this country, to remove into this land, here to build a temple, and to preserve the eternal fire.

"A great part of our nation accordingly settled here, where they lived in peace and abundance for several generations. The Great Sun, and those who had remained with him, never thought of joining us, being tempted to continue where they were by the pleasantness of the country, which was very warm, and by the weakness of their enemies, who had fallen into civil dissentions, in consequence of the ambition of one of their chiefs, who wanted to raise himself from a state of equality with the other chiefs of the villages, and to treat all the people of his nation as slaves. During those discords among our enemies, some of them even entered into an alliance with the Great Sun, who still remained in our old country, that he might conveniently assist our other brethren who had settled on the banks of the Great Water to the east of the large river, and extended themselves so far on the coast and among the isles, that the Great Sun did not hear of them sometimes for five or six years together.

"It was not till after many generations that the Great Suns came and joined us in this country, where, from the fine climate, and the peace we had enjoyed, we had multiplied like the leaves of the trees. Warriors of fire, who made the earth to tremble, had arrived in our old country, and having entered into an alliance with our brethren, conquered our ancient enemies; but attempting afterwards to make slaves of our Suns, they, rather than submit to them, left our brethren who refused to follow them, and came hither attended only with their slaves." 
Upon my asking him who those warriors of fire were, he replied, that they were bearded white men, somewhat of a brownish colour, who carried arms that darted out fire with a great noise, and killed at a great distance; that they had likewise heavy arms which killed a great many men at once, and like thunder made the earth tremble; and that they came from the sun-rising in floating villages.

The ancients of the country he said were very numerous, and inhabited from the western coast of the great water to the northern countries on his side the sun, and very far upon the same coast beyond the sun. They had a great number of large and small villages, which were all built of stone, and in which there were houses large enough to lodge a whole village. Their temples were built with great labour and art, and they made beautiful works of all kinds of materials.

But ye yourselves, said I, whence are ye come? The ancient speech, he replied, does not say from what land we came; all that we know is, that our fathers, to come hither, followed the sun, and came with him from the place where he rises; that they were a long time on their journey, were all on the point of perishing, and were brought into this country without seeking it.

To this account of the keeper of the temple, which was afterwards confirmed to me by the Great Sun, I shall add the following passage of Diodorus Siculus, which seems to confirm the opinion of those who think the eastern Americans are descended from the Europeans, who may have been driven by the winds upon the coasts of Guiana or Brazil.

"To the west of Africa, he says, lies a very large island, distant many days sail from that part of our continent. Its fertile soil is partly plain, and partly mountainous. The plain country is most sweet and pleasant, being watered every where with rivulets, and navigable rivers; it is beautified with many gardens, which are planted with all kinds of trees, and the orchards particularly are watered with pleasant streams. The villages are adorned with houses built in a magnificent taste, having parterres ornamented with arbours covered with flowers. Hither the inhabitants retire during the summer to enjoy the fruits which the country furnishes them with in the greatest 
abundance. The mountainous part is covered with large woods, and all manner of fruit trees, and in the vallies, which are watered with rivulets, the inhabitants meet with every thing that can render life agreeable. In a word, the whole island, by its fertility and the abundance of its springs, furnishes the inhabitants not only with every thing that may flatter their wishes, but with what may also contribute to their health and strength of body. Hunting furnishes them with such an infinite number of animals, that in their feasts they have nothing to wish for in regard either to plenty or delicacy. Besides, the sea, which surrounds the island, supplies them plentifully with all kinds of fish, and indeed the sea in general is very abundant. The air of this island is so temperate that the trees bear leaves and fruit almost the whole year round. In a word, this island is so delicious, that it seems rather the abode of the gods than of men.

"Anciently, on account of its remote situation, it was altogether unknown; but afterwards it was discovered by accident. It is well known, that from the earliest ages the Phenicians undertook long voyages in order to extend their commerce, and in consequence of those voyages established several colonies in Africa and the western parts of Europe. Every thing succeeding to their wish, and being become very powerful, they attempted to pass the pillars of Hercules and enter the ocean. They accordingly passed those pillars, and in their neighbourhood built a city upon a peninsula of Spain, which they named Gades. There, amongst the other buildings proper for the place, they built a temple to Hercules, to whom they instituted splendid sacrifices after the manner of their country. This temple is in great veneration at this day, and several Romans who have rendered themselves illustrious by their exploit.s, have performed their vows to Hercules for the success of their enterprizes.

"The Phenicians accordingly having passed the Streights of Spain, sailed along Africa, when by the violence of the winds they were driven far out to sea, and the storm continuing several days, they were at length thrown on this island. Being the first who were acquainted with its beauty and fertility, they 
published them to other nations. The Tuscans, when they were masters at sea, designed to send a colony thither, but the Carthaginians found means to prevent them on the two following accounts; first, they were afraid lest their citizens, tempted by the charms of that island, should pass over hither in too great numbers, and desert their own country; next they looked upon it as a secure asylum for themselves, if ever any terrible disaster should befal their republic."

This description of Diodorus is very applicable in many circumstances to America, particularly in the agreeable temperature of the climate to Africans, the prodigious fertility of the earth, the vast forests, the large rivers, and the multitude of rivulets and springs. The Natchez may then justly be supposed to be descended from some Phenicians or Carthaginians, who had been wrecked on the shores of South America, in which case they might well be imagined to have but little acquaintance with the arts, as those who first landed would be obliged to apply all their thoughts to their immediate subsistence, and consequently would soon become rude and barbarous. Their worship of the eternal fire likewise implies their descent from the Phenicians; for every body knows that this superstition, which first took its rise in Egypt, was introduced by the Phenicians into all the countries that they visited. The figurative stile, and the bold and Syriac expressions in the language of the Natchez, is likewise another proof of their being descended from the Phenicians*

As to those whom the Natchez, long after their first estab)lishment, found inhabiting the western coasts of America, and whom we name Mexicans, the arts which they possessed and cultivated with success, obliged me to give them a different origin. Their temples, their sacrifices, their buildings, their form of government, and their manner of making war, all denote a people who have transmigrated in a body, and brought with them the arts, the sciences, and the customs of their country. Those people had the art of writing, and also of

* The author might have mentioned a singular custom, in which both nations agree; for it appears from Polybius, 1 I. c. 6. that Carthaginians practised scalping. 
painting. Their archives consisted of cloths of cotton, whereon they had painted or drawn all those transactions which they thought worthy of being transmitted to posterity. It were greatly to be wished that the first conquerors of this new world had preserved to us the figures of those drawings; for by comparing them with the characters used by other nations, we might perhaps have discovered the origin of the inhabitants. The knowledge which we have of the Chinese characters, which are rather irregular drawings than characters, would probably have facilitated such a discovery; and perhaps those of Japan would have been found greatly to have resembled the Mexican; for I am strongly of opinion that the Mexicans are descended from one of those two nations.

In fact, where is the impossibility, that some prince in one of those countries, upon failing in an attempt to raise himself to the sovereign power, should leave his native country with all his partizans, and look for some new land, where, after he had established himself, he might drop all foreign correspondence? The easy navigation of the South Sea renders the thing probable; and the new map of the eastern bounds of Asia, and the western of North America, lately published by Mr. De Lisle, makes it still more likely. This map makes it plainly appear, that between the islands of Japan, or northern coasts of China, and those of America, there are other lands, which to this day have remained unknown; and who will take upon him to say there is no land, because it has never yet been discovered? I have therefore good grounds to believe, that the Mexicans came originally from China or Japan, especially when I consider their reserved and uncommunicative disposition, which to this day prevails among the people of the eastern parts of Asia. The great antiquity of the Chinese nation likewise makes it possible that a colony might have gone from thence to America early enough to be looked upon as the Ancients of the country, by the first of the Phenicians who could be supposed to arrive there. As a further corroboration of my conjectures, I was informed by a man of learning in 1752, that in the king's library there is a Chinese manuscript, which positively affirms that America was peopled by the inhabitants of Corea. 
When the Natchez retired to this part of America, where I saw them, they there found several nations, or rather the remains of several nations, some on the east, others on the west of the Missisippi. These are the people who are distinguished among the natives by the name of Red Men; and their origin is so much the more obscure, as they have not so distinct a tradition, as the Natchez, nor arts and sciences like the Mexicans, from whence we might draw some satisfactory inferences. All that I could learn from them was, that they came from between the north and the sun-setting; and this account they uniformly adhered to whenever they gave any account of their origin. This lame tradition no ways satisfying the desire I had to be informed on this point, I made great inquiries to know. if there was any wise old man among the neighbouring nations, who could give me further intelligence about the origin of the natives. I was happy enough to discover one, named Moncacht-apé among the Yazous, a nation about forty leagues north from the Natchez. This man was remarkable for his solid understanding and elevation of sentiments; and I may justly compare him to those first Greeks, who travelled chiefly into the east to examine the manners and customs of different nations, and to communicate to their fellow-citizens, upon their return, the knowledge which they had acquired. Moncacht-apé, indeed, never executed so noble a plan; but he had however conceived it, and had spared no labour and pains to effectuate it. He was by the French called the Interpreter, because he understood several of the North American languages; but the other name which I have mentioned was given him by his own nation, and signifies the killer of pain and fatigue. This name was indeed most justly applicable to him; for, to satisfy his curiosity, he had made light of the most dangerous and painful journeys, in which he had spent several years of his life. He stayed two or three days with me; and upon my desiring him to give me an account of his travels, he very readily complied with my request, and spoke to the following effect:

"I had lost my wife, and all the children whom I had by her, when I undertook my journey towards the sun-rising. I set out from my village contrary to the inclinations of all $\mathrm{my}$ 
relations, and went first to the Chicasaws, our friends and neighbours. I continued among them several days to inform myself whether they knew whence we all came, or at least whence they themselves came; they, who were our elders; since from them came the language of the country. As they could not inform me, I proceeded on my journey. I reached the country of the Chaouanous, and afterwards went up the Wabash or Ohio, almost to its source, which is in the country of the Iroquois or Five Nations. I left them however towards the north; and during the winter, which in that country is very severe and very long, I lived in a village of the Abenaquis, where I contracted an acquaintance with a man somewhat older than myself, who promised to conduct me the following spring to the Great Water. Accordingly when the snows were melted, and the weather was settled, we proceeded eastward, and, after several days journey, I at length saw the Great Water, which filled me with such joy and admiration that I could not speak. Night drawing on, we took up our lodging on a high bank above the water, which was sorely vexed by the wind, and made so great a noise that I could not sleep. Next day the ebbing and flowing of the water filled me with great apprehension; but my companion quieted my fears, by assuring me that the water observed certain bounds both in advancing and retiring. Having satisfied our curiosity in viewing the Great Water, we returned to the village of the Abenaquis, where I continued the following winter; and after the snows were melted, my companion and I went and viewed the great fall of the river St. Laurence at Niagara, which was distant from the village several days journey. The view of this great fall at first made my hair stand on end, and my heart almost leap out of its place; but afterwards, before I left it, I had the courage to walk under it. Next day we took the shortest road to the Ohio, and my companion and I cutting down a tree on the banks of the river, we formed it into a pettiaugre, which served to conduct me down the Ohio and the Missisippi, after which, with much difficulty, I went up our small river; and at length arrived safe among my relations, who were rejoiced to see me in good health. 
"This journey, instead of satisfying, only served to excite my curiosity. Our old men, for several years, had told me that the antient speech informed them that the Red Men of the north came originally much higher and much farther than the source of the river Missouri; and as I had longed to see, with my own eyes, the land from whence our first fathers came, I took my precautions for my journey westwards. Having provided a small quantity of corn, I proceeded up along the eastern bank of the river Missisippi, till I came to the Ohio. I went up along the bank of this last river about the fourth part of a day's journey, that I might be able to cross it without being carried into the Missisippi. There I formed a Cajeux or raft of canes, by the assistance of which I passed over the river; and next day meeting with a herd of buffaloes in the meadows, I killed a fat one, and took from it the fillets, the bunch, and the tongue. Soon after I arrived among the Tamaroas, a village of the nation of the Illinois, where I rested several days, and then proceeded northwards to the mouth of the Missouri, which, after it enters the great river, runs for a considerable time without intermixing its muddy waters with the clear stream of the other. Having crossed the Missisippi, I went up the Missouri along its northern bank, and after several days journey I arrived at the nation of the Missouris, where I staid a long time to learn the language that is spoken beyond then. In going along the Missouri I passed through meadows a whole day's journey in length, which were quite covered with buffaloes.

"When the cold was past, and the snows were melten, I continued my journey up along the Missouri till I came to the nation of the West, or the Canzas., Afterwards, in consequence of directions from them, I proceeded in the same course near thirty days, and at length I met with some of the nation of the Otters, who were hunting in that neighbourhood, and were surprised to see me alone. I continued with the hunters two or three days, and then accompanied one of them and his wife, who was near her time of lying-in, to their village, which lay far off betwixt the north and west. We continued our journey along the Missouri for nine days, and then we marched 
directly northwards for five days more, when we came to the Fine River, which runs westwards in a direction contrary to that of the Missouri. We proceeded down this river a whole day, and then arrived at the village of the Otters, who received me with as much kindness as if I had been of their own nation. A few days after I joined a party of the Otters, who were going to carry a calumet of peace to a nation beyond them, and we embarked in a pettiaugre, and went down the river for eighteen days, landing now and then to supply ourselves with provisions. When I arrived at the nation who were at peace with the Otters, I staid with them till the cold was passed, that I might learn their language, which was common to most of the nations that lived beyond them.

"The cold was hardly gone, when I again embarked on the Fine River, and in my course I met with several nations, with whom I generally staid but one night, till I arrived at the nation that is but one day's journey from the Great Water on the west. This nation live in the woods about the distance of a league from the river, from their apprehension of bearded men, who come upon their coasts in floating villages, and carry off their children to make slaves of them. These men were described to be white, with long black beards that came down to their breasts; they were thick and short, had large heads, which were covered with cloth; they were alway; dressed, even in the greatest heats; their cloaths fell down to the middle of their legs, which with their feet were covered with red or yellow stuff. Their arms made a great fire and a great noise; and when they saw themselves outnumbered by Red Men, they retired on board their large pettiaugre, their number sometimes amounting to thirty, but never more.

"Those strangers came from the sun-setting, in search of a yellow stinking wood, which dyes a fine yellow colour; but the people of this nation, that they might not be tempted to visit them, had destroyed all those kind of trees. Two other nations in their neighbourhood however, having no other wood, could not destroy the trees, and were still visited by the strangers; and being greatly incommoded by them, had invited their allies to assist them in making an attack upon them the next 
time they should return. The following summer I accordingly joined in this expedition, and after traveling five long days journey, we came to the place where the bearded men usually landed, where we waited seventeen days for their arrival. The Red Men, by my advice, placed themselves in ambuscade to surprize the strangers, and accordingly when they landed to cut the wood, we were so successful as to kill eleven of them, the rest immediately escaping on board two large pettiaugres, and flying westward upon the Great Water.

"Upon examining those whom we had killed, we found them much smaller than ourselves, and very white; they had a large head, and in the middle of the crown the hair was very long; their head was wrapt in a great many folds of stuff, and their cloaths seemed to be made neither of wool nor silk; they were very soft, and of different colours. Two only of the eleven who were slain had fire-arms with powder and ball. I tried their pieces, and found that they were much heavier than yours, and did not kill at so great a distance.

"After this expedition I thought of nothing but proceeding on my journey, and with that design I let the Red Men return home, and joined myself to those who inhabited more westward on the coast, with whom I travelled along the shore of the Great Water, which bends directly betwixt the north and the sun-setting. When I arrived at the villages of my fellowtravellers, where I found the days very long and the night very short, I was advised by the old men to give over all thoughts of continuing my journey. They told me that the land extended still a long way in a direction between the north and sunsetting, after which it ran directly west, and at length was cut by the Great Water from north to south. One of them added, that when he was young, he knew a very old man who had seen that distant land before it was eat away by the Great Water, and that when the Great Water was low, many rocks still appeared in those parts. Finding it therefore impracticable to proceed much further, on account of the severity of the climate, and the want of game, I returned by the same route by which I had set out; and reducing my whole travels westward to days journeys, I compute that they would have em- 
ployed me thirty-six moons; but on account of my frequent delays, it was five years before I returned to my relations among the Yazous."

Moncacht-apé, after giving me an account of his travels, spent four or five days visiting among the Natchez, and then returned to take leave of me, when I made him a present of several wares of no great value, among which was a concave mirror about two inches and a half diameter, which had cost me about three halfpence. As this magnified the face to four or five times its natural size, he was wonderfully delighted with it, and would not have exchanged it with the best mirror in France. After expressing his regret at parting with me, he returned highly satisfied to his own nation.

Moncacht-apé's account of the junction of America with the eastern parts of Asia seems confirmed from the following remarkable fact. Some years ago the skeletons of two large elephants and two small ones were discovered in a marsh near the river Ohio; and as they were not much consumed, it is supposed that the elephants came from Asia not many years before. If we also consider the form of government, and the manner of living among the northern nations of America, there will appear a great resemblance betwixt them and the Tartars in the north-east parts of Asia.

\section{Chapter II.}

An Account of the Several Nations of Indians in Louisiana.

\section{SECTION I.}

Of the Nations inhabiting on the East of the Missisippi. IF to the history of the discoveries and conquests of the 1 Spaniards we join the tradition of all the nations of America, we shall be fully persuaded, that this quarter of the world, before it was discovered by Christopher Columbus, was very populous, not only on the continent but also in the islands.

However, by an incomprehensible fatality, the arrival of the Spaniards in this new world seems to have been the unhappy epoch of the destruction of all the nations of America, 
not only by war, but by nature itself. As it is but too well known how many millions of natives were destroyed by the Spanish sword, I shall not therefore present my readers with that horrible detail; but perhaps many people do not know that an innumerable multitude of the natives of Mexico and Peru voluntarily put an end to their own lives, some by sacrificing themselves to the manes of their sovereigns who had been cut off, and whose born victims they, according to their detestable customs, looked upon themselves to be; and others, to avoid falling under the subjection of the Spaniards, thinking death a less evil by far than slavery.

The same effect has been produced among the people of North America by two or three warlike nations of the natives. The Chicasaws have not only cut off a great many nations who were adjoining to them, but have even carried their fury as far as New Mexico, near six hundred miles from the place of their residence, to root out a nation that had removed at that distance from them, in a firm expectation that their enemies would not come so far in search of them. They were however deceived and cut off. The Iroquois have done the same in the east parts of Louisiana; and the Padoucas and others have acted in the same manner to nations in the west of the colony. We may here observe, that those nations could not succeed against their enemies without considerable loss to themselves, and that they have therefore greatly lessened their own numbers by their many warlike expeditions.

I mentioned that nature had contributed no less than war to the destruction of these people. Two distempers, that are not very fatal in other parts of the world, make dreadful ravages among them; I mean the small-pox and a cold, which baffle all the art of their physicians, who in other respects are very skilful. When a nation is attacked by the small-pox, it quickly makes great havock; for as a whole family is crowded into a small hut, which has no communications with the external air, but by a door about two feet wide and four feet high, the distemper, if it seizes one, is quickly communicated to all. The aged die in consequence of their advanced years and the bad quality of their food; and the young, if they are not 
strictly watched, destroy themselves, from an abhorrence of the blotches in their skin. If they can but escape from their hut, they run out and bathe themselves in the river, which is certain death in that distemper. The Chatkas, being naturally not very handsome, are not so apt to regret the loss of their beauty; consequently. suffer less, and are much more numerous than the other nations.

Colds; which are very common in the winter, likewise destroy great numbers of the natives. In that season they keep fires in their huts day and night; and as there is no other opening but the door, the air within the hut is kept excessive warm without any free circulation; so that when they have occasion to go out, the cold seizes them, and the consequences of it are almost always fatal.

The first nations that the French were acquainted with in this part of North America, were those on the east of the colony; for the first settlement we made there was at Fort Louis on the river Mobile. I shall therefore begin my account of the different nations of Indians on this side of the colony, and proceed westwards in the same order as they are situated.

But however zealous I may be in displaying not only the beauties, but the riches and advantages of Louisiana, yet I am not at all inclined to attribute to it what it does not possess; therefore I warn my reader not to be surprised, if I make mention of a few nations in this colony, in comparison of the great number which he may perhaps have seen in the first maps of this country. Those maps were made from memoirs sent by different travellers, who noted down all the names they heard mentioned, and then fixed upon a spot for their residence; so that a map appeared stiled with the names of nations, many of whom were destroyed, and others were refugees among nations who had adopted them and taken them under their protection. Thus, though the nations on this continent were formerly both numerous and populous, they are now so thinned and diminished, that there does not exist at present a third part of the nations whose names are to be found in the maps.

The most eastern nation of Louisiana is that called the Apalaches, which is a branch of the great nation of the Apa- 
laches, who inhabited near the mountains to which they have given their name. This great nation is divided into several branches, who take different names. The branch in the neighbourhood of the river Mobile is but inconsiderable, and part of it is Roman Catholic.

On the north of the Apalaches are the Alibamous, a pretty considerable nation; they love the French, and receive the English rather out of necessity than friendship. On the first settling of the colony we had some commerce with them; but since the main part of the colony has fixed on the river, we have somewhat neglected them, on account of the great distance.

East from the Alibamous are the Caouitas, whom M. de Biainville, governor of Louisiana, wanted to distinguish above the other nations, by giving the title of emperor to their sovereign, who then would have been chief of all the neighbouring nations; but those nations refused to acknowledge him as such, and said that it was enough if each nation obeyed its own chief; that it was improper for the chiefs themselves to be subject to other chiefs, and that such a custom had never prevailed among them, as they chose rather to be destroyed by a great nation than to be subject to them. This nation is one of the most considerable; the English trade with them, and they suffer the traders to come among them from policy.

To the north of the Alibamous are the Abeikas and Conchacs, who, as far as I can learn, are the same people; yet the name of Conchac seems appropriated to one part more than another. They are situated at a distance from the great rivers and consequently have no large canes in their territory. The canes that grow among them are not thicker than one's finger, and are at the same time so very hard, that when they are split, they cut like knives, which these people call conchacs. The language of this nation is almost the same with that of the Chicasaws, in which the word conchac signifies a knife.

The Abeikas, on the east of them, have the Cherokees, divided into several branches, and situated very near the Apalachean mountains. All the nations whom I have mentioned 
have been united in a general alliance for a long time past, in order to defend themselves against the Iroquois, or Five Nations, who, before this alliance was formed, made continual war upon them; but have ceased to molest them since they have seen them united. All these nations, and some small ones intermixed among them, have always been looked upon as belonging to no colony, excepting the Apalaches; but since the breaking out of the war with the English in 1756, it is said they have voluntarily declared for us.

The nations in the neighbourhood of the Mobile, are first the Chatots, a small nation consisting of about forty huts, adjoining to the river and the sea. They are Roman Catholics, or reputed such; and are friends to the French, whom they are always ready to serve upon being paid for it. North from the Chatots, and very near them, is the French settlement of Fort Louis on the Mobile.

A little north from Fort Louis are situated the Thomez, which are not more numerous than the Chatots, and are said to be Roman Catholics. They are our friends to to such a degree as even to teaze us with their officiousness.

Further north live the Taensas, who are a branch of the Natchez, of whom I shall have occasion to speak more at large. Both of these nations keep the eternal fire with the utmost care; but they trust the guard of it to men, from a persuasion that none of their daughters would sacrifice their liberty for that office. The whole nation of the Taensas consists only of about one hundred huts.

Proceeding still northwards along the bay, we meet with the nation of the Mobiliens, near the mouth of the river Mobile, in the bay of that name. The true name of this nation is Mouvill, which the French have turned into Mobile, calling the river and the bay from the nation that inhabited near them. All these small nations were living in peace upon the arrival of the French, and still continue so; the nations on the east of the Mobile serving as a barrier to them against the incursions of the Iroquois. Besides, the Chicasaws look upon them as their brethren, as both they, and their neighbours on the east of the 
Mobile, speak a language which is nearly the same with that of the Chicasaws.

Returning towards the sea, on the west of the Mobile, we find the small nation of the Pacha-Ogoulas, that is, Nation of Bread, situated upon the bay of the same name. This nation consists only of one village of about thirty huts. Some French Canadians have settled in their neighbourhood, and they live together like brethren, as the Canadians, who are naturally of a peaceable disposition, know the character of the natives, and have the art of living with the nations of America. But what chiefly renders the harmony betwixt them durable, is the absence of soldiers, who never appear in this nation.

Further northwards, near the river Pacha-Ogoulas, is situated the great nation of the Chatkas, or Flat-heads. I call them the great nation, for I have not known or heard of any other near so numerous. They reckon in this nation twentyfive thousand warriors. There may perhaps be such a number of men among them, who take that name; but I am far from thinking that all these have a title to the character of warriors.

According to the tradition of the natives, this nation arrived so suddenly, and passed so rapidly through the territories of others, that when I asked them, whence came the Chatkas? they answered me, that they sprung out of the ground; by which they meant to express their great surprize at seeing them appear so suddenly. Their great numbers awed the natives near whom they passed; their character being but little inclined to war, did not inspire them with the fury of conquest; thus they at length arrived in an uninhabited country which nobody disputed with them. They have since lived without any disputes with their neighbours; who on the other hand have never dared to try whether they were brave or not. It is doubtless owing to this that they have increased to their present numbers.

They are called Flat-heads; but I do not know why that name has been given to them more than to others, since all the nations of Louisiana have their heads as flat, or nearly so. They are situated about two hundred and fifty miles north 


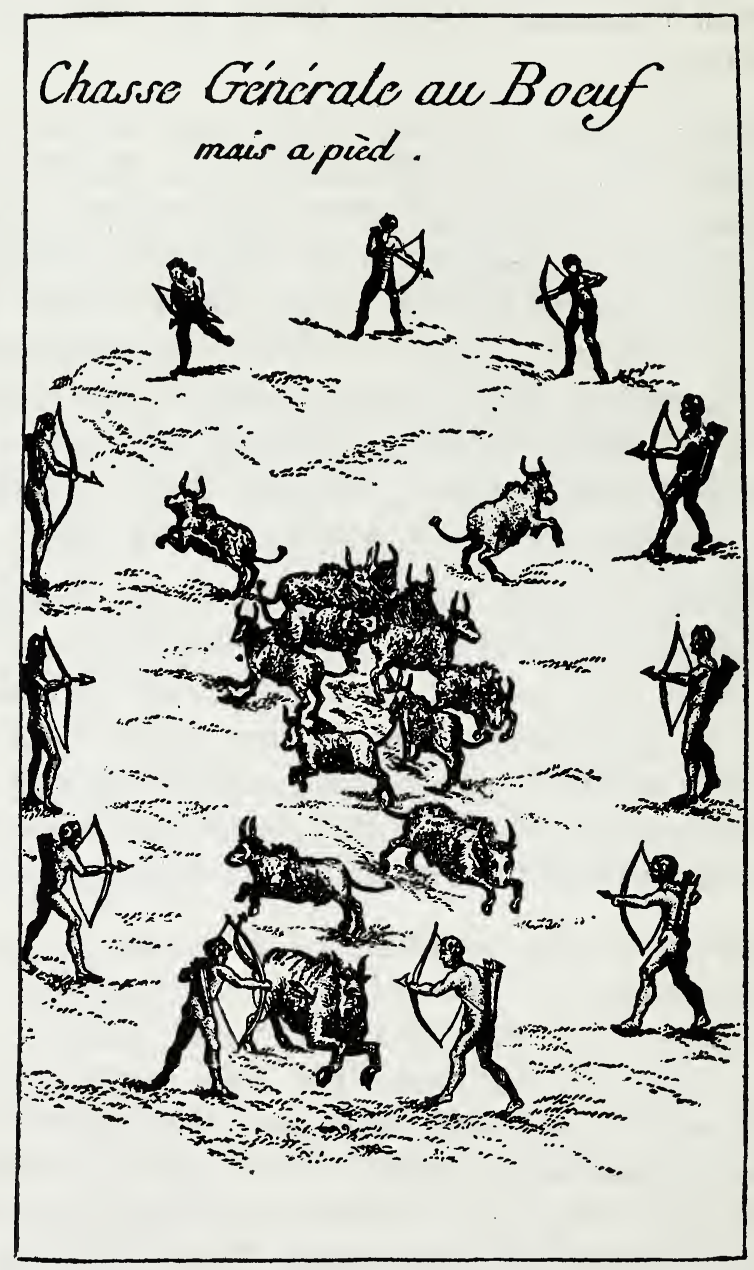

Indian Buffalo Hunt on foot

from the sea, and extend more from east to west than from south to north.

Those who travel from the Chatkas to the Chicasaws, seldom go by the shortest road, which extends about one hundred and eighty miles, and is very woody and mountainous. They choose rather to go along the river Mobile, which is both the easiest and most pleasant route. The nation of the Chicasaws is very warlike. The men have very regular features, 
are large, well-shaped, and neatly dressed; they are fierce, and have a high opinion of themselves. They seem to be the remains of a populous nation, whose warlike disposition had prompted them to invade several nations, whom they have indeed destroyed, but not without diminishing their own numbers by those expeditions. What induces me to believe that this nation has been formerly very considerable, is that the nations who border upon them, and whom I have just mentioned, speak the Chicasaw language, though somewhat corrupted, and those who speak it best value themselves upon it.

I ought perhaps to except out of this number the Taensas, who being a branch of the Natchez, have still preserved their peculiar language; but even these speak, in general, the corrupted Chicasaw language, which our French settlers call the Mobilian language. As to the Chatkas, I suppose, that being very numerous, they have been able to preserve their own language in a great measure; and have only adopted some words of the Chicasaw language. They always spoke to me in the Chicasaw tongue.

In returning towards the coast next the river Missisippi, we meet with a small nation of about tweny huts, named Aquelou-Pissas, that is, Men who understand and see. This nation formerly lived within three of four miles of the place where New Orleans is built; but they are further north at present, and not far from the lake St. Lewis, or Pontchartrain. They speak a language somewhat approaching to that of the Chicasaws. We have never had great dealings with them.

Being now arrived at the river Missisippi, I shall proceed upwards along its banks as far as to the most distant nations that are known to us.

The first nation that I meet with is the Oumas, which signifies the Red Nation. They are situated about twenty leagues from New Orleans, where I saw some of them upon my arrival in this province. Upon the first establishment of the colony, some French went and settled near them; and they have been very fatal neighbours, by furnishing them with brandy, which they drink to great excess. 
Crossing the Red River, and proceeding still upwards, we find the remains of the nation of the Tonicas, who have always been very much attached to the French, and have even been our auxiliaries in war. The Chief of this nation was our very zealous friend; and as he was full of courage, and always ready to make war on the enemies of the French, the king sent him a brevet of brigadier of the red armies, and a blue ribbon, from whence hung a silver medal, which on one side represented the marriage of the king, and on the reverse had the city of Paris. He likewise sent him a gold-headed cane; and the Indian Chief was not a little proud of wearing, those honourable distinctions, which were certainly well bestowed. This nation speaks a language so far different from that of their neighbours, in that they pronounce the letter $R$, which the others have not. They have likewise different customs.

The Natchez in former times appear to have been one of the most respectable nations in the colony, not only from their own tradition, but from that of the other nations, in whom their greatness and civilized customs raised no less jealousy than admiration. I could fill a volume with what relates to this people alone; but as I am now giving a concise account of the people of Louisiana, I shall speak of them as of the rest, only enlarging a little upon some important transactions concerning them.

When I arrived in 1720 among the Natchez, that nation was situated upon a small river of the same name; the chief village where the Great Sun resided was built along the banks of the river, and the other villages were planted round it. They were two leagues above the confluence of the river, which joins the Missisippi at the foot of the great precipices of the Natchez. From thence are four leagues to its source, and as many to Rosalie, and they were situated within a league of the fort.

Two small nations lived as refugees among the Natchez. The most ancient of these adopted nations were the Grigras, who seem to have received that name from the French, because when talking with one another they often pronounce those two syllables, which makes them be remarked as strangers among the Natchez, who, as well as the Chicasaws, and all the nations 
that speak the Chicasaw language, cannot pronounce the letter $\mathbf{R}$.

The other small nation adopted by the Natchez, are the Thioux, who have also the letter $R$ in their language. These were the weak remains of the Thioux nation, formerly one of the strongest in the country. However, according to the account of the other nations, being of a turbulent disposition, they drew upon themselves the resentment of the Chicasaws, which was the occasion of their ruin; for by their many engagements they were at length so weakened that they durst not face their enemy, and consequently were obliged to take refuge among the Natchez.

The Natchez, the Grigras, and the Thioux, may together raise about twelve hundred warriors; which is but a small force in comparison of what the Natchez could formerly have raised alone; for according to their traditions they were the most powerful nation of all North America, and were looked upon by the other nations as their superiors, and on that account respected by them. To give an idea of their power, I shall only mention, that formerly they extended from the river Manchac, or Iberville, which is about fifty leagues from the sea, to the river Wabash, which is distant from the sea about four hundred and sixty leagues; and that they had about five hundred Suns or princes. From these facts we may judge how populous this nation formerly has been; but the pride of their Great Suns, or sovereigns, and likewise of their inferior Suns, joined to the prejudices of the people, has made greater havock among them, and contributed more to their destruction, than long and bloody wars would have done.

As their sovereigns were despotic, they had for a long time past established the following inhuman and impolitic custom, that when any of them died, a great number of their subjects, both men and women, should likewise be put to death. A proportionable number of subjects were likewise killed upon the death of any "of the inferior Suns; and the people on the other hand had imbibed a belief that all those who followed their princes into the other world, to serve them there, would be eternally happy. It is easy to conceive how ruinous such an 
inhuman custom would be among a nation who had so many princes as the Natchez.

It would seem that some of the Suns, more humane than the rest, had disapproved of this barbarous custom, and had therefore retired to places at a remote distance from the centre of their nation. For we have two branches of this great nation settled in other parts of the colony, who have preserved the greatest part of the customs of the Natchez. One of these branches is the nation of the Taensas on the banks of the Mobile, who preserve the eternal fire, and several other usages of the nation from whom they are descended. The other branch is the nation of the Chitimachas, whom the Natchez have always looked upon as their brethren.

Forty leagues north from the Natchez is the river Yasous, which runs into the Missisippi, and is so called from a nation of the same name who had about a hundred huts on its banks.

Near the Yazous, on the same river, lived the Coroas, a nation consisting of about forty huts. These two nations pronounce the letter $\mathbf{R}$.

Upon the same river likewise lived the Chacchi-Oumas, a name which signifies red Cray-fish. These people had not above fifty huts.

Near the same river dwelt the Ouse-Ogoulas, or the Nation of the Dog, which might have about sixty huts.

The Tapoussas likewise inhabited upon the banks of this river, and had not above twenty-five huts. These three last nations do not pronounce the letter $R$, and seem to be branches of the Chicasaws, especially as they speak their language. Since the massacre of the French settlers at the Natchez, these five small nations, who had joined in the conspiracy against us, have all retired among the Chicasaws, and make now but one nation with them.

To the north of the Ohio, not far from the banks of the Missisippi, inhabit the Illinois, who have given their name to the river on the banks of which they have settled. They are divided into several villages, such as the Tamaroas, the Cas- 
kaquias, the Caouquias, the Pimiteouis, and some others. Near the village of the Tamaroas is a French post, where several French Canadians have settled.

This is one of the most considerable posts in all Louisiana, which will appear not at all surprising, when we consider that the Illinois were one of the first nations whom we discovered in the colony, and that they have always remained most faithful allies of the French; an advantage which is in a great measure owing to the proper manner of living with the natives of America, which the Canadians have always observed. It is not their want of courage that renders them so peaceable, for their valour is well known. The letter $R$ is pronounced by the Illinois.

Proceeding further northwards we meet with a pretty large nation, known by the name of the Foxes, with whom we have been at war near these forty years past, yet I have not heard that we have had any blows with them for a long time.

From the Foxes to the fall of St. Anthony, we meet with no nation, nor any above the Fall for near an hundred leagues. About that distance north of the Fall, the Sioux are settled, and are said to inhabit several scattered villages both on the east and west of the Missisippi.

\section{SECTION II.}

Of the Nations inhabiting on the West of the Missisippi.

HAVING described as exactly as possible all the nations on the east of the Missisippi, as well those who are included within the bounds of the colony, as those who are adjoining to it, and have some connection with the others; I shall now proceed to give an account of those who inhabit on the west of the river, from the sea northwards.

Between the river Missisippi, and those lakes which are filled by its waters upon their overflowing, is a small nation named Chaouchas, or Ouachas, who inhabit some little villages, but are of so little consequences that they are no otherwise known to our colonists but by their name. 
In the neighbourhood of the lakes abovementioned live the Chitimachas. These are the remains of a nation which was formerly pretty considerable; but we have destroyed part of them by exciting our allies to attack them. I have already observed that they were a branch of the Natchez, and upon my first settling among these, I found several Chitimachas, who had taken refuge among them to avoid the calamities of the war which had been made upon them near the lakes.

Since the peace that was concluded with them in 1719 , they have not only remained quiet, but kept themselves so prudently retired, that, rather than have any intercourse with the French, or traffic with them for what they look upon as superfluities, they choose to live in the manner they did an hundred years ago.

Along the west coast, not far from the sea, inhabit the nation named Atacapas, that is, Man-eaters, being so called by the other nations on account of their detestable custom of eating their enemies, or such as they believe to be their enemies. In this vast country there are no other cannibals to be met with besides the Atacapas; and since the French have gone among them, they have raised in them so great an horror of that abominable practice of devouring creatures of their own species, that they have promised to leave it off; and accordingly for a long time past we have heard of no such barbarity among them.

The Bayouc-Ogoulas were formerly situated in the country that still bears their name. This nation is now confounded with the others to whom it is joined.

The Oque-Loussas are a small nation situated northwest from the Cut Point. They live on the banks of two small lakes, the waters of which appear black by reason of the great number of leaves which cover the bottom of them, and have given name to the nation, Oque-Loussas in their language signifying Black Water.

From the Oque-Loussas to the Red River, we meet with no other nation; but upon the banks of this river, a little above the Rapid, is seated the small nation of the Avoyels. These are the people who bring to our settlers horses, oxen, and cows. 
I know not in what fair they buy them, nor with what money they pay for them; but the truth is, they sell them to us for about seventeen shillings a-piece. The Spaniards of New-Spain have such numbers of them that they do not know what to do with them, and are obliged to those who will take them off their hands. At present the French have a greater number of them than they want, especially of horses.

About fifty leagues higher up the Red River, live the Nachitoches, near a French post of the same name. They are a pretty considerable nation, having about two hundred huts. They have always been greatly attached to the French; but never were friends to the Spaniards. There are some branches of this nation situated further westward; but the huts are not numerous.

Three hundred miles west from the Missisippi, upon the Red River, we find the great nation of the Cadodaquioux. It is divided into several branches which extend very widely. This people, as well as the Nachitoches, have a peculiar language; however, there is not a village in either of the nations, nor indeed in any nation of Louisiana, where there are not some who can speak the Chicasaw language, which is called the vulgar tongue, and is the same here as the Lingua Franca is in the Levant.

Between the Red River and the Arkansas there is at present no nation. Formerly the Ouachites lived upon the Black River, and gave their name to it; but at this time there are no remains of that nation; the Chicasaws having destroyed great part of them, and the rest took refuge among the Cadodaquioux, where their enemies durst not molest them. The Taensas lived formerly in this neighbourhood upon a river of their name; but they took refuge on the banks of the Mobile near the allies of the Chicasaws, who leave them undisturbed.

The nation of the Arkansas have given their name to the river on which they are situated, about four leagues from its confluence with the Missisippi. This nation is pretty considerable, and its men are no less distinguished for being good hunters than stout warriors. The Chicasaws, who are of a 
restless disposition, have more than once wanted to make trial of the bravery of the Arkansas; but they were opposed with such firmness, that they have now laid aside all thoughts of attacking them, especially since they have been joined by the Kappas, the Michigamias, and a part of the Illinois, who have settled among them. Accordingly there is no longer any mention either of the Kappas or Michigamias, who are now all adopted by the Arkansas.

The reader may have already observed in this account of the natives of Louisiana, that several nations of those people had joined themselves to others, either because they could no longer resist their enemies, or because they hoped to improve their condition by intermixing with another nation. I am glad to have this occasion of observing that those people respect the rights of hospitality, and that those rights always prevail, notwithstanding any superiority that one nation may have over another with whom they are at war, or even over those people among whom their enemies take refuge. For example, a nation of two thousand warriors makes war upon, and violently pursues another nation of five hundred warriors, who retire among a nation in alliance with their enemies. If this last nation adopt the five hundred, the first nation, though two thousand in number, immediately lay down their arms, and instead of continuing hostilities, reckon the adopted nation among the number of their allies.

Besides the Arkansas, some authors place other nations upon their river. I cannot take upon me to say that there never were any; but I can positively affirm, from my own observation upon the spot, that no other nation is to be met with at present on this river, or even as far as the Missouri.

Not far from the river Missouri is situated the nation of the Osages, upon a small river of the same name. This nation is said to have been pretty considerable formerly, but at present they can neither be said to be great nor small.

The nation of the Missouris is very considerable, and has given its name to the large river that empties itself into the Missisippi. It is the first nation we meet with from the con- 
fluence of the two rivers, and yet it is situated above forty leagues up the Missouri. The French had a settlement pretty near this nation, at the time when $M$. de Bourgmont was commandant in those parts; but soon after he left them, the inhabitants massacred the French garrison.

The Spaniards, as well as our other neighbours, being continually jealous of our superiority over them, formed a design of establishing themselves among the Missouris, about forty leagues from the Illinois, in order to limit our boundaries westward. They judged it necessary, for the security of their colony, entirely to cut off the Missouris, and for that purpose they courted the friendship of the Osages, whose assistance they thought would be of service to them in their enterprize, and who were generally at enmity with the Missouris. A company of Spaniards, men, women, and soldiers, accordingly set out from Santa Fe, having a Dominican for their chaplain, and an engineer for their guide and commander. The caravan was furnished with horses, and all other kinds of beasts necessary; for it is one of their prudent maxims, to send off all those things together. By a fatal mistake the Spaniards arrived first among the Missouris, whom they mistook for the Osages, and imprudently discovering their hostile intentions, they were themselves surprised and cut off by those whom they intended for destruction. The Missouris some time afterwards dressed themselves with the ornaments of the chapel; and carried them in a kind of triumphant procession to the French commandant among the Illinois. Along with the ornaments they brought a Spanish map, which seemed to me to be a better draught of the west part of our colony, towards them, than of the countries we are most concerned with. From this map it appears, that we ought to bend the Red River, and that of the Arkansas, somewhat more, and place the source of the Missisippi more westerly than our geographers do.

The principal nations who inhabit upon the banks, or in the neighbourhood of the Missouri, are, besides those already mentioned, the Canzas, the Othoues, the White Panis, the Black Panis, the Panimachas, the Aiouez, and the Padoucas. The most numerous of all those nations are the Padoucas, the small- 
est are the Aiouez, the Othoues, and the Osages; the others are pretty considerable.

To the north of all those nations, and near the river Missisippi, it is pretended that a part of the nation of the Sioux have their residence. Some affirm that they inhabit now on one side of the river, now on another. From what I could learn from travellers, I am inclined to think, that they occupy at the same time both sides of the Missisippi, and their settlements, as I have elsewhere observed, are more than an hundred leagues above the Fall of St. Anthony. But we need not yet disquiet ourselves about the advantages which might result to us from those very remote countries. Many ages must pass before we can penetrate into the northern parts of Louisiana.

\section{CHAPTER III.}

A Description of the natives of Louisiana; of their manners and customs, particularly those of the Natchez: of their language, their religion, ceremonies, Rulers or Suns, feasts, marriages, \&c.

\section{SECTION I.}

$A$ description of the natives; the different employments of the two sexes; and their manner of bringing up their children.

IN the concise history which I have given of the people of Louisiana, and in several other places where I have happened to mention them, the reader may have observed that these nations have not all the same character, altho' they live adjoining to each other. He therefore ought not to expect a perfect uniformity in their manners, or that I should describe all the different usages that prevail in different parts, which would create a disagreeable medley, and tend only to confound his ideas which cannot be too clear. My design is only to shew in general, from the character of those people, what course we ought to observe, in order to draw advantage from our intercourse with them. I shall however be more full in speaking of the Natchez, a populous nation, among whom I lived the space of eight years, and whose sovereign, the chief of war, and the chief of the keepers of the temple, were among my most inti- 
mate friends. Besides, their manners were more civilized, their manner of thinking more just and fuller of sentiment, their customs more reasonable, and their ceremonies more natural and serious; on all which accounts they were eminently distinguished above the other nations.

All the natives of America in general are extremely well made; very few of them are to be seen under five feet and a half, and very many of them above that; their leg seems as if it was fashioned in a mould; it is nervous, and the calf is firm; they are long waisted; their head is upright and somewhat flat in the upper part, and their features are regular; they have black eyes, and thick black hair without curls. If we see none that are extremely fat and pursy, neither do we meet with any that are so lean as if they were in a consumption. The men in general are better made than the women; they are more nervous, and the women more plump and fleshy; the men are almost all large, and the women of a middle size. I have always been inclined to think, that the care they take of their children in their infancy contributes greatly to their fine shapes, tho' the climate has also its share in that, for the French born in Louisiana are all large, well shaped, and of good flesh and blood.

When any of the women of the natives is delivered, she goes immediately to the water and washes herself and the infant; she then comes home and lies down, after having disposed her infant in the cradle, which is about two feet and a half long, nine inches broad, and half a foot deep, being formed of straight pieces of cane bent up at one end, to serve for a foot or stay. Betwixt the canes and the infant is a kind of matrass of the tufted herb called Spanish Beard, and under its head is a little skin cushion, stuffed with the same herb. The infant is laid on its back in the cradle, and fastened to it by the shoulders, the arms, the legs, the thighs, and the hips; and over its forehead are laid two bands of deer-skin which keeps its head to the cushion, and renders that part flat. As the cradle does not weigh much above two pounds, it generally lies on the mother's bed, who suckles the infant occasionally. The infant is rocked not side-ways but end-ways, and when it is a 
month old they put under its knees garters made of buffalo's wool which is very soft, and above the ankle bones they bind the legs with threads of the same wool for the breadth of three or four inches. And these ligatures the child wears till it be four or five years old.

The infants of the natives are white when they are born, but they soon turn brown, as they are rubbed with bear's oil and exposed to the sun. They rub them with oil, both to render their nerves more flexible, and also to prevent the flies from stinging them, as they suffer them to roll about naked upon all fours, before they are able to walk upright. They never put them upon their legs till they are a year old, and they suffer them to suck as long as they please, unless the mother prove with child, in which case she ceases to suckle.

When the boys are about twelve years of age, they give them a bow and arrows proportioned to their strength, and in order to exercise them they tie some hay, about twice as large as the fist, to the end of a pole about ten feet high. He who brings down the hay receives the prize from an old man who is always present: the best shooter is called the young warrior, the next best is called the apprentice warrior, and so on of the others, who are prompted to excel more by sentiments of honour than by blows.

As they are threatened from their most tender infancy with the resentment of the old man, if they are any ways refractory or do any mischievous tricks, which is very rare, they fear and respect him above every one else. This old man is frequently the great-grandfather, or the great-great-grandfather of the family, for those natives live to a very great age. I have seen some of them not able to walk, without having any other distemper or infirmity than old age, so that when the necessities of nature required it, or they wanted to take the air, they were obliged to be carried out of their hut, an assistance which is always readily offered to the old men. The respect paid to them by their family is so great, that they are looked upon as: the judges of all differences, and their counsels are decrees. An old man who is the head of a family is called father, even by his grand-children, and great-grand-children, 
who to distinguish their immediate father call him their true father.

If any of their young people happen to fight, which I never saw nor heard of during the whole time I resided in their neighbourhood, they threaten to put them in a hut at a great distance from their nation, as persons unworthy to live among others; and this is repeated to them so often, that if they happen to have had a battle, they take care never to have another. I have already observed that I studied them a considerable number of years; and I never could learn that there ever were any disputes or boxing matches among either their boys or men.

As the children grow up, the fathers and mothers take care each to accustom those of their own sex to the labours and exercises suited to them, and they have no great trouble to keep them employed; but it must be confessed that the girls and the women work more than the men and the boys. These last go a hunting and fishing, cut the wood, the smallest bits of which are carried home by the women; they clear the fields for corn, and hoe it; and on days when they cannot go abroad they amuse themselves with making, after their fashion, pickaxes, oars, paddles, and other instruments, which once made last a long while. The women on the other hand have their children to bring up, have to pound the maiz for the subsistence of the family, have to keep up the fire, and to make a great many utensils, which require a good deal of work, and last but a short time, such as their earthen ware, their matts, their clothes, and a thousand other things of that kind.

When the children are about ten or twelve years of age they accustom them by degrees to carry small loads, which they increase with their years. The boys are from time to time exercised in running; but they never suffer them to exhaust themselves by the length of the race, lest they should overheat themselves. The more nimble at that exercise sometimes sportfully challenges those who are more slow and heavy; but the old man who presides hinders the raillery from being carried to any excess, carefully avoiding all subjects of quarrel and dispute, on which account doubtless it is that they will never suffer them to wrestle. 
Both boys and girls are early accustomed to bathe every morning, in order to strengthen the nerves, and harden them against cold and fatigue, and likewise to teach them to swim, that they may avoid or pursue an enemy, even across a river. The boys and girls, from the time they are three years of age, are called out every morning by an old man, to go to the river; and here is some more employment for the mothers who accompany them thither to teach them to swim. Those who can swim tolerably well, make a great noise in winter by beating the water in order to frighten away the crocodiles, and keep themselves warm.

The reader will have observed that most of the labour and fatigue falls to the share of the women; but I can declare that I never heard them complain of their fatigues, unless of the trouble their children gave them, which complaint arose as much from maternal affection, as from any attention that the children required. The girls from their infancy have it instilled into them, that if they are sluttish or unhandy they will have none but a dull aukward fellow for their husband; I observed in all the nations I visited, that this threatening was never lost upon the young girls.

I would not have it thought however, that the young men are altogether idle. Their occupations indeed are not of such a long continuance; but they are much more laborious. As the men have occasion for more strength, reason requires that they should not exhaust themselves in their youth; but at the same time they are not exempted from those exercises that fit them for war and hunting. The children are educated without blows; and the body is left at full liberty to grow, and to form and strengthen itself with their years. The youths accompany the men in hunting, in order to learn the wiles and tricks necessary to be practised in the field, and accustom themselves to suffering and patience. When they are full grown men, they dress the field or waste land, and prepare it to receive the seed; they go to war or hunting, dress the skins, cut the wood, make their bows and arrows, and assist each other in building their huts.

They have still I allow a great deal of more spare time than the women; but this is not all thrown away. As these 
people have not the assistance of writing, they are obliged to have recourse to tradition, in order to preserve the remembrance of any remarkable transactions; and this tradition cannot be learned but by frequent repetitions, consequently many of the youths are often employed in hearing the old men narrate the history of their ancestors, which is thus transmitted from generation to generation. In order to preserve their traditions pure and uncorrupt, they are careful not to deliver them indifferently to all their young people, but teach them only to those young men of whom they have the best opinion.

\section{SECTION II.}

Of the language, government, religion, ceremonies, and feasts of the natives.

DURING my residence among the Natchez I contracted an intimate friendship, not only with the chiefs or guardians of the temple, but with the Great Sun, or the sovereign of the nation, and his brother the Stung Serpent, the chief of the warriors; and by my great intimacy with them, and the respect I acquired among the people, I easily learned the peculiar language of the nation.

This language is easy in the pronunciation, and expressive in the terms. The natives, like the Orientals, speak much in a figurative stile, the Natchez in particular more than any other people of Louisiana. They have two languages, that of the nobles and that of the people, and both are very copious. I will give two or three examples to shew the difference of these two languages. When I call one of the common people, I say to him aquenan, that is, hark ye: if, on the other hand, I want to speak to a Sun, or one of their nobles, I say to him, magani, which signifies, hark ye. If one of the common people call at my house, I say to him, tachte-cabanacte, are you there, or I am glad to see you, which is equivalent to our goodmorrow. I express the same thing to a Sun by the word apapegouaiché. Again, according to their custom, I say to one of the common people, petchi, sit you down; but to a Sun, when I desire him to sit down, I say, caham. The two languages are 
nearly the same in all other respects; for the difference of expression seems only to take place in matters relating to the persons of the Suns and nobles, in distinction from those of the people.

Tho' the women speak the same language with the men, yet; in their manner of pronunciation, they soften and smooth the words, whereas the speech of the men is more grave and serious. The French, by chiefly frequenting the women, contracted their manner of speaking, which was ridiculed as an effeminacy by the women, as well as the men, among the natives.

From my conversations with the chief of the guardians of the temple, I discovered that they acknowledged a supreme being, whom they called Coyococop-Chill, or Great Spirit. The Spirit infinitely great, or the Spirit by way of excellence. The word chill, in their language, signifies the most superlative degree of perfection, and is added by them to the word which signifies fire, when they want to mention the Sun; thus Oua is fire, and Oua-chill is the supreme fire, or the Sun; therefore, by the word Coyocop-Chill they mean a spirit that surpasses other spirits as much as the sun does common fire.

"God," according to the definition of the guardian of the temple, "was so great and powerful, that, in comparison with him, all other things were as nothing; he had made all that we see, all that we can see, and all that we cannot see; he was so good, that he could not do ill to any one, even if he had a mind to it. They believe that God had made all things by his will; that nevertheless the little spirits, who are his servants, might, by his orders, have made many excellent works in the universe, which we admire; but that God himself had formed man with his own hands."

The guardian added, that they named those little spirits, Coyocop-techou, that is, a free servant, but as submissive and as respectful as a slave; that those spirits were always present before God, ready to execute his pleasure with an extreme diligence; that the air was filled with other spirits, some good some wicked; and that the latter had a chief, who was more 
wicked than them all; that God had found him so wicked, that he had bound him for ever, so that the other spirits of the air no longer did so much harm, especially when they were by prayers entreated not to do it; for it is one of the religious customs of those people to invoke the spirits of the air for rain or fine weather, according as each is needed. I have seen the Great Sun fast for nine days together, eating nothing but maizcorn, without meat or fish, drinking nothing but water, and abstaining from the company of his wives during the whole time. He underwent this rigorous fast out of complaisance to some Frenchmen, who had been complaining that it had not rained for a long time. Those inconsiderate people had not remarked, that notwithstanding the want of rain, the fruits of the earth had not suffered, as the dew is so plentiful in summer as fully to supply that deficiency.

The guardian of the temple having told me that God had made man with his own hands, I asked him if he knew how that was done. He answered, "that God had kneaded some clay, such as that which potters use, and had made it into a little man; and that after examining it, and finding it well formed, he blew up his work, and forthwith that little man had life, grew, acted, walked, and found himself a man perfectly well shaped." As he made no mention of the woman, I asked him how he believed she was made; he told me, "that probably in the same manner as the man; that their antient speech made no mention of any difference, only told them that the man was made first, and was the strongest and most courageous, because he was to be the head and support of the woman, who was made to be his companion."

Here I did not omit to rectify his notions on the subjects we had been talking about, and to give him those just ideas which religion teaches us, and the sacred writings have transmitted to us. He hearkened to me with great attention, and promised to repeat all that I had told him to the old men of his nation, who certainly would not forget it; adding, that we were very happy in being able to retain the knowledge of such fine things by means of the speaking cloth, so they name books and manuscripts. 
I next proceeded to ask him, who had taught them to build a temple; whence had they their eternal fire, which they preserved with so much care; and who was the person that first instituted their feasts? He replied, "The charge I am entrusted with obliges me to know all these things you ask of me; I will therefore satisfy you: hearken to me. A great number of years ago there appeared among us a man and his wife, who came down from the sun. Not that we believe that the sun had a wife who bore him children, or that these were the descendants of the sun; but when they first appeared among us they were so bright and luminous that we had no difficulty to believe that they came down from the sun. This man told us, that having seen from on high that we did not govern ourselves well; that we had no master; that each of us had presumption enough to think himself capable of governing others, while he could not even conduct himself; he had thought fit to come down among us to teach us to live better.

"He moreover told us, that in order to live in peace among ourselves, and to please the supreme Spirit, we must indispensably observe the following points; we must never kill any one but in defence of our own lives; we must never know any other woman besides our own; we must never take any thing that belongs to another; we must never lye nor get drunk; we must not be avaricious, but must give liberally, and with joy, part of what we have to others who are in want, and generously share our subsistence with those who are in need of it."

"The words of this man deeply affected us, for he spoke them with authority, and he procured the respect even of the old men themselves, tho' he reprehended them as freely as the rest. Next day we offered to acknowledge him as our sovereign. He at first refused, saying that he should not be obeyed, and that the disobedient would infallibly die; but at length he accepted the offer that was made him on the following condition :

"That we would go and inhabit another country, better than that in which we were, which he would shew us; that we would afterwards live conformable to the instructions he had given us; that we would promise never to acknowledge any 
other sovereigns but him and his descendants; that the nobility should be perpetuated by the women after this manner; if I, said he, have male and female children, they being brothers and sisters cannot marry together; the eldest boy may chuse a wife from among the people, but his sons shall be only nobles; the children of the eldest girl, on the other hand, shall be princes and princesses, and her eldest son be sovereign; but her eldest daughter be the mother of the next sovereign, even tho' she should marry one of the common people; and, in defect of the eldest daughter, the next female relation to the person reigning shall be the mother of the future sovereign; the sons of the sovereign and princes shall lose their rank, but the daughters shall preserve theirs."

"He then told us, that in order to preserve the excellent precepts he had given us, it was necessary to build a temple, into which it should be lawful for none but the princes and princesses to enter, to speak to the Spirit. That in the temple they should eternally preserve a fire, which he would bring down from the sun, from whence he himself had descended, that the wood with which the fire was supplied should be pure wood without bark; that eight wise men of the nation should be chosen for guarding the fire night and day; that those eight men should have a chief, who should see them do their duty, and that if any of them failed in it he should be put to death. He likewise ordered another temple to be built in a distant part of our nation, which was then very populous, and the eternal fire to be kept there also, that in case it should be extinguished in the one it might be brought from the other; in which case, till it was again lighted, the nation would be afflicted with a great mortality."

"Our nation having consented to these conditions, he agreed to be our sovereign; and in presence of all the people he brought down the fire from the sun, upon some wood of the walnut-tree which he had prepared, which fire was deposited in both the temples. He lived a long time, and saw his children's children. To conclude, he instituted our feasts such as you see them."

The Natchez have neither sacrifices, libations, nor offerings: their whole worship consists in preserving the eternal 
fire, and this the Great Sun watches over with a peculiar attention. The Sun, who reigned when I was in the country, was extremely solicitous about it, and visited the temple every day. His vigilance had been awakened by a terrible hurricane which some years before had happened in the country, and was looked upon as an extraordinary event, the air being generally clear and serene in that climate. If to that calamity should be joined the extinction of the eternal fire, he was apprehensive their whole nation would be destroyed.

One day, when the Great Sun called upon me, he gave me an account of a dreadful calamity that had formerly befallen the nation of the Natchez, in consequence, as he believed, of the extinction of the eternal fire. He introduced his account in the following manner: "Our nation was formerly very numerous and very powerful; it extended more than twelve days journey from east to west, and more than fifteen from south to north. We reckoned then 500 Suns, and you may judge by that what was the number of the nobles, of the people of rank, and the common people. Now in times past it happened, that one of the two guardians, who were upon duty in the temple, left it on some business, and the other fell asleep, and suffered the fire to go out. When he awaked and saw that he had incurred the penalty of death, he went and got some profane fire, as tho' he had been going to light his pipe, and with that he renewed the eternal fire. His transgression was by that means concealed; but a dreadful mortality immediately ensued, and raged for four years, during which many Suns and an infinite number of the people died.

The guardian at length sickened, and found himself dying, upon which he sent for the Great Sun, and confessed the heinous crime he had been guilty of. The old men were immediately assembled, and, by their advice, fire being snatched from the other temple, and brought into this, the mortality quickly ceased." Upon my asking him what he meant by "snatching the fire," he replied, "that it must always be brought away by violence, and that some blood must be shed, unless some tree on the road was set on fire by lightning, and 
then the fire might be brought from thence; but that the fire of the sun was always preferable.

It is impossible to express his astonishment when I told him, that it was a trifling matter to bring down fire from the sun, and that I had it in my power to do it whenever I pleased. As he was extremely desirous to see me perform that seeming miracle, I took the smallest of two burning glasses which I had brought from France, and placing some dry punk (or agaric) upon a chip of wood, I drew the focus of the glass upon it, and with a tone of authority pronounced the word Caheuch, that is, come, as tho' I had been commanding the fire to come down. The punk immediately smoking, I blew a little and made it flame to the utter astonishment of the Great Sun and his whole retinue, some of whom stood trembling with amazement and religious awe. The prince himself could not help exclaiming, "Ah, what an extraordinary thing is here!" I confirmed him in his idea, by telling him, that I greatly loved and esteemed that useful instrument, as it was most valuable, and was given to me by my grandfather, who was a very learned man.

Upon his asking me, if another man could do the same thing with that instrument that he had seen me do, I told him that every man might do it, and I encouraged him to make the experiment himself. I accordingly put the glass in his hand, and leading it with mine over another piece of agaric, I desired him to pronounce the word Caheuch, which he did, but with a very faint and diffident tone; nevertheless, to his great amazement, he saw the agaric begin to smoke, which so confounded him that he dropt both the chip on which it was laid and the glass out of his hands, crying out, "Ah, what a miracle!"

Their curiosity being now fully raised, they held a consultation in my yard, and resolved to purchase at any rate my wonderful glass, which would prevent any future mortality in their nation, in consequence of the extinction of the eternal fire. I, in the mean time, had gone out to my field, as if about some business; but in reality to have a hearty laugh at the comical scene which I had just occasioned. Upon my return the Great Sun entered my apartment with me, and laying his hand upon mine, told me, that tho' he loved all the French, he 
was more my friend than of any of the rest, because most of the French carried all their understanding upon their tongue; but that I carried mine in my whole head and my whole body. After this preamble he offered to bargain for my glass, and desired me to set what value I pleased upon it, adding that he would not only cause the price to be paid by all the families of the nation, but would declare to them that they lay under an obligation to me for giving up to them a thing which saved them from a general mortality. I replied, that tho' I bore his whole nation in my heart, yet nothing made me part with my glass, but my affection for him and his brother; that, besides, I asked nothing in return but things necessary for my subsistence, such as corn, fowls, game, and fish, when they brought him any of these. He offered me twenty barrels of maiz, of 150 pounds each, twenty fowls, twenty turkies, and told me that he would send me game and fish every time his warriors brought him any, and his promise was punctually fulfilled. $\mathrm{He}$ engaged likewise not to speak any thing about it to the Frenchmen, lest they should be angry with me for parting with an instrument of so great a value. Next day the glass was tried before a general assembly of all the Suns, both men and women, the nobles, and the men of rank, who all met together at the temple; and the same effect being produced as the day before, the bargain was ratified; but it was resolved not to mention the affair to the common people, who, from their curiosity to know the secrets of their court, were assembled in great numbers not far from the temple, but only to tell them, that the whole nation of the Natchez were under great obligations to me.

The Natchez are brought up in a most perfect submission to their sovereign; the authority which their princes exercise over them is absolutely despotic, and can be compared to nothing but that of the first Ottoman emperors. Like these, the Great Sun is absolute master of the lives and estates of his subjects, which he disposes of at his pleasure, his will being the only law; but he has this singular advantage over the Ottoman princes, that he has no occasion to fear any seditious tumults, or any conspiracy against his person. If he orders a man guilty of a capital crime to be put to death, the criminal 
neither supplicates, nor procures intercession to be made for his life, nor attempts to run away. The order of the sovereign is executed on the spot, and nobody murmurs. But however absolute the authority of the Great Sun may be, and although a number of warriors and others attach themselves to him, to serve him, to follow him wherever he goes, and to hunt for him, yet he raises no stated impositions; and what he receives from those people appears given, not so much as a right due, as a voluntary homage, and a testimony of their love and gratitude.

The Natchez begin their year in the month of March, as was the practice a long time in Europe, and divide it into thirteen moons. At every new moon they celebrate a feast, which takes its name from the principal fruits reaped in the preceding moon, or from animals that are then usually hunted. I shall give an account of one or two of these feasts as concisely as I can.

The first moon is called that of the Deer, and begins their new year, which is celebrated by them with universal joy, and is at the same time an anniversary memorial of one of the most interesting events in their history. In former times a Great Sun, upon hearing a sudden tumult in his village, had left his hut in a great hurry, in order to appease it, and fell into the hands of his enemies; but was quickly after rescued by his warriors, who repulsed the invaders, and put them to flight. In order to preserve the remembrance of this honourable exploit, the warriors divide themselves into two bodies, distinguished from each other by the colour of their feathers. One of these bodies represents the invaders, and after raising loud shouts and cries, seize the Great Sun, who comes out of his hut undressed, and rubbing his eyes, as though he were just awake. The Great Sun defends himself intrepidly with a wooden tomahawk, and lays a great many of his enemies upon the ground, without however giving them a single blow, for he only seems to touch them with his weapon. In the mean time the other party come out of their ambuscade, attack the invaders, and, after fighting with them for some time, rescue their prince, and drive them into a wood, which is represented by an arbour 
made of canes. During the whole time of the skirmish, the parties keep up the war-cry, or the cry of terror, as each of them seem to be victors or vanquished. The Great Sun is brought back to his hut in a triumphant manner; and the old men, women, and children, who were spectators of the engagement, rend the sky with their joyful acclamations. The Great Sun continues in his hut about half an hour, to repose himself after his great fatigues, which are such that an actor of thirty years of age would with difficulty have supported them, and he however, when I saw this feast, was above ninety. He then makes his appearance again to the people, who salute him with loud acclamations, which cease upon his proceeding towards the temple. When he is arrived in the middle of the court before the temple, he makes several gesticulations, then stretches out his arms horizontally, and remains in that posture motion. less as a statute for half an hour. $\mathrm{He}$ is then relieved by the master of the ceremonies, who places himself in the same attitude, and half an hour after is relieved by the great chief of war, who remains as long in the same posture. When this ceremony is over, the Great Sun, who, when he was relieved, had returned to his hut, appears again before the people in the ornaments of his dignity, is placed upon his throne, which is a large stool with four feet cut out of one piece of wood, has a fine buffalo's skin thrown over his shoulders, and several furs laid upon his feet, and receives various presents from the women, who all the while continue to express their joy by their shouts and acclamations. Strangers are then invited to dine with the Great Sun, and in the evening there is a dance in his hut, which is about thirty feet square, and twenty feet $h$ igh, and like the temple is built upon a mount of earth, about eight feet high, and sixty feet over on the surface.

The second moon, which answers to our April, is called the Strawberry moon, as that fruit abounds then in great quantities.

The third moon is that of the Small Corn. This moon is often impatiently looked for, their crop of large corn never sufficing to nourish them from one harvest to another. 

June.

The fourth is that of Water-melons, and answers to our

The fifth moon is that of the Fishes: in this month also they gather grapes, if the birds have suffered them to ripen.

The sixth, which answers to our August, is that of the Mulberries. At this feast they likewise carry fowls to the Great Sun.

The seventh, which is that of Maiz, or Great Corn. This feast is beyond dispute the most solemn of all. It principally consists in eating in common, and in a religious manner, of new corn, which had been sown expressly with that design, with suitable ceremonies. This corn is sown upon a spot of ground never before cultivated; which ground is dressed and prepared by the warriors alone, who also are the only persons that sow the corn, weed it, reap it, and gather it. When this corn is near ripe, the warriors fix on a place proper for the general feast, and close adjoining to that they form a round granary, the bottom and sides of which are of cane; this they fill with the corn, and when they have finished the harvest, and covered the granary, they acquaint the Great Sun, who appoints the day for the general feast. Some days before the feast, they build huts for the Great Sun, and for all the other families, round the granary, that of the Great Sun being raised upon a mount of earth about two feet high. On the feast-day the whole nation set out from their village at sun-rising, leaving behind only the aged and infirm that are not able to travel, and a few warriors, who are to carry the Great Sun on a litter upon their shoulders. The seat of this litter is covered with several deer skins, and to its four sides are fastened four bars which cross each other, and are supported by eight men, who at every hundred paces transfer their burden to eight other men, and thus successively transport it to the place where the feast is celebrated, which may be near two miles from the village. About nine o'clock the Great Sun comes out of his hut dressed in the ornaments of his dignity, and being placed in his litter, which has a canopy at the head formed of flowers, he is carried in a few minutes to the sacred granary, shouts of 
joy re-echoing on all sides. Before he alights he makes the tour of the whole place deliberately, and when he comes before the corn, he salutes it thrice with the words, hoo, hoo, hoo, lengthened and pronounced respectfully. The salutation is repeated by the whole nation, who pronounce the word hoo nine times distinctly, and at the ninth time he alights and places himself on his throne.

Immediately after they light a fire by rubbing two pieces of wood violently against each other, and when every thing is prepared for dressing the corn, the chief of war, accompanied by the warriors belonging to each family, presents himself before the throne, and addresses the Sun in these words, "speak, for I hear thee." The sovereign then rises up, bows towards the four quarters of the world, and advancing to the granary, lifts his eyes and hands to heaven, and says, "Give us corn:" upon which the great chief of war, the princes and princesses, and all the men, thank him separately, by pronouncing the word hoo. The corn is then distributed, first to the female Suns, and then to all the women, who run with it to their huts, and dress it with the utmost dispatch. When the corn is dressed in all the huts, a plate of it is put into the hands of the Great Sun, who presents it to the four quarters of the world, and then says to the chief of war, eat; upon this signal the warriors begin to eat in all the huts; after them the boys of whatever age, excepting those who are on the breast; and last of all the women. When the warriors have finished their repast, they form themselves into two choirs before the huts, and sing war songs for half an hour; after which the chief of war, and all the warriors in succession, recount their brave exploits, and mention, in a boasting manner, the number of enemies they have slain. The youths are next allowed to harangue, and each tells in the best manner he can, not what he has done, but what he intends to do; and if his discourse merits approbation, he is answered by a general hoo; if not, the warriors hang down their heads and are silent.

This great solemnity is concluded with a general dance by torch-light. Upwards of two hundred torches of dried canes, each of the thickness of a child, are lighted round the place, 


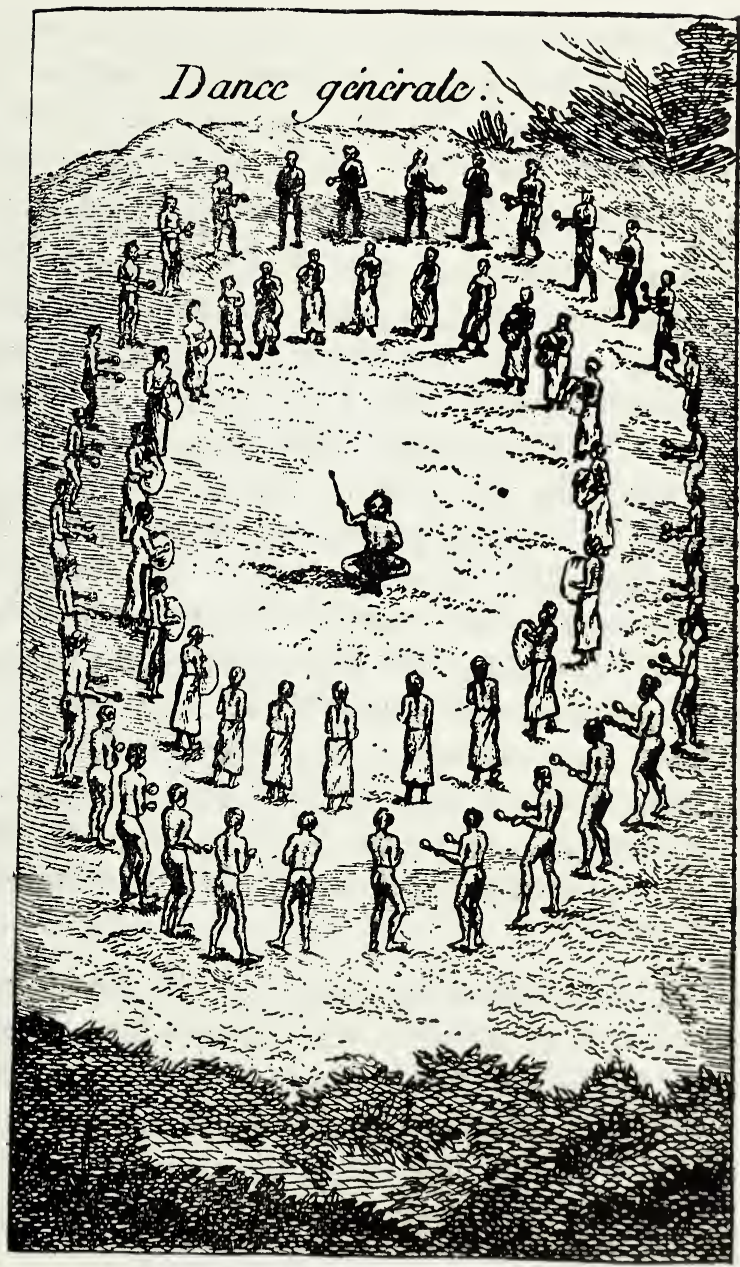

Dance of the Natchez Indians

where the men and women often continue dancing till daylight; and the following is the disposition of their dance. A man places himself on the ground with a pot covered with a deer-skin, in the manner of a drum, to beat time to the dances; round him the women form themselves into a circle, not joining hands, but at some distance from each other; and they are inclosed by the men in another circle, who have in each hand a chichicois, or calabash, with a stick thrust through it to serve for a handle. When the dance begins, the women move round 
the men in the centre, from left to right, and the men contrariwise from right to left, and they sometimes narrow and sometimes widen their circles. In this manner the dance continues without intermission the whole night, new performers successively taking the place of those who are wearied and fatigued.

Next morning no person is seen abroad before the Great Sun comes out of his hut, which is generally about nine o'clock, and then upon signal made by the drum, the warriors make their appearance distinguished into two troops, by the feathers which they wear on their heads. One of these troops is headed by the Great Sun, and the other by the chief of war, who begin a new diversion by tossing a ball of deer-skin stuffed with Spanish beard from the one to the other. The warriors quickly take part in the sport, and a violent contest ensues which of the two parties shall drive the ball to the hut of the opposite chief. The diversion generally lasts two hours, and the victors are allowed to wear the feathers of superiority till the following year, or till the next time they play at the ball. After this the warriors perform the war dance; and last of all they go and bathe; an exercise which they are very fond of when they are heated or fatigued.

The rest of that day is employed as the preceding; for the feasts holds as long as any of the corn remains. When it is all eat up, the Great Sun is carried back in his litter, and they all return to the village, after which he sends the warriors to hunt both for themselves and him.

The eighth moon is that of Turkies, and answers to our October.

The ninth moon is that of the Buffalo; and it is then they go to hunt that animal. Having discovered whereabouts the herd feeds, they go out in a body to hunt them. Young and old, girls and married women, except those who are with child, are all of the party, for there is generally work for them all. Some nations are a little later in going out to this hunting, that they may find the cows fatter, and the herds more numerous.

The tenth moon is that of Bears; at this time of hunting the feasts are not so grand and solemn, because great part of the nations are accompanying the hunters in their expeditions. 
The eleventh answers to our January, and is named as Cold-meal Moon. The twelfth is that of Chesnuts. That fruit has been gathered long before, nevertheless it gives its name to this moon.

Lastly, the thirteenth is that of Walnuts, and it is added to compleat the year. It is then they break the nuts to make bread of them by mixing with them the flour of Maiz.

The feasts which I saw celebrated in the chief village of the Natchez, which is the residence of the Great Sun, are celebrated in the same manner in all the villages of the nation, which are each governed by a Sun, who is subordinate to the Great Sun, and acknowledge his absolute authority.

It is not to be conceived how exact these people are in assigning the pre-eminence to the men. In every assembly, whether of the whole nation in general, or of several families together, or of one family, the youngest boys have the preference to the women of the most advanced age; and at their meals, when their food is distributed, none is presented to the women, till all the males have received their share, so that a boy of two years old is served before his mother.

The women being always employed, without ever being diverted from their duty, or seduced by the gallantries of lovers, never think of objecting to the propriety of a custom, in which they have been constantly brought up. Never having seen any example that contradicted it, they have not the least idea of varying from it. Thus being submissive from the habit, as well as from reason, they, by their docility, maintain that peace in their families, which they find established upon entering them. 


\section{SECTION III. \\ Of their Marriages, and Distinction of Ranks.}

PATERnal authority, as I have elsewhere observed, is not less sacred and inviolable than the pre-eminence of the men. It still subsists among the Natchez, such as it was in the first ages of the world. The children belong to the father, and while he lives they are under his power. They live with him, they, their wives, and their children; the same hut contains the whole family. The old man alone commands there, and nothing but death puts an end to his empire. As these people have seldom or rather never any differences among them, the paternal authority appears in nothing more conspicuous than in the marriages.

When the boys and girls arrive at the perfect age of puberty, they visit each other familiarly, and are suffered so to do. The girls, sensible that they will be no longer mistresses of their heart, when once they are married, know how to dispose of it to advantage, and form their wardrobe by the sale of their favours; for there, as well as in other countries, nothing for nothing. The lover, far from having any thing to object to this, on the contrary, rates the merit of his future spouse, in proportion to the fruits she has produced. But when they are married they have no longer any intrigues, neither the husband nor the wife, because their heart is no longer their own. They may divorce their wives; it is, however, so rare to see the man and wife part, that during the eight years I lived in their neighbourhood, I knew but one example of it, and then each took with them the children of their own sex.

If a young man has obtained a girl's consent, and they desire to marry, it is not their fathers, and much less their mothers, or male or female relations who take upon them to conclude the match; it is the heads of the two families alone, who are usually great-grandfathers, and sometimes more. These two old men have an interview, in which, after the young man has formally made a demand of the girl, they examine if there be any relation between the two parties, and if any, what de- 
gree it is ; for they do not marry within the third degree. Notwithstanding this interview, and the two parties be found not within the prohibited degrees, yet if the proposed wife be disagreeable to the father, grandfather, \&c. of the husband, the match is never concluded. On the other hand, ambition, avarice, and the other passions, so common with us, never stifle in the breasts of the fathers those dictates of nature, which make us desire to see ourselves perpetuated in our offspring, nor influence them to thwart their children, improperly, and much less to force their inclinations. By an admirable harmony, very worthy of our imitation, they only marry those who love one another, and those who love one another, are only married when their parents agree to it. It is rare for young men to marry before they be five-and-twenty. Till they arrive at that age they are looked upon as too weak, without understanding and experience.

When the marriage-day is once fixed, preparations are made for it both by the men and women; the men go a hunting, and the women prepare the maiz, and deck out the young man's cabin to the best of their power. On the wedding-day the old man on the part of the girl leaves his hut, and conducts the bride to the hut of the bridegroom; his whole family follow him in order and silence; those who are inclined to laugh or be merry, indulging themselves only in a smile.

He finds before the other hut all the relations of the bridegroom, who receive and salute him with their usual expression of congratulation, namely, hoo, hoo, repeated several times. When he enters the hut, the old man on the part of the bridegroom says to him in their language, are you there? to which he answers, yes. He is next desired to sit down, and then not a word passes for near ten minutes, it being one of their prudent customs to suffer a guest to rest himself a little after his arrival, before they begin a conversation; and besides, they look upon the time spent in compliments as thrown away.

After both the old men are fully rested, they rise, and the bridegroom and bride appearing before them, they ask them, if they love each other? and if they are willing to take one another for man and wife? observing to them at the same time, 
that they ought not to marry unless they propose to live amicably together; that nobody forces them, and that as they are each other's free choice, they will be thrust out of the family if they do not live in peace. After this remonstrance the father of the bridegroom delivers the present which his son is to make into his hands, the bride's father at the same time placing himself by her side. The bridegroom then addresses the bride; "Will you have me for your husband?" she answers, "Most willingly, and it gives me joy; love me, as well as I love you; for I love, and ever will love none but you." At these words the bridegroom covers the head of the bride with the present which he received from his father, and says to her, "I love you, and have therefore taken you for my wife, and this I give to your parents, to purchase you." He then gives the present to the bride's father.

The husband wears a tuft of feathers fastened to his hair, which is in the form of a cue, and hangs over his left ear, to which is fastened a sprig of oak with the leaves on, and in his left hand he bears a bow and arrows. The young wife bears in her left hand a small branch of laurel, and in her right a stalk of maiz, which was delivered to her by her mother at the time she received the present from her husband. This stalk she presents to her husband, who takes it from her with his right hand, and says, "I am your husband;" she answers, and "I am your wife." They then shake hands reciprocally with each other's relations; after which he leads her towards the bed, and says, "There is our bed, keep it tight;" which is as much as to say, do not defile the nuptial bed.

The marriage ceremony being thus concluded, the bridegroom and the bride, with their friends, sit down to a repast, and in the evening they begin their dances, which continue often till day-light.

The nation of the Natchez is composed of nobility and common people. The common people are named in their language Miche-Miche-Quipy, that is, Stinkards; a name however which gives them great offense, and which it is proper to avoid pronouncing before them, as it would not fail to put them into a very bad humour. The common people are to the 
last degree submissive to the nobility, who are divided into Suns, nobles, and men of rank.

The Suns are the descendants of the man and woman who pretended to have come down from the sun. Among the other laws they gave to the Natchez, they ordained that their race should always be distinguished from the bulk of the nation, and that none of them should ever be put to death upon any account. They established likewise another usage which is found among no other people, except a nation of Scythians mentioned by Herodotus. They ordained that nobility should only be transmitted by the women. Their male and female children were equally named Suns, and regarded as such, but with this difference, that the males enjoyed this privilege only in their own person, and during their own lives. Their children had only the title of nobles, and the male children of those nobles were only men of rank. Those men of rank, however, if they distinguished themselves by their war-like exploits, might raise themselves again to the rank of nobles; but their children became only men of rank, and the children of those men of rank, as well as of the others, were confounded with the common people, and classed among the Stinkards. Thus as these people are very long-lived, and frequently see the fourth generation, it often happens that a Sun sees some of his posterity among the Stinkards; but they are at great pains to conceal this degradation of their race, especially from strangers, and almost totally disown those great-grand children; for when they speak of them they only say, they are dear to them. It is otherwise with the female posterity of the Suns, for they continue through all generations to enjoy their rank. The descendants of the Suns being pretty numerous, it might be expected that those who are out of the prohibited degrees might intermarry, rather than ally with the Stinkards; but a most barbarous custom obliges them to their mis-alliances. When any of the Suns, either male or female, die, their law ordains that the husband or wife of the Sun shall be put to death on the day of the interment of the deceased: now as another law prohibits the issue of the Suns from being put to death, it is therefore impossible for the descendants of the Suns to match with each other. 
Whether it be that they are tired of this law, or that they with their Suns descended of French blood, I shall not determine; but the wife of the Great Sun came one day to visit me so early in the morning that I was not got out of bed. She was accompanied with her only daughter, a girl between fourteen and fifteen years of age, handsome and well shaped; but she only sent in her own name by my slave; so that without getting up, I made no scruple of desiring her to come in. When her daughter appeared I was not a little surprized; but I shook hands with them both, and desired them to sit down. The daughter sat down on the foot of my bed, and kept her eyes continually fixed on me, while the mother addressed herself to me in the most serious and pathetic tone. After some compliments to me, and commendations of our customs and manners, she condemned the barbarous usages that prevailed among themselves, and ended with proposing me as a husband for her daughter, that I might have it in my power to civilize their nation by abolishing their inhuman customs, and introducing those of the French. As I foresaw the danger of such an alliance, which would be opposed by the whole nation of the Natchez, and at the same time was sensible that the resentment of a slighted woman is very formidable, I returned her such an answer as might shew my great respect for her daughter, and prevent her from making the same application to some brainless Frenchman, who, by accepting the offer, might expose the French settlement to some disastrous event. I told her that her daughter was handsome, and pleased me much, as she had a good heart, and a well turned mind; but the laws we received from the Great Spirit, forbad us to marry women who did not pray; and that those Frenchmen who lived with their daughters took them only for a time; but it was not proper that the daughter of the Great Sun should be disposed of in that manner. The mother acquiesced in my reasons; but when they took their leave I perceived plainly that the daughter was far from being satisfied. I never saw her from that day forwards; and I heard she was soon after married to another.

From this relation the reader may perceive that there needs nothing but prudence and good sense to persuade those people 
to what is reasonable, and to preserve their friendship without interruption. We may safely affirm that the differences we have had with them have been more owing to the French than to them. When they are treated insolently or oppressively, they have no less sensibility of injuries than others. If those who have occasion to live among them, will but have sentiments of humanity, they will in them meet with men.

\section{SECTION IV.}

Of the Temples, Tombs, Burials, and other religious Ceremonies of the People of Louisiana.

I Shall now proceed to give some account of the customs that prevail in general among all the nations of North America; and these have a great resemblance to each other, as there is hardly any difference in the manner of thinking and acting among the several nations. These people have no religion expressed by any external worship. The strongest evidences that we discover of their having any religion at all, are their temples, and the eternal fire therein kept up by some of them. Some of them indeed do not keep up the eternal fire, and have turned their temples into charnel-houses.

However, all those people, without exception, acknowledge a supreme Being, but they never on any account address their prayers to him, from their fixt belief that God, whom they call the Great Spirit, is so good, that he cannot do evil, whatever provocation he may have. They believe the existence of two Great Spirits, a good and a bad. They do not, as I have said, invoke the Good Spirit; but they pray to the bad, in order to avert from their persons and possessions the evils which he might inflict upon them. They pray to the evil spirit, not because they think him almighty; for it is the Good Spirit whom they believe so; but because, according to them, he governs the air, the seasons, the rain, the fine weather, and all that may benefit or hurt the productions of the earth.

They are very superstitious in respect to the flight of birds, and the passage of some animals that are seldom seen in their country. They are much inclined to hear and believe 
diviners, especially in regard to discovering things to come; and they are kept in their errors by the Jongleurs, who find their account in them.

The natives have all the same manner of bringing up their children, and are in general well shaped, and their limbs are justly proportioned. The Chicasaws are the most fierce and arrogant, which they undoubtedly owe to their frequent intercourse with the English of Carolina. They are brave; a disposition they may have inherited as the remains of that martial spirit that prompted them to invade their neighbouring nations, by which they themselves were at length greatly weakened. All the nations on the north of the colony are likewise brave, but they are more humane than the Chicasaws, and have not their high-spirited pride. All these nations of the north, and all those of Louisiana, have been inviolably attached to us ever since our establishment in this colony. The misfortune of the Natchez, who, without dispute, were the finest of all those nations, and who loved us, ought not in the least to lessen our sentiments of those people, who are in general distinguished for their natural goodness of character. All those nations are prudent, and speak little; they are sober in their diet, but they are passionately fond of brandy, though they are singular in never tasting any wine, and neither know nor care to learn any composition of liquors. In their meals they content themselves with maiz prepared various ways, and sometimes they use fish and flesh. The meat that they eat is chiefly recommended to them for being wholesome; and therefore I have conjectured that dog's flesh, for which we have such an aversion, must however be as good as it is beautiful, since they rate it so highly as to use it by way of preference in their feasts of ceremony. They eat no young game, as they find plenty of the largest size, and do not think delicacy of taste alone any recommendation; and therefore, in general, they would not taste our ragouts, but, condemning them as unwholesome, prefer to them gruel made of maiz, called in the colony Sagamity.

The Chactaws are the only ugly people among all the nations in Louisiana; which is chiefly owing to the fat with which 
they rub their skin and their hair, and to their manner of defending themselves against the moskitos, which they keep of by lighting fires of fir-wood, and standing in the smoke.

Although all the people of Louisiana have nearly the same usages and customs, yet as any nation is more or less populous, it has proportionally more or fewer ceremonies. Thus when the French first arrived in the colony, several nations kept up the eternal fire, and observed other religious ceremonies, which they have now disused, since their numbers have been greatly diminished. Many of them still continue to have temples, but the common people never enter these, nor strangers, unless peculiarly favoured by the nation. As I was an intimate friend of the sovereign of the Natchez, he shewed me their temple, which is about thirty feet square, and stands upon an artificial mount about eight feet high, by the side of a small river. The mount slopes insensibly from the main front, which is northwards, but on the other sides it is somewhat steeper. The four corners of the temple consist of four posts, about a foot and an half diameter, and ten feet high, each made of the heart of the cypress tree, which is incorruptible. The side-posts are of the same wood, but only about a foot square; and the walls are of mud, about nine inches thick; so that in the inside there is a hollow between every post. The inner space is divided from east to west into two apartments one of which is twice as large as the other. In the largest apartment the eternal fire is kept, and there is likewise a table or altar in it, about four feet high, six long, and two broad. Upon this table lie the bones of the late Great Sun in a coffin of canes very neatly made. In the inner apartment, which is very dark, as it receives no light but from the door of communication, I could meet with nothing but two boards, on which were placed some things like small toys, which I had not light to peruse. The roof is in the form of a pavilion, and very neat both within and without, and on the top of it are placed three wooden birds, twice as large as a goose, with their heads turned towards the east. The corner and side-posts, as has been mentioned, rise above the earth ten feet high, and it is said they are as much sunk under ground; it cannot therefore but appear surprising how the natives could transport such large beams, fashion them, and raise them 
upright, when we know of no machines they had for that purpose. Besides the eight guardians of the temple, two of whom are always on watch, and the chief of those guardians, there also belongs to the service of the temple a master of the ceremonies, who is also master of the mysteries; since, according to them, he converses very familiarly with the Spirit. Above all these persons is the Great Sun, who is at the same time chief priest and sovereign of the nation. The temples of some of the nations of Louisiana are very mean, and one would often be apt to mistake them for the huts of private persons, but to those who are acquainted with their manners, they are easily distinguishable, as they have always before the door two posts formed like the ancient Termini, that is, having the upper part cut into the shape of a man's head. The door of the temple, which is pretty weighty, is placed between the wall and those two posts, so that children may not be able to remove it, to go and play in the temple. The private huts have also posts before their doors, but these are never formed like Termini.

None of the nations of Louisiana are acquainted with the custom of burning their dead, which was practised by the Greeks and Romans; nor with that of the Egyptians, who studied to preserve them to perpetuity. The different American nations have a most religious attention for their dead, and each have some peculiar customs in respect to them; but all of them either inter them, or place them in tombs, and carefully carry victuals to them for some time. These tombs are either within their temples, or close adjoining to them, or in their neighbourhood. They are raised about three feet above the earth, and rest upon four pillars, which are forked stakes fixed fast in the ground. The tomb, or rather bier, is about eight feet long, and a foot and a half broad; and after the body is placed upon it, a kind of basket-work of twigs is wove round it, and covered with mud, an opening being left at the head for placing the victuals that are presented to the dead person. When the body is all rotted but the bones, these are taken out of the tomb, and placed in a box of canes, which is deposited in the temple. They usually weep and lament for their dead three days; but for those who are killed in war, they make a much longer and more grievous lamentation. 
Among the Natchez the death of any of their Suns, as I have before observed, is a most fatal event; for it is sure to be attended with the destruction of a great number of people of both sexes. Early in the spring 1725, the Stung Serpent, who was the brother of the Great Sun, and my intimate friend, was seized with a mortal distemper, which filled the whole nation of the Natchez with the greatest consternation and terror; for the two brothers had mutually engaged to follow each other to the land of spirits; and if the Great Sun should kill himself for the sake of his brother, very many people would likewise be put to death. When the Stung Serpent was despaired of, the chief of the guardians of the temple came to me in the greatest confusion, and acquainting me with the mutual engagements of the two brothers, begged of me to interest myself in preserving the Great Sun, and consequently a great part of the nation. $\mathrm{He}$ made the same request to the commander of the fort. Accordingly we were no sooner informed of the death of the Stung Serpent, than the commander, some of the principal Frenchmen, and I, went in a body to the hut of the Great Sun. We found him in despair; but, after some time, he seemed to be influenced by the arguments I used to dissuade him from putting himself to death. The death of the Stung Serpent was published by the firing of two muskets, which were answered by the other villages, and immediately cries and lamentations were heard on all sides. The Great Sun, in the mean time, remained inconsolable, and sat bent forwards, with his eyes towards the ground. In the evening, while we were still in his hut, he made a sign to his favourite wife; who in consequence of that threw a pailful of water on the fire, and extinguished it. This was a signal for extinguishing all the fires of the nation, and filled every one with terrible alarms, as it denoted that the Great Sun was still resolved to put himself to death. I gently chided him for altering his former resolution, but he assured me he had not, and desired us to go and sleep securely. We accordingly left him, pretending to rely on the assurance he had given us; but we took up our lodging in the hut of his chief servants, and stationed a soldier at the door of his hut, whom we ordered to give us notice of whatever happened. There was no need to fear our being betrayed by the wife of 
the Great Sun, or any others about him; for none of them had the least inclination to die, if they could help it. On the contrary, they all expressed the greatest thankfulness and gratitude to us for our endeavors to avert the threatened calamity from their nation.

Before we went to our lodgings we entered the hut of the deceased, and found him on his bed of state, dressed in his finest cloaths, his face painted with vermilion, shod as if for a journey, with his feather-crown on his head. To his bed were fastened his arms, which consisted of a double-barreled gun, a pistol, a bow, a quiver full of arrows, and a tomahawk. Round his bed were placed all the calumets of peace he had received during his life, and on a pole, planted in the ground near it, hung a chain of forty-six rings of cane painted red, to express the number of enemies he had slain. All his domesticks were round him, and they presented victuals to him at the usual hours, as if he were alive. The company in his hut were composed of his favourite wife, of a second wife, which he kept in another village, and visited when his favourite was with child; of his chancellor, his physician, his chief domestic, his pipe-bearer, and some old women, who were all to be strangled at his interment. To these victims a noble woman voluntarily joined herself, resolving, from her friendship to the Stung Serpent, to go and live with him in the country of spirits. I regretted her on many accounts, but particularly as she was intimately acquainted with the virtues of simples, had by her skill saved many of our people's lives, and given me many useful instructions. After we had satisfied our curiosity in the hut of the deceased, we retired to our hut, where we spent the night. But at day-break we were suddenly awaked, and told that it was with difficulty the Great Sun was kept from killing himself. We hastened to his hut, and upon entering it I remarked dismay and terror painted upon the countenances of all who were present. The Great Sun held his gun by the butt-end, and seemed enraged that the other Suns had seized upon it, to prevent him from executing his purpose. I addressed myself to him, and after opening the pan of the lock, to let the priming fall out, I chided him gently for his not acting according to his former resolution. He pretended at first 
not to see me; but, after some time, he let go his hold of the musket, and shook hands with me without speaking a word. I then went towards his wife, who all this while had appeared in the utmost agony and terror, and I asked her if she was ill. She answered me, "Yes, very ill," and added, "if you leave us, my husband is a dead man, and all the Natchez will die; stay then, for he opens his ears only to your words, which have the sharpness and strength of arrows. You are his true friend, and do not laugh when you speak, like most of the Frenchmen." The Great Sun at length consented to order his fire to be again lighted, which was the signal for lighting the other fires of the nation, and dispelled all their apprehensions.

Soon after the natives begun the dance of death, and prepared for the funeral of the Stung Serpent. Orders were given to put none to death on that occasion, but those who were in the hut of the deceased. A child however had been strangled already by its father and mother, which ransomed their lives upon the death of the Great Sun, and raised them from the rank of Stinkards to that of Nobles. Those who were appointed to die were conducted twice a day, and placed in two rows before the temple, where they acted over the scene of their death, each accompanied by eight of their own relations who were to be their executioners, and by that office exempted themselves from dying upon the death of any of the Suns, and likewise raised themselves to the dignity of men of rank.

Mean while thirty warriors brought in a prisoner, who had formerly been married to a female Sun; but, upon her death, instead of submitting to die with her, had fled to New Orleans, and offered to become the hunter and slave of our commander in chief. The commander accepting his offer, and granting him his protection, he often visited his countrymen, who, out of complaisance to the commander, never offered to apprehend him: but that officer being now returned to France, and the runaway appearing in the neighbourhood, he was now apprehended, and numbered among the other victims. Finding himself thus unexpectedly trapped, he began to cry bitterly; but three old women, who were his relations, offering to die in his stead, he was not only again exempted from death, but 


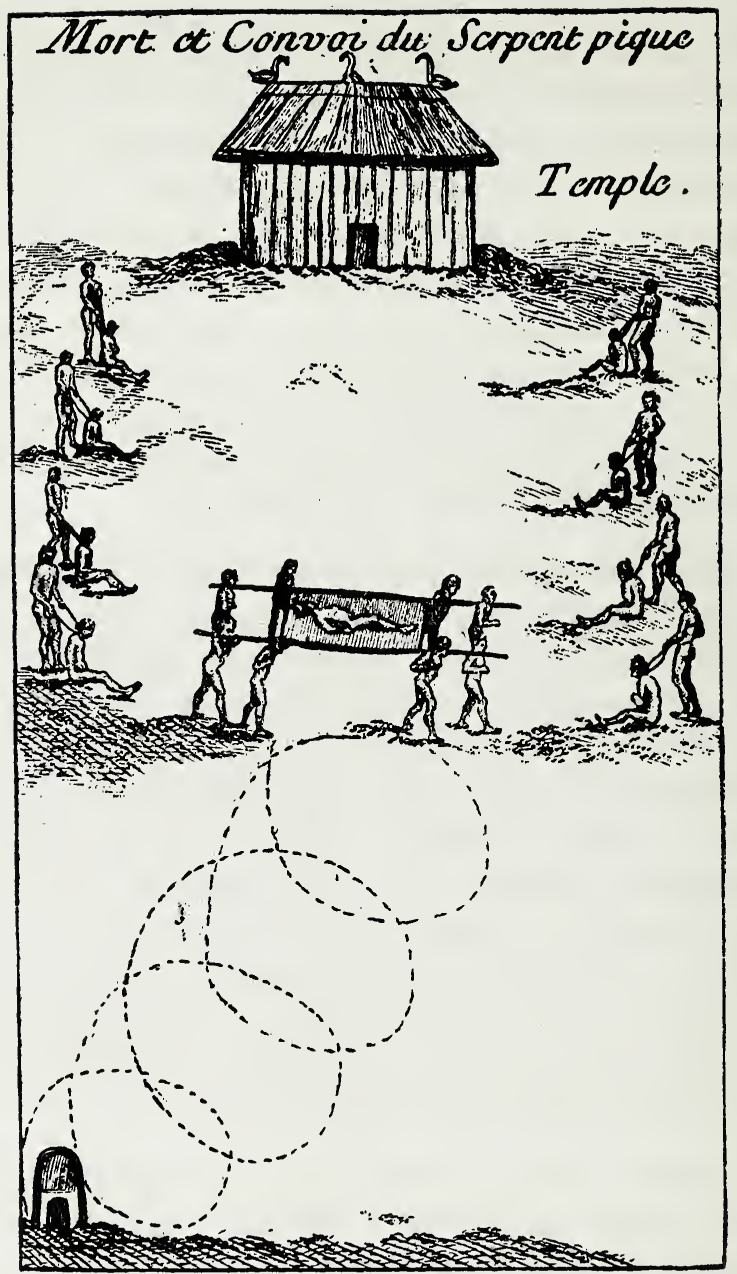

Burial of the Stung Serpent

raised to the dignity of a man of rank. Upon this he afterwards became insolent, and profiting by what he had seen and learned at New Orleans, he easily, on many occasions, made his fellow-countrymen his dupes.

On the day of the interment, the wife of the deceased made a very moving speech to the French who were present, recommending her children, to whom she also addressed herself, to their friendship, and advising perpetual union between 
the two nations. Soon after the master of the ceremonies appeared in a red-feathered crown, which half encircled his head, having a red staff in his hand in the form of a cross, at the end of which hung a garland of black feathers. All the upper part of his body was painted red, excepting his arms, and from his girdle to his knees hung a fringe of feathers, the rows of which were alternately white and red. When he came before the hut of the deceased, he saluted him with a great hoo, and then began the cry of death, in which he was followed by the whole people. Immediately after the Stung Serpent was brought out on his bed of state, and was placed on a litter, which six of the guardians of the temple bore on their shoulders. The procession then began, the master of the ceremonies walking first, and after him the oldest warrior, holding in one hand the pole with the rings of canes, and in the other the pipe of war, a mark of the dignity of the deceased. Next followed the corpse, after which came those who were to die at the interment. The whole procession went three times round the hut of the deceased, and then those who carried the corpse proceeded in a circular kind of march, every turn intersecting the former, until they came to the temple. At every turn the dead child was thrown by its parents before the bearers of the corpse, that they might walk over it; and when the corpse was placed in the temple the victims were immediately strangled. The Stung Serpent and his two wives were buried in the same grave within the temple; the other victims were interred in different parts, and after the ceremony they burnt, according to custom, the hut of the deceased. 


\section{SECTION V. \\ Of the Arts and Manufactures of the Natives.}

THE arts and manufactures of the natives are so insignifi-

cant, when compared with ours, that I should not have thought of treating of them, if some persons of distinction had not desired me to say something of them, in order to shew the industry of those people, and how far invention could carry them, in supplying those wants which human nature is continually exposed to.

As they would have frequent occasion for fire, the manner of lighting it at pleasure must have been one of the first things that they invented. Not having those means which we use, they bethought themselves of another ingenious method which they generally practise. They take a dry dead stick from a tree, about the thickness of their finger, and pressing one end against another dry piece of wood, they turn it round as swiftly as they can till they see the smoke appear, then blowing gently soon make the wood flame.

Cutting instruments are almost continually wanted; but as they had no iron, which, of all metals, is the most useful in human society, they were obliged, with infinite pains, to form hatchets out of large flints, by sharpening their thin edge, and making a hole through them for receiving the handle. To cut down trees with these axes would have been almost an impracticable work; they were therefore obliged to light fires round the roots of them, and to cut away the charcoal as the fire eat into the tree. They supplied the want of knives for cutting their victuals with thin splits of a hard cane, which they could easily renew as they wore out.

They made their bows of acacia wood, which is hard and easily cleft; and at first their bowstrings were made of the bark of the wood, but now they make them of the thongs of hides. Their arrows are made of a shrub that sends out long straight shoots; but they make some of small hard reeds: those that are intended for war, or against the buffalo, the deer, or large carp, are pointed with the sharp scale of the armed fish, which is neatly fastened to the head of the arrow with splits of cane and fish-glue. 
The skins of the beasts which they killed in hunting naturally presented themselves for their covering; but they must be dressed however before they could be properly used. After much practice they at length discovered that the brain of any animal suffices to dress its skin. To sew those skins they use the tendons of animals beat and split into threads, and to pierce the skins they apply the bone of a heron's leg, sharpened like an awl.

To defend themselves against the inclemencies of the weather, they built huts of wood, which were close and strong enough to resist the impetuosity of the wind. These huts are each a perfect square; none of them are less than fifteen feet square, and some of them are more than thirty feet in each of their fronts. They erect these huts in the following manner: they bring from the woods several young walnut-trees, about four inches in diameter, and thirteen or twenty feet high; they plant the strongest of these in the four corners, and the others fifteen inches from each other in straight lines, for the sides of the building; a pole is then laid horizontally along the sides in the inside, and all the poles are strongly fastened to it by split canes. Then the four corner poles are bent inwards till they all meet in the centre, where they are strongly fastened together; the side-poles are then bent in the same direction, and bound down to the others; after which they make a mortar of mud mixed with Spanish beard, with which they fill up all the chinks, leaving no opening but the door, and the mud they cover both outside and inside with mats made of the splits of cane. The roof is thatched with turf and straw intermixed, and over all is laid a mat of canes, which is fastened to the tops of the walls by the creeping plant. These huts will last twenty years without any repairs.

The natives having once built for themselves fixed habitations, would next apply themselves to the cultivation of the ground. Accordingly, near all their habitations, they have fields of maiz, and of another nourishing grain called Choupichoul, which grows without culture. For dressing their fields they invented hoes, which are formed in the shape of an $\mathrm{L}$, having the lower part flat and sharp; and to take the husk 
from their corn they made large wooden mortars, by hollowing the trunks of trees with fire.

To prepare their maiz for food, and likewise their venison and game, there was a necessity for dressing them over the fire, and for this purpose they bethought themselves of earthen ware, which is made by the women, who not only form the vessel, but dig up and mix the clay. In this they are tolerable artists; they make kettles of an extraordinary size, pitchers with a small opening, gallon bottles with long necks, pots or pitchers for their bear oil, which will hold forty pints; lastly, large and small plates in the French fashion: I had some made out of curiosity upon the model of my delf-ware, which were a very pretty red. For sifting the flour of their maiz, and for other uses, the natives make sieves of various finenesses of the splits of cane. To supply themselves with fish they make nets of the bark of the limetree; but the large fish they shoot with arrows.

The beds of the natives are placed round the sides of their huts, about a foot and a half from the ground, and are formed in this manner. Six forked stakes support two poles, which are crossed by three others, over which canes are laid so close as to form an even surface, and upon these are laid several bear skins, which serve for the bed furniture; a buffalo's skin is the coverlet, and a sack stuft with Spanish beard is the bolster. The women sometimes add to this furniture of the bed mats wove of canes, dyed of three colours, which colours in the weaving are formed into various figures. These mats render the bottom of the bed still smoother, and in hot weather they remove the bear skins and lie upon them. Their seats or stools, which they seldom use, are about six or seven inches high, and the seat and feet are made of the same piece.

The women likewise make a kind of hampers to carry corn, flesh, fish, or any other thing which they want to transport from one place to another; they are round, deeper than broad, and of all sizes. Here, as well as in other countries, the women take special care to lay up securely all their trinkets and finery. They make baskets with long lids that roll doubly over them, and in these they place their ear-rings and pendants, their 
bracelets, garters, their ribbands for their hair, and their vermilion for painting themselves, if they have any, but when they have no vermilion they boil ochre, and paint themselves with that.

The women also make the men's girdles and garters, and the collars for carrying their burdens. These collars are formed of two belts of the breadth of the hand of bear's skin, dressed so as to soften it, and these belts are joined together by long cross straps of the same leather, that serve to tie the bundles, which are oftener carried by the women than the men. One of the broad belts goes over their shoulders, and the other across their forehead, so that those two parts mutually ease each other.

The women also make several works in embroidery with the skin of the porcupine, which is black and white, and is cut by them into thin threads, which they dye of different colours. Their designs greatly resemble those which we meet with on gothic architecture; they are formed of straight lines, which when they meet always cross each other, or turn off at square angles.

The conveniences for passing rivers would soon be suggested to them by the floating of wood upon the water. Accordingly one of their methods of crossing rivers is upon floats of canes, which are called by them Cajeu, and are formed in this manner: They cut a great number of canes, which they tie up into faggots, part of which they fasten together sideways, and over these they lay a row crossways, binding all close together, and then launching it into the water. For carrying a great number of men with their necessary baggage, they soon found it necessary to have other conveniences; and nothing appeared so proper for this as some of their large trees hollowed; of these they accordingly made their pettyaugres, which as I mentioned above are sometimes so large as to carry ten or twelve ton weight. These pettyaugres are conducted by short oars, called Pagaies, about six feet long, with broad points, which are not fastened to the vessel, but managed by the rowers like shovels. 


\section{SECTION VI. \\ Of the Attire and Diversions of the Natives: Of their Meals and Fastings.}

THE natives of Louisiana, both men and women, wear a very thin dress in the summer. During the heat the men wear only a little apron of deer skin, dressed white or dyed black; but hardly any but chiefs wear black aprons. Those who live in the neighbourhood of the French settlements wear aprons of coarse limbourgs, a quarter of a yard broad, and the whole breadth of the cloth, or five quarters long; these aprons are fastened by a girdle about their waists, and tucked up between the thighs.

During the heats the women wear only half a yard of limbourg stuff about their middle, which covers them down to the knees; or in place of that they use deer skin; and the rest of the body both in men and women is naked.

Many of the women wear cloaks of the bark of the mulberry-tree, or of the feathers of swans, turkies, or India ducks. The bark they take from young mulberry shoots that rise from the roots of trees that have been cut down; after it is dried in the sun they beat it to make all the woody part fall off, and they give the threads that remain a second beating, after which they bleach them by exposing them to the dew. When they are well whitened they spin them about the coarseness of packthread, and weave them in the following manner: they plant two stakes in the ground about a yard and a half asunder, and having stretched a cord from the one to the other, they fasten their threads of bark double to this cord, and then interweave them in a curious manner into a cloak of about a yard square with a wrought border round the edges.

The young boys and girls go quite naked; but the girl at the age of eight or ten put on a little petticoat, which is a kind of fringe made of threads of mulberry bark. The boys do not wear any covering till they are twelve or thirteen years of age.

Some women even in hot weather have a small cloak wrapt round like a waistcoat; but when the cold sets in, they wear a 
second, the middle of which passes under the right arm, and the two ends are fastened over the left shoulder, so that the two arms are at liberty, and one of the breasts is covered. They wear nothing on their heads; their hair is suffered to grow to its full length, except in the fore-part, and it is tied in a cue behind in a kind of net made of mulberry threads. They carefully pick out all the hairs that grow upon any part of their body.

The shoes of the men and women are of the same fashion, but they rarely wear any but when they travel. They are made of deer-skin, the sole and upper-leather of the same piece, which is sewed together on the upper part of the foot; they are cut about three inches longer than the foot, and are folded over the toes; the quarters are about nine inches high, and fasten round the leg like a buskin. The womens ear-rings are made of the center part of a large shell, called burgo, which is about the thickness of one's little finger, and there is a hole in the ear about that size for holding it. Their necklaces are composed of several strings of longish or roundish kernelstones, somewhat resembling porcelaine; and with the smallest of these kernel-stones they ornament their furs, garters, \&c.

From their early youth the women get a streak pricked cross their nose; some of them have a streak pricked down the middle of their chin; others in different parts, especially the women of the nations who have the $\mathrm{R}$ in their language. I have seen some who were pricked all over the upper part of the body, not even excepting the breasts which are extremely sensible.

In the cold weather the men cover themselves with a shirt made of two dressed deer-skins, which is more like a fur nightgown than a shirt: they likewise, at the same time, wear a kind of breeches, which cover both the thighs and the legs. If the weather be very severe, they throw over all a buffalo's skin, which is dressed with the wool on, and this they keep next to their body to increase the warmth. In the countries where they hunt beavers, they make robes of six skins of those animals sewed together. 
The youths here are as much taken up about dress, and as fond of vying with each other in finery as in other countries; they paint themselves with vermilion very often; they deck themselves with bracelets made of the ribs of deer, which are bent by the means of boiling water, and when polished, look as fine as ivory; they wear necklaces like the women, and sometimes have a fan in their hand; they clip off the hair from the crown of the head, and there place a piece of swan's skin: with the down on; to a few hairs that they leave on that part they fasten the finest white feathers that they can meet with; a part of their hair which is suffered to grow long, they weave into a cue, which hangs over their left ear.

They likewise have their nose pricked, but no other part till they are warriors, and have performed some brave action, such as killing an enemy, and bringing off his scalp. Those who have signalized themselves by some gallant exploit, cause a tomahawk to be pricked on their left shoulder, underneath which is also pricked the hieroglyphic sign of the conquered nation. Whatever figure they intend to prick, is first traced on the skin with a bit of charcoal, and having fixed six needles in a piece of wood in two rows, in such a manner that they only stick out about the tenth part of an inch, they prick the skin all over the mark, and then rub charcoal dust over the part, which enters the punctures, and leaves a mark that can never be effaced. This pricking generally gives a fit of sickness to the patient, who is obliged for some time to live only on boiled maiz. The warriors also pierce the lower part of their ears, and make a hole an inch diameter, which they fill with iron wire. Besides these ear-rings they have a belt hung round with little bells, if they can purchase any from the French, so that they march more like mules than men. When they can get no bells, they fasten to their belts wild gourds with two or three pebbles in each. The chief ornament of the sovereigns, is their crown of feathers; this crown is composed of a black bonnet of net work, which is fastened to a red diadem about two inches broad. The diadem is embroidered with white kernel-stones, and surmounted with white feathers, which in the fore-part are about eight inches long, and half as much behind. This crown or feather hat makes a very pleasing appearance. 
All nations are not equally ingenious at inventing feasts, shews, and diversions, for employing the people agreeably, and filling up the void of their usual employments. The natives of Louisiana have invented but a very few diversions, and these perhaps serve their turn as well as a greater variety would do. The warriors practise a diversion which is called the game of the pole, at which only two play together at a time. Each has a pole about eight feet long, resembling a Roman $f$, and the game consists in rolling a flat round stone, about three inches diameter and an inch thick, with the edge somewhat sloping, and throwing the pole at the same time in such a manner, that when the stone rests, the pole may touch it or be near it. Both antagonists throw their poles at the same time, and he whose pole is nearest the stone counts one, and has the right of rolling the stone. The men fatigue themselves much at this game, as they run after their poles at every throw; and some of them are so bewitched by it, that they game away one piece of furniture after another. These gamesters however are very rare, and are greatly discountenanced by the rest of the people.

The women play with small bits of cane, about eight or nine inches long. Three of these they hold loosely in one hand, and knock them to the ground with another; if two of them fall with the round side undermost, she that played counts one; but if only one, she counts nothing. They are ashamed to be seen or found playing; and as far as I could discover, they never played for any stake.

The young people, especially the girls, have hardly any kind of diversion but that of the ball: this consists in tossing a ball from one to the other with the palm of the hand, which they perform with a tolerable address.

When the natives meet with a Frenchman whom they know, they shake hands with him, incline their head a little, and say in their own language, "Are you there, my friend?" If he has no serious affair to propose to them, or if they themselves have nothing of consequence to say, they pursue their journey.

If they happen to be going the same way with a French man, they never go before him, unless something of conse- 
quence oblige them. When you enter into their hut, they welcome you with the word of salutation, which signifies "Are you there, my friend?" then shake hands with you, and pointing to a bed, desire you to sit down. A silence of a few minutes then ensues till the stranger begins to speak, when he is offered some victuals, and desired to eat. You must taste of what they offer you, otherwise they will imagine that you despise them.

When the natives converse together, however numerous the assembly be, never more than one person speaks at once. If one of the company has any thing to say to another, he speaks so low that none of the rest hear him. Nobody is interrupted, even with the chiding of a child; and if the child be stubborn, it is removed elsewhere. In the council, when a point is deliberated upon and debated, they keep silence for a short time, and then they speak in their turns, no one offering to interrupt another.

The natives being habituated to their own prudent custom, it is with the utmost difficulty they can keep from laughing, when they see several French men or French women together, and always several of them speaking at the same time. I had observed them for two years stifling a laugh on those occasions, and had often asked the reason of it, without receiving any satisfactory answer. At length I pressed one of them so earnestly to satisfy me, that after some excuses, he told me in their language, "Our people say, that when several Frenchmen are together, they speak all at once, like a flock of geese."

All the nations whom I have known, and who inhabit from the sea as far as the Illinois, and even farther, which is a space of about fifteen hundred miles, carefully cultivate the maiz corn, which they make their principal subsistence. They make bread of it baked in cakes, another kind baked among the ashes, and another kind in water; they make of it also cold meal, roasted meal, gruel, which in this country is called Sagamity. This and the cold meal in my opinion are the two best dishes that are made of it; the others are only for a change. They eat the Sagamity as we eat soup, with a spoon made of a buffalo's horn. When they eat flesh or fish they use bread. They likewise use two kinds of millet, which they shell in the manner 
of rice; one of these is called Choupichoul, and the other Widlogouil, and they both grow almost without any cultivation.

In a scarcity of these kinds of corn, they have recourse to earth-nuts, which they find in the woods; but they never use these or chestnuts but when necessity obliges them.

The flesh-meats they usually eat are the buffalo, the deer, the bear, and the dog: they eat of all kind of water-fowl and fish; but they have no other way of dressing their meat but by roasting or boiling. The following is their manner of roasting their meat when they are in the fields hunting: they plant a stake in the ground sloping towards the fire, and on the point of this stake they spit their meat, which they turn from time to time. To preserve what they do not use, they cut it into thin pieces, which they dry, or rather half-roast, upon a grate made of canes placed cross-ways. They never eat raw flesh, as so many people have falsely imagined, and they limit themselves to no set hours for their meals, but eat whenever they are hungry; so that we seldom see several of them eating at once, unless at their feasts, when they all eat off the same plate, except the women, the boys, and the young girls, who have each a plate to themselves.

When the natives are sick, they neither eat flesh nor fish, but take Sagamity boiled in the broth of meat. When a man falls sick, his wife sleeps with the woman in the next bed to him, and the husband of that woman goes elsewhere. The natives, when they eat with Frenchmen, taste of nothing but of pure roast and boiled: they eat no sallad, and nothing raw but fruit. Their drink is pure water or pure brandy, but they dislike wine and all made liquors.

Having mentioned their manner of feeding, I shall say a word or two of their manner of fasting. When they want rain, or when they desire hot weather for ripening their corn, they address themselves to the old man who has the greatest character for living wisely, and they intreat him to invoke the aerial spirits, in order to obtain what they demand. This old man, who never refuses his countrymen's request, prepares to fast for nine days together. He orders his wife to withdraw, and 
during the whole time he eats nothing but a dish of gruel boiled in water, without salt, which is brought him once a day by his wife after sun-set. They never will accept of any reward for this service, that the spirits may not be angry with them.

\section{SECTION VII. \\ Of the Indian Art of War.}

I Will now present the reader with their manner of making war, which is uniformly the same among all the nations. When one nation intends to make war upon another in all the forms, they hold a council of war, which is composed of the oldest and bravest warriors. It is to be supposed that this nation has been insulted, that the other has committed some hostilities against it, or that they have disturbed them in their hunting country, coming thither to steal their game, as they call it. There is always some pretence for declaring war; and this pretence, whether true or false, is explained by the warchief, who omits no circumstance that may excite his nation to take up arms.

After he has explained the reasons for the war, the old men debate the question in presence of the great chief or sovereign of the nation. This sovereign and the great chief of war are only witnesses of the debate; for the opinion of the old men always prevails, and the two chiefs voluntarily agree to it, from their respect and their great regard for the experience and wisdom of those venerable counsellors.

If it is resolved to demand from the other nation the reason of the hostilities committed by them, they name one of their bravest and most eloquent warriors, as a second to their speech-maker or chancellor, who is to carry the pipe of peace, and address that nation. These two are accompanied by a troop of the bravest warriors, so that the embassy has the appearance of a warlike expedition; and, if satisfaction is not given, sometimes ends in one. The ambassadors carry no presents with them, to shew that they do not intend to supplicate or beg a peace: they take with them only the pipe of peace, 


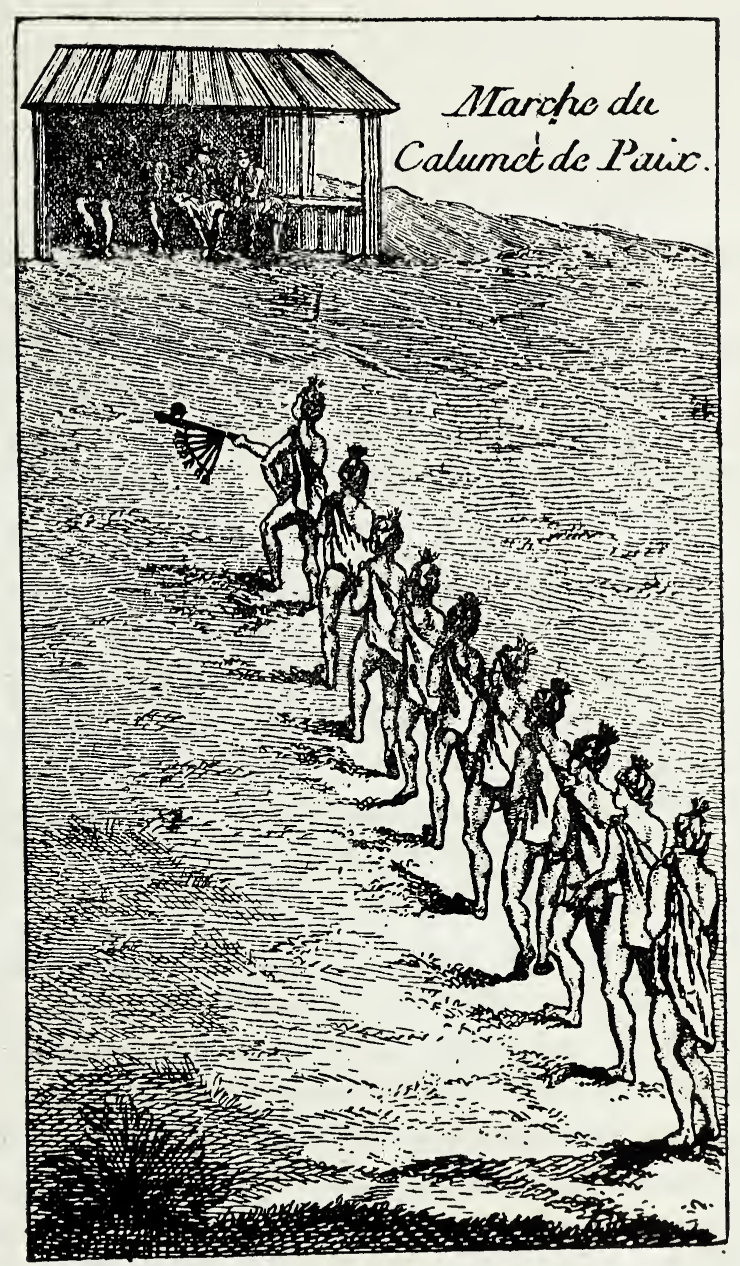

Bringing the Pipe of Peace

as a proof that they come as friends. The embassy is always well received, entertained in the best manner, and kept as long as possible; and if the other nation is not inclined to begin a war, they make very large presents to the ambassadors, and all their retinue, to make up for the losses which their nation complains of.

If a nation begins actual hostilities without any formalities, the nation invaded is generally assisted by several allies, 
keeps itself on the defensive, gives orders to those who live at a great distance to join the main body of the nation, prepares logs for building a fort, and every morning sends some warriors out upon the scout, choosing for that purpose those who trust more to their heels than their heart.

The assistance of the allies is generally solicited by the pipe of peace, the stalk of which is about four feet and a half long, and is covered all over with the skin of a duck's neck, the feathers of which are glossy and of various colours. To this pipe is fastened a fan made of the feathers of white eagles, the ends of which are black, and are ornamented with a tuft dyed a beautiful red.

When the allies are assembled a general council is held in presence of the sovereign, and is composed of the great warchief, the war-chiefs of the allies, and all the old warriors. The great war-chief opens the assembly with a speech, in which he exhorts them to take vengeance of the insults they have received; and after the point is debated, and the war agreed upon, all the warriors go a hunting to procure game for the war-feast, which, as well as the war-dance, lasts three days.

The natives distinguish the warriors into three classes, namely, true warriors, who have always given proofs of their courage; common warriors, and apprentice-warriors. They likewise divide our military men into the two classes of true warriors and young warriors. By the former they mean the settlers, of whom the greatest part, upon their arrival, were soldiers, who being now perfectly acquainted with the tricks and wiles of the natives, practice them upon their enemy, whom they do not greatly fear. The young warriors are the soldiers of the regular troops, as the companies are generally composed of young men, who are ignorant of the stratagems used by the natives in time of war.

When the war-feast is ready the warriors repair to it, painted from head to foot with stripes of different colours. They have nothing on but their belt, from whence hangs their apron, their bells, or their rattling gourds, and their tomahawk. In their right hand they have a bow, and those of the 
north in their left carry a buckler formed of two round pieces of buffalo's hide sewed together.

The feast is kept in a meadow, the grass of which is mowed to a great extent; there the dishes, which are of hollow wood, are placed round in circles of about twelve or fifteen feet diameter, and the number of those circular tables is proportioned to the largeness of the assembly, in the midst of whom is placed the pipe of war upon the end of a pole seven or eight feet high. At the foot of this pole, in the middle of a circle, is placed the chief dish of all, which is a large dog roasted whole; the other plates are ranged circularly by threes; one of these contains maiz boiled in broth like gruel, another roasted deer's flesh, and the other boiled. They all begin with eating of the dog, to denote their fidelity and attachment to their chief; but before they taste of any thing, an old warrior, who, on account of his great age, is not able to accompany the rest to the war, makes an harangue to the warriors, and by recounting his own exploits, excites them to act with bravery against the enemy. All the warriors then, according to their rank, smoke in the pipe of war, after which they begin their repast; but while they eat, they keep walking continually, to signify that a warrior ought to be always in action and upon his guard.

While they are thus employed, one of the young men goes behind a bush about two hundred paces off, and raises the cry of death. Instantly all the warriors seize their arms, and run to the place whence the cry comes; and when they are near it the young warrior shews himself again, raises the cry of death, and is answered by all the rest, who then return to the feast, and take up the victuals which in their hurry they had thrown upon the ground. The same alarm is given two other times, and the warriors each time act as at first. The war drink then goes round, which is a heady liquor drawn from the leaves of the Cassine after they have been a long while boiled. The feast being finished, they all assemble about fifty paces from a large post, which represents the enemy; and this each of them in his turn runs up to, and strikes with his tomahawk, recounting at the same time all his former brave exploits, and sometimes boasting of valorous deeds that he never performed. But 
they have the complaisance to each other to pardon this gasconading.

All of them having successively struck the post, they begin the dance of war with their arms in their hands; and this dance and the war-feast are celebrated for three days together, after which they set out for the war. The women some time before are employed in preparing victuals for their husbands, and the old men in engraving upon bark the hieroglyphic sign of the nation that attacks, and of their number of warriors.

Their manner of making war is to attack by surprize; accordingly, when they draw near to any of the enemy's villages, they march only in the night; and that they may not be discovered, raise up the grass over which they trod. One half of the warriors watch, while the other half sleep in the thickest and most unfrequented part of the wood.

If any of their scouts can discover a hut of the enemy detached from the rest, they all surround it about day-break, and some of the warriors entering, endeavor to knock the people on the head as they awake, or take some man prisoner. Having scalped the dead, they carry off the women and children prisoners, and place against a tree near the hut the hieroglyphic picture, before which they plant two arrows with their points crossing each other. Instantly they retreat into the woods, and make great turnings to conceal their route.

The women and children whom they take prisoners are made slaves. But if they take a man prisoner the joy is universal, and the glory of their nation is at its height. The warriors, when they draw near to their own villages after an expedition, raise the cry of war three times successively; and if they have a man prisoner with them, immediately go and look for three poles to torture him upon; which, however weary or hungry they be, must be provided before they take any refreshment. When they have provided those poles, and tied the prisoner to them, they may then go and take some victuals. The poles are about ten feet long; two of them are planted upright in the ground at a proper distance, and the other is cut through in the middle, and the two pieces are fastened cross- 


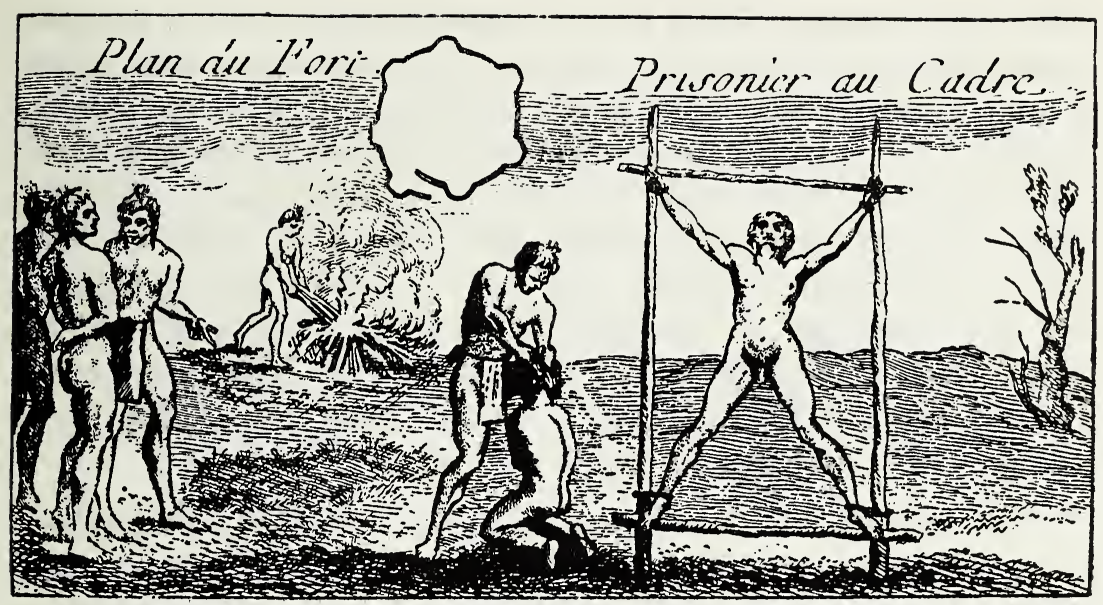

Torture of Prisoners-INSET: Plan of Fort

ways to the other two, so that they form a square about five feet every way. The prisoner being first scalped by the person who took him, is tied to this square, his hands to the upper part, and his feet to the lower, in such a manner that he forms the figure of a St. Andrew's cross. The young men in the mean time having prepared several bundles of canes, set fire to them; and several of the warriors taking those flaming canes, burn the prisoner in different parts of his body, while others burn him in other parts with their tobacco-pipes. The patience of prisoners in those miserable circumstances is altogether astonishing. No cries or lamentations proceed from them; and some have been known to suffer tortures, and sing for three days and nights without intermission. Sometimes it happens that a young woman who has lost her husband in the war, asks the prisoner to supply the room of the deceased, and her request is immediately granted.

I mentioned above that when one nation declares war against another, they leave a picture near one of their villages. That picture is designed in the following manner. On the top towards the right hand is the hieroglyphic sign of the nation that declares war; next is a naked man with a tomahawk in his hand; and then an arrow pointed against a woman, who is flying away, her hair floating behind her in the air; immediately 
before this woman is the proper emblem of the nation against whom the war is declared. All this is on one line; and below is drawn the figure of the moon, which is followed by one $I$, or more; and a man is here represented, before whom is a number of arrows which seem to pierce a woman who is running away. By this is denoted, when such a moon is so many days old, they will come in great numbers and attack such a nation; but this lower part of the picture does not always carry true intelligence. The nation that has offered the insult, or commenced hostilities wrongfully, rarely finds any allies even among those nations who call them brothers.

In carrying on a war they have no such thing as pitched battles, or carrying on of sieges; all the mischief they do each other, is by surprise and skirmishing, and in this their courage and address consists. Among them flight is no ways shameful; their bravery lies often in their legs; and to kill a man asleep or at unawares, is quite as honourable among them, as to gain a signal victory after a stout battle.

When a nation is too weak to defend itself in the field, they endeavour to protect themselves by a fort. This fort is built circularly of two rows of large logs of wood, the logs of the inner row being opposite to the joining of the logs of the outer row. These logs are about fifteen feet long, five feet of which are sunk in the ground. The outer logs are about two feet thick, and the inner about half as much. At every forty paces along the wall a circular tower jets out; and at the entrance of the fort, which is always next to the river, the two ends of the wall pass beyond each other, and leave a side opening. In the middle of the fort stands a tree with its branches lopt off within six or eight inches of the trunk, and this serves for a watch-tower. Round this tree are some huts, for the protection of the women and children from random arrows; but notwithstanding all these precautions for defense, if the besieged are but hindered from coming out to water, they are soon obliged to retire.

When a nation finds itself no longer able to oppose its enemy, the chiefs send a pipe of peace to a neutral nation, and solicit their mediation, which is generally successful, the van- 
quished nation sheltering themselves under the name of the mediators, and for the future making but one nation with them.

Here it may be observed that when they go to attack others, it sometimes happens that they lose some of their own warriors. In that case, they immediately, if possible, scalp their dead friends, to hinder the enemy from having that subject of triumph. Moreover, when they return home, whether as victors or otherwise, the great warchief pays to the respective families for those whom he does not bring back with him; which renders the chiefs very careful of the lives of their warriors.

\section{CHAPTER IV.}

Of the Negroes of Louisiana.

\section{SECTION I.}

Of the Choice of Negroes; of their Distemper, and the Manner of curing them.

HAVING finished my account of the natives of Louisiana, I shall conclude this treatise with some observations relating to the negroes; who, in the lower part of the province especially, perform all the labours of agriculture. On that account I have thought proper to give some instructions concerning them, for the benefit of those who are inclined to settle in that province.

The negroes must be governed differently from the Europeans; not because they are black, nor because they are slaves; but because they think differently from the white men.

First, they imbibe a prejudice from their infancy, that the white men buy them for no other purpose but to drink their blood; which is owing to this, that when the first negroes saw the Europeans drink claret, they imagined it was blood, as that wine is of a deep red colour; so that nothing but the actual experience of the contrary can eradicate the false opinion. But as none of those slaves who have had that experience ever return to their own country, the same prejudice continues to subsist on the coast of Guinea where we purchase them. Some 
who are strangers to the manner of thinking that prevails among the negroes, may perhaps think that the above remark is of no consequence, in respect to those slaves who are already sold to the French. There have been instances however of bad consequences flowing from this prejudice; especially if the negroes found no old slave of their own country upon their first arrival in our colonies. Some of them have killed or drowned themselves, several of them have deserted (which they call making themselves Marons) and all this from an apprehension that the white men were going to drink their blood. When they desert they believe they can get back to their own country by going round the sea, and may live in the woods upon the fruits, which they imagine are as common every where as with them.

They are very superstitious, and are much attached to their prejudices, and little toys which they call gris, gris. It would be improper therefore to take them from them, or even speak of them to them; for they would believe themselves undone, if they were stripped of those trinkets. The old negroes soon make them lose conceit of them.

The first thing you ought to do when you purchase negroes, is to cause them to be examined by a skilful surgeon and an honest man, to discover if they have the venereal or any other distemper. When they are viewed, both men and women are stripped naked as the hand, and are carefully examined from the crown of the head to the sole of the feet, then between the toes and between the fingers, in the mouth, in the ears, not excepting even the parts naturally concealed, though then exposed to view. You must ask your examining surgeon if he is acquainted with the distemper of the yaws, which is the virus of Guinea, and incurable by a great many French surgeons, though very skilful in the management of European distempers. Be careful not to be deceived in this point; for your surgeon may be deceived himself; therefore attend at the examination yourself, and observe carefully over all the body of the negro, whether you can discover any parts of the skin, which though black like the rest, are however as smooth as a looking-glass, without any tumor or rising. Such spots may be easily dis- 
covered; for the skin of a person who goes naked is usually all over wrinkles. Wherefore if you see such marks you must reject the negro, whether man or woman. There are always experienced surgeons at the sale of new negroes, who purchase them; and many of those surgeons have made fortunes by that means; but they generally keep their secret to themselves.

Another mortal distemper with which many negroes from Guinea are attacked, is the scurvy. It discovers itself by the gums, but sometimes it is so inveterate as to appear outwardly, in which case it is generally fatal. If any of my readers shall have the misfortune to have a negro attacked with one of those distempers, I will now teach him how to save him, by putting him in a way of being radically cured by the surgeons; for I have no inclination to fall out with those gentlemen. I learned this secret from a negro physician, who was upon the king's plantation, when I took the superintendence of it.

You must never put an iron instrument into the yaw; such an application would be certain death. In order to open the yaw, you take iron rust reduced to an impalpable powder, and passed through a fine search; you afterwards mix that powder with citron juice till it be of the consistence of an ointment, which you spread upon a linen cloth greased with hog's grease, or fresh lard without salt, for want of a better. You lay the plastier upon the yaw, and renew it evening and morning, which will open the yaw in a very short time without any incision.

The opening being once made, you take about the bulk of a goose's egg of hog's lard without salt, in which you incorporate about an ounce of good terebinthine; after which take a quantity of powdered verdigris, and soak it half a day in good vinegar, which you must then pour off gently with all the scum that floats at top. Drop a cloth all over with the verdigris that remains, and upon that apply your last ointment. All these operations are performed without the assistance of fire. The whole ointment being well mixed with a spatula, you dress the yaw with it; after that put your negro into a copious sweat, and he will be cured. Take special care that your surgeon uses no mercurial medicine, as I have seen; for that will occasion the death of the patient. 
The scurvy is no less to be dreaded than the yaws; nevertheless you may get the better of it, by adhering exactly to the following prescription: take some scurvy-grass, if you have any plants of it, some ground-ivy, called by some St. John's wort, water-cresses from a spring or brook, and for want, of that, wild cresses; take these three herbs, or the two last, if you have no scurvy-grass; pound them, and mix them with citron-juice, to make of them a soft paste, which the patient must keep upon both his gums till they be clean, at all times but when he is eating. In the mean while he must be suffered to drink nothing but an infusion of the herbs above named. You pound two handfuls of them, roots and all, after washing off any earth that may be upon the roots or leaves; to these you join a fresh citron, cut into slices. Having pounded all together, you then steep them in an earthen pan in a pint of pure water of the measure of Paris; after that you add about the size of a walnut of powdered and purified saltpetre, and to make it a little relishing to the negro, you add some powder sugar. After the water has stood one night, you squeeze out the herbs pretty strongly. The whole is performed cold, or without fire. Such is the dose for a bottle of water Paris measure; but as the patient ought to drink two pints a day, you may make several pints at a time in the above proportion.

In these two distempers the patients must be supported with good nourishment, and made to sweat copiously. It would be a mistake to think that they ought to be kept to a spare diet; you must give them nourishing food, but a little at a time. A negro can no more than any other person support remedies upon bad food, and still less upon a spare diet; but the quantity must be proportioned to the state of the patient, and the nature of the distemper. Besides, good food makes the best part of the remedy to those who in common are but poorly fed. The negro who taught me these two remedies, observing the great care I took of both the negro men and negro women, taught me likewise the cure of all the distempers to which the women are subject; for the negro women are as liable to diseases as the white women. 


\section{SECTION II.}

Of the Manner of governing the Negroes.

WHEN a negro man or woman comes home to you, it is proper to caress them, to give them something good to eat, with a glass of brandy; it is best to dress them the same day, to give them something to sleep on, and a covering. I suppose the others have been treated in the same manner; for those marks of humanity flatter them, and attach them to their masters. If they are fatigued or weakened by a journey, or by any distempers, make them work little; but keep them always busy as long as they are able to do any thing, never suffering them to be idle, but when they are at their meals. Take care of them when they are sick, and give attention both to their remedies and their food, which last ought then to be more nourishing than what they usually subsist upon. It is your interest so to do, both for their preservation, and to attach them more closely to you; for though many Frenchmen say that negroes are ungrateful, I have experienced that it is very easy to render them much attached to you by good treatment, and by doing them justice, as I shall mention afterwards.

If a negro woman lies-in, cause her to be taken care of in every thing that her condition makes necessary, and let your wife, if you have one, not disdain to take the immediate care of her herself, or at least have an eye over her.

A Christian ought to take care that the children be baptised and instructed, since they have an immortal soul. The mother ought then to receive half a ration more than usual, and a quart of milk a day, to assist her to nurse her child.

Prudence requires that your negroes be lodged at a proper distance, to prevent them from being troublesome or offensive; but at the same time near enough for your conveniently observing what passes among them. When I say that they ought not to be placed so near your habitation as to be offensive, I mean by that the smell which is natural to some nations of negroes, such as the Congos, the Angolas, the Aradas, and others. On this account it is proper to have in their camp a bathing place formed by thick planks, buried in the earth about a foot or a 
foot and a half at most, and never more water in it than about that depth, for fear lest the children should drown themselves in it; it ought likewise to have an edge, that the little children may not have access to it, and there ought to be a pond without the camp to supply it with water and keep fish. The negro camp ought to be inclosed all round with palisades, and to have a door to shut with a lock and key. The huts ought to be detached from each other, for fear of fire, and to be built in direct lines, both for the sake of neatness, and in order to know easily the hut of each negro. But that you may be as little incommoded as possible with their natural smell, you must have the precaution to place the negro camp to the north or north-east of your house, as the winds that blow from these quarters are not so warm as the others, and it is only when the negroes are warm that they send forth a disagreeable smell.

The negroes that have the worst smell are those that are the least black; and what I have said of their bad smell, ought to warn you to keep always on the windward side of them when you visit them at their work; never to suffer them to come near your children, who, exclusive of the bad smell, can learn nothing good from them, either as to morals, education, or language.

From what I have said, I conclude that a French father and his wife are great enemies to their posterity when they give their children such nurses. For the milk being the purest blood of the woman, one must be a step-mother indeed to give her child to a negro nurse in such a country as Louisiana, where the mother has all conveniences of being served, of accommodating and carrying their children, who by that means may be always under their eyes. The mother then has nothing else to do but to give the breast to her child.

I have no inclination to employ my pen in censuring the over-delicacy and selfishness of the women, who thus sacrifice their children; it may, without further illustration, be easily perceived how much society is interested in this affair. I shall only say, that for any kind of service whatever about the house, I would advise no other kind of negroes, either young or old, but Senegals, called among themselves Diolaufs, because of all 
the negroes I have known, these have the purest blood; they have more fidelity and a better understanding than the rest, and are consequently fitter for learning.a trade, or for menial services. It is true they are not so strong as the others for the labours of the field, and for bearing the great heats.

The Senegals however are the blackest, and I never saw any who had a bad smell. They are very grateful; and when one knows how to attach them to him, they have been found to sacrifice their own life to save that of their master. They are good commanders over other negroes, both on account of their fidelity and gratitude, and because they seem to be born for commanding. As they are high-minded, they may be easily encouraged to learn a trade, or to serve in the house, by the distinction they will thereby acquire over the other negroes, and the neatness of dress which that condition will entitle them to.

When a settler wants to make a fortune, and manage his plantation with œconomy, he ought to prefer his interest to his pleasure, and only take the last by snatches. He ought to be the first up and the last a-bed, that he may have an eye over every thing that passes in his plantation. It is certainly his interest that his negroes labour a good deal: but it ought to be an equal and moderate labour, for violent and continual labours would soon exhaust and ruin them; whereas by keeping them always moderately employed, they neither exhaust their strength nor ruin their constitution. By this they are kept in good health, and labour longer, and with more good will: besides it must be allowed that the day is long enough for an assiduous labourer to deserve the repose of the evening.

To accustom them to labour in this manner I observed the following method: I took care to provide one piece of work for them before another was done, and I informed their commander or driver in their presence, that they might not lose time, some in coming to ask what they were to do, and others in waiting for an answer. Besides I went several times a day to view them, by roads which they did not expect, pretending to be going a hunting or coming from it. If I observed them idle, I reprimanded them, and if when they saw me coming, they wrought too hard, I told them that they fatigued them- 
selves, and that they could not continue at such hard labour during the whole day, without being harassed, which I did not want.

When I surprised them singing at their work, and perceived that they had discovered me, I said to them chearfully, Courage, my boys, I love to see you merry at your work; but do not sing so loud, that you may not fatigue yourselves, and at night you shall have a cup of Tafia (or rum) to give you strength and spirits. One cannot believe the effect such a discourse would have upon their spirits, which was easily discernible from the chearfulness upon their countenances, and their ardour at work.

If it be necessary not to pass over any essential fault in the negroes, it is no less necessary never to punish them but when they have deserved it, after a serious enquiry and examination supported by an absolute certainty, unless you happen to catch them in the fact. But when you are fully convinced of the crime, by no means pardon them upon any assurances or protestations of theirs, or upon the solicitations of others; but punish them in proportion to the fault they have done, yet always with humanity, that they may themselves be brought to confess that they have deserved the punishment they have received. A Christian is unworthy of that name when he punishes with cruelty, as is done to my knowledge in a certain colony, to such a degree that they entertain their guests with such spectacles, which have more of barbarity than humanity in them. When a negro comes from being whipped, cause the sore parts to be washed with vinegar mixed with salt, Jamaica pepper, which grows in the garden, and even a little gunpowder.

As we know from experience that most men of a low extraction, and without education, are subject to thieving in their necessities, it is not at all surprising to see negroes thieves, when they are in want of every thing, as I have seen many badly fed, badly cloathed, and having nothing to lie upon but the ground. I shall make but one reflection. If they are slaves, it is also true that they are men, and capable of becoming Christians: besides, it is your intention to draw advantage from them, is it not therefore reasonable to take all the care of 
them that you can? We see all those who understand the government of horses give an extraordinary attention to them, whether they be intended for the saddle or the draught. In the cold season they are well covered and kept in warm stables. In the summer they have a cloth thrown over them, to keep them from the dust, and at all times good litter to lie upon. Every morning their dung is carried away, and they are well curried and combed. If you ask those masters, why they bestow so much pains upon beasts? they will tell you, that, to make a horse serviceable to you, you must take a good deal of care of him, and that it is for the interest of the person to whom a horse belongs, so to do. After this example, can one hope for labour from negroes, who very often are in want of necessaries? Can one expect fidelity from a man, who is denied what he stands most in need of? When one sees a negro, who labours hard and with much assiduity, it is common to say to him, by way of encouragement, that they are well pleased with him, and that he is a good negro. But when any of them, who understand our language, are so complimented, they very properly reply, Masser, when negre be much fed, negre work much; when negre has good masser, negre be good.

If I advise the planters to take great care of their negroes, I at the same time shew them that their interest is connected in that with their humanity. But I do no less advise them always to distrust them, without seeming to fear them, because it is as dangerous to shew a concealed enemy that you fear him, as to do him an injury.

Therefore make it your constant custom to shut your doors securely, and not to suffer any negro to sleep in the house with you, and have it in their power to open your door. Visit your negroes from time to time, at night and on days and hours when they least expect you, in order to keep them always in fear of being found absent from their huts. Endeavour to assign each of them a wife, to keep clear of debauchery and its bad consequences. It is necessary that the negroes have wives, and you ought to know that nothing attaches them so much to a plantation as children. But above all do not suffer any of them to abandon his wife, when he has once made choice of one 
in your presence. Prohibit all fighting under pain of the lash, otherwise the women will often raise squabbles among the men.

Do not suffer your negroes to carry their children to the field with them, when they begin to walk, as they only spoil the plants and take off the mothers from their work. If you have a few negro children, it is better to employ an old negro woman to keep them in the camp, with whom the mothers may leave something for their children to eat. This you will find to be the most profitable way. Above all do not suffer the mothers ever to carry them to the edge of the water, where there is too much to be feared.

For the better subsistence of your negroes, you ought every week to give them a small quantity of salt and of herbs of your garden, to give a better relish to their Couscou, which is a dish made of the meal of rice or maiz soaked in broth.

If you have any old negro, or one in weak health, employ him in fishing both for yourself and your negroes. His labour will be well worth his subsistence.

It is moreover for your own interest to give your negroes a small piece of waste ground to improve at the end of your own, and to engage them to cultivate it for their own profit, that they may be able to dress a little better, by selling the produce of it, which you ought to buy from them upon fair and just terms. It were better that they should employ themselves in cultivating that field on Sundays, when they are not Christians, than do worse. In a word, nothing is more to be dreaded than to see the negroes assemble together on Sundays, since, under pretence of Calinda or the dance, they sometimes get together to the number of three or four hundred, and make a kind of Sabbath, which it is always prudent to avoid; for it is in those tumultuous meetings that they sell what they have stolen to one another, and commit many crimes. In these likewise they plot their rebellions.

To conclude, one may, by attention and humanity, easily manage negroes; and, as an inducement, one has the satisfaction to draw great advantage from their labours.

[THE END] 


\section{INDEX}







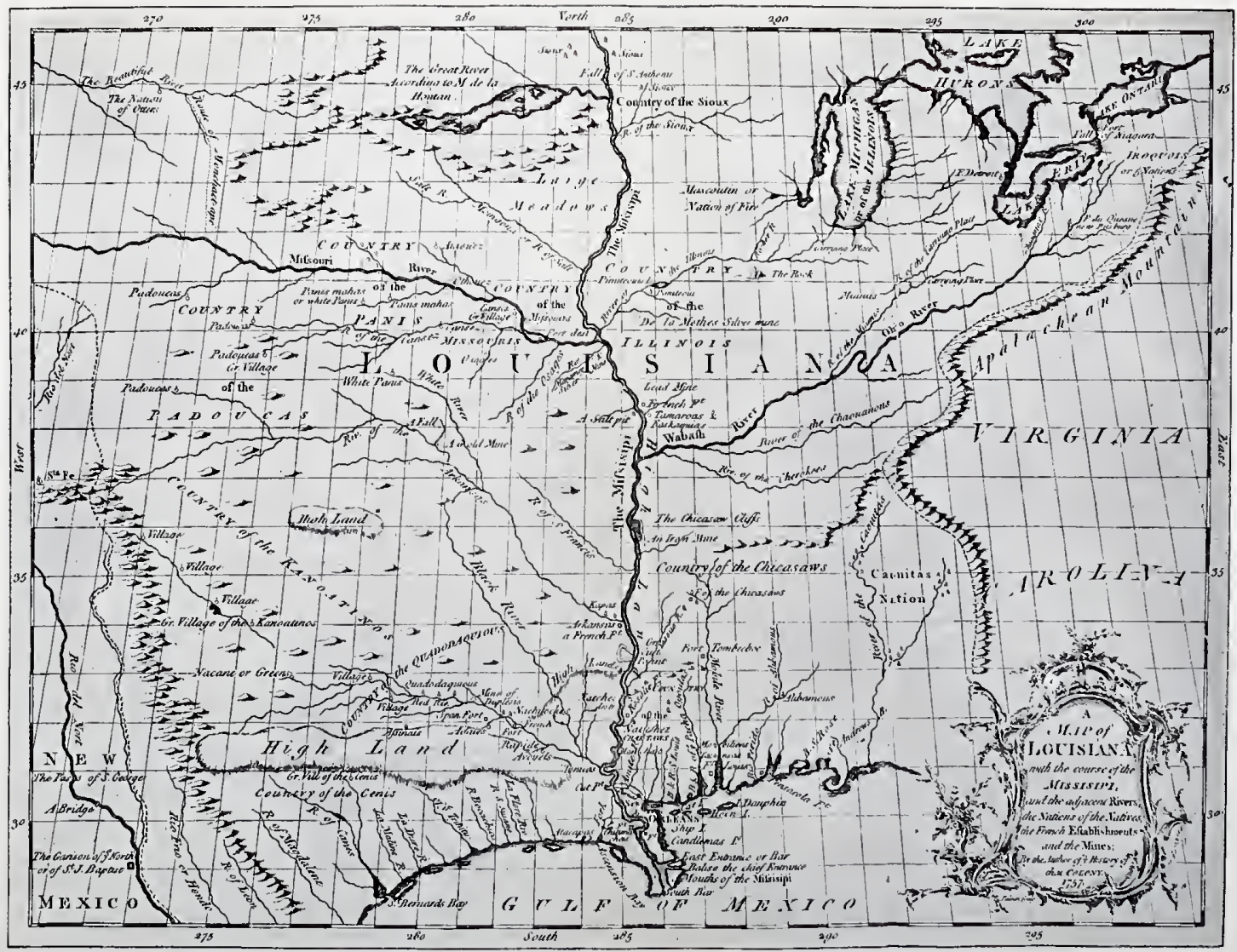





\section{I n $d e x$}

Abeikas Indians-293

Acacia Tree-222

Achechy-237

Adaies Indians-9; post of, 54

Agriculture, Indian-341

Aiaouez Indians-59, 62; 63; 66; 305

Alaron, Martin de-9, 10

Algonquins-93

Alder-226

Alibamous Indians-293

Alibamous River-135

Alligator-slave girl kills, 19; author kills large one, 22; description of, 253-255

Amite River-113

Ants-272; 273

Aplaches Indians-293

Apples, wild-212

Aquelou-Pissas Indians, 18; 297

Arkansas-German colonists there, $29 ; 88$

Arkansas Indians-mate with Canadians, 4 ; 57; 303

Arkansas River-reached by Tonti, 4 ; $112 ; 113$; 153-154

Armed-fish-276-277

Ascension Bay-114; 139

Ash-226

Aspen-226

Assinais Indians-5-9

Attakapas Indians-cannibals, 302

Avoyelles Indians-149; home of, 302-303

Ayac Shrub-226

Balers, Marquis of-9

Barataria-145

Barbel, description of -274

Barley-203

Baton Rouge-52; named after a cypress tree, 217

Bay of St. Bernard-3

Bay of St. Esprit-2

Bay of St. Louis-16;17; 114; lands around, 138

Bayou Choupic-17; 18

Bayou Goula-141

Bayou-Ogoulas Indians-52; 302

Bayou St. John-17; 18; 49; 52

Beans-cultivation in La., 204

Bears-132; 133; description of, 245-249; feast of, 324

Beavers-description of, 127-131

Bec-croche-261

Bees-271
Bienville-becomes Gov. Gen. of La., 10-11; founds New Orleans, 15 ; breeds hogs, 16 ; 28 ; 38 ;

defeats Natchez Indians, $39 ; 42 ; 49$; $71 ; 87 ; 88 ; 92: 93$; war against Chicasaws, 94-95; 109; returns to La., 186

Biloxi-11; 16; not suitable for settlement, 28; distress of German colonists, 29; country back of, $30 ; 47$; settlement destroyed, 137.

Birch Tree-231

Bishop (Bird) - 270

Blackbirds-268

Black River-113; land around it, 148; lands along, 151-154

Bon Homme-195

Bois-Briant-58

Bonita Fish-12

Bourgmont, Commander devoyage to Missouri and Kansas, 59-68; his journal, $69 ; 160 ; 305$

Bows-how made, 340

Buffalo-64; hunt by author, 122; $132 ; 134 ; 146 ; 147 ; 152$;

hunt in New Mexico, 155; hides and tallow, 155-156; 162, 178; description of, 240; Indian hunt, 240 ; feast of, 324

Burgo-Breaker (fish)-275

Burial customs-333-337

Butterflies-271

Buzzard-descsiption of, 258

Caouquias Indians-301

Caouitas Indians-293

Caddo Indians-151; 303

Cadillac, de la Motte-arrives in La., $5 ; 6 ; 8 ; 9$; death of, 10 ; his mine, 163

Calendar of Natchez-319

Calumet (Pipe of Peace) -35; feathers for, 258

Campeachy wood-183

Canadians-early voyagers to La., 4 ; at Dauphin Island, 16 ; at Mobile, 46; 58; 59; get salt, 157; Route to La., 161-163

Candlemas Islands-138

Cannes Brulee's-52

Canoe-how made, 69

Cantharadies-272

Canzas (see Kansas)

Cape Anthony-13

Cape Francois-11-13; 182 
Capuchins-51

Caranco-22

Cardinal-269

Carolina-population, IX; 47

Carp-17; 146; 274

Carrion-Crow-258

Carthaginians-practised scalping, 283

Caskaquias (see Kaskasia)

Cassine Shrub-228

Castin Bayou-113

Castine Mine-133

Catamounts-134; 144

Caterpillars-271

Catfish-description of, 274

Cat Island-16; 138

Cedar Trees-215; 225

Celoron, Capt. de- $93 ; 94$

Chacchi-Oumas Indians-300

Chactaw Indians (see Choctaw's)

Chaineau, M.-278

Chameleons-257

Champmelin, Commander-captures Pensacola XXIV; 104; 105

Chandeleur Islands-13

Chaouachas Indians-140; 301

Chaouanous River-162

Charleville, M. de-109; 110

Charlevoix-I; III; IV; XXV; XXVI; $24 ; 30$

Chateauguier-101

Chatkas Indians-295; language, 297

Chatots Indians-294.

Cherokees-293

Cherokee River-162

Chestnut Trees-214

Chicasaw Cliffs-133

Chicasaw Indians-46; murder French, 56-57; war with, 87-90; make peace, 94 ; country of, 137 ; destructive wars, 291 ; language, 297 ; destroy other tribes, 303304; fierce and arrogant, 332 .

Chitimachas Indians-18; war with, 71 ; 300 ; home of, 302

Choctaws-46;80;84;85; 113

Chopart, de-73; his death, 82

Choupic-276

Choupichoul (buck wheat)-156157

Clerac (Gascony) - 27

Climate-of Gulf Coast, III; VIII; severe weather, 36 ; at Mobile, 46; of the Miss. Valley, 57; of La., 107-108

Clothing of Indians-344-346

Cochineal-183
Cockle-Island-17, 138

Codfish-14

Cola-Pissas-18

Colbert-3

Coligni, Admiral de-2

Conchac Indians-293

Copper Mines-30, 145

Corbijeau-266

Cormorant, 259

Coroas Indians-300

Cooking, Indian-342

Corn-description of, 164-165; importance of 185 ; its cultivation in La., 202; feast of, 321 $322 ; 347$

Cotton-145; 158; how cultivated, 174-175; for export, 181

Cotton Tree-222

Coxe-account of Carolina, VI; XIII; 47

Cranes-22; 126; description of, 261

Crayfish-277

Creeper, bearded-232

Crocodile-253-255

Crows-268

Crozat-La. ceded to, 5; full storehouses, 8 ; transfers to West India Co., 10; 107

Cuba-13

Cushaws-cultivation in La., 206

Cypress Tree-IV; at Baton Rouge, $52 ; 216 ; 217$

id'Artaguette-28; 52; 88; 92

Dauphin Isle-13; $15 ; 45 ; 46 ; 49$; $101 ; 103$

d'Avion-23

Deer-64; white, 124 ; $132 ; 134 ; 144$; 152; hunt, 242-244; feast of, 319

Deer Oil-249

DeLaet-2

De Lisle-279

de Meuse-grant, 54

de Soto-2

de Ville, Father-26

Diodorus Siculus-his description of lands west of Africa, 281-282

Diseases-fatal to Indians-291; of Negroes, 359-360

Dove-266

Dragon flies-272

Draught (Bird) -263

Ducks-126; description of, 259-261

du Crenet-84

du Haye-198

Dumont (Historian) -I; V; VII; $\mathrm{XXV} ; 46 ; 56 ; 66 ; 113 ; 135$; historical memoirs, $187 ; 225$

Du Pratz-leaves La., 187 
du Tiffenet-88; 89

du Vernai-Paris, 52

Eagles-257

Eels-277

Egret-261

Elder Tree-231

Elephant-skeletons found in Ohio-290

Elk-64, 132, 134, 144

Elm-226

English-extent of American possessions, XIV; shipping, XVII; at English Turn, 47-51; on the Yazoo, $56 ; 57$; on the Miss. River, 140; tobacco trade, 199

English Turn (Reach) -47 ; 51; why its name, 139-140

Epidemic-13

Episingles Indians-93

Esquine-181, 233

Eye Inflammation-treatment for, 43

Exports-from La. to Islands, 182

Falcon-258

Feast of War-352-353

Feasts of Indians-320-322

Ferns-Maiden hair, 234-235

Fig Trees-210-211

Filberts-213

Fire, how made-340

Fireflies-272

Fish-plentiful in La., 274

Five Nations-294

Flamingo-22; 126; description of, 261

Flat root-235

Flaucourt, Loire de, 24

Flax-145

Fleury, Cardinal-187

Flies-271

Florida-French settle there, 2; Spanish attack them, 2;

French later attack Spanish, 2

Flowers-239

Flying Fish-12

Food of Indians-348-350

Fool-description of, 263

Forant, M. de-85

Fort Assumption-57; 93; 95

Fort Balise $-47 ; 48 ; 116 ; 118$; where built, 139

Fort Carolin (Fla.) -2

Fort Chartres-58

Fort Crevecoeur-3

Fort Louis-46; 294
Fort Mobile-88; 92

Fort Orleans-59; 61; 62; 69; 160

Fort Rosalie-23-24; 33; 34; 35

Fort St. Francis-92; 95

Fort St. John Baptist-6; 7; 9; 10

Fort St. Louis-136

Fox Indians-home of, 301

Foxes-251

French-shipping, XVII; in Fla., 2, 18 ; at Natchez, $32-33$; bad influence, 41 ; massacre at Natchez, 82 83; commerce with La., 177-182

Frigate (Bird) -263

Frogs-253

Fur trade-178

Gar fish-description of, 276-277

Gaillard-61-63; 65

Games-Indian, 347

Geese-wild, 127; 259

Gentilly-52

Germans-in La., 29

Gold-145; plentiful in Mexico, 150

Gourges, Dominque de-2; 8

Grapes-208-209

Grass Point-17

Great Sun-40; $42-43$

burial, 333-336

Green flies-272

Grigas Indians-298

Guenot-34

Gulf of Mexico Coast-1; northern boundary, 13;

description of land bordering, 135-137

Gypsum-124

Habitations of Indians-341

Hakluyt (Fla.) -2

Halcyon-description of, 263-264

Hatchet-bill-262

Havana-102

Hawks-258

Hedge-hog-253

Hennepin, Father-3

Herons-126; 261

Hemp-cultivation, $180 ; 238$

Hickory Trees-213

Horn Island-16

Hornbean Trees-226

Hops-177; 234

Howard, John-58

Hubert-planter, 20; 22; 24; 25

Hubert, Mme.-136; 167

Humming Bird-270

Hurons-93

Hurricane-30; $31 ; 32$

Huts-how made, 341 
Iapy, Commander-104

Iberville-made Gov. Gen. of La., 4; his death, $5 ; 8 ; 10$

Iberville River-113

Illinois-visited by Hennepin and LaSalle, 3 ; hurricane, $30 ; 57 ; 58$; $88 ; 162 ; 163$

Illinois Indians-66; home of, 300301

Illinois River-110

Indians-travel, 60-61; how to fight, 99-100; origin of, 279 ; descended from Europeans, 281

Indigo-cultivation and processing, 168-171; for export, 181; Dumont's method of making, 191-193

Iron-145

Iroquois-93; destructive wars of, 291

Ivy-ground, 237

Jamaica-13

Jesuits-51; 58

Kappas Indians-304

Kansas Indians-59; 60; 61; 62; $66 ; 68 ; 69 ; 305$

Kansas River-63; 64; 110; description of, 159

Kayemans-13

Kaskasia-58

Kaskasia Indians-301

King-fisher-description of, 263

la Chaise, Director Gen.-44; 45

Lake Borgne-17; 138

Lake Erie-111; 161

Lake Maurepas-17; 113

Lake Pontchartrain-17

Lake St. Louis-17; 46; 49; 52; $113 ; 135$

Lafourche (the Fork)-141

Language of Natchez-311

LaSalle-travels from Canada to the Gulf, 3; is killed on second trip, $4 ; 116$

Lavert-273

Laudonviere, René de-2

Laurel Trees-217

Laval, Father-XXIII; XXV

Lavigne, Sieur-18

Law, John-29

Lead-132; 145; 158; 163

LeBlanc-grant, $56 ; 88$

LeSueur-83

LeSueur, Bayou-116

Levans-29

Liart Trees-226
Lime Trees-226

Linarez, Duke of -7-9

Lion's Mouth (flower) 239

Lizards-257

Locust Tree-222

Longevity of Indians-329

L'Orient-29

Loubois, Lieut. de- $-83 ; 84$

Louis XIV-3; 5; 107

Louisiana-poor colonization, XXVI; named after Louis XIV, 3; names, 15 ; boundary of, 107 ; description of soil, 117-118; a fine country, 185; fertility of, 197

Luchereau, M. de-4

Magnolia Trees-218-219

Magpie-268

Maize-163-165; 202-203

Manchac River-111; 114

Mangrove-223

Maple Trees-220

Marameg Mine-158

Marameg River-58

Margat River-57; 93

Marriage customs-326-328

Massacre Island-Now Dauphin Isle, 13; how it was named, 14

Massacre of French at Natchez$73 ; 82$

Medicines-44; $45 ; 181 ; 215$

Medicine, Indian-26; 27; 43; 44

Mehane-22

Mexicans-descent from Chinese or Japanese, 284

Mexico-6; $7 ; 10$; home of ancient Natchez tribe, 279; natives kill themselves, 291

Mezieres, Marquis de-52

Miami River-111; 161; 162; 163

Michigamias Indians-304

Mines in Illinois-163; in La., 195196

Miragouine, Sieur-103

Mississippi River-lands of lower basin, VI; VII; commands continent, IX; navigation of, XI- XII; mouths of, XIII; reached by Hennepin, 3 ; 15; 18; 24; hurricane, 30 ; $47 ; 48 ; 49 ; 51$; inhabitants along, $52 ; 53 ; 55 ; 58 ; 59 ; 63 ; 107$; its names, 109 ; attempts to find source, 109; mouths of, 114-115; the passes, 117 ; 133 ; soil at mouth, 138-139; on east bank, 141-142; lands west of, $145 ; 161 ; 162 ; 163$; voyage to source by Indian, $289-290$ 
Mississippi Scheme-II; 58

Missionary-23

Missouri Indians- $59 ; 60 ; 66$; home of, 304-305

Missouri River-navigation of, XII; $60 ; 63 ; 69 ; 110$; description of, 159

Mobile-barren lands, XX; $9 ; 11$; birth place of La., $15 ; 45 ; 49 ; 89$; native of land, 135-136; fertility of animals and women, 136

Mobile Bay-114

Mobile Indians-294

Mobile River-Canadians settle on, $4-5 ; 46 ; 135$

Moingona River-110

Moncacht-apé, old wise man of Yazoo tribe-his voyages, 285290

Montplaisir, M. de-27

Montreal-59

Mosquitoes-description of, 272-273; how Indians fight, 333

Mulberry Trees-145; 158; for silk growing, 167-168; 212; feast of, 321

Muscadine Grapes-209

Mushroom-231

Myrtle Wax-tree-220

\section{Narvaez-1}

Natchez-goodness of the country, 20-21; commandment, 27-28; terrible storm, 30-32; settlement at, $38-39 ; 55-56$

Natchez Indians-DuPratz arrives among, 23-27; first war with French, 32-36; second war, 38$39 ; 55 ; 69$; council of war, $76-$ 77 ; 84; destroyed by French, 8687 ; 153; grow grain, 156 ; origin of, $279-280$; 297; home of, 298; power of, 299; description of social habits-birth and rearing children, 306-311; language, government, religion, 311-320

Natchitoches-French settle, 5; St. Denis at, 6; Spanish settle near, $8 ; 54$; quality of land, 148 ; silver there, 195

Natchitoches Indians-112; home of, 303

Negroes-revolt, 71; choice of for slaves, 357 ; how to handle, 361 ; odors of, 362

Nesunez, Pamphilo-1

New Orleans-V; health good, IX; settlement of, 11 ; founded, $15 ; 17$;
18; 22; physicians and surgeons of, 26 ; $30 ; 45$; 46 ; forts below, 48 ; description of, 49-52; harbor of, 52 ; 58 ; 71 ; climate, $108 ; 136$; nature of soil, 141; distance from Canada, 162

New Mexico-6; 54; 55; 112;

nature of land, 147; hunting there, 155

Niagara Falls-286

Nightingale-269

Nobility-Natchez, 328

North America-extent of, XV; its products, XVI

Oak Trees-IV; V; 223-225

Oats-203

Ohio River-navigation of, XII; 58; $111 ; 161 ; 162 ; 163$; skeleton of elephants found, 290

Ochre-23

Olivarez, Friar-9

Olive Trees-213

Orange Trees-212

Opelousas Indians-302

Opossum (wood-rat) -251

Orignaux-162

Osage Indians-59-60; 66; 304; 305

Osage River-159

Othouez Indians- $59 ; 60 ; 61 ; 62$; $66 ; 305$

Otters-253

Otter Indians-287-288

Ouachas Indians-140

Ouchitas Indains-former home of, 303

Ouachita River-113

Oumas Indians-52; 80; home of, 297

Ouse-Ogoulas Indians-300

Owls-268

Oysters-in La., 277; on trees in St. Domingo, 278

Paducah Indians- $59 ; 61 ; 62 ; 63 ; 65$; Customs and manners, 66-68 destructive wars of, 291; 305

Paillou, Major General-at N. O., $15 ; 18 ; 39$

Parroquets-266

Palmetto-231

Panimahas Indians- $59 ; 63 ; 66 ; 305$

Panis Indians-305

Partridges-144; 265

Pascagoulas River-114; 136

Pasca-Ogoulas Indians-15; 46; 295

Patassa (fish) - 276

Pawpaws-158; 210

Peach Trees-210-211

Pearl River-114 
Pelican-description of, 259

Pensacola-description of, XXIII; 2; Spanish settle, 8; captured by French, 100-105

Perdido River-104; 116; 135

Perrier-Gov. of La., $71 ; 73 ; 83 ; 85$; defeats Natchez Indians, 86-87; 153; leaves La., 186

Perrier de Salvert-72; 86

Persimmons-209

Peru-natives killed themselves, 291

Petits Ecores-52; 53

Pheasant-264

Phoenicians-ancestors of Natchez Indians, 283

Phenomenon-alarming, 30; at Natchez, 36-38; extraordinary, 70

Pigeons-description of, 266-267

Pike-276

Pilchard-14; description of, 276

Pimiteouis Indians-301

Pine-IV; for tar, 193-194; 217

Pipe of Peace-59;60;63;65; 258

Pitch-how to make, 194

Plaquemine Bayou-114

Plums-210

Pointe Coupeé-52; 53; 54

Pole Cat-252

Pope (Bird) -269

Poplar-222

Porcupine-253

Port de Paix-13

Puerto Rico-11

Potatoes (sweet) - cultivation in La., 204-205

Pottery-how made, 342

Provençals-in La., 29

Prud'homme Cliffs-93

Prud'homme River-57

Pumpkins-206

Quail-266

Quebec-3; 111

Rabbits-251

Raimond, Diego-6; 10

Rattle snake-cure for bite, 237; description of, 255

Rattle-snake herb-235-237

Red fish-14

Red River-54; 55; 112 ; nature of land, 148; 151

Red Shoe, Prince of Chactaws-95

Religion of Natchez-312

Rice-how grown, 165; how eaten, 166 ; in La., 204-205

Richebourg, Captain-101; 102
Ring-skate (fish) -276

Rio del Norte-6

Rochelle-author leaves, 11; returns to, 187

Rye-in Illinois, 162; 203

\section{Saffron-180}

Sagamity-348; 349

St. Anthony's Falls-109; 110

St. Augustin, Fla.-2

St. Bernard's Bay-116

St. Catherine's Creek-33; 34 ; $35 ; 38$

St. Come-Missionary, 71

St. Croix River-110

St. Denis-journey to Mexico, 6-11; 54 ; 104 ; popular with natives, 150

St. Domingo-4; $11 ; 13$; oysters on trees, 277

St. Francis River-57; lands around, 157-158; 112

St. Hilaire, Surgeon-42

St. Laurent-93; 94

St. Lawrence River-111; 161; 286

St. Louis Church-51

St. Louis River-3; 4 ; 8

St. Rose Isle-101; 102

St. Peter River-110

Sallee-58

Salmont, Com. Gen.-85

Salt-in lower La., 147; spring near Natchitoches, 149; mines, 153

Salt petre-147; 180

Samba-72

Santa Fé-112

Sarde (fish) -14

Sardine-276

Sarsaparilla-233

Sassafras-181; 220

Saw Bill-261

Scalping-283

Scotland-tobacco trade, 199

Scurvy-how to cure-360

Sea-Lark-263

Sea Snipe-263

Ship Island-16;28

Shrimp-277

Siam distemper-13

Silk-growing experiments, 167-168 cultivation possible, 176; worms, 271

Silver-145; 151; 158; 163; 195

Sioux Indians-109; home of, 301306

Skunk-252

Smallpox-fatal to Indians, 291

Snipe-266 
Spanish-claim La., 5; 54; 55; on west of La., colony, 146; near Natchitoches, 150; how they hunt in Mexico, 155; commerce with La., 183-184; attempt to settle Missouri, 305

Starlings-268

Stag-242

Spatula-description of, 261; 276

Spiders-description of, 257

Squirrels-252

Stink Wood Tree-226

Strawberries-238; feast of, 320

Stung Arm-79; 80;81

Stung Serpent-35; 40; death of, 335-336

\section{Sturgeon-14}

Sun of the Apple Villagenegotiates with the French, 73-78

Swallows-269

Swans-127; 162; 259

Sweet gum-181; 215

Tamarouas Indians-58; 162; $300 ; 301$

Tangipahoa River-113

Tar-how to make-193-194

Tassel-258

Tattooing-346

Tchefuncte River-113; 136

Teal-261

Temple, Indian-description of, 333

Tensas Indians-near Mobile, 294; language, 297; 300 ; former home of, 303

Tensas River-lands along, 152

Termites-273

Thioux Indians-299

Thomez Indians-294

Thorn, Passion-229-230

Thornback (fish) -14

Tigers-134; description of, 249250

Timber-for shipbuilding, 179

Tobacco-trade, XVII; plantation, 25 ; 145; 158; in Illinois, 163; how cultivated, 171-174; for export, 181; DuMont's description of cultivation, 187-191; advantages of La. cultivation, 197-198; British imports and exports, 199; worm, 271
Tombigbee-46; 89

Tonicas Indians-23; 27;44;80;

84 ; 85; language of, 298

Tonti, Chevalier de-3; 4

Topoussas Indians-300

Torture, Indian-354-355

Tortuga-13

Tooth-ache Tree-228

Tradewinds-12

Troniou-270

Turkeys, wild-120; 144; description of, 264 ; feast of, 324

Turkey Buzzard-258

Turtles-253

Ursuline Nuns-51

Vanilla-184

Vasquez de Aillon, Lucas-1

Vauban-46

Vaudreuil, Gov.--95; 96

Vinegar Tree-227

Virginia-58

Wabash River-110; 111; 161; $162 ; 163$

Walnut Tree-158; 213

War-with Natchez Indians, 32-36; 38-39; causes of Indian wars, 9697 ; how they fight, 350 ; war feast, 352-353

Wasps-271

Water-hen-262

Water Melons-how grown, 166; cultivation of in La., 206-207; feast of, 321

Wax-from Wax Tree, 220-222

Wax Tree-176; 220-222

West India Company-Takes over La., 10; sends colonists, 11; 18; 32 ; 44 ; gives up colony, 85

Wheat-145; in Illinois, 162; in La., 203

White Apple Village-33; 39; demanded by French, 73

Whortle-berries-212

Wild Cat-251

Wild Geese—22; 259

Wild Turkey-description of, 264 (see turkey)

Willow Tree-226

Wolves-134; 144; kill buffaloes, 156; description of, $244-245$ 
Women-"fruitful" in La., 185

Woodcock-266

Wood-pecker-description of, 268269

Wood-Rat-251

Wren-258
Yapon Shrub-228

Yaws-359

Yazoo Indians-56; kill the garrison at their Post, $83 ; 300$

Yazoo River-56; 112

Ydalgo, Friar-5; 7; 9

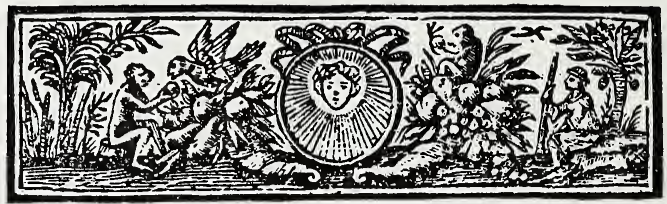








(i) . . ( 


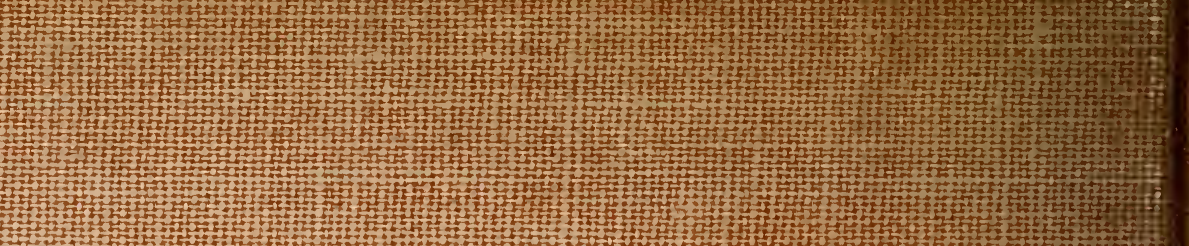

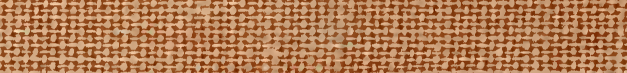
W

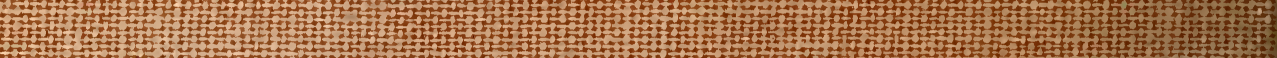

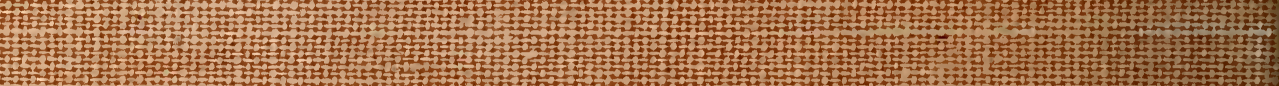

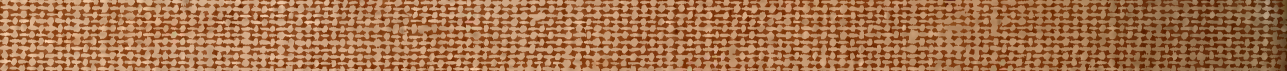
T

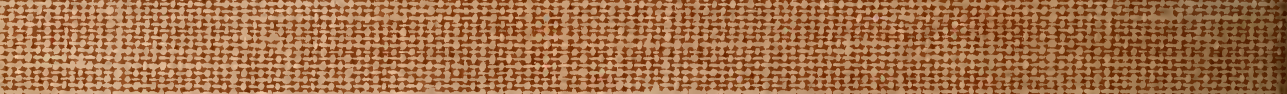
H

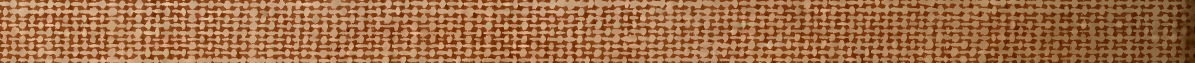

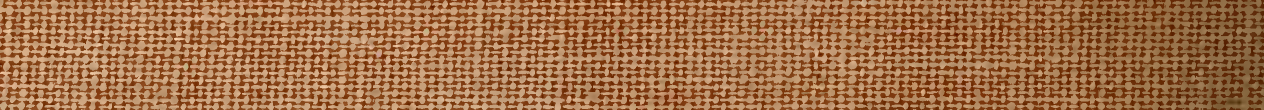

